Дальневосточный федеральный университет

Н.Ю. Чеснокова,

Ю.В. Приходько,

Т.К. Каленик

\title{
АНТОЦИАНЫ \\ В ПИЩЕВЫХ ТЕХНОЛОГИЯХ \\ И БИОТЕХНОЛОГИЯХ
}

Монография

Владивосток

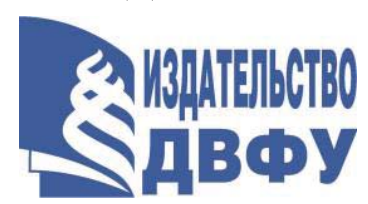

2021 
ББК $30.16+42.3$

Ч-51

\section{Pеценизенты:}

Т.М. Бойцова, д-р техн. наук, профессор кафедры

«Технология продуктов питания» Дальневосточного государственного технического рыбохозяйственного университета;

Н.Ф. Кушнерова, д-р биол. наук, профессор, заведующая лабораторией биохимии Тихоокеанского океанологического института им. В.И. Ильичева ДВО РАН.

\section{Чеснокова, Наталья Юрьевна.}

Ч-51 Антоцианы в пищевых технологиях и биотехнологиях : монография / Н.Ю. Чеснокова, Ю.В. Приходько, Т.К. Каленик. - Владивосток : Издательство Дальневосточного федерального университета, 2021.146 с. : ил.

ISBN 978-5-7444-5154-7.

DOI https://doi.org/10.24866/7444-5154-7.

В работе впервые обоснованы биотехнологии получения антоциановых красителей из ягод Дальневосточного региона и продуктов их переработки выжимок с максимальным извлечением антоцианов и сохранением ими выраженной биологической активности. Подобраны биобезопасные экстрагенты полисахариды и белки для извлечения антоцианов из ягодного сырья, показана целесообразность и оптимизированы условия использования ультразвука, позволяющие сокращать время и увеличивать полноту экстрагирования антоцианов. Научно обоснованы рациональные параметры биотехнологий функциональных кондитерских изделий с использованием антоциановых красителей, содержащих комплексы биологически активных веществ. Впервые показано преимущество использования комплексов антоцианов и анионных полисахаридов для создания смарт упаковки.

Книга представляет интерес в первую очередь для работников пищевой промышленности и студентов высших учебных заведений.

Ил. 72, табл. 39, библ. 82.

Ключевые слова: ягодное сырье Дальневосточного региона, антоцианы, антоциановый краситель, комплексы антоцианов и биополимеров, функциональные продукты питания, смарт упаковка.

$$
\begin{aligned}
& \text { УДК 664.143.022.33:634.7(571.6):547.918 } \\
& \text { ББК 30.16+42.3 }
\end{aligned}
$$




\section{СОДЕРЖАНИЕ}

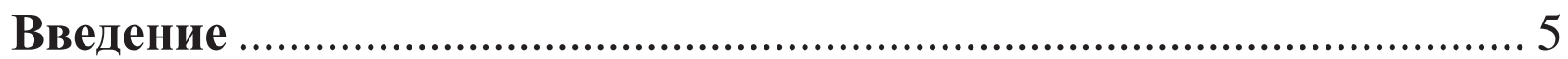

ГЛава 1. БИОЛОГИЧЕСКАЯ АКТИВНОСТЬ АНТОЦИАНОВ

ЯГОД ДАЛЬНЕВОСТОЧНОГО РЕГИОНА .................................. 8

ГЛава 2. ТЕХНОЛОГИИ ВЫДЕЛЕНИЯ АНТОЦИАНОВ

ИЗ ЯГОД ДАЛЬНЕВОСТОЧНОГО РЕГИОНА ................................ 13

2.1. Факторы, определяющие извлечение антоцианов

из ягодного сырья .............................................................................. 13

2.2. Использование аскорбиновой кислоты в качестве экстрагента для выделения антоцианов ................................................................... 16

2.3. Использование полисахаридов в качестве эффективных экстрагентов для выделения антоцианов из ягодного сырья ........... 20 2.4. Использование белков в качестве эффективных экстрагентов для выделения антоцианов из ягодного сырья ........... 27

2.4.1. Использование желатина для экстрагирования антоцианов из ягодного сырья......................................................... 28

2.4.2. Использование яичного альбумина и БСА для экстрагирования антоцианов из ягодного сырья ............................. 31

2.5. Оптимизация технологий выделения антоцианов из ягодного сырья Дальневосточного региона...................................... 34 2.6. Оптимизация технологий получения антоцианов из вторичных продуктов переработки ягодного сырья....................... 45 2.7. Идентификация антоцианидинов, содержащихся в растворах антоцианов, полученных при разных условиях экстрагирования 51

ГЛАВа 3. ТЕХНОЛОГИИ ПОЛУЧЕНИЯ И ПОКАЗАТЕЛИ КАЧЕСТВА НАТУРАЛЬНЫХ АНТОЦИАНОВЫХ

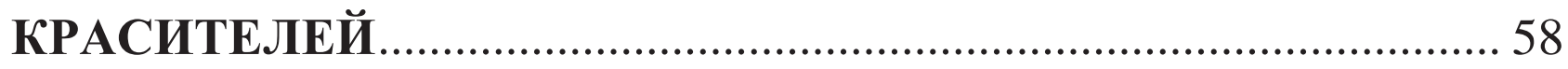




\section{ГЛава 4. ИСПОЛЬЗОВАНИЕ АНТОЦИАНОВОГО \\ КРАСИТЕЛЯ В ПИЩЕВЫХ ТЕХНОЛОГИЯХ}

И БИОТЕХНОЛОГИЯХ............................................................... 73

4.1. Использование антоцианового красителя

в технологии кондитерских изделий ........................................ 73

4.1.1. Использования антоцианового красителя

в производстве функциональных сахаристых кондитерских изделий ........................................................... 73

4.1.2. Использования антоцианового красителя в производстве функциональных пастильных кондитерских изделий .......................................................... 78

4.1.3. Использования антоцианового красителя в производстве масложировых композиций отделочных полуфабрикатов ...................................................................... 84

4.1.3.1. Применение окрашенного антоциансодержащего структурообразователя в производстве сливочных кремов.. 84 4.1.3.2. Применение концентрированного антоцианового красителя в производстве сливочных кремов....................... 91

4.1.4. Использование антоцианов в производстве мучных кондитерских изделий .......................................................... 95

4.1.5. Оценка качества и безопасности функциональных кондитерских изделий ............................................................. 100

4.2. Использование антоцианов для создания смарт упаковки ..... 107 Заключение ........................................................................... 130

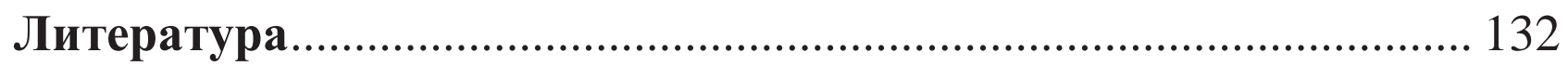

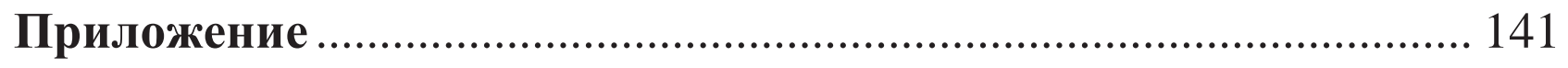




\section{Введение}

Одним из основных направлений продовольственной политики Российской Федерации в настоящее время является осуществление комплекса мероприятий, обеспечивающих потребности населения в здоровом питании, за счет расширения ассортимента продуктов функционального назначения. Наиболее перспективным направлением развития индустрии функциональных продуктов питания является использование в их производстве не только биологически активных добавок, но и добавок из традиционного и нетрадиционного растительного сырья. Поэтому, задачей, стоящей перед современной пищевой промышленностью, является производство экологически чистой и обогащенной пищевой продукции за счет использования традиционного и нетрадиционного плодово-ягодного районированного сырья, а также применение отходов его переработки.

Одним из путей решения проблемы производства экологически чистой и функциональной пищевой продукции является создание и использование в технологии производства продуктов питания безопасных натуральных пищевых красителей. Главные критерии, определяющие качество красителей, это в первую очередь безопасность, красящая способность, растворимость и экологическая эффективность. Они должны обеспечивать яркий, равномерный и стойкий окрас всего продукта и не причинять вред организму человека.

Для окрашивания продуктов питания пищевая промышленность в основном использует синтетические красители. Синтетические красители имеют яркую устойчивую окраску, просты в применении, однако, могут вызывать аллергические реакции или оказывать патологическое влияние на организм человека. Поэтому, в настоящее время возрастает интерес к использованию красителей природного происхождения. В отличие от многих синтетических, натуральные красители нетоксичны и придают продукту естественный цвет. Кроме того, многие из них обладают высокой антиоксидантной активностью [17, 27, 63, 64].

Дальний Восток России располагает доступной сырьевой базой для получения натуральных красителей и создания на их основе 
функциональных и специализированных продуктов питания. В связи с этим становится актуальным конструирование пищевых систем с использованием натуральных антоциановых красителей, полученных из ягодного сырья Дальневосточного региона и обладающих выраженной биологической активностью, поскольку в своем составе, кроме красящих компонентов они содержат полезные биологически активные вещества [3]. Витамины, гликозиды, органические кислоты, ароматические вещества, микроэлементы, содержащиеся в антоцианах, обладают множеством полезных свойств - снижают уровень холестерина, препятствуют образованию тромбов, повышают эластичность сосудов, ускоряют заживление ран, благоприятно влияют на зрение, способствуют профилактике онкологических заболевании [11, 31, 41, 44, 48, 50, 61, 79, 81].

Антоцианы представляют собой моно- и дигликозиды распадающиеся при гидролизе на сахар и агликоны, называемые антоцианидинами (пеларгонидин, цианидин, дельфинидин и др.) [17, 23]. В зависимости от присутствующих антоцианидинов антоцианы могут давать красную, фиолетовую, синюю окраску.

Однако цветовые составы на основе антоцианов имеют некоторые ограничения. Кроме того, извлечение антоцианов из природных источников, из-за их плохой стабильности, не всегда легко и осуществимо для применения в промышленных масштабах. Поэтому, исследования, посвященные усовершенствованию технологий выделения антоцианов из растительного сырья, их стабилизации и возможности их использования в пищевой промышленности является своевременными и актуальными. Представляемая монография является обобщением публикаций авторов по исследованию условий и технологий выделения антоцианов из ягодного сырья, а также возможности их использования для создания функциональных продуктов питания и биобезопасных упаковочных материалов.

Целью настоящей работы является изучение состава, свойств, технологий выделения антоцианов из ягодного сырья Дальневосточного региона и использование их в производстве пищевой продукции и смарт упаковки. При этом были решены следующие задачи: 
- исследована биологическая активность антоцианов ягод Дальневосточного региона;

- обоснованы оптимальные технологии получения антоцианов из растительного сырья;

- разработаны биотехнологии натуральных антоциановых красителей:

- обосновано использование антоцианов в технологии пищевых продуктов и смарт упаковочных материалов. 


\section{ГЛава 1. БИОЛОГИЧЕСКАЯ АКТИВНОСТЬ АНТОЦИАНОВ ЯГОД ДАЛЬНЕВОСТОЧНОГО РЕГИОНА}

Антоцианы - гликозиды, относящиеся к флавоноидам. Молекула антоцианов имеет в своем составе C15-углеродный скелет, два бензольных кольца А и В, соединенных С3-фрагментом, который с атомом кислорода образует гамма-пироновое кольцо. Все антоцианы содержат в гетероциклическом кольце четырехвалентный кислород (оксоний), придающий молекуле антоцианов положительный заряд [47]. При гидролизе антоцианы распадаются на углеводы (галактоза, глюкоза, рамноза и др.) и агликоны, представленные антоцианидами. Общая формула антоцианов приведена на рисунке 1.1 .

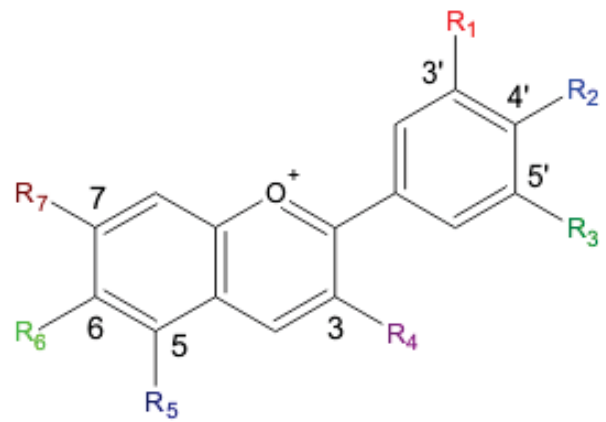

Рис. 1.1. Общая формула антоцианов

Антоцианы являются самой значимой группой водорастворимых пигментов растений [55, 59], ответственных за красный, фиолетовый и голубые цвета различных фруктов, овощей и цветов. Антоцианы можно обнаружить практически во всех высших растениях $[45,70]$.

Источниками получения антоцианов является растительное сырье (лепестки цветов, ягоды, плоды, овощи и т.д.), а также продукты переработки ягодного сырья - выжимки. Наиболее богаты антоцианами такие растения, как черника, голубика, клюква, жимолость, брусника, ежевика, чёрная смородина, черноплодная рябина, калина, малина, вишня, темные сорта винограда, красная капуста, чёрный рис, и др. [24, 49, 55, 76]. 
Содержание антоцианов существенно зависит от объекта выделения. УФ-спектры поглощения антоцианов, выделенных из доступного культивированного и дикорастущего ягодного сырья Дальневосточного региона - жимолости (Lonicera tatarica L.), черной смородины (Ríbes nígrum), брусники (Vaccinium vitis-idaea L.) и калины (Viburnum opulus) приведены на рисунке 1.2.

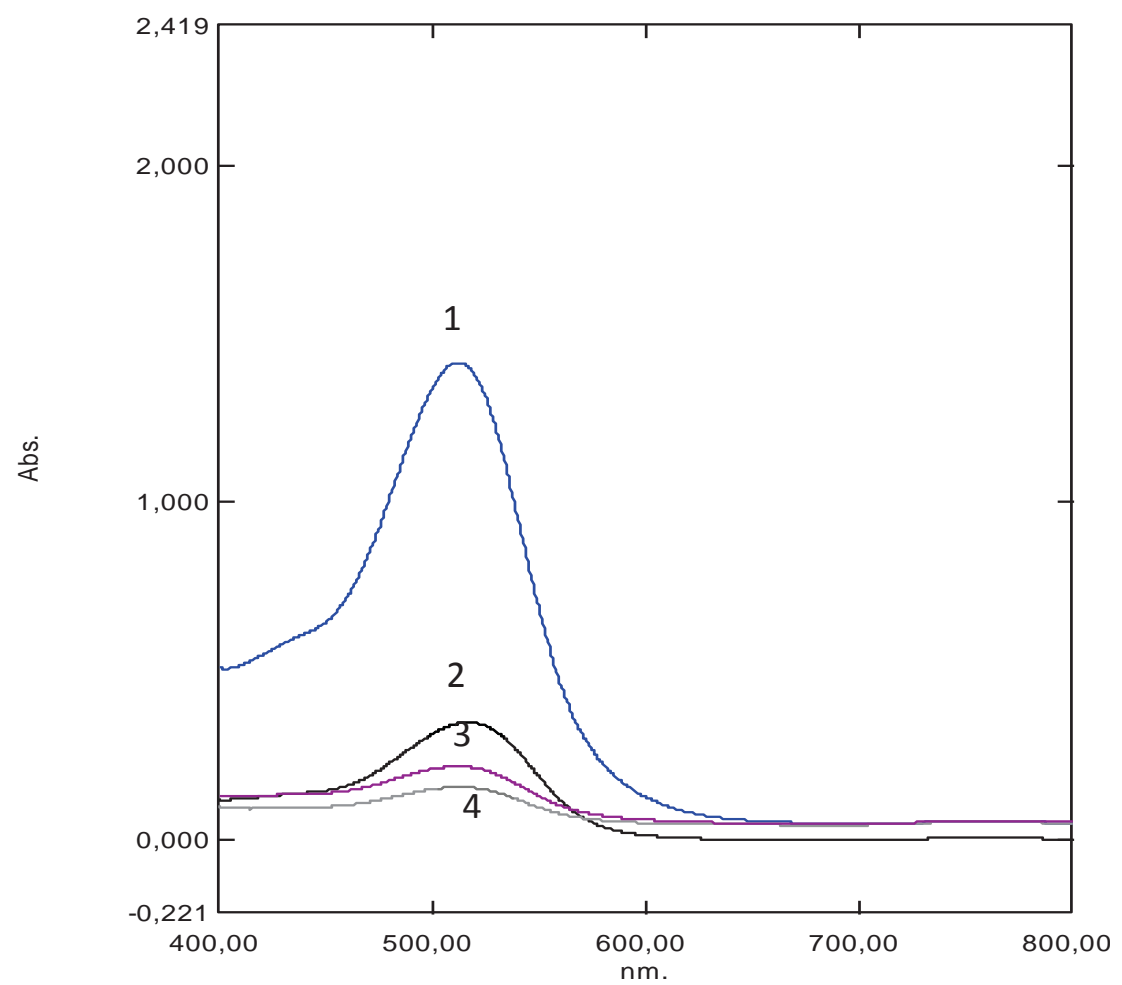

Puc. 1.2. УФ-спектры поглощения экстрактов антоцианов жимолости (1), черной смородины (2), брусники (3), калины (4)

УФ-спектры показывают, что независимо от используемого ягодного сырья максимум поглощения наблюдается при длине волны 515 нм. Наибольшим значением оптической плотности обладает экстракт антоцианов, выделенных из жимолости. Максимальное значение оптической плотности экстракта антоцианов жимолости составляет 1,48. Спектры поглощения экстрактов антоцианов черной смородины, брусники и калины значительно ниже. Максимальное значение оптической плотности составляет $0,35,0,25$ и 0,15 , соответственно.

Содержание антоцианов в ягодах жимолости, черной смородины, брусники и калины представлено в таблице 1.1 . 
Таблица 1.1

\section{Содержание антоцианов в ягодном сырье}

\section{Дальневосточного региона}

\begin{tabular}{|l|c|}
\hline \multicolumn{1}{|c|}{ Наименование сырья } & Содержание антоцианов, мг/см ${ }^{3}$ \\
\hline Жимолость & $3,15 \pm 0,10$ \\
\hline Черная смородина & $2,95 \pm 0,14$ \\
\hline Брусника & $1,13 \pm 0,26$ \\
\hline Калина & $0,30 \pm 0,08$ \\
\hline
\end{tabular}

ИК-спектры экстрактов антоцианов, выделенных из ягод черной смородины, калины, жимолости и брусники представлены на рисунках 1.3-1.6.

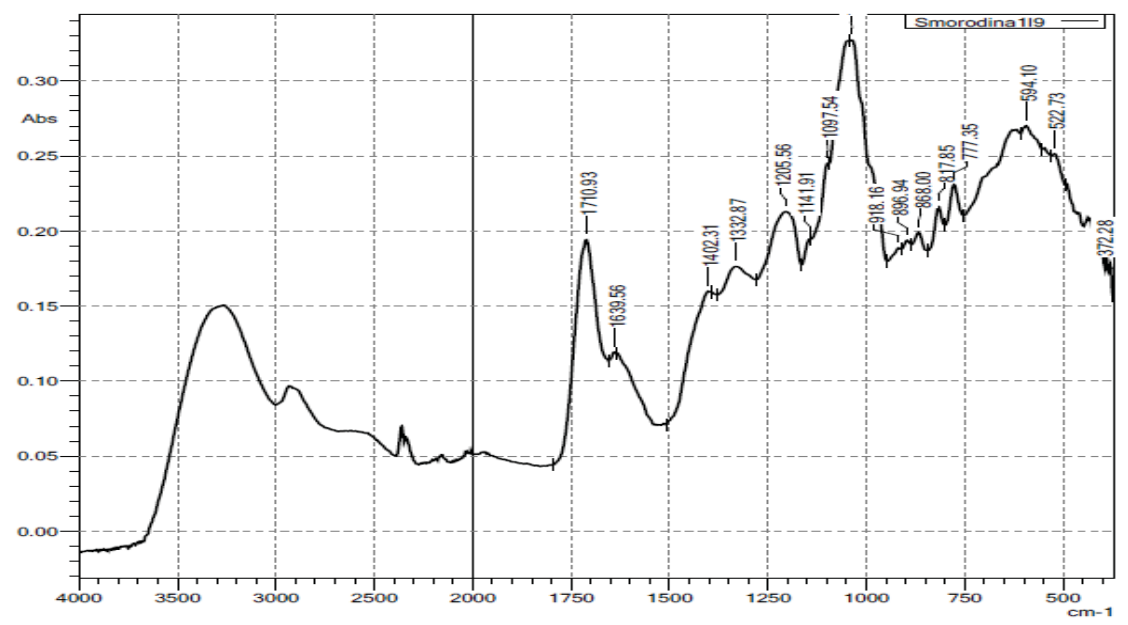

Puc. 1.3. ИК-спектр экстракта антоцианов черной смородины

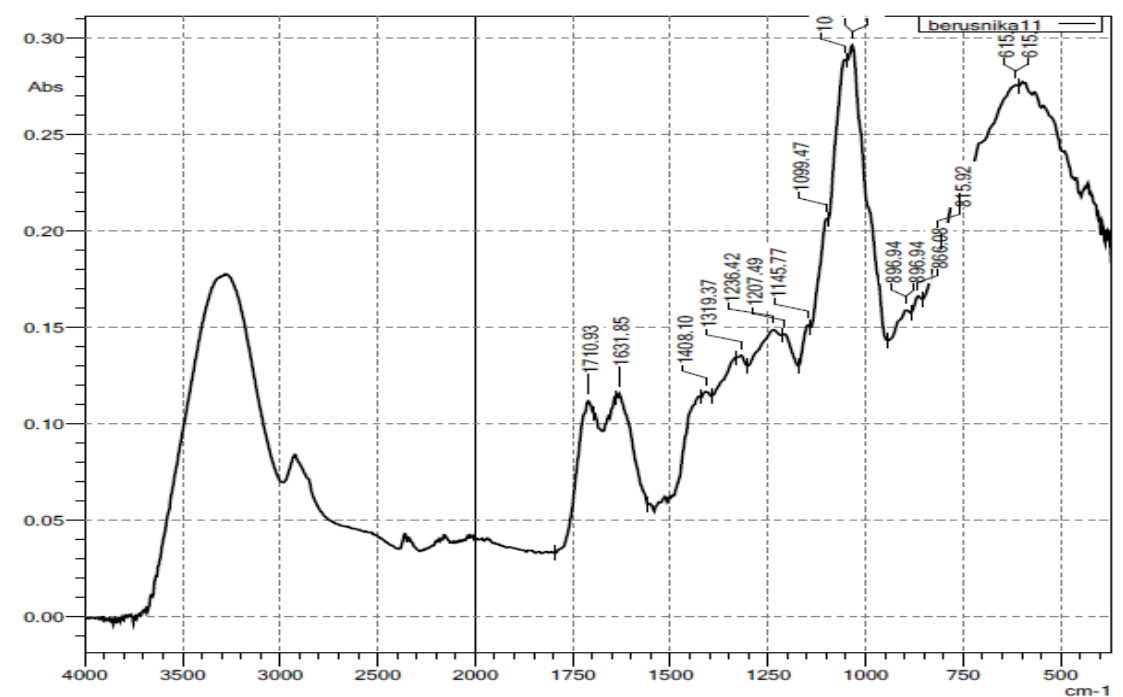

Puc. 1.4. ИК-спектр экстракта антоцианов брусники 


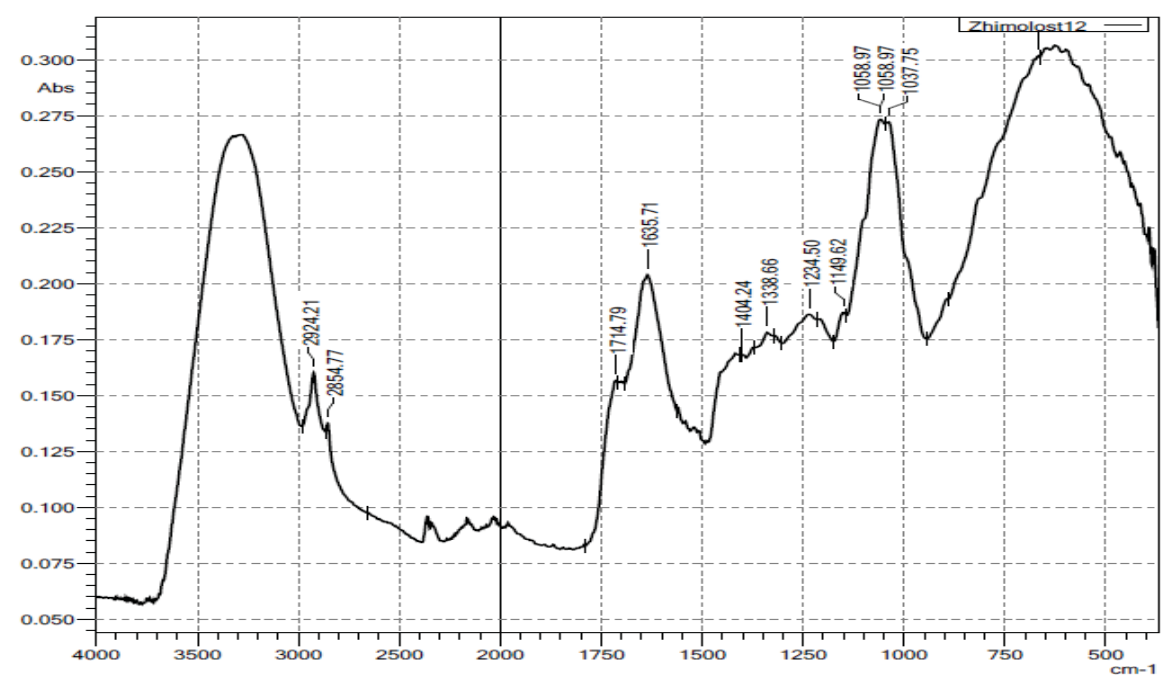

Puc.1.5. ИК-спектр экстракта антоцианов жимолости

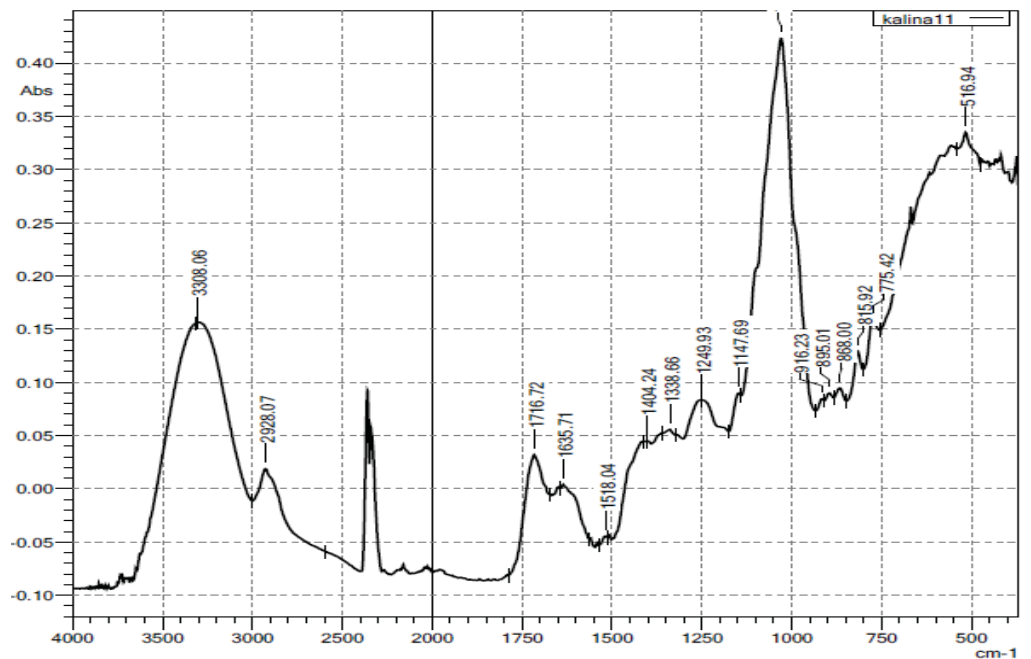

Puc. 1.6. ИК-спектр экстракта антоцианов калины

ИК-спектры антоцианов ягод идентичны и имеют сильные полосы поглощения при 1710-1716 $\mathrm{cm}^{-1}$ и 1631-1643 см-1, что соответствует валентным колебаниям $\mathrm{C}=\mathrm{O}$ и $\mathrm{C}=\mathrm{C}$ групп ароматического кольца [62, 65]. Полосы при 1027-1049 см ${ }^{-1}$ относятся к С-Н группам ароматического кольца $[60,71,82]$. Фенольные гидроксилы агликона определяются в области 3300-2700 $\mathrm{cm}^{-1}$. 0Н-группы углеводных заместителей проявляются в области 3600-3300 $\mathrm{cm}^{-1}$.

Приведенные ИК-спектры ягод практически идентичны, однако, наблюдаются различия в интенсивности полос поглощения и площади под спектральными кривыми, что является строго специфичным для каждого вида ягодного сырья. 
Значения антирадикальной активности антоцианов, выделенных из ягод жимолости, черной смородины, брусники и калины представлены в таблице 1.2 .

Таблийа 1.2

Значения антирадикальной активности антоцианов, выделенных из ягодного сырья

\begin{tabular}{|l|c|c|}
\hline $\begin{array}{c}\text { Источник выделения } \\
\text { антоцианов }\end{array}$ & $\mathrm{Ec}_{50}, \%$ & $\begin{array}{c}\text { AОА в перерасчете Trolox } \\
\text { эквивалент, мM }\end{array}$ \\
\hline Черная смородина & $0,92 \pm 0,04$ & $1,30 \pm 0,04$ \\
\hline Жимолость & $1,10 \pm 0,05$ & $0,76 \pm 0,05$ \\
\hline Калины & $1,21 \pm 0,03$ & $0,75 \pm 0,03$ \\
\hline Брусника & $1,60 \pm 0,03$ & $0,43 \pm 0,03$ \\
\hline
\end{tabular}

Результаты таблицы 1.2 показывают, что ягодное сырье Дальневосточного региона обладает антирадикальной активностью. Наибольший показатель антирадикальной активности у антоцианов, выделенных из черной смородины, он составляет 1,30 мМ в перерасчете на Trolox эквивалент. Значения показателя антирадикальной активности антоцианов, выделенных из ягод жимолости, калины и брусники значительно ниже и составляют 0,76, 0,75 и 0,43 мМ в перерасчете на Trolox эквивалент, соответственно.

\section{Выводы по главе 1}

1. Ягодное сырье Дальневосточного региона - жимолость, черная смородина, брусника и калина является источником антоцианов.

2. Антоцианы, выделенные из ягод Дальневосточного региона, обладают выраженной антирадикальной активностью. 


\section{ГЛава 2. ТЕХНОЛОГИИ ВЫДЕЛЕНИЯ АНТОЦИАНОВ ИЗ ЯГОД ДАЛЬНЕВОСТОЧНОГО РЕГИОНА}

В настоящее время особый интерес у исследователей вызывает усовершенствование и разработка новых способов экстрагирования антоцианов из растительного сырья. Кроме того, выбор подходящих технологий выделения с учетом оптимальных сочетаний экстракционных факторов для получения природных антоциановых красителей имеет решающее значение для успеха процесса их производства.

Основными способами выделения антоцианов из растительного сырья является тепловая экстракция, экстракция катализаторомрастворителем, ультразвуковая экстракция и т.д.

\section{1. Факторы, определяющие извлечение антоцианов из ягодного сырья}

В данном разделе рассмотрено пять способов выделения антоцианов из ягодного сырья. Это тепловая экстракции антоцианов при температурах 25, 75 и $100{ }^{\circ} \mathrm{C}$ в течение 60 мин, кислотный гидролиз 0,1 н HCl и экстрагирование 0,05 мас. \% каппа-каррагинаном.

Зависимость значений оптической плотности растворов антоцианов от природы экстрагента и условий выделения представлены на рисунке 2.1.

Полученные данные показывают, что максимум поглощения растворов антоцианов наблюдается при длине волны 515 нм независимо от условий его выделения и вида используемого экстрагента.

Минимальными значениями оптической плотности обладает раствор антоцианов, полученный в результате экстрагирования водой при комнатной температуре $\left(25^{\circ} \mathrm{C}\right)$. Значение оптической плотности при данном способе выделения составляет 0,36. Экстрагирование водным раствором при температуре $70{ }^{\circ} \mathrm{C}$ в течение 60 мин приводит к увеличению значений оптической плотности раствора антоцианов. Степень извлечения увеличивается в 1,4 раза. 

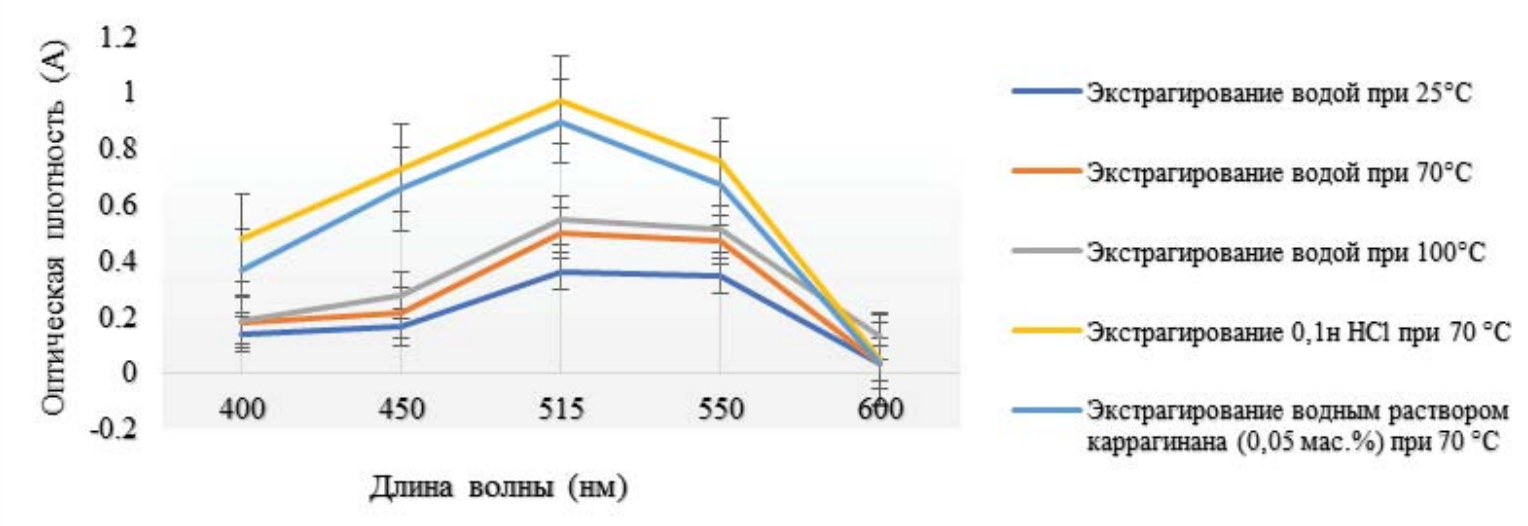

Puc. 2.1. Зависимость значений оптической плотности

растворов антоцианов черной смородины

от природы экстрагента и условий выделения

Дальнейшее повышение температуры экстрагирования до $100{ }^{\circ} \mathrm{C}$ в течение 5 мин незначительно увеличивает значение оптической плотности растворов. Значения оптической плотности растворов антоцианов, выделенных при $70{ }^{\circ} \mathrm{C}$ и при $100{ }^{\circ} \mathrm{C}$ составляют 0,49 и 0,54, соответственно. Таким образом, наиболее благоприятная температура для экстрагирования антоцианов была $70{ }^{\circ} \mathrm{C}$, поскольку, при данных условиях за счет инактивации окислительных ферментов, практически не происходит термической деградации антоцианов, что приводит к стабилизации их окраски и сохранению в их растворах биологически активных соединений [67].

Наибольшей экстрагирующей способностью обладают растворы 0,1 н соляной кислоты и 0,05 мас. \% каппа-каррагинана. Значение оптической плотности антоцианов, выделенных водным раствором каппа-каррагинана, составляет 0,89 .

Максимальное значение оптической плотности при извлечении антоцианов 0,1 н соляной кислотой составляет 0,97. Известно [52], что использование кислот для извлечения антоцианов оказывает существенное влияние на экстрагирующую способность, поскольку при кислых значениях рН пигмент достаточно стабилен. Полученные результаты не противоречат данному заключению. 
В связи с тем, что на интенсивность окраски, а также стабильность антоцианов существенно влияет реакция среды [22, 72] была исследована зависимость изменения $\mathrm{pH}$ от условий выделения и присутствия в среде экстрагентов разной природы. Значения $\mathrm{pH}$ растворов антоцианов, выделенных различными способами представлены на рисунке 2.2.

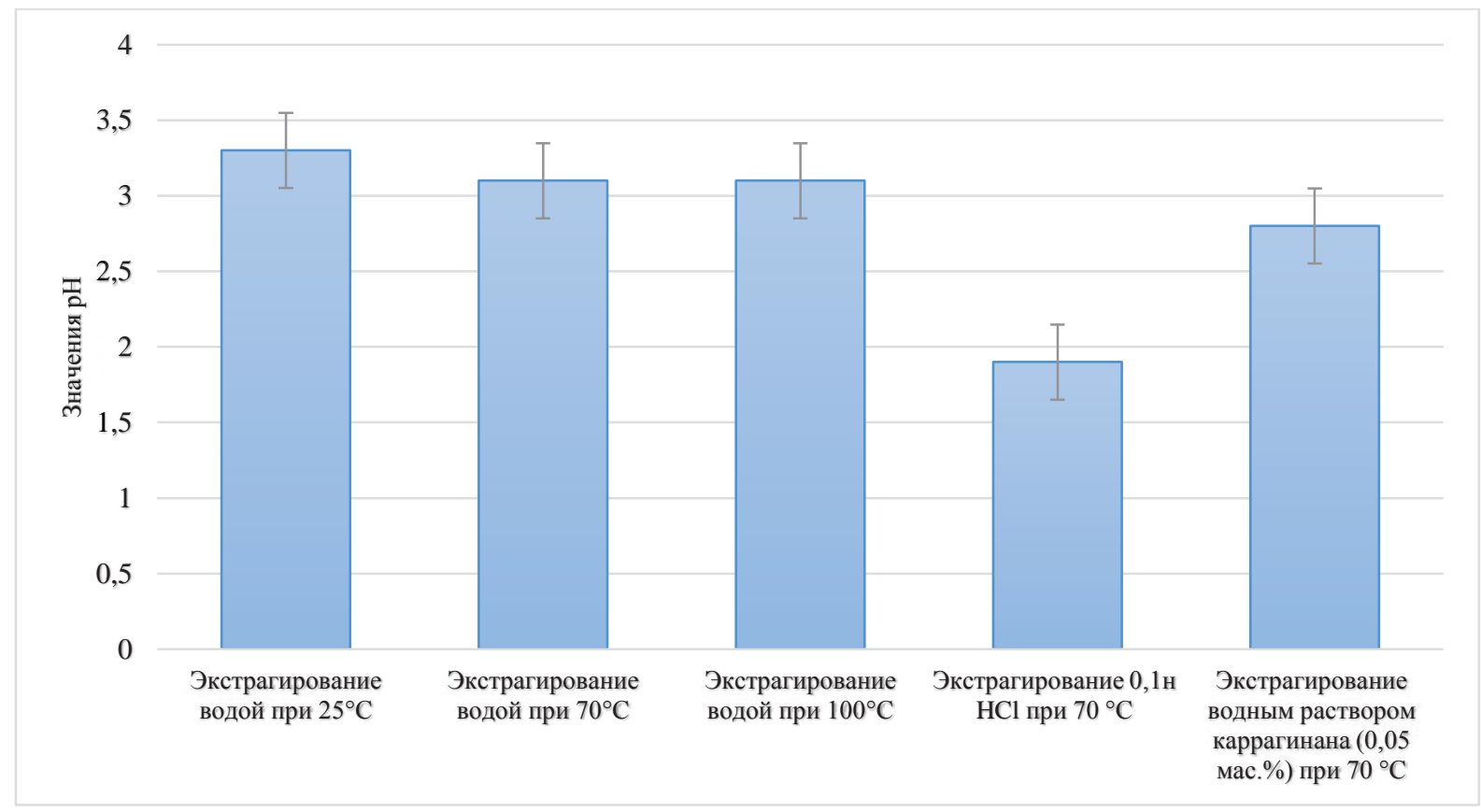

Рuc. 2.2. Значения $\mathrm{pH}$ растворов антоцианов, выделенных водным, водно-полисахаридным растворами и раствором 0,1 н соляной кислоты

Из полученных результатов видно, что значения $\mathrm{pH}$ растворов антоцианов, экстрагированных водой при температурах 25,70 и $100{ }^{\circ} \mathrm{C}$ колеблются в узких пределах 3,1-3,3 и не зависят от температуры выделения.

Минимальное значение $\mathrm{pH}-1,9$ имеет раствор антоцианов, выделенный в присутствии 0,1 н раствора соляной кислоты. Использование в качестве экстрагента 0,05 мас. \% раствор каппакаррагинана также понижает $\mathrm{pH}$ до 2,8, поскольку каррагинаны являются анионными полисахаридами и обладают свойствами слабых кислот. 
Сопоставление изменений значений оптической плотности в зависимости от природы экстрагента и условий выделения (рисунок 2.1) со значениями $\mathrm{pH}$ растворов показало, что при низких значениях $\mathrm{pH}$ извлечение антоцианов в раствор наибольшее. В кислой среде $(\mathrm{pH} \leq 2)$ антоцианы устойчивы к воздействию внешних факторов, так как они существуют в виде ярко красного катиона флавилиума, поэтому при данных значениях $\mathrm{pH}$ они стабильны [52]. При повышении $\mathrm{pH}$ от 2 до 6 происходит образование бесцветных псевдооснования (карбинола) и халкона, что приводит к распаду антоцианов и, соответственно, к падению интенсивности их экстрагирования.

Таким образом, существенное влияние на экстрагирование антоцианов оказывает природа экстрагента и реакция среды.

\section{2. Использование аскорбиновой кислоты в качестве экстрагента для выделения антоцианов}

Ввиду того, что при кислых значениях рН в присутствии кислот антоцианы достаточно стабильны, в данном разделе показано использование аскорбиновой кислоты в качестве экстрагента для выделения антоцианов из ягодного сырья.

Зависимости выхода антоцианов от содержания аскорбиновой кислоты в растворе представлены на рисунке 2.3.

Из представленных результатов видно, что выделение антоцианов из ягодного сырья зависит от присутствия в растворе аскорбиновой кислоты. Без ее добавления содержание антоцианов в растворе составляет 0,85 мг/см . Использование 0,2-1 \% раствора аскорбиновой кислоты в качестве экстрагента приводит к росту выхода антоцианов из ягодного сырья (рисунок 2.3 а). Добавление $1 \%$ раствора аскорбиновой кислоты в систему увеличивает степень извлечения антоцианов в 1,4 раза. Дальнейшее увеличение количества аскорбиновой кислоты в растворе до 2-10 \% (рисунок 2.3 б) приводит к незначительному повышению выхода антоцианов в раствор. Степень их извлечения повышается в 1,4-1,6 раз, соответственно. 


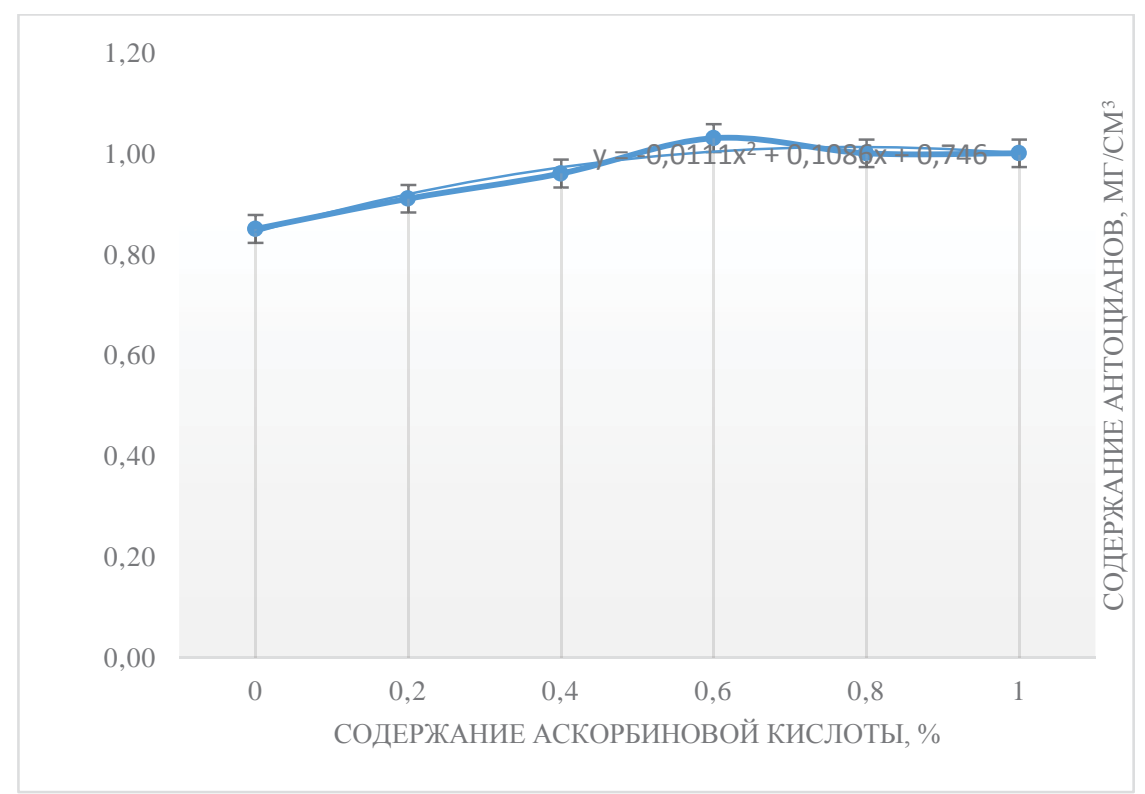

a)

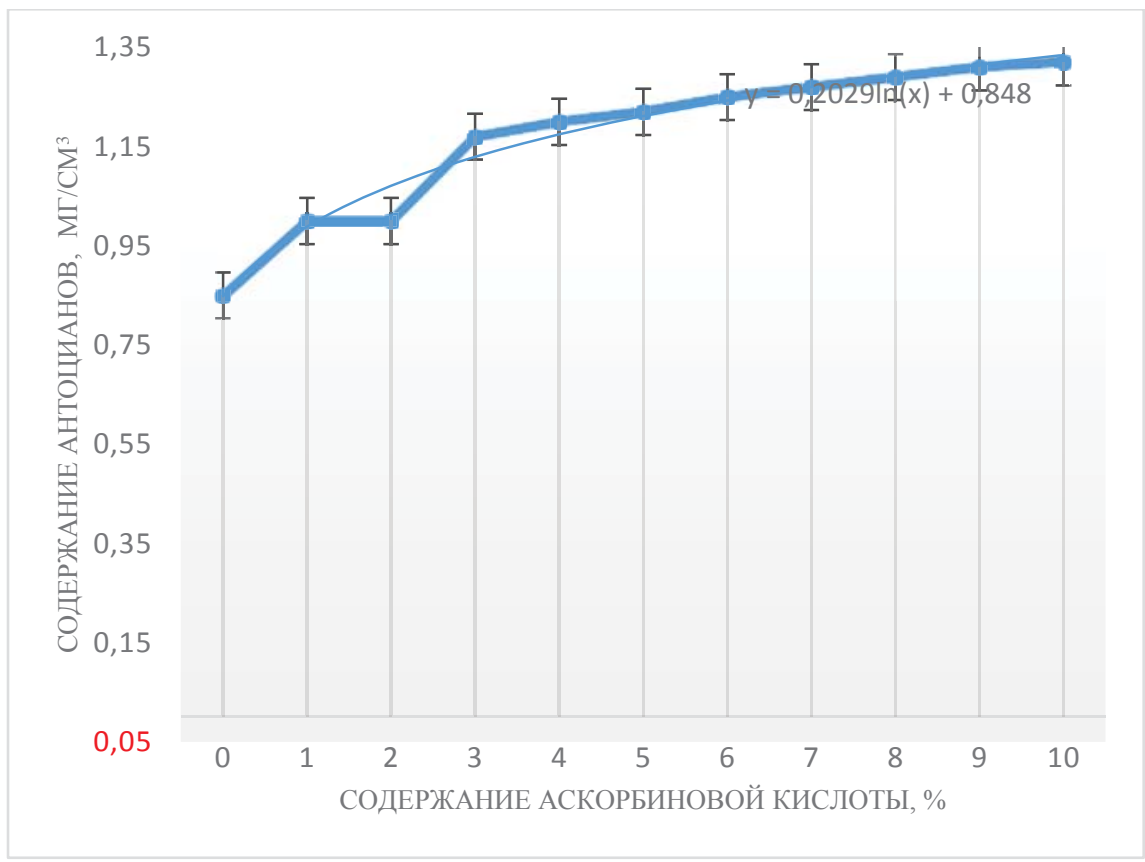

б)

Puc. 2.3. Зависимость выхода антоцианов от содержания аскорбиновой кислоты в растворе (условия проведения реакции: температура $-60{ }^{\circ} \mathrm{C}$, время - 30 мин): a) 0,2-1,0 \%-й раствор; б) 1,0-10,0 \%-й раствор

Антоцианы и аскорбиновая кислота являются нестабильными соединениями, поскольку, их биологическую активность определяют такие факторы как температура, время термического воздействия, а также способность к взаимодействию между собой $[42,74]$. Все это способствует снижению содержания и стабильности таких 
биологически активных соединений как цианидин-3-глюкозид и витамин С.

Влияние температуры и времени экстрагирования на степень выделения антоцианов в присутствии 1 и 10 \% растворов аскорбиновой кислоты представлено на рисунках 2.4 и 2.5 .

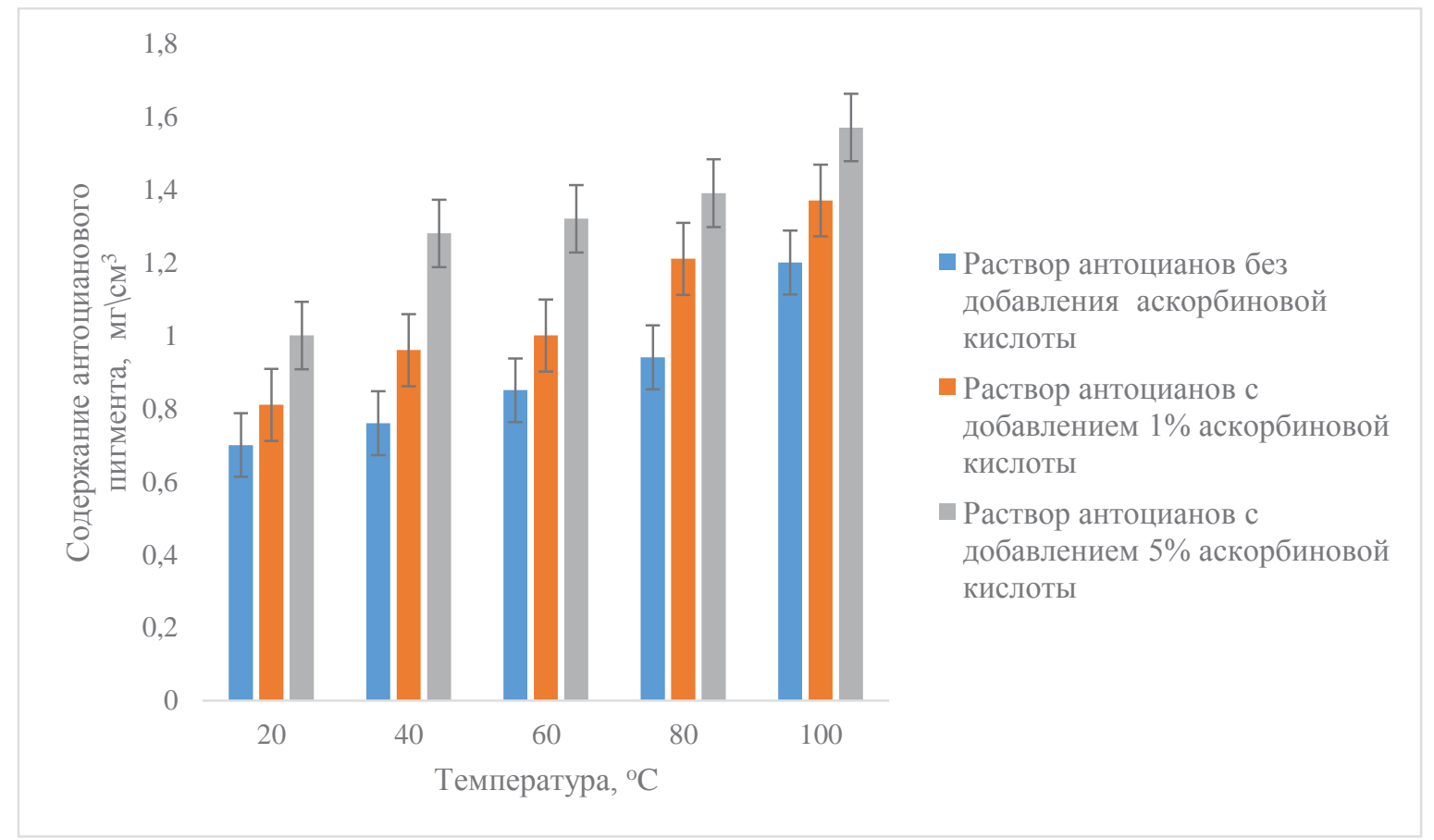

Puc. 2.4. Зависимость выхода антоцианов из ягодного сырья от температуры экстрагирования и содержания аскорбиновой кислоты в растворе (1,0 и 10,0 \%-е растворы)

Из представленных результатов (рисунок 2.4) видно, что температура оказывает существенное влияние на выход антоцианов в присутствии 1 и $10 \%$ растворов аскорбиновой кислоты. Наименьший выход антоцианов с добавлением 1 и $10 \%$ растворов аскорбиновой кислоты и без нее наблюдается при экстрагировании антоцианов в течение 30 мин при температуре $20{ }^{\circ} \mathrm{C}$. Дальнейшее повышение температуры экстрагирования приводит к увеличению выхода антоцианов в раствор. Наибольший выход антоцианов наблюдается при их экстрагировании при $100{ }^{\circ} \mathrm{C}$ в течение 2,5 мин. Степень извлечения антоцианов в присутствии 1 и $10 \%$ аскорбиновой кислоты повышается в 1,7 и 1,4 раз, соответственно. 


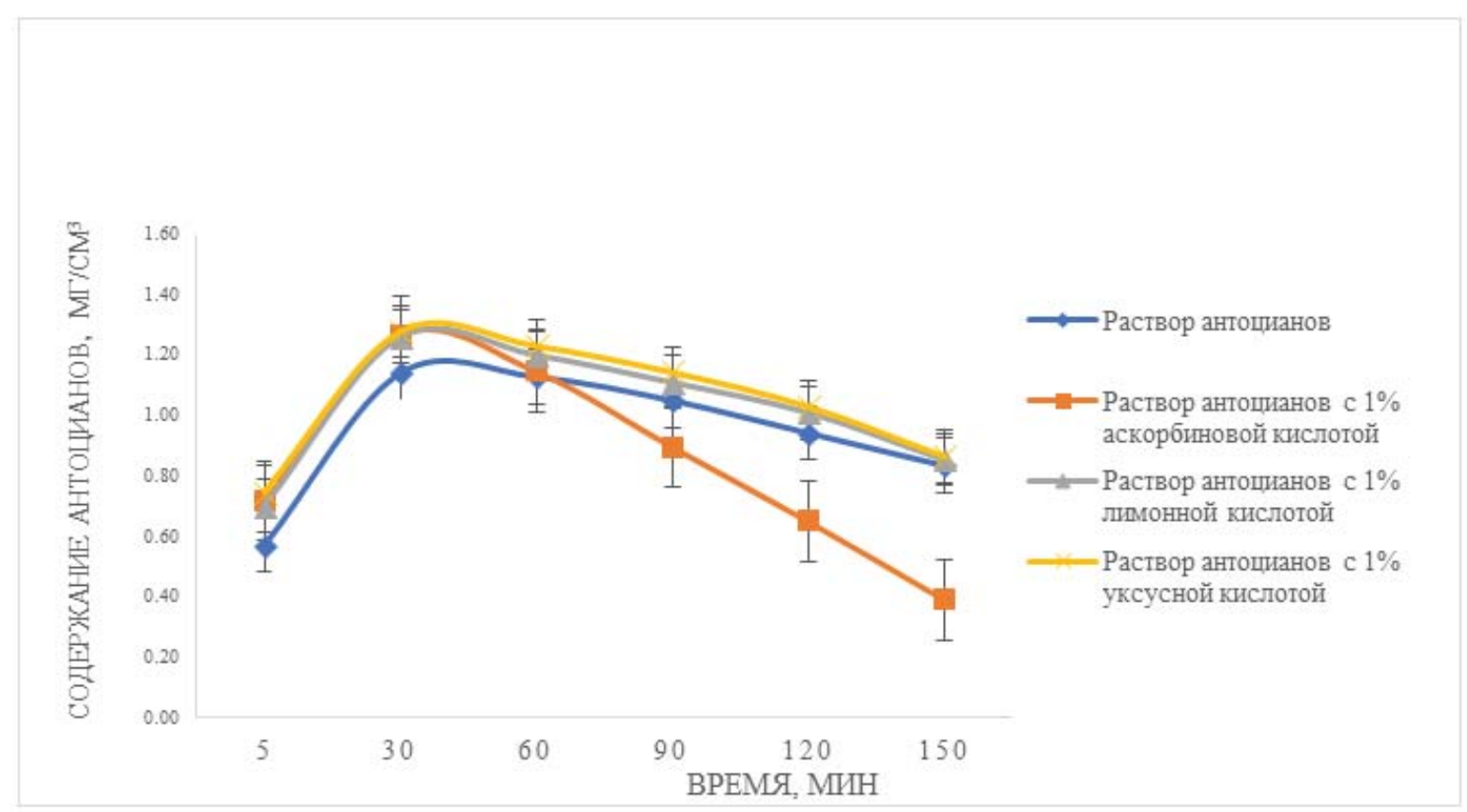

Puc. 2.5. Зависимость выхода антоцианов от времени экстрагирования и присутствия пищевых кислот в растворе

Из результатов, представленных на рисунке 2.5 видно, что продолжительность экстрагирования антоцианов по-разному влияет на их стойкость и определяется видом кислоты, используемой для извлечения. Наибольший выход антоцианов без добавок и в присутствии $1 \%$ аскорбиновой и 1 \%-х пищевых кислот, таких как лимонная и уксусная, наблюдается при продолжительности воздействия 30 мин при температуре $80{ }^{\circ} \mathrm{C}$. Дальнейшее увеличение времени экстрагирования приводит к падению выхода антоцианов раствор. При продолжительности воздействия 150 мин степень извлечения антоцианов в присутствии $1 \%$-х уксусной и лимонной кислот и без их добавления падает в 1,5, 1,5 и 1,4 ра3, соответственно. При этом изменение окраски растворов не наблюдается. Вероятно, подкисление раствора антоцианов пищевыми кислотами оказывает стабилизирующее действие на пигмент.

Наибольшее падение выхода антоцианов при времени экстрагирования 60-150 мин наблюдается в присутствии $1 \%$ аскорбиновой кислоты, вызывая деградацию антоцианов. Степень извлечения пигмента при времени экстрагирования 150 мин падает в 3,2 раза. При этом происходит изменение цветности экстракта, раствор пиг- 
мента приобретает бурую окраску. Вероятно, аскорбиновая кислота снижает стабильность антоцианов из-за реакции конденсации, либо разложение антоцианов вызвано продуктами окисления аскорбиновой кислоты [74].

Таким образом, добавление в раствор антоцианов аскорбиновой кислоты способствует извлечению антоцианов при температурах воздействия $20-80{ }^{\circ} \mathrm{C}$ в течение 30 мин и $100{ }^{\circ} \mathrm{C}$ в течение 2,5 мин. Увеличение времени воздействия до 60-150 мин приводит к падению степени извлечения антоцианов и изменению цветности их растворов.

\section{3. Использование полисахаридов \\ в качестве эффективных экстрагентов \\ для выделения антоцианов из ягодного сырья}

В данной главе показана возможность использования анионных полисахаридов в качестве эффективных экстрагентов для выделения антоцианов из ягодного сырья.

Для исследования использовали анионный полисахарид - каппакаррагинан, катионный - хитозан и нейтральный полисахарид крахмал. Зависимость значений оптической плотности растворов антоцианов от содержания и вида вводимого полисахарида представлена на рисунке 2.6.

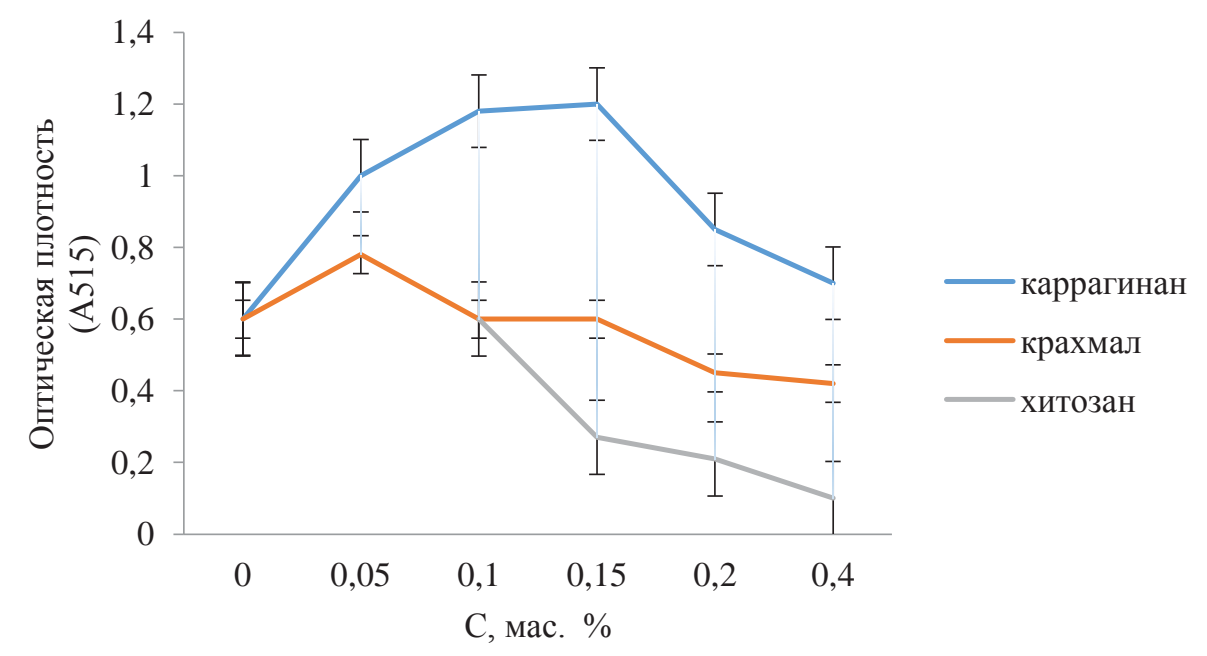

Puc. 2.6. Зависимость значений оптической плотности растворов антоцианов от содержания и вида вводимого полисахарида 
Из результатов, представленных на графике видно, что введение в систему анионного полисахарида каппа-каррагина в качестве экстрагента способствует извлечению антоцианов из ягодного сырья. Максимум содержания пигмента достигается при введении в систему каппа-каррагинана 0,15 мас. \%. Это объясняется электростатическим взаимодействием анионного полисахарида каппа-каррагинана и катионных антоцианов. Образуется стойкий комплекс за счет взаимодействия, содержащегося в гетероциклическом кольце антоцианов кислорода, способного взаимодействовать с отрицательно заряженными сульфатными группами полисахарида. Дальнейшее увеличение содержания каппа-каррагинана (0,2-0,4 мас. \%) в системе возможно ведет к насыщению гетероциклического кольца, что приводит к снижению значений оптической плотности растворов антоцианов.

Использование в качестве экстрагента катионного полисахарида хитозана не влияет на значения оптической плотности растворов. В растворах катионного полисахарида и катионных антоцианов наблюдается электростатическое отталкивание между одноименно заряженными функциональными группами [46]. Дальнейшее увеличение содержания хитозана в системе приводит к абсорбции его с пектинами и белками, находящимися в комплексе с антоцианами, что вызывает разрушение комплекса и потерю пигмента.

Нейтральный полисахарид крахмал при 0,05 мас. \% содержании в системе незначительно увеличивает значения оптической плотности растворов антоцианов. Дальнейшее увеличение содержания крахмала в системе пигмент-полисахарид ведет к незначительному снижению экстрагирования антоцианов.

Поскольку стабильность антоцианов существенно зависит от $\mathrm{pH}$ системы [72], причина столь сложной зависимости степени их выделения выявляется из рассмотрения результатов по изменению $\mathrm{pH}$ раствора антоцианов в присутствии полисахаридов, поскольку полисахариды, вероятно, могут оказывать влияние на изменение $\mathrm{pH}$ системы. Зависимость рН раствора антоцианов от содержания и вида вводимого в систему полисахарида приведена на рисунке 2.7. 


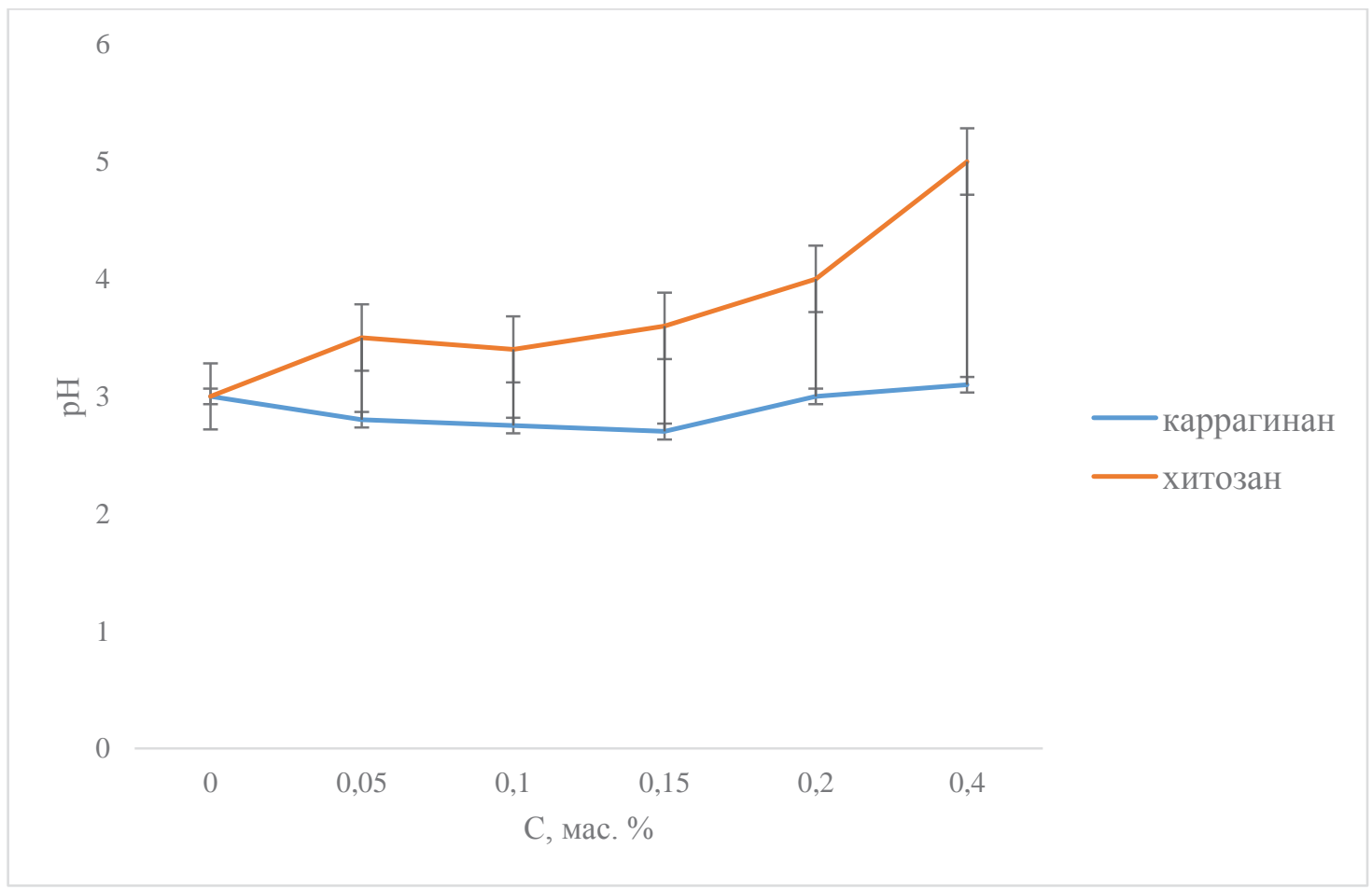

Рuс. 2.7. Зависимость $\mathrm{pH}$ раствора антоцианов от содержания и вида вводимого в систему полисахарида

Полученные данные показывают, что добавление анионного полисахарида каппа-каррагинана и катионного полисахарида хитозана в систему, содержащую антоцианы, ведет к изменению рН этой системы.

Сопоставление данных зависимости изменения оптической плотности системы пигмент-полисахарид (рисунок 2.6) с изменением pH раствора антоцианов в присутствие анионного полисахарида каппа-каррагинана показывает, что наибольшему извлечению антоцианов соответствует наименьшее значение $\mathrm{pH}$ раствора $(\mathrm{pH}=2,7)$ при содержании полисахарида 0,05 мас. \%.

Введение в систему катионного полисахарида хитозана повышает $\mathrm{pH}$ системы от 3 до 5, тем самым снижая их выделение. В кислой среде $(\mathrm{pH} \leq 2)$ антоцианы устойчивы к воздействию внешних факторов, так как они существуют в виде ярко красного катиона флавилиума, поэтому при данных значениях рН они стабильны [52]. При повышении рН от 2 до 6 происходит образование бесцветных псевдооснования (карбинол) и халкона, что приводит к распаду антоцианов и, соответственно, к падению интенсивности их окраски. Это указывает на то, что снижение выделения антоцианов из ягодного сырья при 
увеличении в системе анионного полисахарида обусловлено не только насыщением гетероциклического кольца антоцианов, но и зависит от $\mathrm{pH}$ раствора.

Так как вид полисахарида может в значительной степени влиять на экстрагирование антоцианов из ягодного сырья, в работе была изучена зависимость значений оптической плотности растворов антоцианов от вида вводимого полисахарида и природы его функциональных групп.

УФ-спектры растворов антоцианов с анионными полисахаридами представлены на рисунке 2.8. Содержание анионных полисахаридов в растворе составляло 0,05 мас. \%. В качестве контроля использовали раствор антоцианов без полисахаридов.

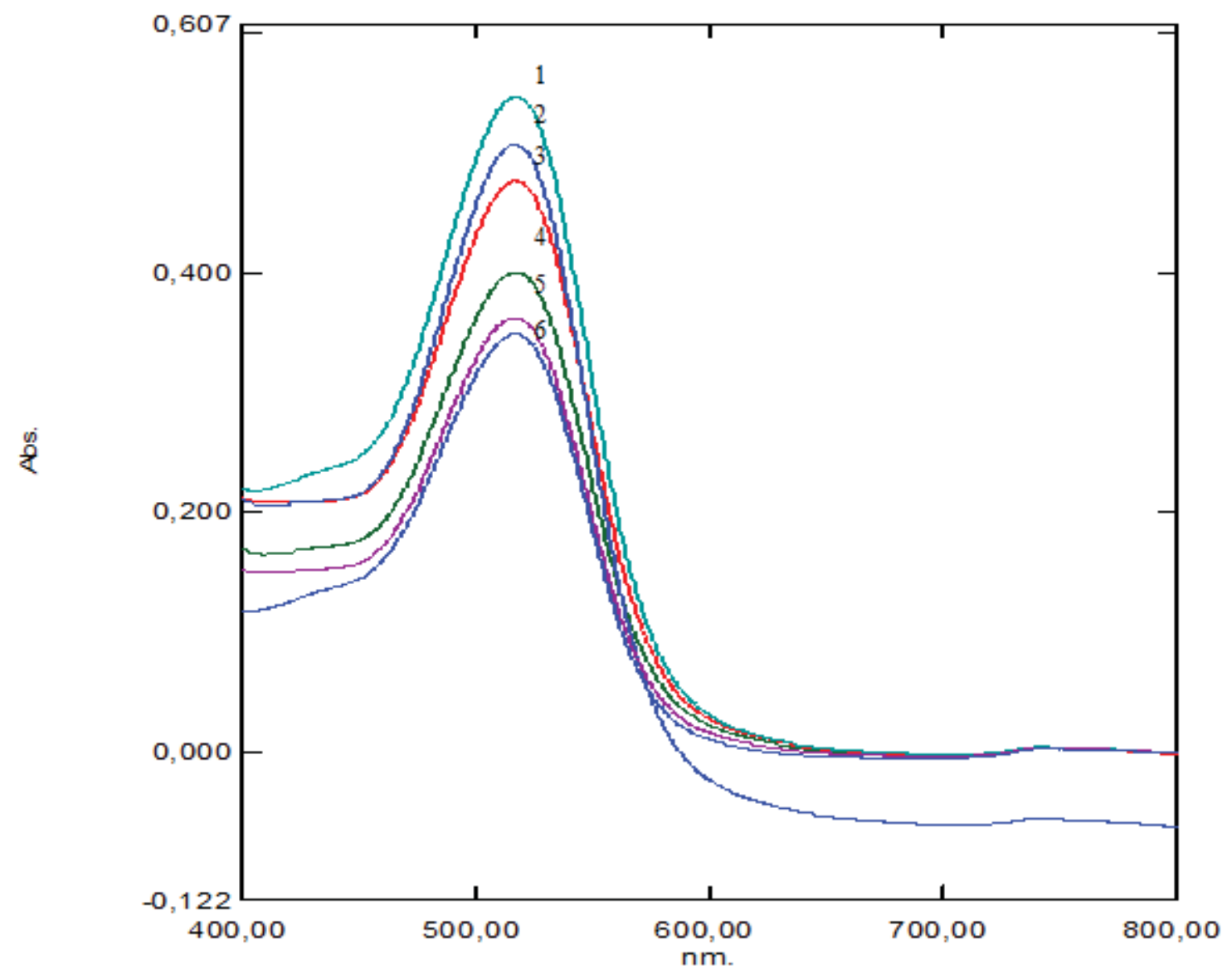

Puc. 2.8. УФ-спектры комплексов антоцианов

с анионными полисахаридами:

1. каппа-каррагинан, 2. агар-агар, 3. КМЦ,

4. альгинат натрия, 5. пектин, 6. антоцианы, выделенные без добавления полисахаридов 
Из представленных результатов видно, что все вводимые в систему анионные полисахариды увеличивают степень извлечения антоцианов из ягодного сырья. Вероятно, между анионными полисахаридами и катионными антоцианами образуются стойкие оксониевые комплексы за счет содержащегося в гетероциклическом кольце антоцианов кислорода, способного электростатически взаимодействовать с отрицательно заряженными функциональными группами полисахаридов.

Из полученных результатов видно, что существенным фактором, определяющим степень извлечения антоцианов, является природа функциональных групп полисахаридов. Более полному извлечению антоцианов способствуют присутствующие в структуре каппакарагинана и агар-агара сульфатные группы. Увеличение степени извлечения антоцианов в присутствии каппа-каррагинана и агар-агара составляет 2,0 и 1,6, соответственно. Поскольку сульфатные группы в молекуле каппа-каррагинана и агар-агара являются более реакционноспособными [36], это возможно приводит к образованию стойких комплексов между антоцианами и полисахаридами и, соответственно, более полному их извлечению.

Добавление в систему КМЦ, альгината натрия и пектиновых веществ, увеличивает степень извлечения антоцианов в 1,5, 1,3, 1,1 раз, соответственно. Вероятно, присутствующие в молекуле КМЦ карбоксиметильные группы способствуют выделению антоцианов в большей степени, чем присутствующая в молекуле альгината натрия альгиновая кислота. Наименьшими экстрагирующими свойствами обладают пектиновые вещества. Присутствующие в молекуле пектиновых веществ карбоксильные группы, придают им слабые кислотные свойства.

УФ-спектры поглощения растворов антоцианов с различным содержанием в них анионных полисахаридов представлены на рисунке 2.9.

Из представленных результатов видно, что различное содержание анионных полисахаридов в системе по-разному влияет на экстрагирование антоцианов. 


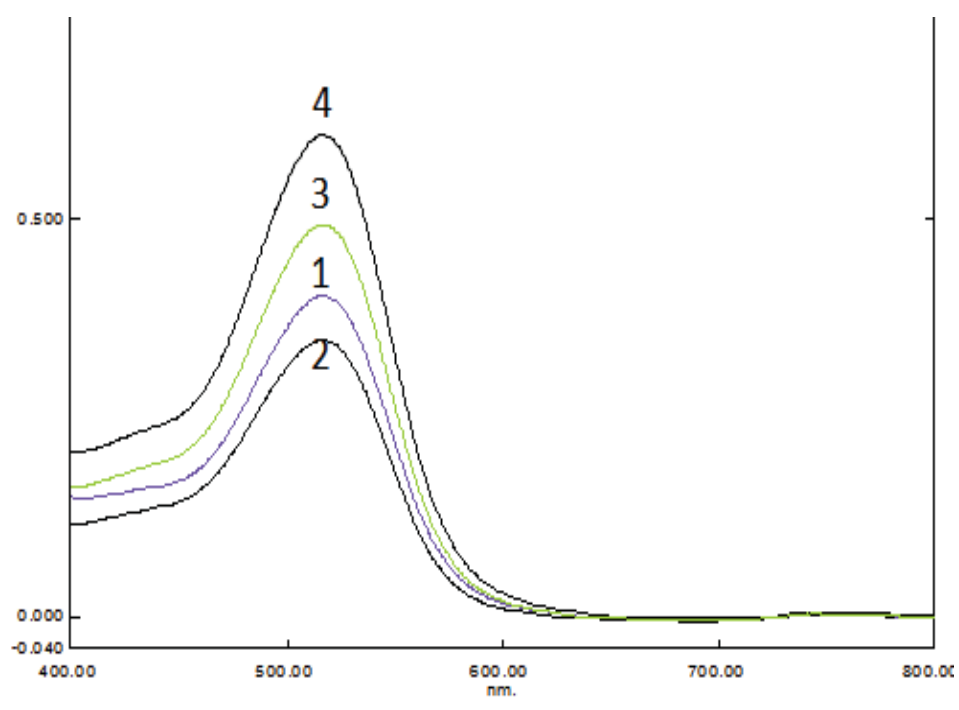

a)

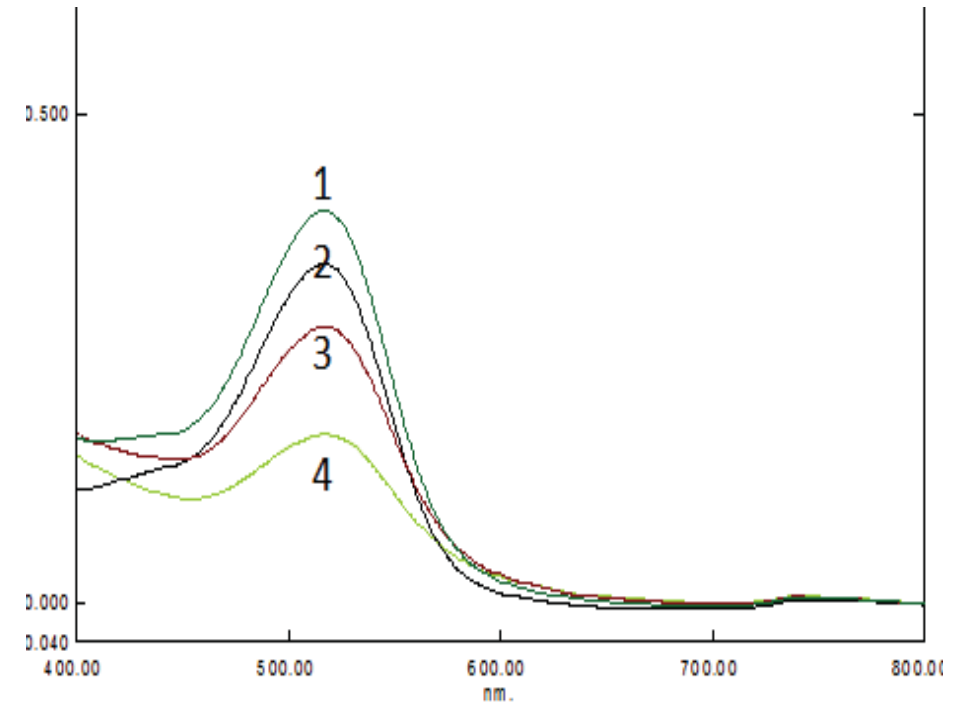

б)

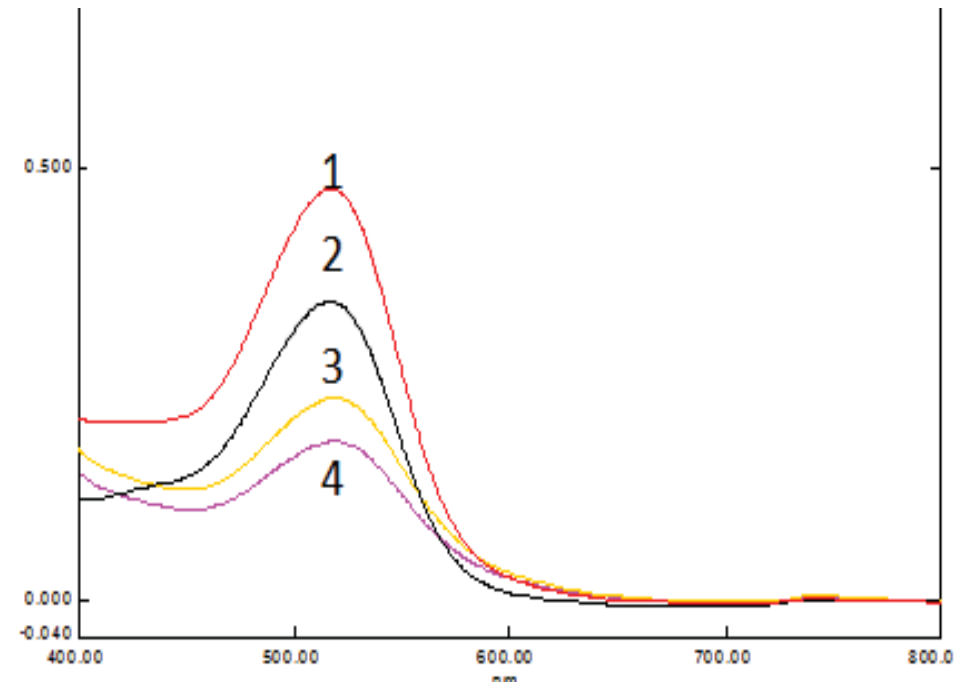

в) 

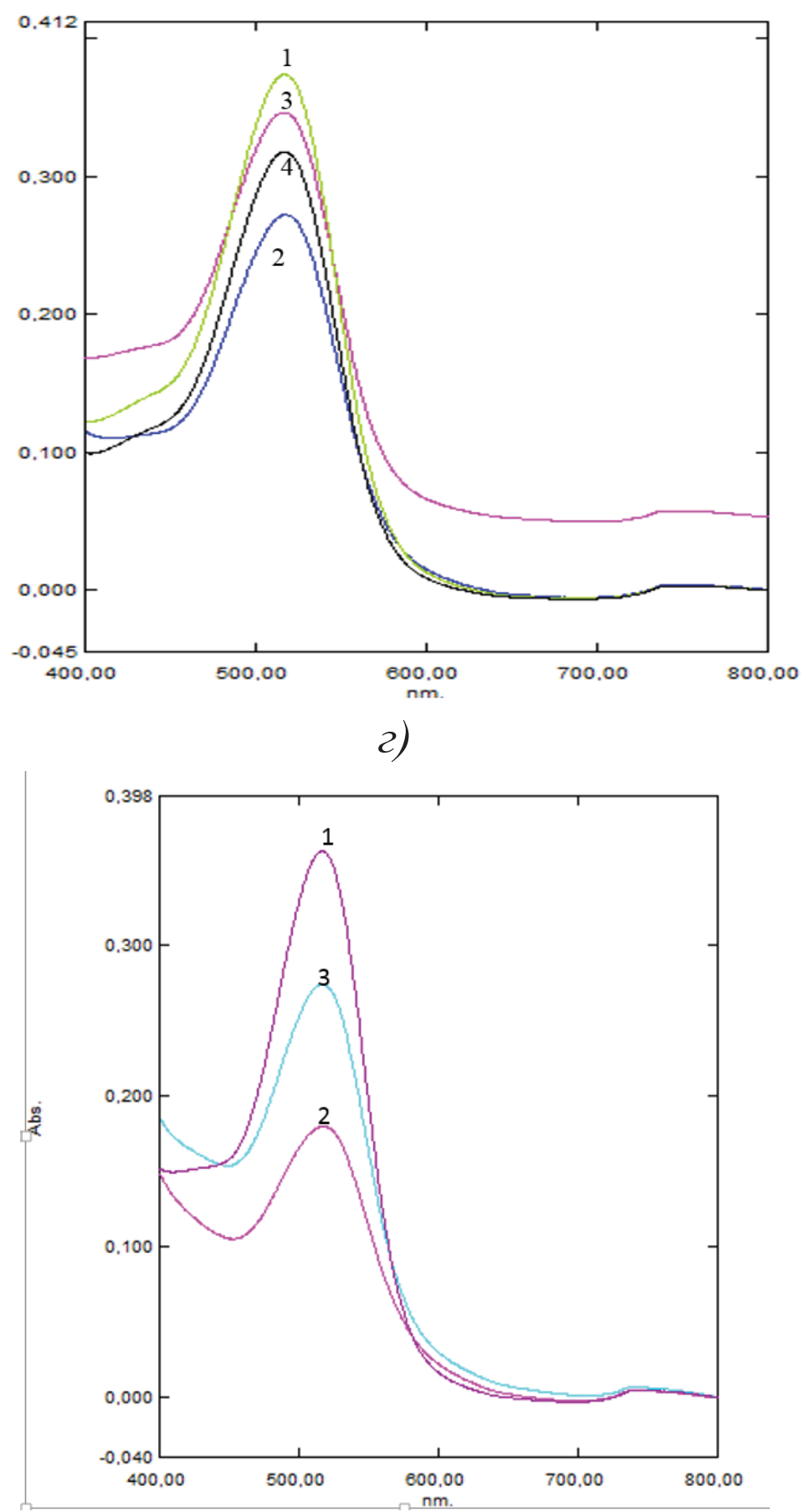

d)

Puc. 2.9. УФ-спектры поглощения растворов антоцианов с различным содержанием в них анионных полисахаридов:

(a) каппа-каррагинан, б) альгинат натрия, в) КМЦ, 2) агар-агар и $\partial)$ пектин (1 - 0.05 мас. \%; 2 - антоцианы, выделенные без полисахаридов; 3 - 0,1 мас. \%; 4-0,15 мас. \%)

Повышение содержания каппа-каррагинана в растворе до 0,1 и 0,15 мас. \% способствует извлечению антоцианов из ягодного сы- 
рья. Степень извлечения увеличивается в 1,6 и 2,3 раза, соответственно. Максимальное извлечение пигмента также наблюдается в присутствии 0,05 мас. \% альгината натрия, КМЦ, агар-агара и пектина.

Напротив, повышение содержания альгината натрия, КМЦ, агарагара и пектина в растворе до 0,15 мас. \% способствует снижению извлечения антоцианов. Степень извлечения антоцианов при использовании в качестве экстрагентов альгината натрия, КМЦ, агар-агара и пектина в 1,4, 1,8, 1,6 и 1,4 раз, соответственно. Видимо, наиболее оптимальным содержанием альгината натрия, КМЦ, агар-агара и пектина в системе для выделения антоцианов является 0,05 мас.\%. Дальнейшее их увеличение приводит к насыщению положительно заряженного кислорода, расположенного в гетероциклическом кольце молекулы антоцианов и как, следствие, снижению интенсивности их экстрагирования.

Таким образом, при извлечении антоцианов наиболее эффективным является их экстрагирование в присутствии анионных полисахаридов. Существенным фактором, определяющим степень извлечения антоцианов, является природа функциональных групп полисахаридов. Наиболее полно антоцианы экстрагируется при использовании таких анионных полисахаридов как каппа-каррагинан, агар-агар, КМЦ, альгинат натрия и пектин.

\section{4. Использование белков \\ в качестве эффективных экстрагентов для выделения антоцианов из ягодного сырья}

Использование в качестве экстрагентов полимеров белковой природы - желатина, яичного альбумина и бычьего сывороточного альбумина (БСА) также эффективно для выделения антоцианов из ягодного сырья. 


\subsection{1. Использование желатина}

\section{для экстрагирования антоцианов из ягодного сырья}

УФ-спектры растворов, содержащих антоцианы жимолости и черной смородины, а также 0,2 и 0,6 \% желатина представлены на рисунках 2.10 и 2.11. В качестве контроля использовали растворы антоцианов жимолости и черной смородины без желатина.

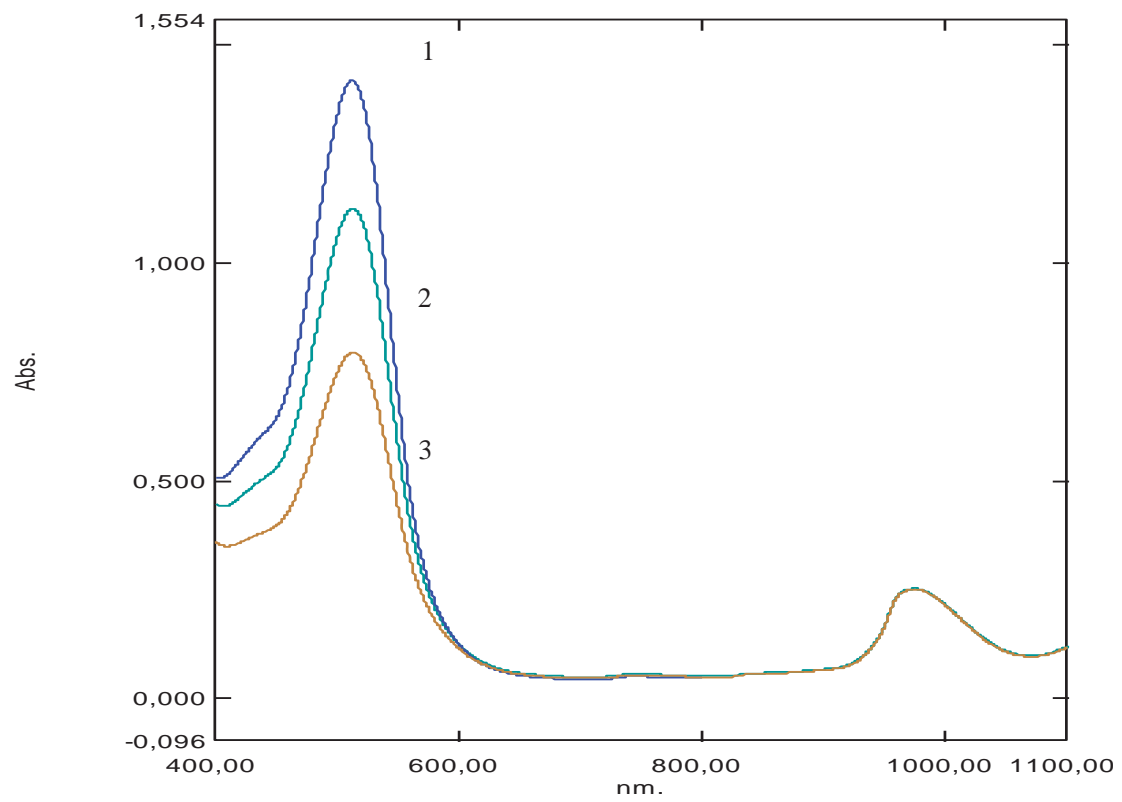

Puc. 2.10. УФ-спектры растворов антоцианов жимолости и желатина:

1. без желатина; 2. 0,2 \% желатина;

3. $0,6 \%$ желатина

Результаты, представленные на рисунках показваеют, что введение в систему желатина по-разному влияет на выделение антоцианов из ягод жимолости и черной смородины. Введение в систему 0,2 \% желатина (рисунок 2.10) снижает значение оптической плотности антоцианов жимолости с 1,45 до 1,15 . При увеличении содержания в системе желатина с 0,2 до 0,6 \% значение оптической плотности антоцианов снижается с 1,15 до 0,75. Степень извлечения антоцианового пигмента жимолости снижается в 1,3 и 1,5 раз в зависимости от присутствия в растворе 0,2 и $0,6 \%$ желатина.

Напротив, введение в систему 0,2 \% желатина увеличивает значение оптической плотности антоцианов черной смородины (рисунок 
2.11). Повышение содержания желатина в системе до 0,6 \% способствует выделению антоцианов и повышению степени их извлечения в 1,2 раз.

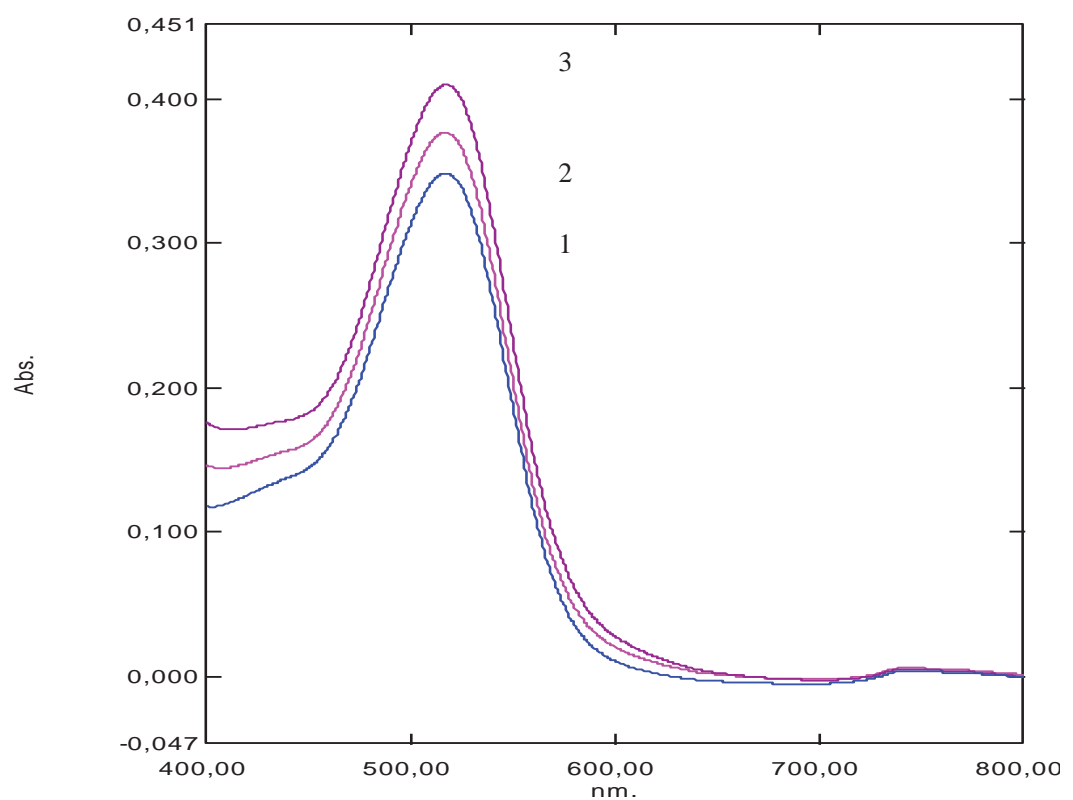

Pис. 2.11. УФ-спектры растворов антоцианов черной смородины и желатина:

1. без желатина; 2. 0,2 \% желатина;

3. $0,6 \%$ желатина

Разное влияние желатина на степень извлечения антоцианов, видимо, зависит от нескольких факторов. Устойчивость антоцианов существенно зависит от $\mathrm{pH}$ системы. Значения $\mathrm{pH}$ растворов антоцианов черной смородины и жимолости составляют 3,0 и 3,4, соответственно. Анализ зависимости значений оптической плотности системы пигмент-желатин (рисунки 2.10 и 2.11) от величины $\mathrm{pH}$ растворов антоцианов жимолости и черной смородины показывает, что максимальной степени выделения антоцианов черной смородины соответствует значение $\mathrm{pH} \mathrm{3,} \mathrm{тогда} \mathrm{как} \mathrm{увеличение} \mathrm{pH}$ антоцианов жимолости $(\mathrm{pH}=3,4)$ приводит к уменьшению степени их извлечения. Важной характеристикой желатина является присутствие в его молекуле пролина и основных аминокислот, содержащих реакционноспособные аминогруппы, благодаря которым могут возникать водородные связи с отрицательно заряженными группами молекулы антоцианов. Смещение от изоэлектрической точки (ИЭТ) желатина (ИЭТ - 4,7) в кис- 
лую область ( $\mathrm{pH}=3)$, по-видимому, вызывает более полное связывание положительно заряженных групп в молекуле белка с ОНгруппами антоцианов.

Другим фактором, оказывающим существенное влияние на степень извлечения антоцианов, может служить различный состав антоцианидинов и количество входящих в их молекулу ОН-групп. В литературных источниках отмечено [67], что более полное связывание антоцианов с белками происходит в случае присутствия в их составе большого количества ОН-групп, способных образовывать стойкие комплексы с молекулами белков.

Согласно литературным источникам, одной из причин различной зависимости степени выделения антоцианов жимолости и черной смородины от присутствия в реакционной среде желатина, может являться аскорбиновая кислота. Показано, что содержащаяся в растворе антоцианов аскорбиновая кислота способствует образованию стабильных комплексов антоциановый пигмент-белок [30].

Наиболее богатым источником витамина С служат ягоды черной смородины. Его содержание составляет 94,6-167,3 мг/100 г в зависимости от сорта [13]. Наибольший показатель антирадикальной активности у антоцианов, выделенных из черной смородины (таблица 1.2). У жимолости значение антирадикальной активности снижается. Кроме того, в отличие от других объектов исследования, в черной смородине наблюдается низкое содержание ферментов, разрушающих аскорбиновую кислоту, что придает ей высокие антирадикальные свойства [1].

Таким образом, присутствие желатина в реакционной среде существенно влияет на степень выделения антоцианов жимолости и черной смородины, вызывая как ее понижение, так и повышение. Причинами столь сложной зависимости является качественный состав молекулы антоцианов, величины рН системы и присутствующая в водном растворе антоцианов аскорбиновая кислота. 


\subsection{2. Использование яичного альбумина и БСА}

\section{для экстрагирования антоцианов}

\section{из ягодного сырья}

УФ-спектры растворов антоцианов жимолости, черной смородины и глобулярных белков - яичного альбумина и бычьего сывороточного альбумина (БСА) представлены на рисунках 2.12 и 2.13.

Из результатов, представленных на рисунках видно, что значения оптической плотности растворов антоцианов зависят от присутствия в реакционной среде исследуемых полимеров белковой природы - яичного альбумина и БСА.

Максимальные значения оптической плотности растворов антоцианов жимолости и черной смородины наблюдаются при введении в испытуемый раствор 0,1 \% яичного альбумина. Степень извлечения пигмента увеличивается в 1,5 и 0,8 раз, соответственно. Таким образом, повышение содержания яичного альбумина в растворе, приводит к снижению значений оптической плотности растворов.

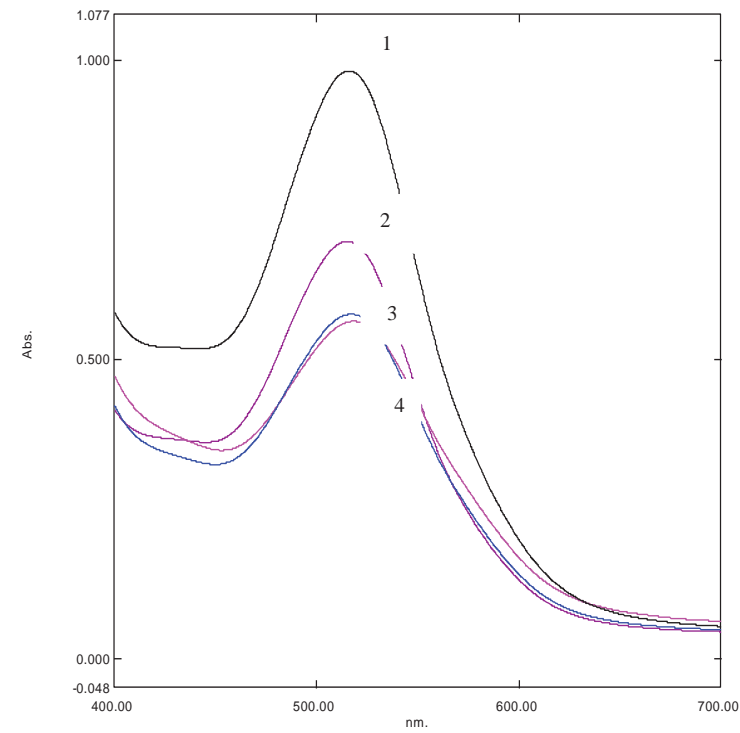

a)

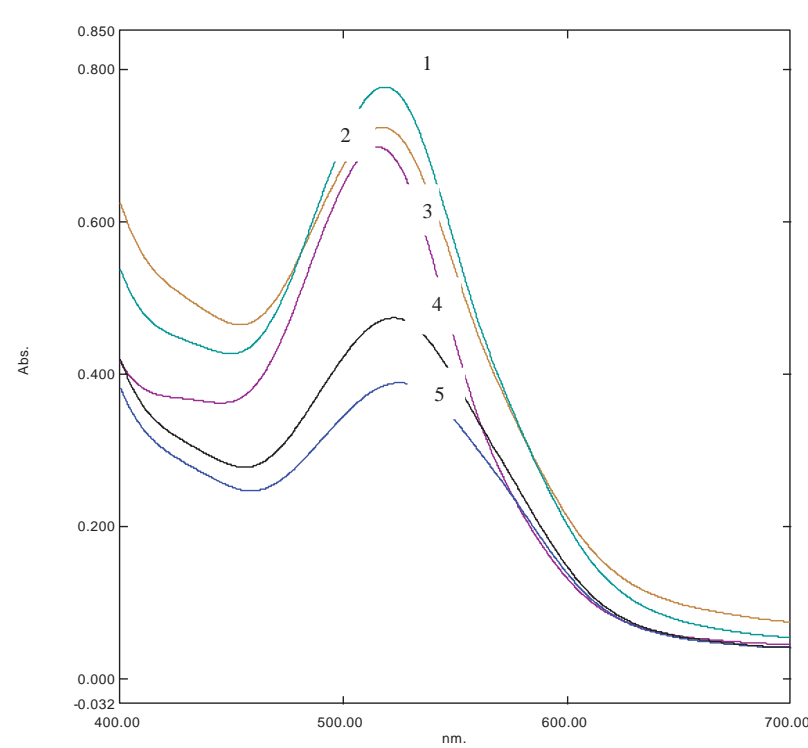

б)

Pис. 2.12. УФ-спектры растворов антоцианов жимолости и глобулярных белков: а) яичного альбумина (1. 0,1\%, 2. Антоцианы без добавления белка, 3. 0,5 \%, 4. 2,0 \%) и б) БСА (1. 0,1 \%, 2. 0,5 \%, 3. антоцианы без добавления белка 4. 2,0\%, 5. 4,0\%) 
Введение в систему 2,0 \% яичного альбумина снижает степень извлечения антоцианов жимолости и черной смородины в 1,2 и 1,6 раз, соответственно. Увеличение количества яичного альбумина в системе до 4,0 \% приводит к помутнению раствора антоцианов, что говорит о коагуляционных изменениях в молекуле белка.

Максимум извлечения антоцианов жимолости и черной смородины в присутствии БСА также наблюдается при $0,1 \%$ содержании белка в растворе. Степень извлечения антоцианов в присутствии $0,1 \%$ БСА увеличивается в 1,2 и 1,6 раз, соответственно. При дальнейшем добавлении БСА наблюдается, как и в присутствии яичного альбумина, снижение степени извлечения антоцианов. Степень извлечения антоцианов при содержании в растворе $4,0 \%$ БСА уменьшается в 1,8 и 5 раз, соответственно.

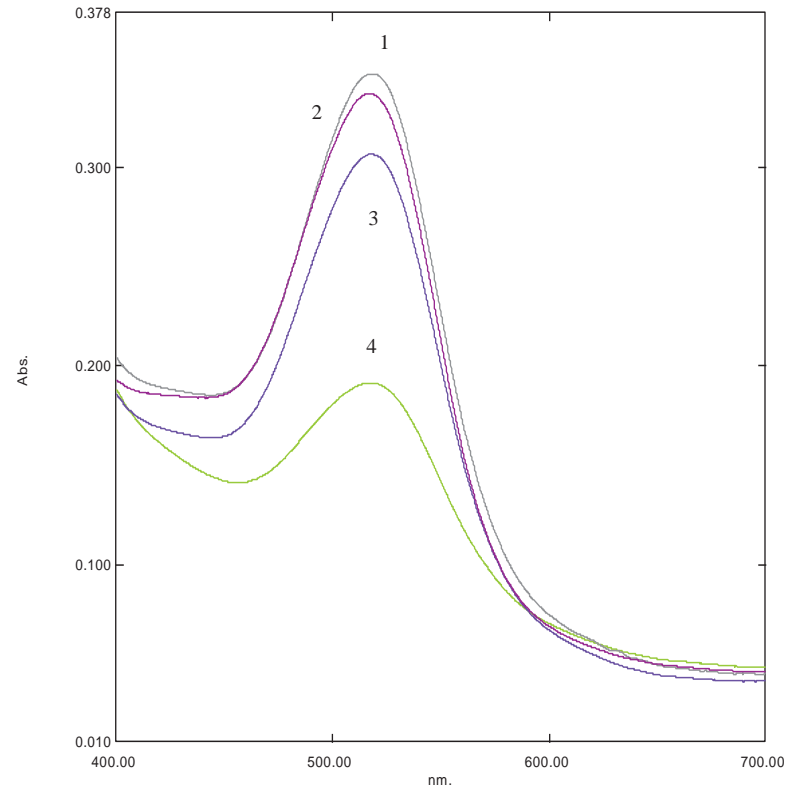

a)

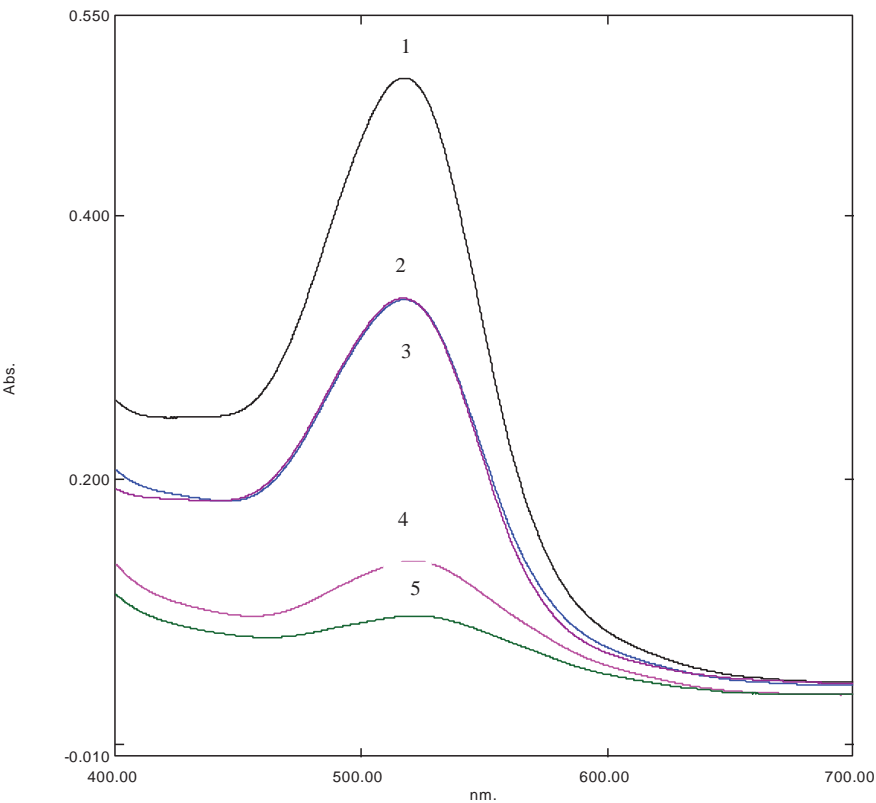

б)

Puc. 2.13. УФ-спектры растворов антоцианов черной смородины и глобулярных белков: а) яичного альбумина $(1.0,1 \%, 2$. антоцианы без добавления белка, 3. $0,5 \%, 4.2,0 \%)$ и б) БСА $(1.0,1 \%, 2.0,5 \%$, 3. антоцианы без добавления белка 4. 2,0 \%, 5. 4,0 \%)

Разное влияние белков на степень извлечения антоцианов зависит от $\mathrm{pH}$ системы. Значения $\mathrm{pH}$ растворов антоцианов жимолости и 
черной смородины в присутствии яичного альбумина и БСА представлены на рисунках 2.14 и 2.15.

Анализ УФ-спектров систем пигмент-белок (рисунки 2.12 и 2.13) от величины $\mathrm{pH}$ растворов антоцианов жимолости и черной смородины (рисунки 2.14 и 2.15) в присутствии яичного альбумина и БСА показывает, что максимальной степени извлечения соответствует наиболее кислая среда. Значения $\mathrm{pH}$ системы антоцианов жимолости и черной смородины в присутствии $0,1 \%$ раствора яичного альбумина составляет 3,64 и 3,44, соответственно. Значения $\mathrm{pH}$ системы антоцианов жимолости и черной смородины в присутствии 0,1 \% БСА составляет 3,90 и 3,46, соответственно. Увеличение содержания в системе белка приводит к повышению рН системы, в данном случае независимо от вида исследуемого белка. Так при введении в раствор антоцианов жимолости и черной смородины 2,0 \% яичного альбумина, значения рН системы увеличиваются и достигают 4,10 и 3,74, соответственно. Аналогичное повышение $\mathrm{pH}$ раствора наблюдается при использовании для выделения антоцианов 0,5 \%, 2,0 \% и 4,0 \% БСА. Значения $\mathrm{pH}$ антоцианов жимолости и черной смородины в присутствии 4,0 \% БСА составляет 4,55 и 4,30, соответственно.

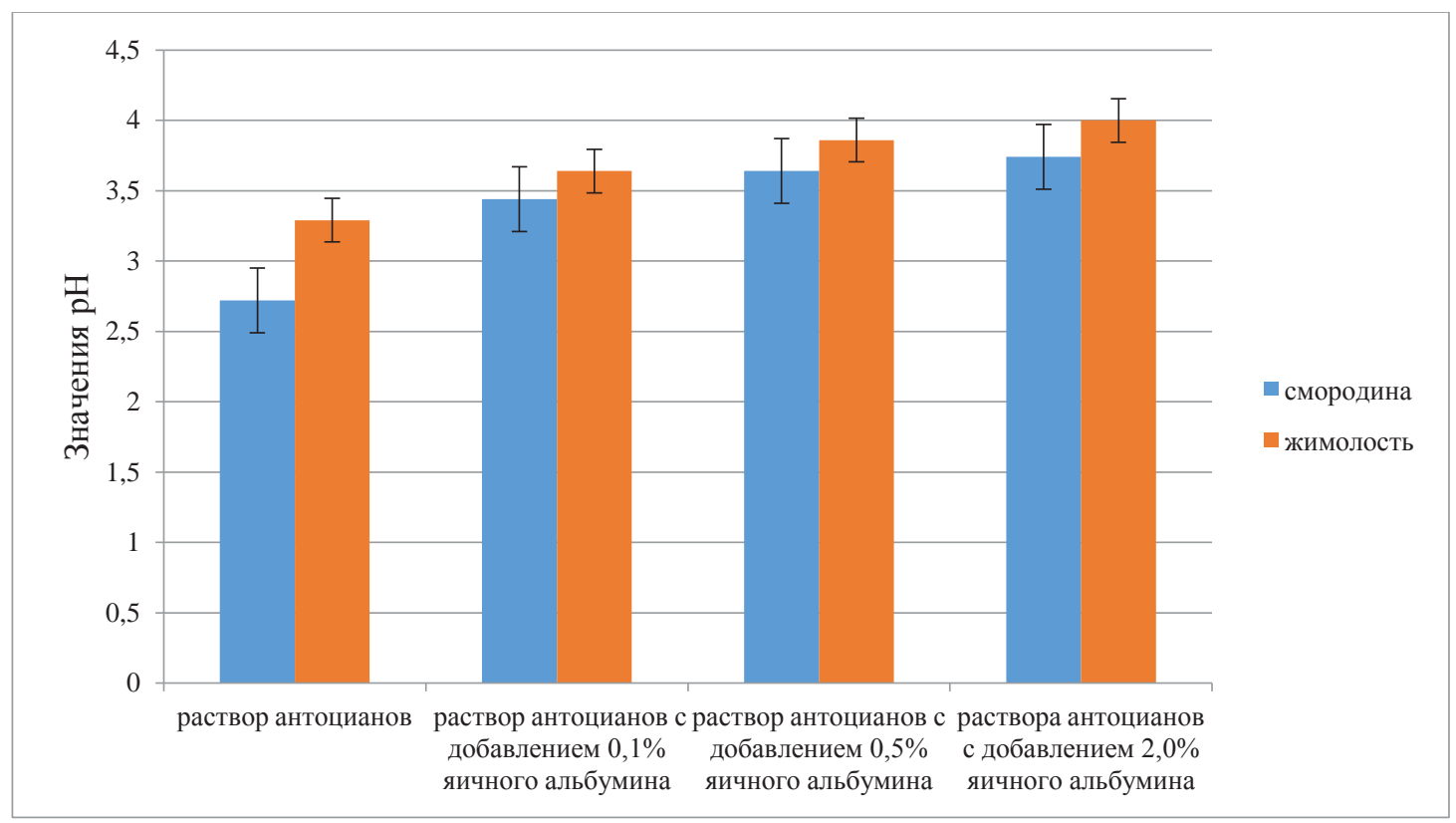

Puc. 2.14. pН растворов антоцианов с добавлением яичного альбумина 


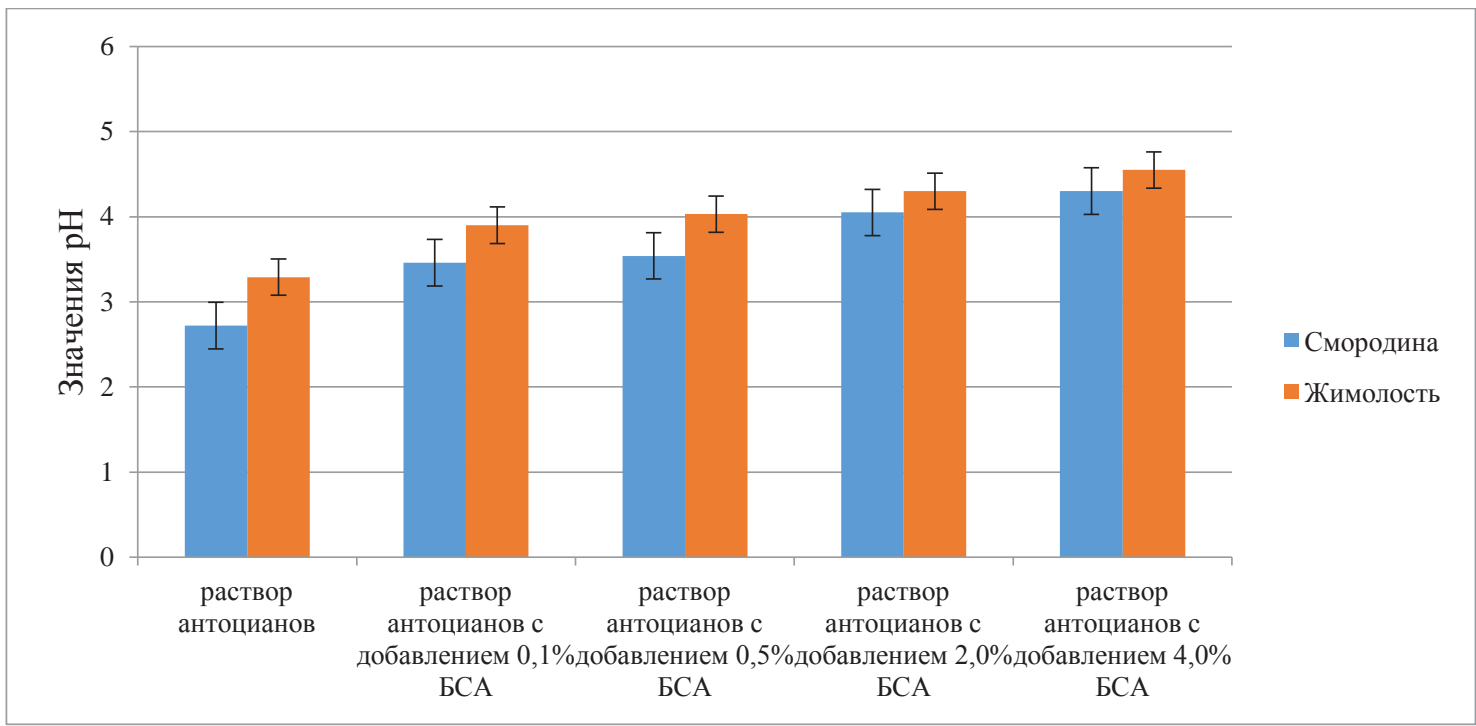

Puc. 2.15. $\mathrm{pH}$ раствора антоцианов с добавлением БСА

В кислой среде, по-видимому, наблюдается более полное связывание положительно заряженных групп в молекуле белка с ОНгруппами антоцианов. Повышение содержания белков в системе антоцианов увеличивает значения $\mathrm{pH}$ системы и приближает ее к значениям ИЭТ белков (ИЭТ альбумина - 4,8, БСА - 4,9), где наблюдается наименьшее взаимодействие яичного альбумина и БСА с молекулами антоцианов за счет снижения степени ионизации белков.

Таким образом, введение в раствор антоцианов глобулярных белков влияет на степень их извлечения из ягодного сырья. Наиболее интенсивно антоцианы выделяется в присутствии 0,1 \% яичного альбумина и БСА.

\section{5. Оптимизация технологий выделения антоцианов из ягодного сырья Дальневосточного региона}

Особое место среди современных методов экстрагирования, позволяющих ускорять массообменные процессы в растительных тканях, а также увеличивать выход биологически активных веществ занимает ультразвуковая экстракция.

С целью оптимизации процесса экстрагирования было изучено влияние ультразвука и условий выделения на выход антоцианов из ягодного сырья. Зависимость выхода антоцианов от метода выделения и температуры экстрагирования представлена на рисунке 2.16. 


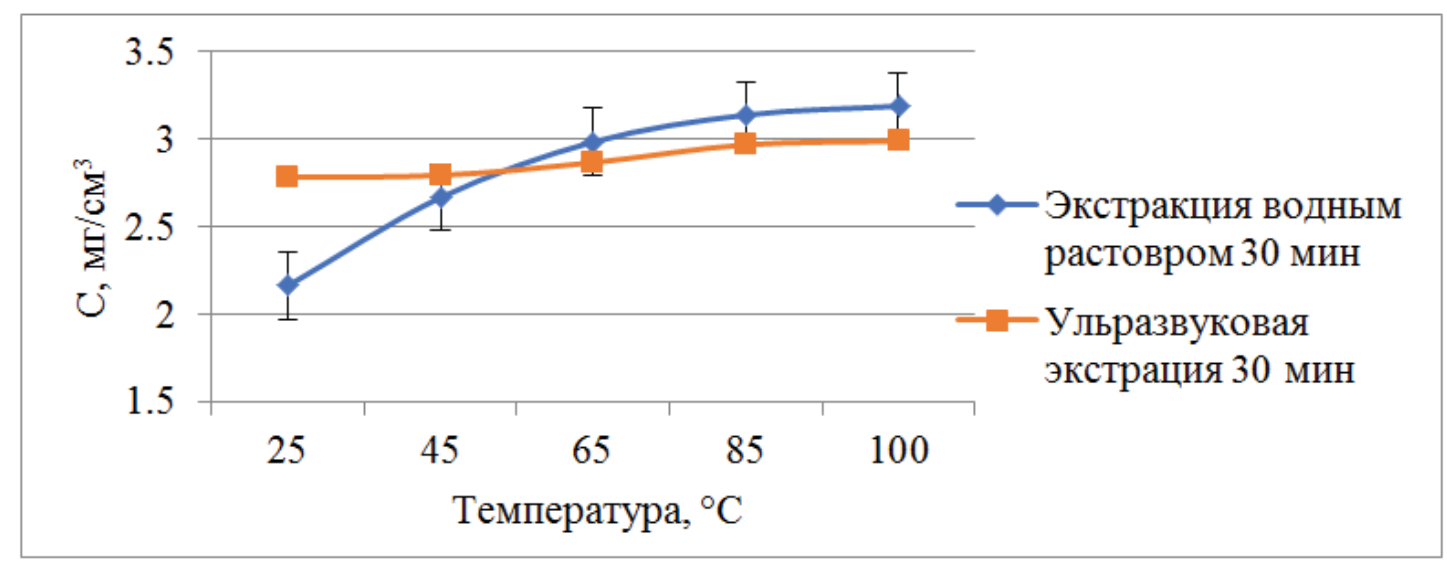

Puс. 2.16. Зависимость выхода антоцианов от метода выделения и температуры экстрагирования

Результаты, представленные на рисунке 2.16 показывают, что метод экстрагирования и температура влияют на выход антоцианов. Использование ультразвука для экстрагирования антоцианов из ягодного сырья при комнатной температуре увеличивает их выделение. При температуре $25^{\circ} \mathrm{C}$ содержание антоцианов в экстракте увеличивается на $22 \%$ по сравнению с экстракцией водным раствором при аналогичных условиях. Вероятно, это объясняется тем, что под действием ультразвуковых волн и кавитационного эффекта, который они производят, происходит интенсификация массопередачи и более легкий доступ растворителя к растительной клетке. При этом, распад кавитационных пузырей около стенок клеток приводит к разрушению клеточной стенки, способствуя более интенсивному проникновению внутрь клетки растворителя [7].

Повышение температуры экстрагирования до $65-70{ }^{\circ} \mathrm{C}$ способствует увеличению выхода антоцианов, как при ультразвуковой экстракции, так и при экстрагировании водным раствором. При данной температуре количество выделившегося пигмента, экстрагированного водным раствором выше, чем при ультразвуковой экстракции и со-

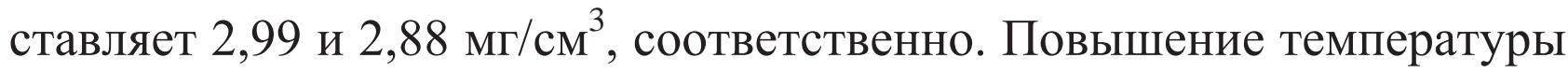
до $100{ }^{\circ} \mathrm{C}$ незначительно увеличивает выход антоцианов. При данных условиях выход пигмента, экстрагированного водным раствором и

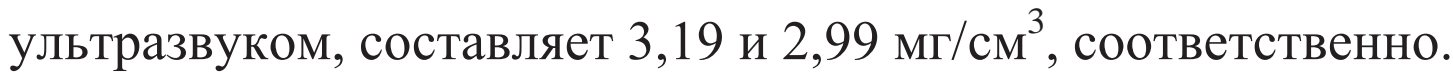


С целью определения оптимальных условий экстрагирования была изучена зависимость выхода антоцианов от времени экстрагирования, поскольку продолжительность экстракции может существенно влиять на выход антоцианов. Зависимости выхода антоцианов от метода, продолжительности и температуры экстрагирования представлены на рисунке 2.17 и 2.18 .

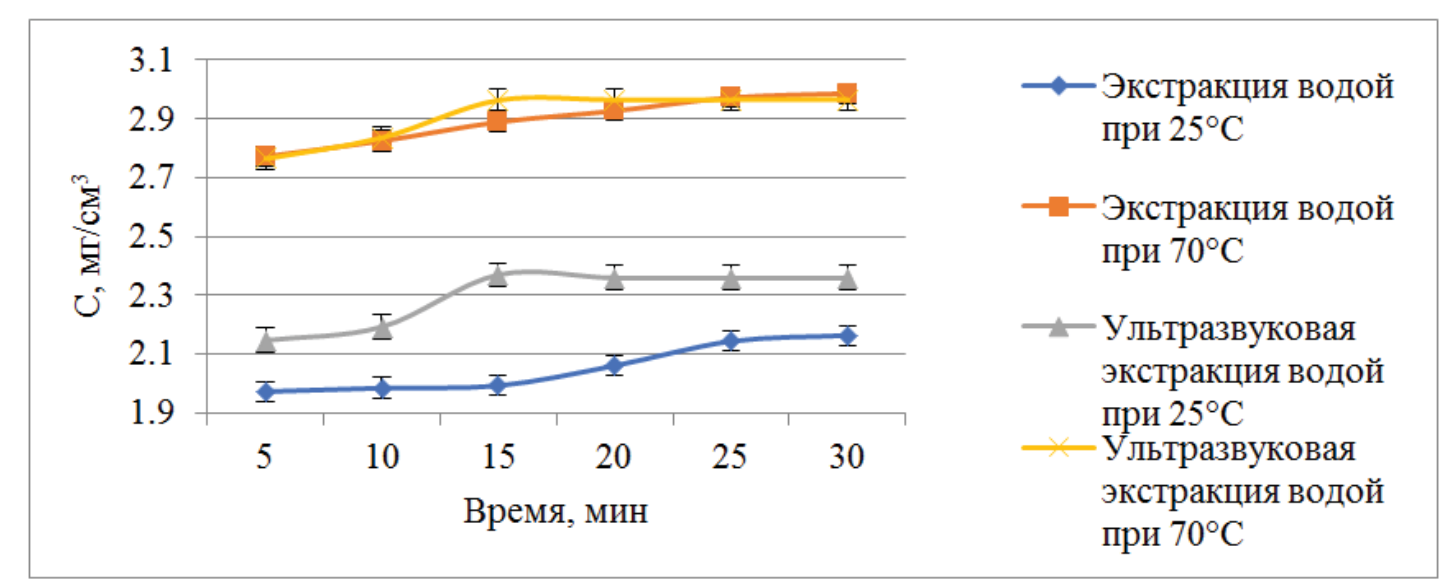

Рис. 2.17. Зависимость выхода антоцианов от метода, продолжительности и температуры экстрагирования

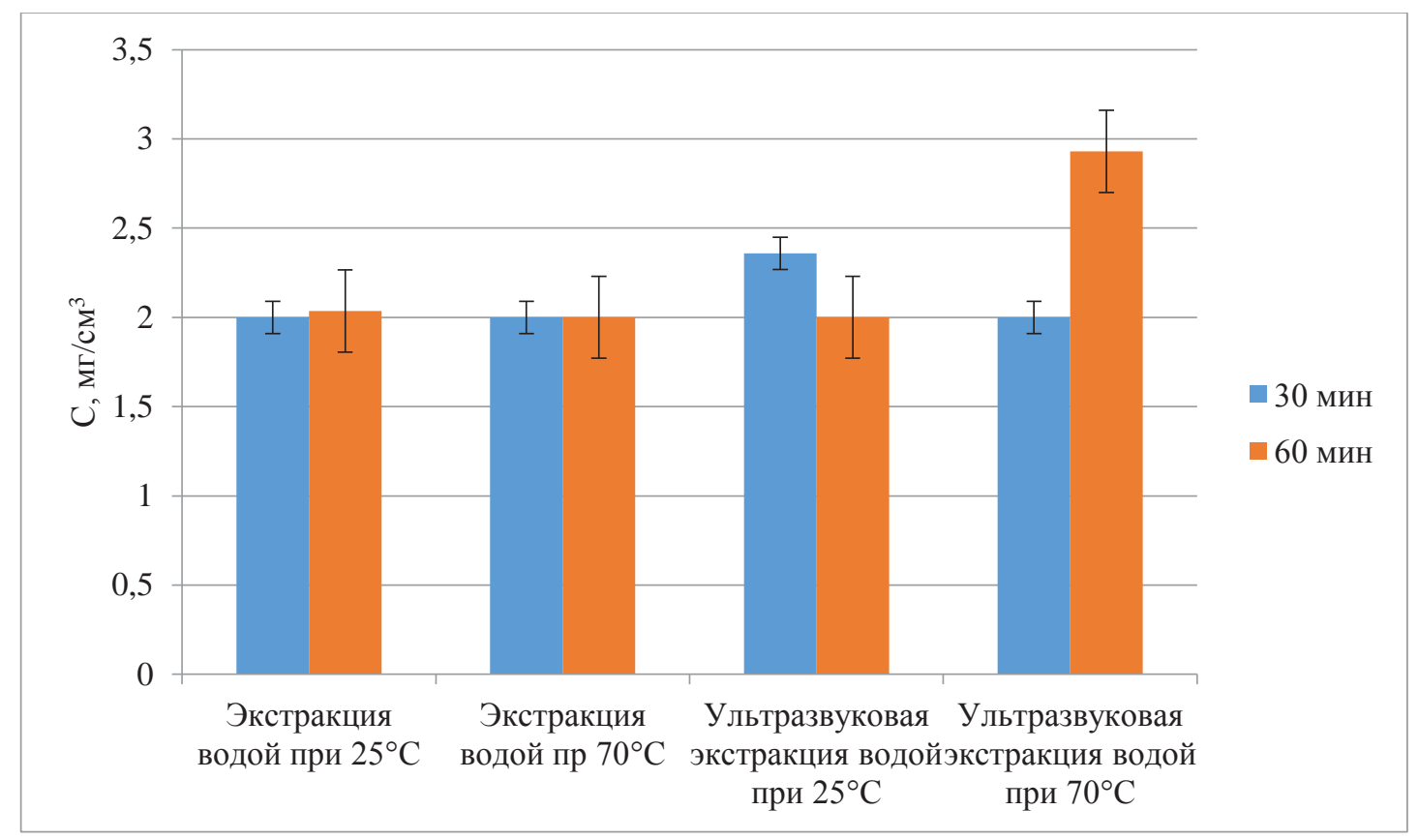

Рис. 2.18. Зависимость выхода антоцианов от метода, продолжительности и температуры экстрагирования 
Из данных рисунка 2.17 видно, что увеличение времени экстрагирования по-разному влияет на выход антоцианов и зависит от метода выделения. Максимальный выход антоцианов наблюдается при их экстрагировании водным раствором при температуре $70{ }^{\circ} \mathrm{C}$ в течение 30 мин и составляет 2,99 мг/см³. Увеличение продолжительности экстрагирования также приводит к увеличению выхода антоцианов, экстрагированных водным раствором и ультразвуком при температу-

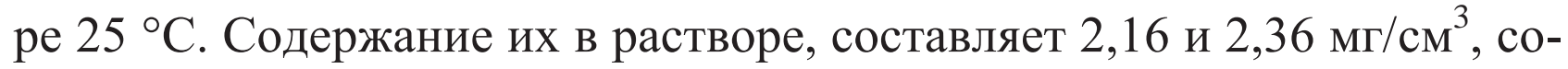
ответственно.

Изучение влияния продолжительности экстрагирования антоцианов при 5 и 30 минутах, показало увеличение их выхода при экстрагировании водным раствором при температурах 25 и $70{ }^{\circ} \mathrm{C}$ на 10 и $8 \%$, соответственно. Ультразвуковое воздействие при температуре $25{ }^{\circ} \mathrm{C}$ повышает выход антоцианов на $6 \%$.

При косвенной ультразвуковой экстракции водным раствором при $70{ }^{\circ} \mathrm{C}$ максимум выделения антоцианов наблюдается уже после 15 мин экстрагирования и составляет 2,96 мг/см³. При данном методе экстрагирования, ускорение экстракции происходит за счет акустического давления микропотоков, инициированных взрывами пузырьков, и звукового давления, генерируемого капиллярным эффектом, что приводит к ускорению диффузии растворителя в оболочки клеток и дальнейшему их разрушению, что способствует более быстрому выделению из клеток антоцианов [34].

Дальнейшее увеличение времени экстрагирования ультразвуком при температуре $70{ }^{\circ} \mathrm{C}$ в течение 30 мин приводит к замедлению процесса экстрагирования антоцианов. Содержание пигмента при дан-

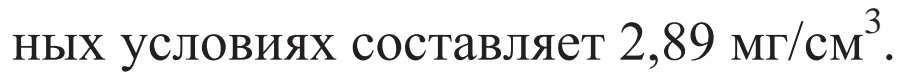

Увеличение времени выделения до 60 мин (рисунок 2.18) приводит к снижению выхода антоцианов, экстрагированных ультразвуком при комнатной температуре. При этом количество пигмента при данных способах и условиях экстракции снижается на 6 \%. Видимо, в данном случае увеличение продолжительности экстрагирования приводит к частичному разрушению антоцианов. 
Повышение температуры экстракции до $70{ }^{\circ} \mathrm{C}$ и увеличение продолжительности экстрагирования до 60 мин приводит к возрастанию выхода антоцианов на 2 \% как при экстрагировании водным раствором, так и ультразвуком Тепловой эффект и давление, создаваемое при использовании ультразвука, способствуют разрушению оболочек клеток растительного сырья и более полному выходу антоцианов в окружающую среду.

Зависимость выхода антоцианов от объекта, способа и температуры выделения представлена на рисунке 2.19. Количественное содержание антоцианов в экстрактах представлено в таблице 2.1.

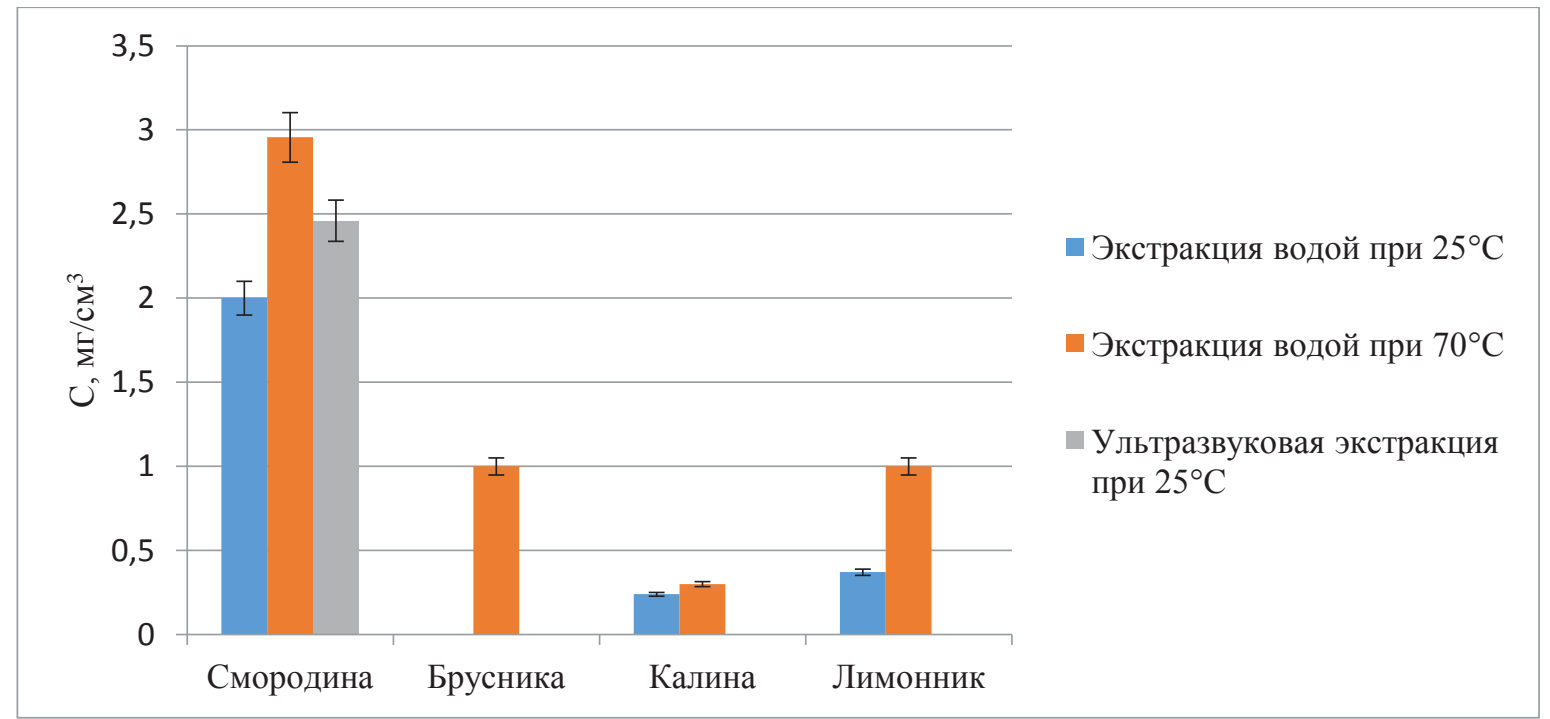

Рис. 2.19. Зависимость выхода антоцианов от объекта, способа и температуры выделения

Таблица 2.1

Содержание антоцианов в экстрактах

\begin{tabular}{|l|c|c|c|}
\hline \multirow{2}{*}{$\begin{array}{c}\text { Наименование } \\
\text { сырья }\end{array}$} & \multicolumn{3}{|c|}{ Содержание антоцианов, мг/см ${ }^{3}$} \\
\cline { 2 - 4 } & $\begin{array}{c}\text { Экстрагирование } \\
\text { водой при } \\
\text { температуре }\end{array}$ & $\begin{array}{c}\text { Экстрагирование } \\
\text { водой при } \\
\text { температуре }\end{array}$ & $\begin{array}{c}\text { Ультразвуковая } \\
\text { экстракция водой } \\
\text { при температуре }\end{array}$ \\
\hline Смородина & $2,17 \pm 0,22$ & $2,95 \pm 0,36$ & $25^{\circ} \mathrm{C}$ \\
\hline Брусника & $0,60 \pm 0,24$ & $1,13 \pm 0,26$ & $2,46 \pm 0,24$ \\
\hline Калина & $0,24 \pm 0,15$ & $0,30 \pm 0,09$ & $0,73 \pm 0,13$ \\
\hline Лимонник & $0,37 \pm 0,10$ & $1,43 \pm 0,14$ & $0,26 \pm 0,10$ \\
\hline
\end{tabular}


Из рисунка видно, что количество антоцианов, выделенных из ягод Дальневосточного региона зависит от способа и температуры выделения. Наибольшее содержание пигмента при всех способах выделения определено в черной смородине. В ягодах лимонника, брусники и калины его содержание значительно меньше. При экстрагировании ягод смородины, брусники, калины и лимонника водным раствором при температуре $25^{\circ} \mathrm{C}$ содержание антоцианов, выделенных из данных объектов, составляет $2,17,0,60,0,24$ и

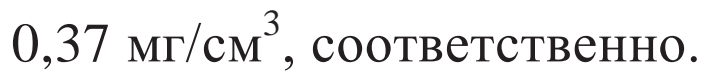

Повышение температуры до $70{ }^{\circ} \mathrm{C}$ способствует увеличению экстрагирования антоцианов водным раствором из всех исследуемых видов ягодного сырья. Данный способ экстракции повышает выход пигмента из ягод черной смородины, брусники, калины и лимонника на 27, 47, 20 и $74 \%$, соответственно.

Ультразвуковая экстракция способствует экстрагированию антоцианов из ягодного сырья, такого как смородина и брусника, выход его повышается на 22 и $18 \%$, соответственно. Ультразвуковая экстракция ягод калины и лимонника приводит к незначительному увеличению выхода антоцианов. При ультразвуковой экстракции ягод смородины, брусники, калины и лимонника водным раствором при температуре $25{ }^{\circ} \mathrm{C}$ содержание антоцианов, выделенных из данных объектов, составляет 2,460, 0,736, 0,262 и 0,422 мг/ $\mathrm{cm}^{3}$, соответственно.

Таким образом, использование ультразвука для экстрагирования позволяет увеличить выход антоцианов. Ультразвуковая экстракция при температуре $25{ }^{\circ} \mathrm{C}$ в течение 30 минут позволяет увеличить выход пигмента на $22 \%$. Повышение температуры ультразвуковой экстракции до $70{ }^{\circ} \mathrm{C}$ позволяет сократить время экстрагирования до 15 мин.

Зависимость выхода антоцианов от времени экстрагирования и вида экстрагента представлена на рисунке 2.20.

Из представленных данных видно, что продолжительность экстрагирования по-разному влияет на выход антоцианов и зависит от способа выделения и природы экстрагента. Наиболее полное извле- 
чение антоцианов наблюдается в результате его экстракции 95 \% этанолом. Максимальный выход антоцианов достигается после 25 мин

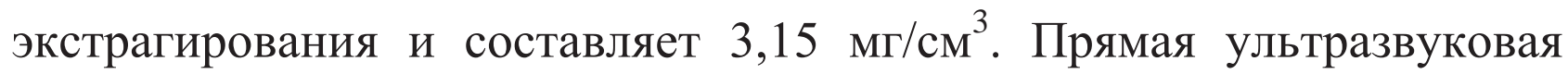
экстракция 95 \% этанолом незначительно снижает выход антоцианов, при этом максимальное его выделение достигается за 20 мин экстрагирования и составляет $2,97 \mathrm{Mг} / \mathrm{cm}^{3}$.

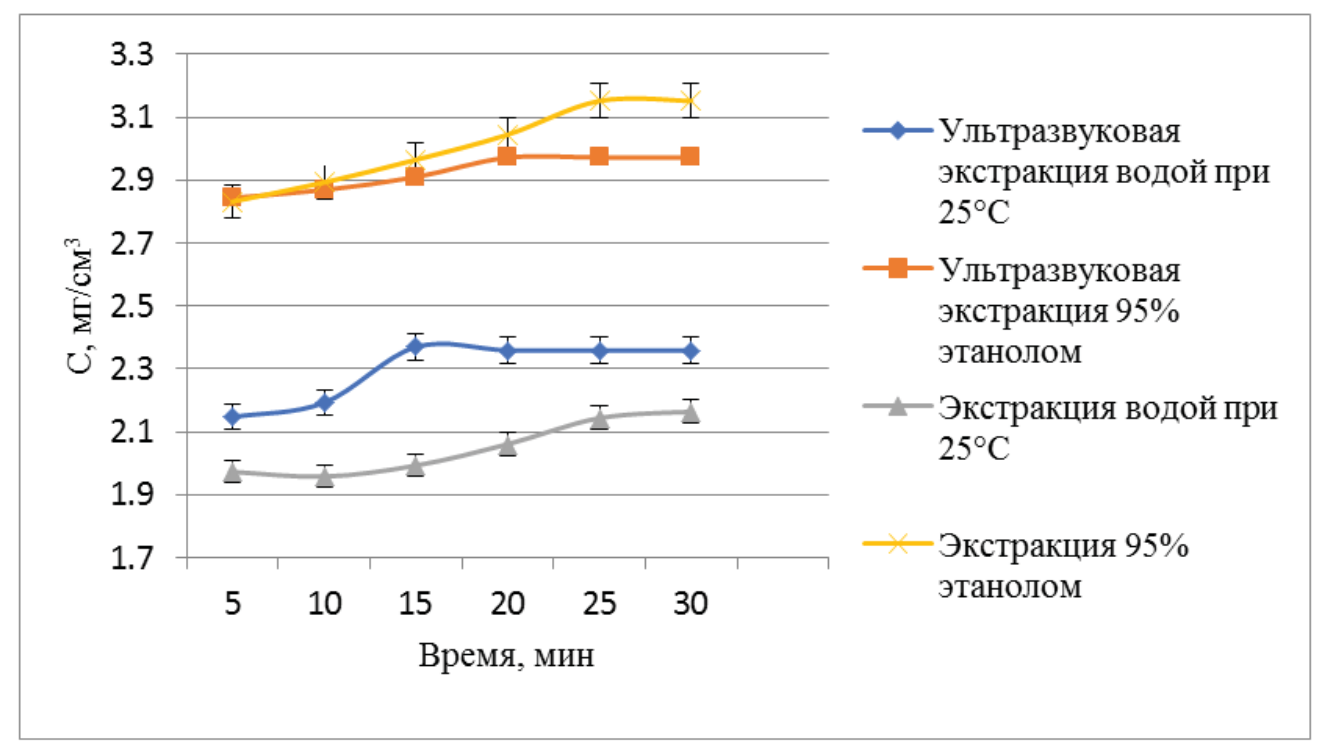

Рис. 2.20. Зависимость выхода антоцианов от времени экстрагирования и вида экстрагента

Использование воды в качестве экстрагента, а также ультразвуковая экстракция водным раствором значительно снижают выход антоцианов. Выход пигмента при данных способах экстракции снижается на 30 и $25 \%$, соответственно. При этом максимальный выход антоцианов достигается при ультразвуковой экстракции водным рас-

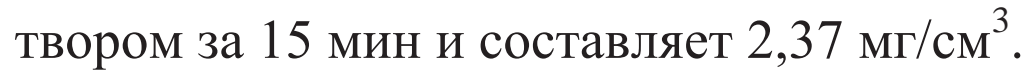

Таким образом, применение ультразвука для выделения антоцианов позволяет сократить время их экстрагирования до 20 мин с использованием в качестве экстрагента 95 \% этанол и до 15 мин в водном растворе.

Зависимости выхода антоцианов от способа ультразвуковой экстракции, а также частоты и мощности ультразвуковых колебаний представлены на рисунках 2.21 и 2.22. 


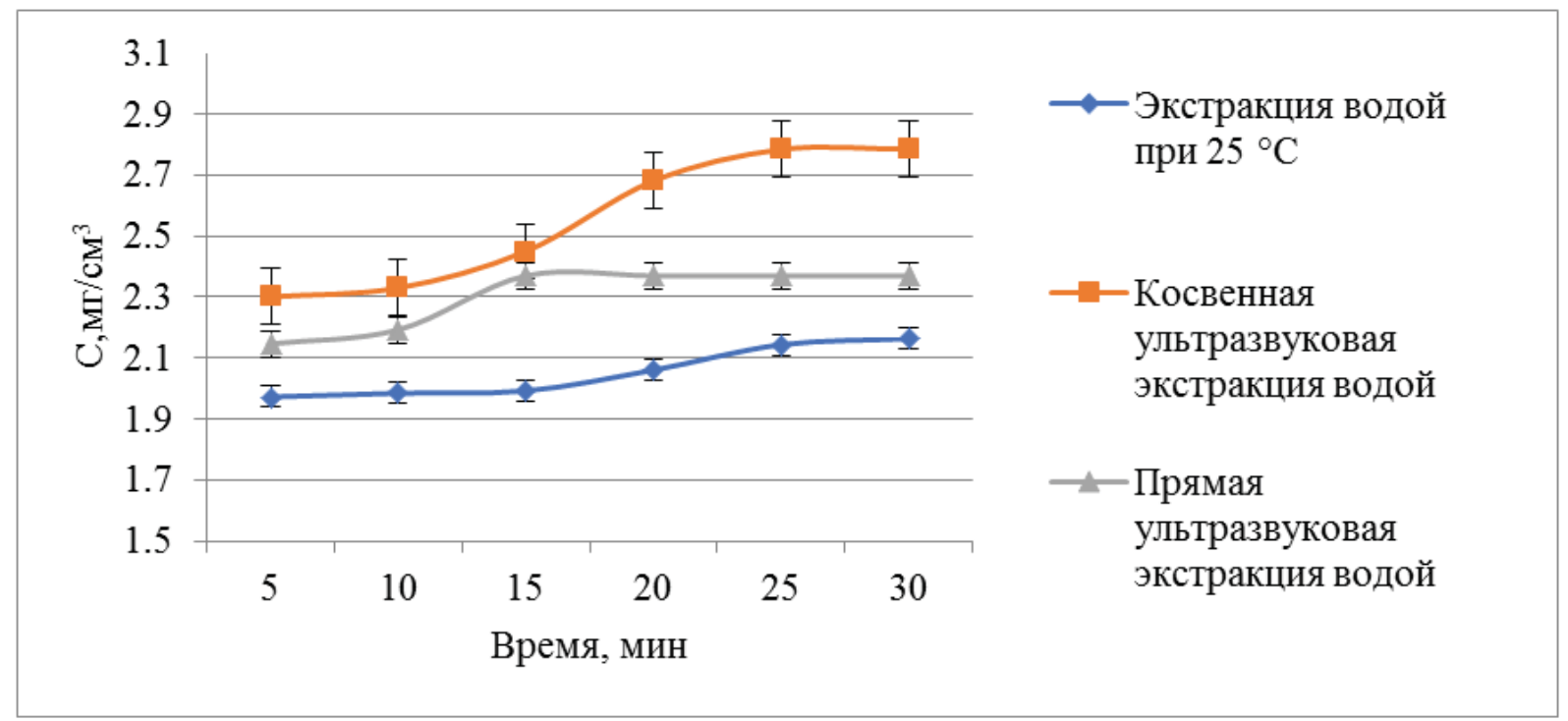

Puc. 2.21. Зависимость выхода антоцианов при водной экстракции от частоты и мощности воздействия ультразвуковых колебаний

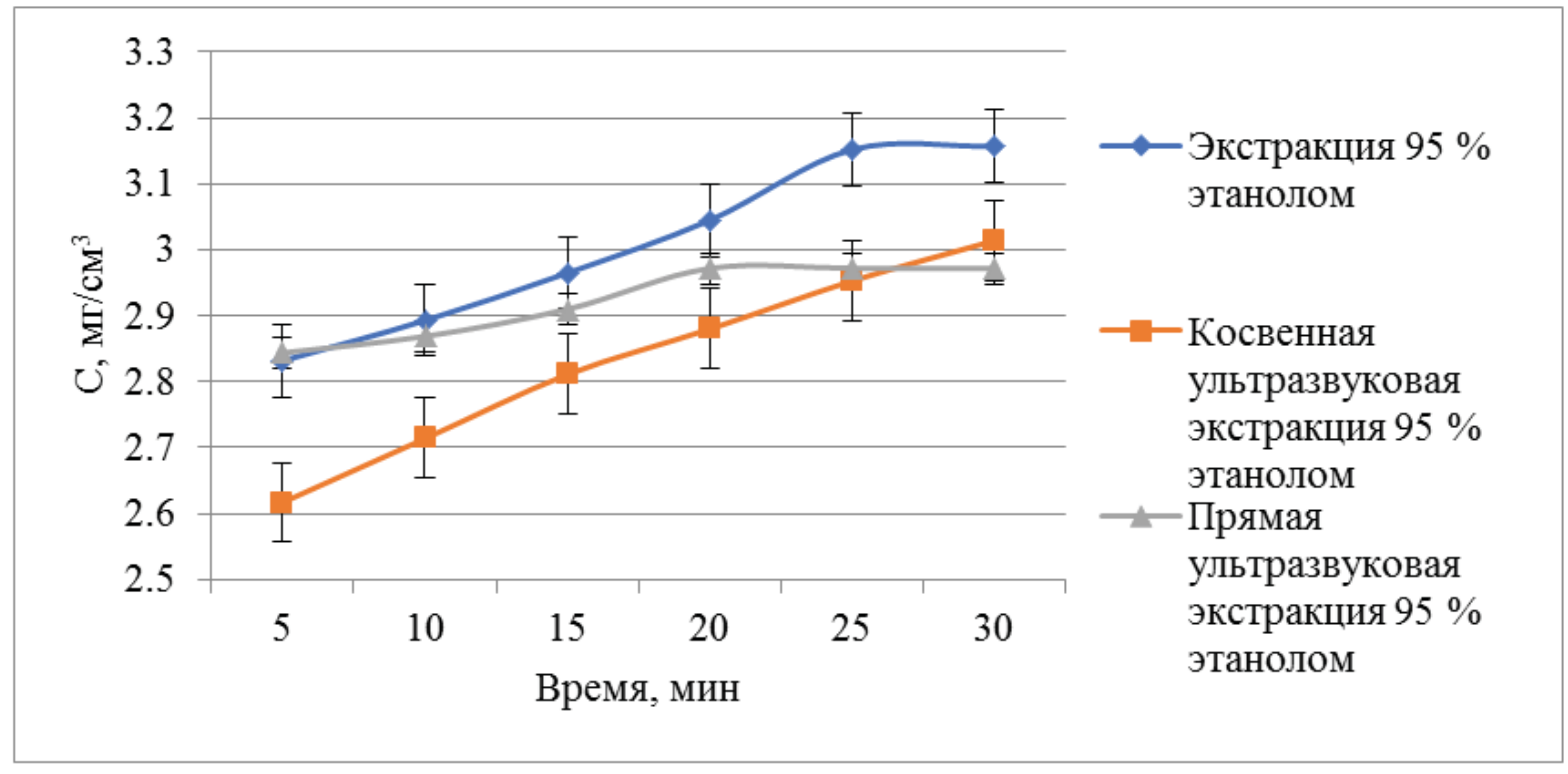

Puc. 2.22. Зависимость выхода антоцианов при спиртовой экстракции от частоты и мощности воздействия ультразвуковых колебаний

Из представленных результатов видно, что способ ультразвуковой экстракции, а также частота и мощность воздействия прибора оказывают влияние на выход антоцианов как при ультразвуковой экстракции водным раствором (рисунок 2.21), так и 95 \% этанолом (рисунок 2.22).

Максимальный выход антоцианов наблюдается при использовании ультразвуковой ванны с частотой воздействия 35 кГц и мощно- 
стью 80 Вт для ультразвуковой экстракции водным раствором и $95 \%$

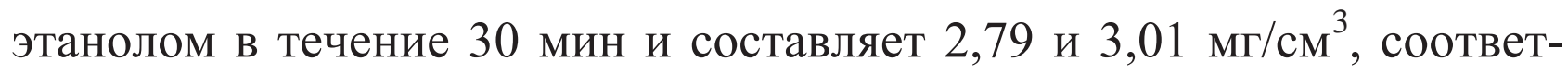
ственно. Использование ультразвукового гомогенизатора с частотой и мощностью воздействия меньшей, чем у ультразвуковой ванны, снижает выход антоцианов. Однако его использование позволяет сократить продолжительность экстрагирования антоцианов водным раствором и 95 \% этанолом. Наиболее полно антоцианы при использовании ультразвукового гомогенизатора и водного раствора в качестве экстрагента извлекается за 15 мин. Содержание антоцианов, экстрагированных водным раствором при частоте воздействия 20 кГц и

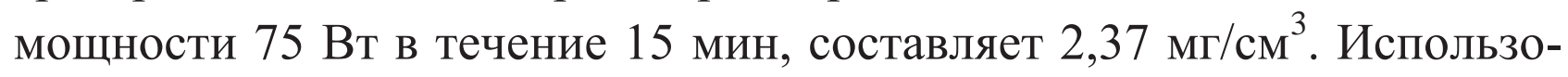
вание 95 \% этанола в качестве экстрагента при данном способе экстракции позволяет сократить время экстрагирования до 20 мин. Содержание антоцианов, экстрагированных 95 \% этанолом при частоте

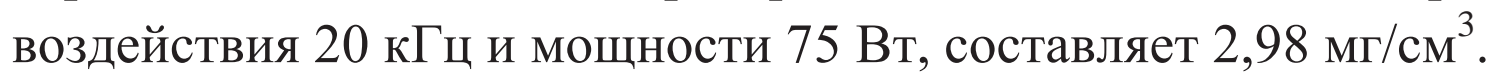

Таким образом, способ ультразвукового воздействия, а также частота и мощность ультразвуковых колебаний оказывают существенное влияние на выход антоцианов из ягодного сырья. Частота ультразвукового воздействия 35 кГц и мощность 80 Вт позволяет наиболее полно выделять антоцианы в течение 30 мин. Видимо, более мощное воздействие ультразвуковой волны через жидкость приводит к акустической кавитации, способствующей более полному разрушению клеточных стенок и, соответственно, выходу антоцианов в окружающую среду. Снижение частоты воздействия до 20 кГц и мощности 75 Вт позволяет сокращать время экстрагирования до 15 мин водным раствором и 20-ти мин 95 \% этанолом.

Для наглядного описания зависимости выхода антоцианов были представлены результаты в виде трехмерных графиков поверхности отклика, которые иллюстрируют влияние способа извлечения, времени и температуры экстрагирования на выделение антоцианов из ягодного сырья. На рисунке 2.23 (а-в) показаны поверхности отклика, иллюстрирующие зависимость выхода антоцианов от времени и температуры экстрагирования. 

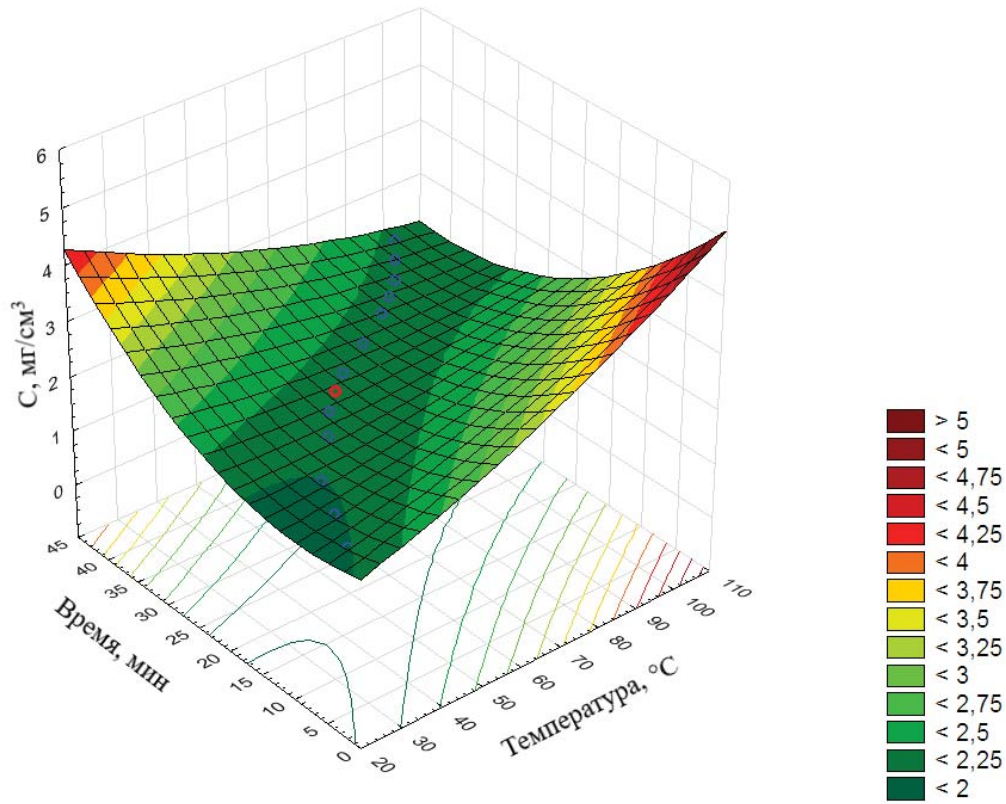

a)
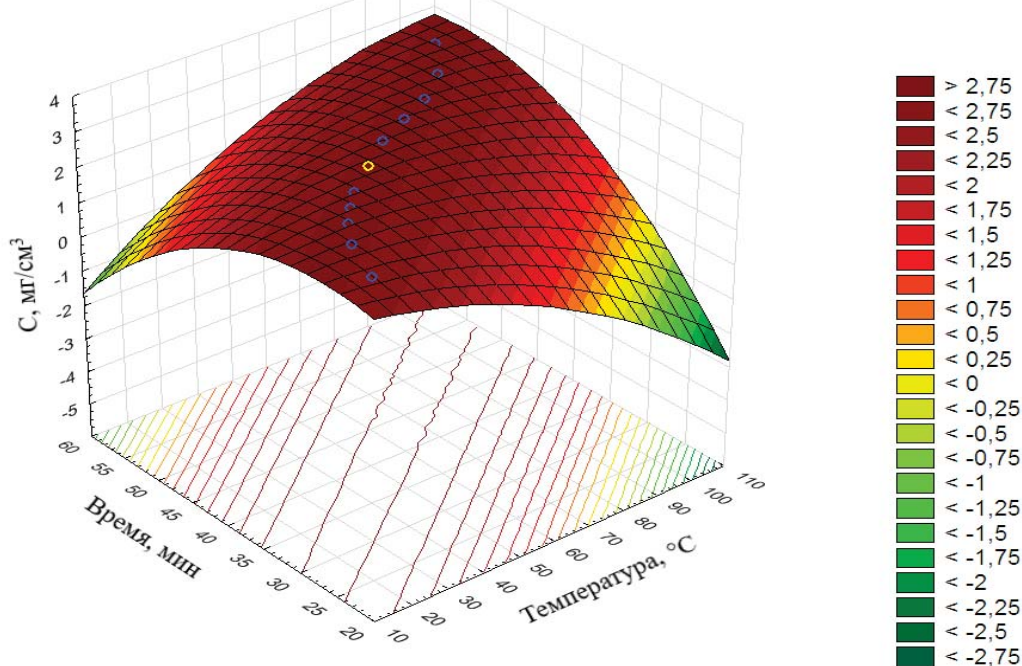

б) 


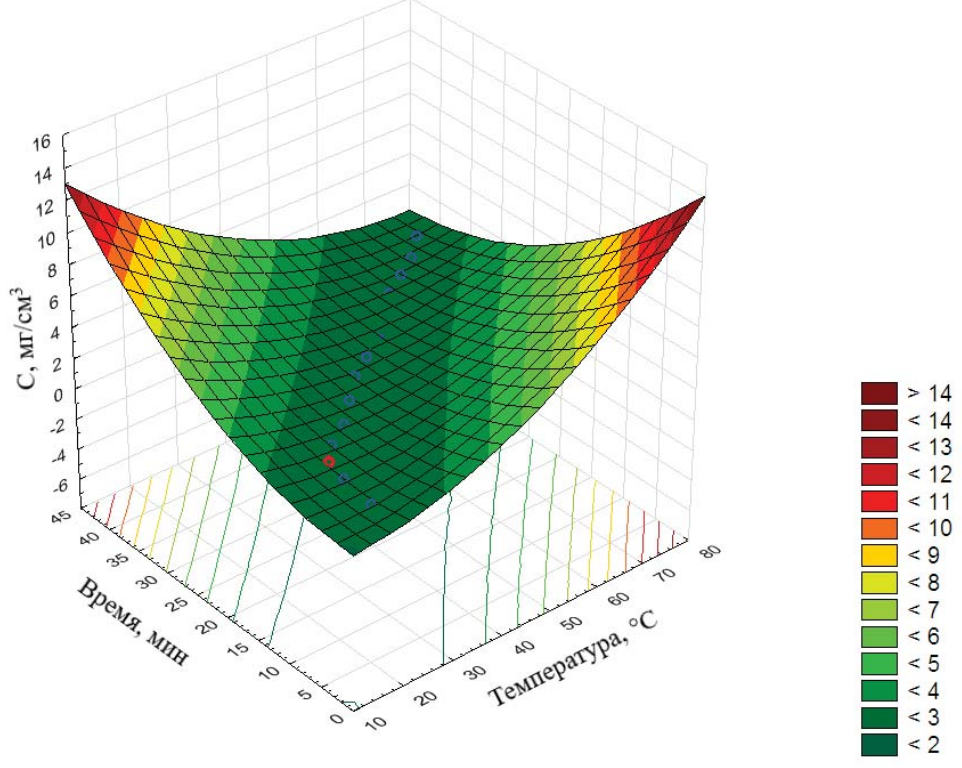

в)

Puc. 2.23. Поверхности отклика, иллюстрирующие зависимость выхода антоцианов от времени и температуры экстрагирования:

a) содержание антоцианов в растворе при их экстрагировании водой, мг $/ \mathrm{cm}^{3}$, смоделированное с помощь уравнения регрессии:

$$
C_{1}=1,6549+0,0159 x-0,0086 y+0,0001 x^{2}-0,0013 x y+0,0019 y^{2},
$$

б) содержание антоцианов в водном растворе при косвенной ультразвуковой экстракции, мг $/ \mathrm{cm}^{3}$, смоделированное с помощь уравнения регрессии:

$$
C_{2}=0,4541-0,0586 x+0,1949 y-0,0004 x^{2}+0,0025 x y-0,0041 y^{2},
$$

в) содержание антоцианов в водном растворе при прямой ультразвуковой экстракции, мг $/ \mathrm{cm}^{3}$, смоделированное с помощь уравнения регрессии:

$$
C_{3}=2,0283-0,0281 x+0,0752 y+0,0022 x^{2}-0,0073 x y+0,0054 y^{2}
$$

Полученные трехмерные графики показали, что все три переменные оказывают значимое положительное влияние на выделение антоцианов из ягодного сырья. На представленных графиках четко видны либо гребни, либо углубления, свидетельствующие о наиболее рациональных условиях экстрагирования, позволяющие предсказать оптимальные режимы для извлечения антоцианов. Оптимальными режимами для извлечения антоцианов являются их экстрагирование с помощью косвенной ультразвуковой экстракции при температуре $25{ }^{\circ} \mathrm{C}$ в течение 30 мин, прямая ультразвуковая экстракция при температуре $25^{\circ} \mathrm{C}$ в течение 15 мин и извлечение водным раствором при температуре $70{ }^{\circ} \mathrm{C}$ в течение 30 мин. 


\section{6. Оптимизация технологий получения антоцианов \\ из вторичных продуктов переработки \\ ягодного сырья}

Вторичные продукты переработки ягодного сырья - выжимки состоят из неоднородной смеси кожуры (перикарпия), семян и пульпы, которые составляют около 20-40\% от веса ягоды до переработки. После удаления соковой составляющей ягод в выжимках остаются такие ценные биологически активные вещества как клетчатка, гемицеллюлоза, пектиновые вещества, олигосахариды, органические кислоты витамины, минеральные вещества и полифенольные соединения. В состав полифенольных соединений, остающихся в выжимках, входят антоцианы.

В данном разделе рассмотрена возможность использования вторичных продуктов переработки ягод (выжимок) в качестве источника антоцианов, а также предложены оптимальные условия их выделения.

Содержание выжимок в ягодах черной смородины, полученных путем отделения сока, представлено на рисунке 2.24.

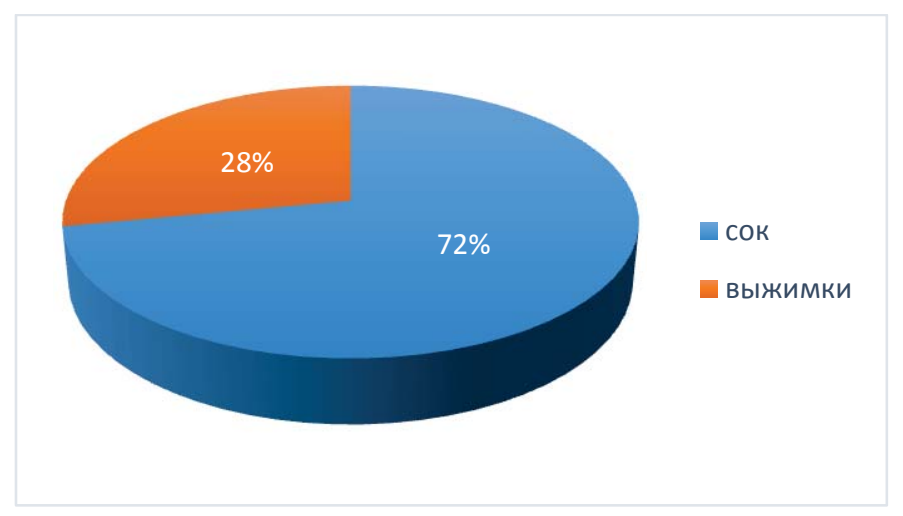

Puс. 2.24. Содержание выжимок в ягодах черной смородины

Из рисунка видно, что содержание выжимок в ягодах черной смородины составляет $28 \%$.

Содержание выжимок, полученных после экстрагирования антоцианов из ягод черной смородины представлено на рисунке 2.25. 


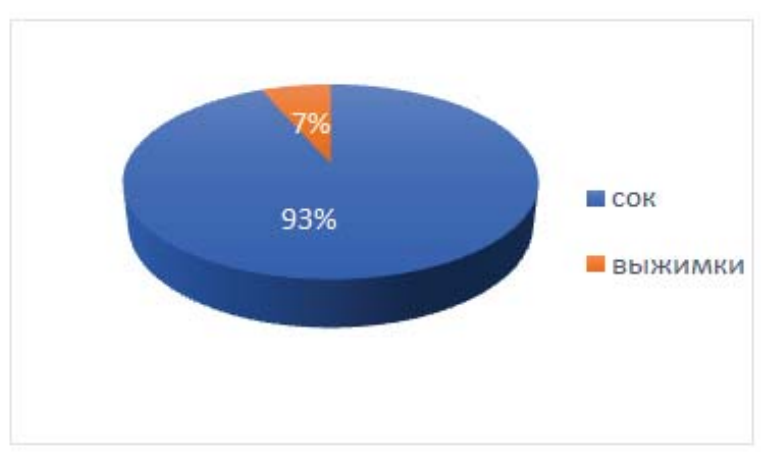

a)

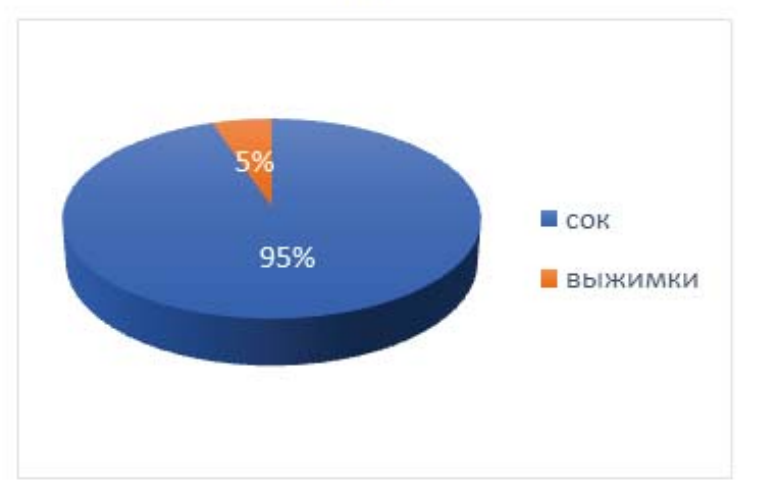

b)

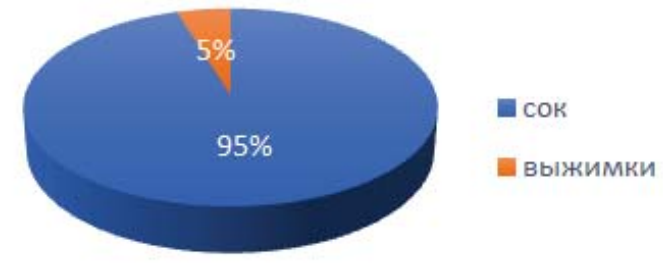

б)

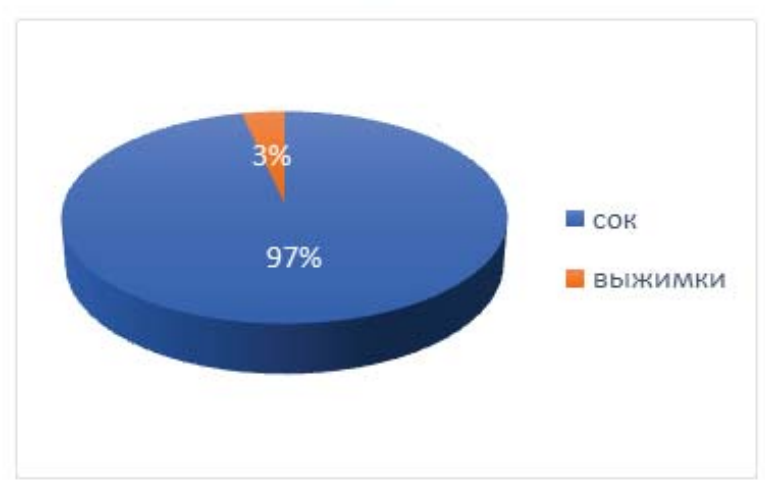

2)

Puc. 2.25. Содержание выжимок, полученных после экстрагирования антоцианов из ягод черной смородины а) экстрагирование при $25^{\circ} \mathrm{C} 30 \mathrm{мин,}$ б) экстрагирование при $65{ }^{\circ} \mathrm{C} 30$ мин, в) ультразвуковая экстракция при $25{ }^{\circ} \mathrm{C}$ 30 мин, г) ультразвуковая экстракция при $65^{\circ} \mathrm{C} 30$ мин

Из представленных результатов видно, что после выделения антоцианов из ягод количество выжимок значительно сокращается. Экстрагирование антоцианов из ягод черной смородины при темпеpaтуре $25^{\circ} \mathrm{C}$ в течение 30 мин приводит к уменьшению количества выжимок в 4,7 раз. Увеличение температуры экстрагирования до $65{ }^{\circ} \mathrm{C}$ способствует уменьшению количества выжимок в 5,6 раз. Видимо, в процессе экстрагирования антоцианов происходит переход в раствор, содержащихся в тонком наружном перикарпии, таких водорастворимых соединений как пигменты, сахара, белки и витамины.

Использование ультразвуковой экстракции для извлечения антоцианов из ягод черной смородины способствует переходу растворимых веществ из кожистого слоя в раствор. При ультразвуковой экстракции антоцианов при температуре $25^{\circ} \mathrm{C}$ происходит уменьше- 
ние количества выжимок в 5,6 раз. При повышении температуры ультразвуковой экстракции до $65^{\circ} \mathrm{C}$ количество выжимок уменьшается в 7 раз. Под действием ультразвуковых волн и кавитационного эффекта, который они производят, происходит интенсификация массопередачи и более легкий доступ растворителя к растительной клетке. При этом, распад кавитационных пузырей около стенок клеток приводит к разрушению клеточной стенки, способствуя более интенсивному проникновению внутрь клетки растворителя и, соответственно, перехода водорастворимых веществ в раствор [7]. Кроме того, под действием ультразвука возможен частичный гидролиз полисахаридов клеточных стенок перикарпия до более простых водорастворимых соединений.

С целью увеличения выхода антоцианов в работе изучалось влияние температуры на интенсивность извлечения антоцианов из выжимок черной смородины. УФ-спектры растворов антоцианов, полученных из выжимок черной смородины при различной температуре экстрагирования представлены на рисунке 2.26.

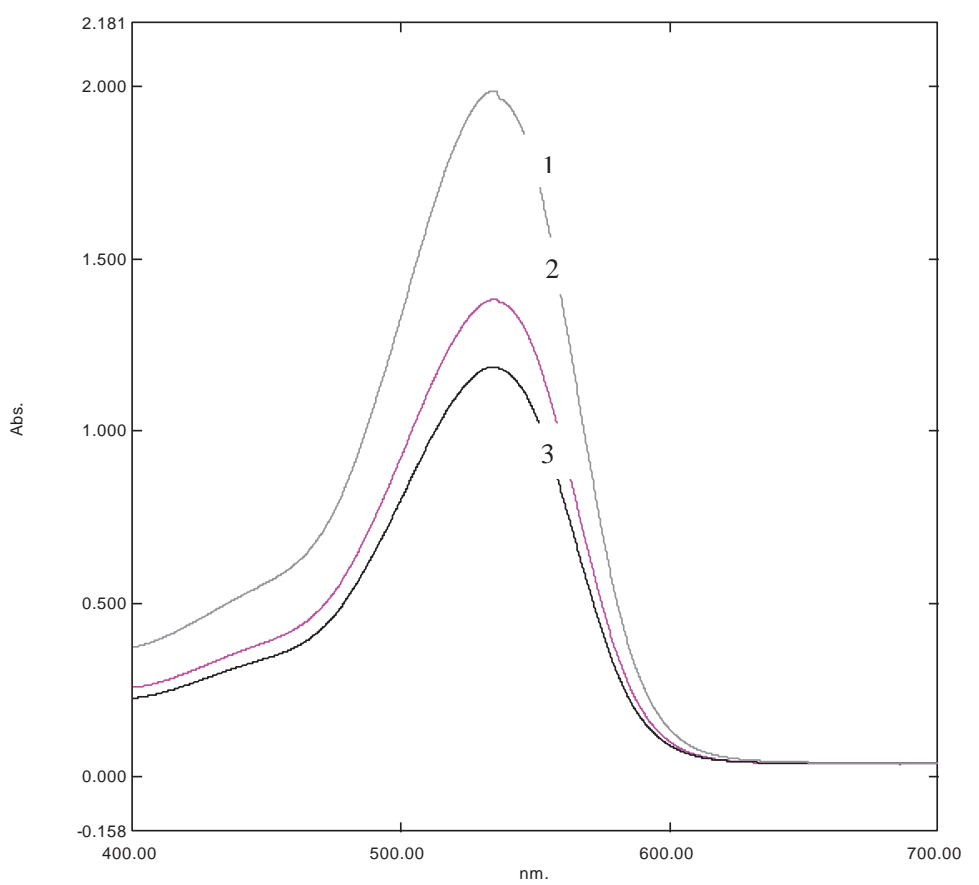

Рис. 2.26. УФ-спектры растворов антоцианов, полученных из выжимок ягод черной смородины при различной температуре экстрагирования $1.100{ }^{\circ} \mathrm{C}, 2.65^{\circ} \mathrm{C}, 3.25^{\circ} \mathrm{C}$ 
Содержание антоцианов, выделенных при $25^{\circ} \mathrm{C}, 65^{\circ} \mathrm{C}$ и $100{ }^{\circ} \mathrm{C}$ из выжимок ягод черной смородины, представлено в таблице 2.2.

Таблица 2.2

Содержание антоцианов, выделенных при $25^{\circ} \mathrm{C}, 65^{\circ} \mathrm{C}$ и $100{ }^{\circ} \mathrm{C}$ из выжимок ягод черной смородины

\begin{tabular}{|l|c|}
\hline \multicolumn{1}{|c|}{ Условия извлечения } & $\begin{array}{c}\text { Количество антоцианов в выжимках } \\
\text { ягод черной смородины, мг } / \mathrm{cm}^{3}\end{array}$ \\
\hline $25^{\circ} \mathrm{C}$ в течение 30 мин & $0,46 \pm 0,11$ \\
\hline $65^{\circ} \mathrm{C}$ в течение 30 мин & $0,73 \pm 0,23$ \\
\hline $100^{\circ} \mathrm{C}$ в течение 5 мин & $1,15 \pm 0,25$ \\
\hline
\end{tabular}

Из представленных результатов видно, что температура влияет на значения оптической плотности растворов антоцианов, выделенных из выжимок ягод черной смородины. Наиболее полно антоцианы извлекаются при температуре $100{ }^{\circ} \mathrm{C}$, их содержание составляет $1,15 \mathrm{мг} / \mathrm{cm}^{3}$. При понижении температуры экстрагирования до $65{ }^{\circ} \mathrm{C}$ количество извлекаемого пигмента уменьшается в 1,6 раз. Наименьшее извлечение антоцианов из выжимок черной смородины происходит при их экстрагировании при температуре $25{ }^{\circ} \mathrm{C}$. Содержание их в растворе составляет $0,46 \mathrm{Mг} / \mathrm{cm}^{3}$.

Таким образом, степень выделение антоцианов из выжимок черной смородины, зависит от температуры экстрагирования. Вероятно, при температурах выше $65{ }^{\circ} \mathrm{C}$, происходит денатурационные изменения белков, входящих в состав клеточных оболочек перикарпия, что способствует повышению проницаемости клеточных стенок и, соответственно, увеличению более полному выделению антоцианов из выжимок.

Поскольку способ выделения определяет выход биологически активных веществ из растительного сырья в раствор, в работе была проведена ультразвуковая экстракция антоцианов, выделенных из выжимок черной смородины. Содержание антоцианов, выделенных из выжимок черной смородины в процессе ультразвуковой экстракции, при температурах 25 и $65{ }^{\circ} \mathrm{C}$ в течение 5-30 мин представлено в таблице 2.3. 


\section{Содержание антоцианов, выделенных из выжимок черной} смородины в процессе ультразвуковой экстракции

\begin{tabular}{|c|c|c|}
\hline \multirow{2}{*}{$\begin{array}{c}\text { Время } \\
\text { экстрагирования, }\end{array}$} & \multicolumn{2}{|c|}{ Содержание антоцианов } \\
\cline { 2 - 3 } мин & в выжимках черной смородины, мг/см ${ }^{3}$ \\
\cline { 2 - 3 } & ультразвуковая экстракция & ультразвуковая экстракция \\
& при & при \\
\hline 5 & $25^{\circ} \mathrm{C}$ & $65^{\circ} \mathrm{C}$ \\
\hline 10 & $0,68 \pm 0,12$ & $0,78 \pm 0,22$ \\
\hline 15 & $0,88 \pm 0,18$ & $0,89 \pm 0,15$ \\
\hline 20 & $1,11 \pm 0,17$ & $1,34 \pm 0,13$ \\
\hline 25 & $1,24 \pm 0,21$ & $1,48 \pm 0,19$ \\
\hline 30 & $1,42 \pm 0,16$ & $1,13 \pm 0,16$ \\
\hline & $1,41 \pm 0,13$ & $1,08 \pm 0,12$ \\
\hline
\end{tabular}

Из данных таблиц 2.2 и 2.3 видно, что ультразвуковая экстракция способствует извлечению антоцианов из выжимок черной смородины. Наибольшее количество антоцианов из выжимок черной смородины выделяется при их ультразвуковом экстрагировании при температурах $25{ }^{\circ} \mathrm{C}$ в течение 25 мин и при $65{ }^{\circ} \mathrm{C}$ в течение 15 мин. Coдержание антоцианов, перешедших в раствор при данных условиях

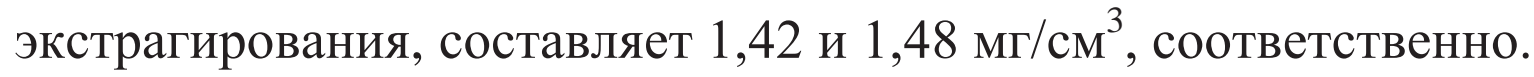

Дальнейшее увеличение времени экстрагирования ультразвуком при температурах $25{ }^{\circ} \mathrm{C}$ в течение 30 мин и $65{ }^{\circ} \mathrm{C}$ в течение 25 мин приводит к замедлению процесса экстрагирования антоцианов. Содержание пигмента при данных условиях составляет 1,22 и $1,13 \mathrm{мг} / \mathrm{cm}^{3}$, соответственно.

Для наглядного описания зависимости выхода антоцианов из ягодных выжимок были представлены результаты в виде трехмерного графика поверхности отклика, показывающего оптимальные условия выделения антоцианов из ягодных выжимок при ультразвуковой экстракции при изменении времени и температуры экстрагирования. На рисунке 2.27 представлена поверхность отклика, иллюстрирующая зависимость выхода антоцианов из ягодных выжимок при ультразвуковой экстракции от времени и температуры экстрагирования. 


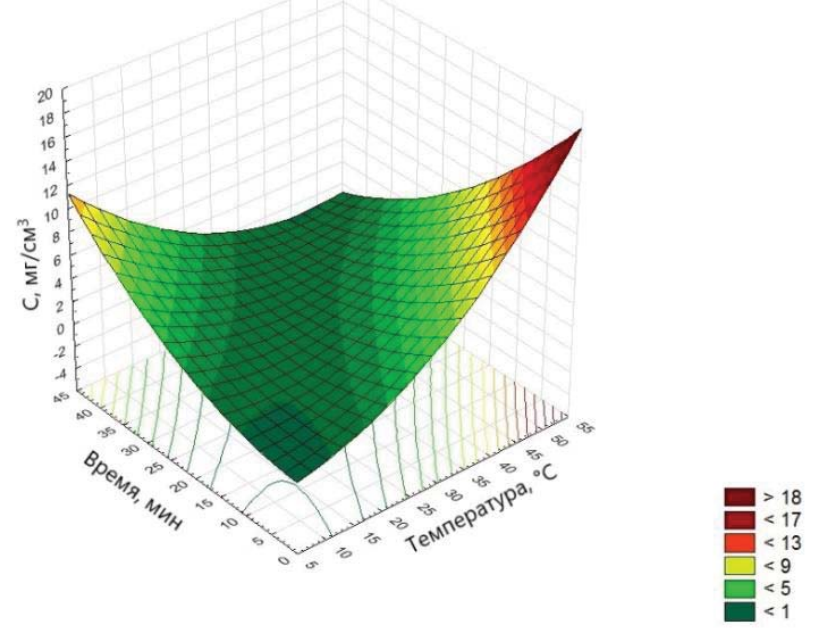

Рис. 2.27. Поверхность отклика, иллюстрирующая зависимость выхода антоцианов из ягодных выжимок при ультразвуковой экстракции от времени и температуры экстрагирования

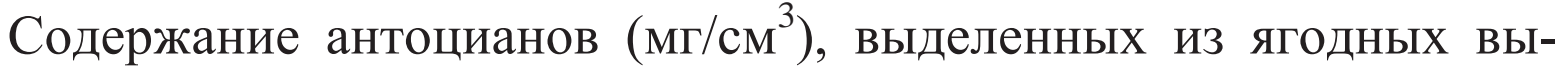
жимок при ультразвуковой экстракции, смоделировано с помощь уравнения регрессии:

$$
C=0,0104+0,0227 x+0,0753 y+0,0058 x^{2}-0,0127 x y+0,0052 y^{2} .
$$

Полученный трехмерный график показывает, что все три переменные оказывают значимое положительное влияние на выделение антоцианов из ягодного сырья. На представленном графике четко видно углубление, свидетельствующие о наиболее рациональных условиях экстрагирования, позволяющих предсказать оптимальные режимы для извлечения антоцианов. Оптимальным режимом для извлечения антоцианов из ягодных выжимок является их экстрагирование ультразвуком при температуре $25^{\circ} \mathrm{C}$ в течение 25 мин.

Таким образом, анализ полученных результатов показал возможность использования выжимок черной смородины в качестве источника биологически активных соединений - антоцианов и пектиновых веществ. Наиболее оптимальным способом для извлечения антоцианов из выжимок черной смородины является ультразвуковая экстракция. 


\section{7. Идентификация антоцианидинов, содержащихся \\ в растворах антоцианов, полученных при разных условиях экстрагирования}

Идентификацию антоцианидинов методом высокоэффективной жидкостной хроматографии и МC-МС масс-спектрометрии проводили в пяти образцах антоцианов, полученных при разных условиях экстрагирования. Условия экстрагирования образцов антоцианов из ягод черной смородины и содержание в них антоцианов представлены в таблице 2.4 .

Таблицุа 2.4

\section{Условия экстрагирования образцов \\ и содержание в них антоцианов}

\begin{tabular}{|c|l|c|}
\hline $\begin{array}{c}\text { № об- } \\
\text { разца }\end{array}$ & \multicolumn{1}{|c|}{ Способ экстрагирования } & $\begin{array}{c}\text { Содержание } \\
\text { антоцианов } \\
\text { мг/см }\end{array}$ \\
\hline 1 & $\begin{array}{l}\text { Экстрагирование } 30 \text { мин, при температуре } \\
25^{\circ} \mathrm{C}\end{array}$ & $2,96 \pm 0,29$ \\
\hline 2 & $\begin{array}{l}\text { Экстрагирование } 30 \text { мин при температуре } \\
75^{\circ} \mathrm{C}\end{array}$ & $3,73 \pm 0,25$ \\
\hline 3 & $\begin{array}{l}\text { Экстрагирование } 5 \text { мин при температуре } \\
100{ }^{\circ} \mathrm{C}\end{array}$ & $4,09 \pm 0,33$ \\
\hline 4 & $\begin{array}{l}\text { Косвенная ультразвуковая экстракция } 30 \\
\text { мин при температуре } 25^{\circ} \mathrm{C}\end{array}$ & $3,43 \pm 0,21$ \\
\hline 5 & $\begin{array}{l}\text { Прямая ультразвуковая экстракция } 15 \text { мин } \\
\text { при температуре } 25^{\circ} \mathrm{C}\end{array}$ & $3,98 \pm 0,32$ \\
\hline
\end{tabular}

Из представленных в таблице 2.4 результатов видно, что наиболее полно антоцианы извлекаются из ягод черной смородины при температурах $75^{\circ} \mathrm{C}$ и $100{ }^{\circ} \mathrm{C}$ в течение 30 мин (образцы 2 и 3) и обработке в ультразвуковом гомогенизаторе в течение 15 мин (образец 5). Содержание антоцианов в данных образцах, составляет 3,73, 4,09 и

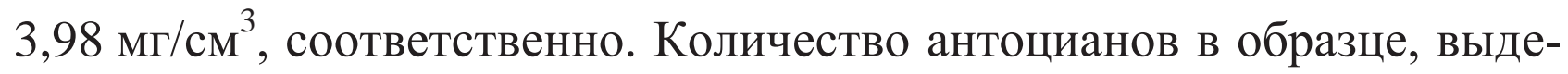
ленном с помощью ультразвуковой бани (образец 4), составляет 3,43 мг/см ${ }^{3}$. Наименьшее содержание антоцианов наблюдается в об- 
разце, экстрагированном при температуре $25^{\circ} \mathrm{C}$ в течение 30 мин, оно составляет $2,96 \mathrm{mг} / \mathrm{cm}^{3}$.

Профили элюции образцов антоцианов, экстрагированных различными способами, с выделенными пиками целевых аналитов, в частности антоцианидинов, представлены на рисунках 2.28-2.32.

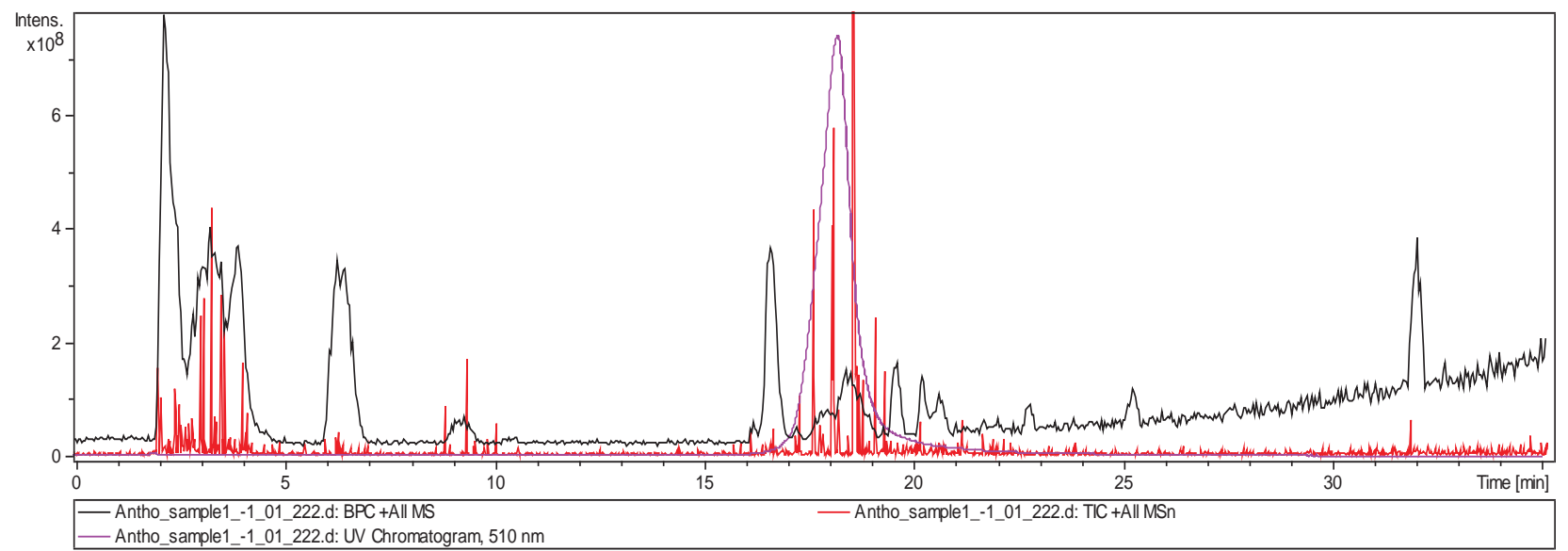

Puc. 2.28. Профиль элюции образца 1 антоцианов (черная линия - график интенсивности сигнала положительных ионов; красная линия - интенсивность фрагментации положительных ионов, фиолетовая линия - абсорбция при длине волны 510 нм

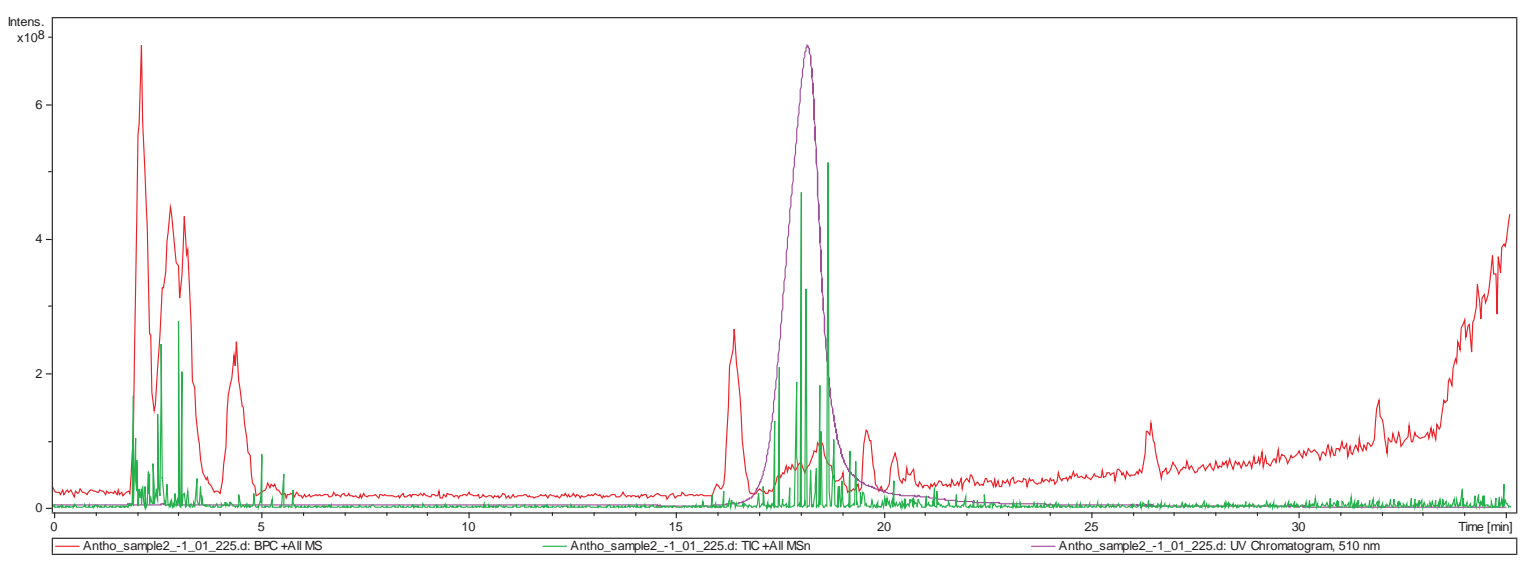

Puc. 2.29. Профиль элюции образца 2 антоцианов (красная линия - график интенсивности сигнала положительных ионов; зеленая линия - интенсивность фрагментации положительных ионов, фиолетовая линия - абсорбция при длине волны 510 нм 


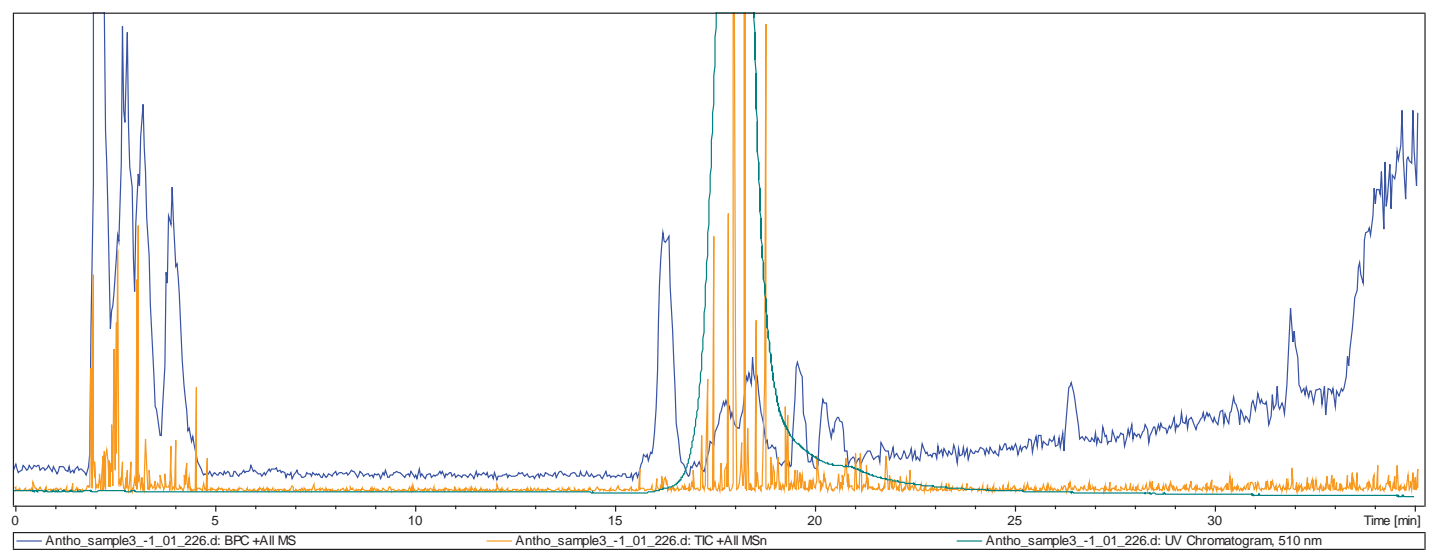

Puc. 2.30. Профиль элюции образца 3 антоцианов (синяя линия - график интенсивности положительных ионов; желтая линия - интенсивность фрагментации положительных ионов, зеленая линия - абсорбция при длине волны 510 нм

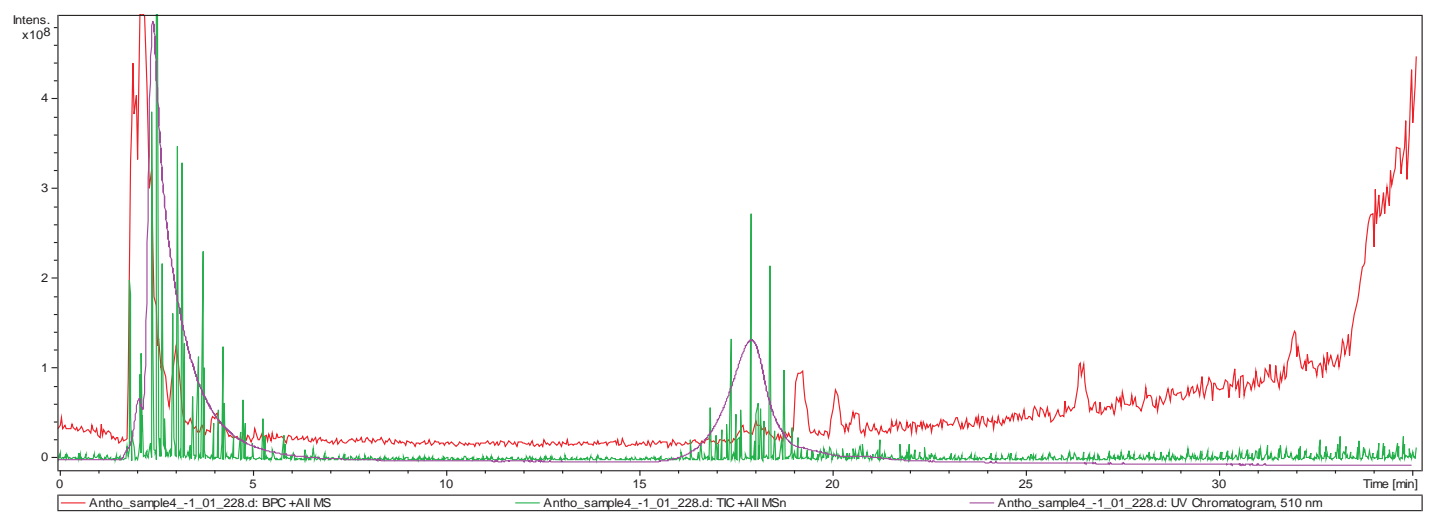

Puc. 2.31. Профиль элюции образца 4 антоцианового пигмента (красная линия - график интенсивности положительных ионов; зеленая линия интенсивность фрагментации положительных ионов, фиолетовая линия абсорбция при длине волны 510 нм

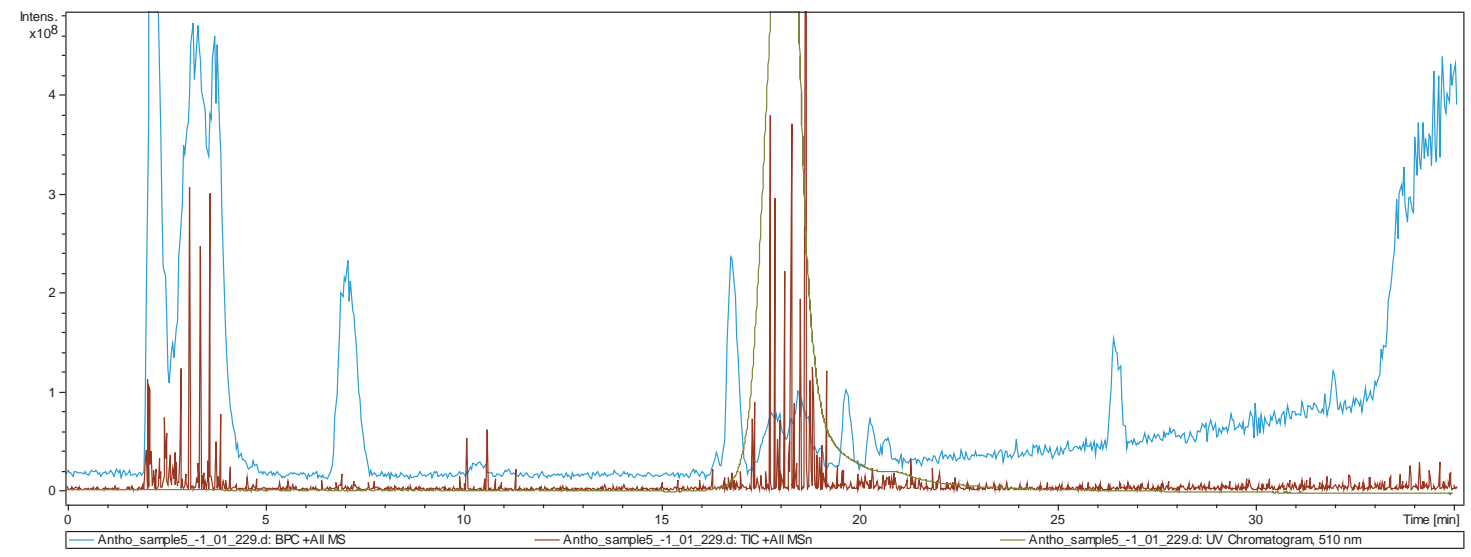

Puc. 2.32. Профиль элюции образца 5 антоцианов

(синяя линия - график интенсивности положительных ионов; коричневая линия интенсивность фрагментации положительных ионов, черная линия абсорбция при длине волны 510 нм 
Из представленных результатов видно, что во всех образцах антоцианов в области 510 нм обнаруживаются антоцианидины.

Масс-спектры образцов антоцианов, выделенных различными способами, представлены на рисунках 2.33-2.37 и в Приложении А. Данные об идентифицированных антоцианидинах в образцах антоцианов, а также молекулярные массы целевых аналитов и сопутствующие ионы представлены в таблице 2.5 .

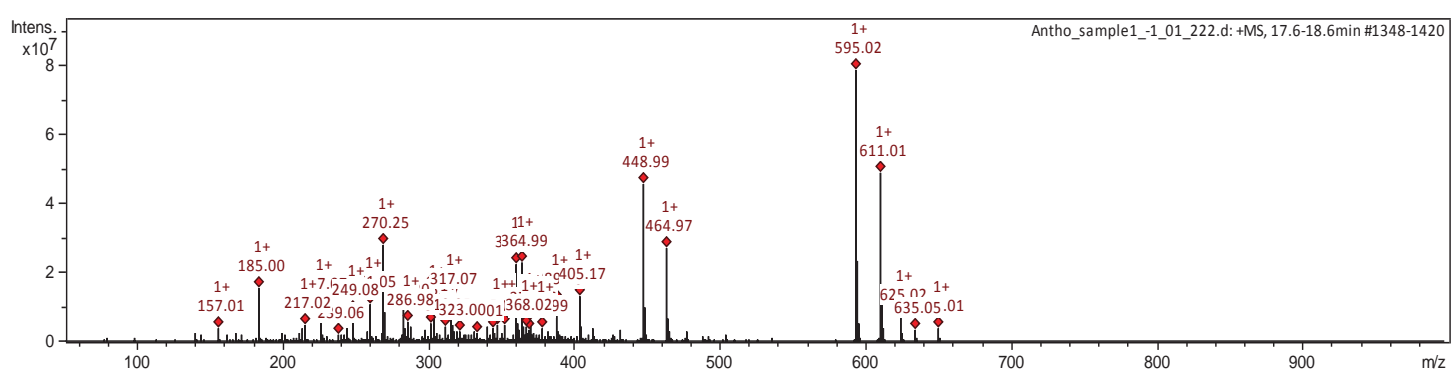

Pис. 2.33. Масс-спектр пиков антоцианидинов из образца 1

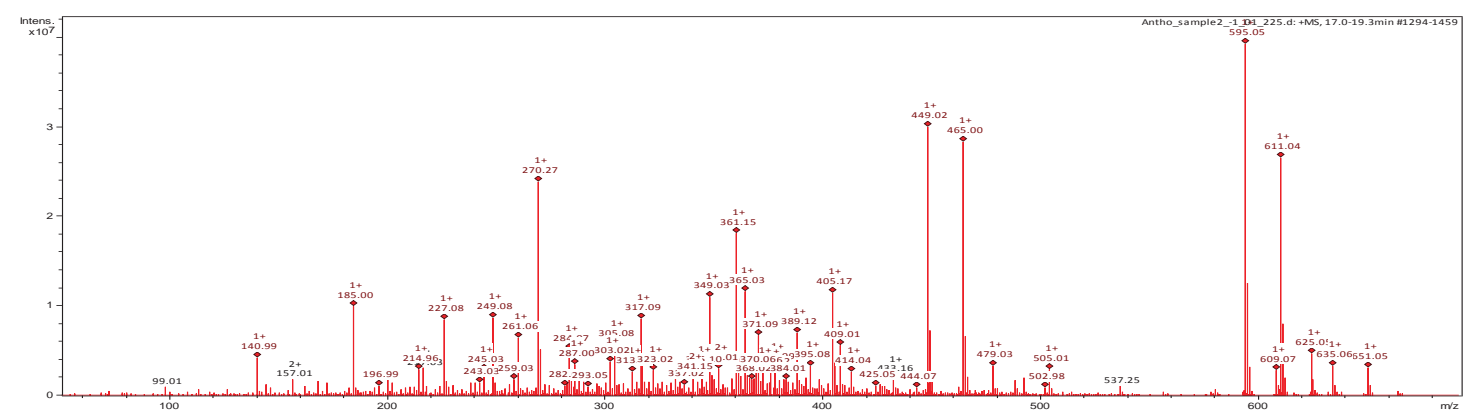

Puc. 2.34. Масс-спектр пиков антоцианидинов из образца 2

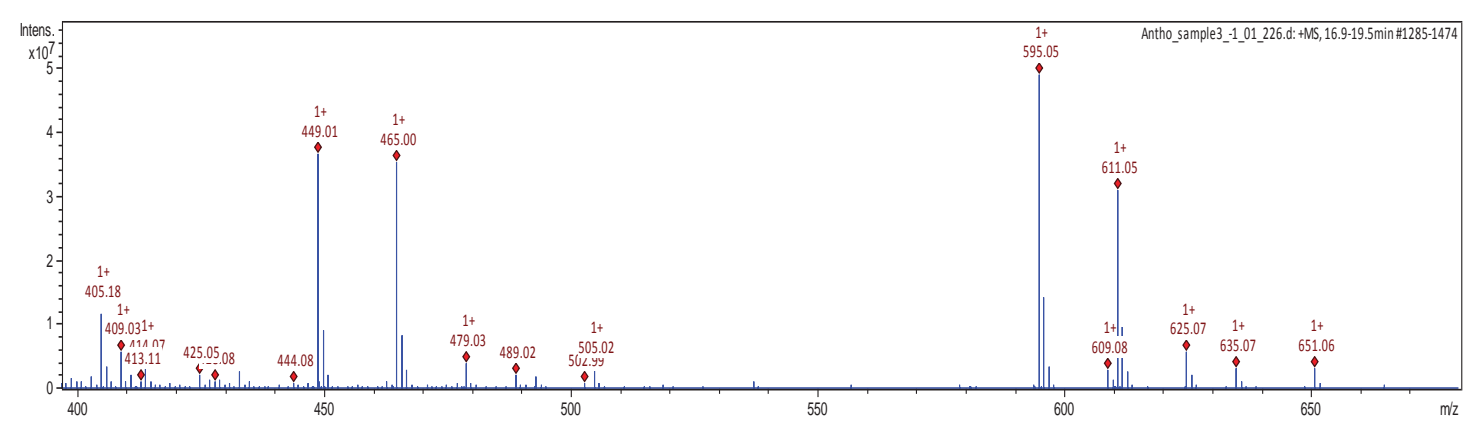

Puc. 2.35. Масс-спектр пиков антоцианидинов из образца 3 


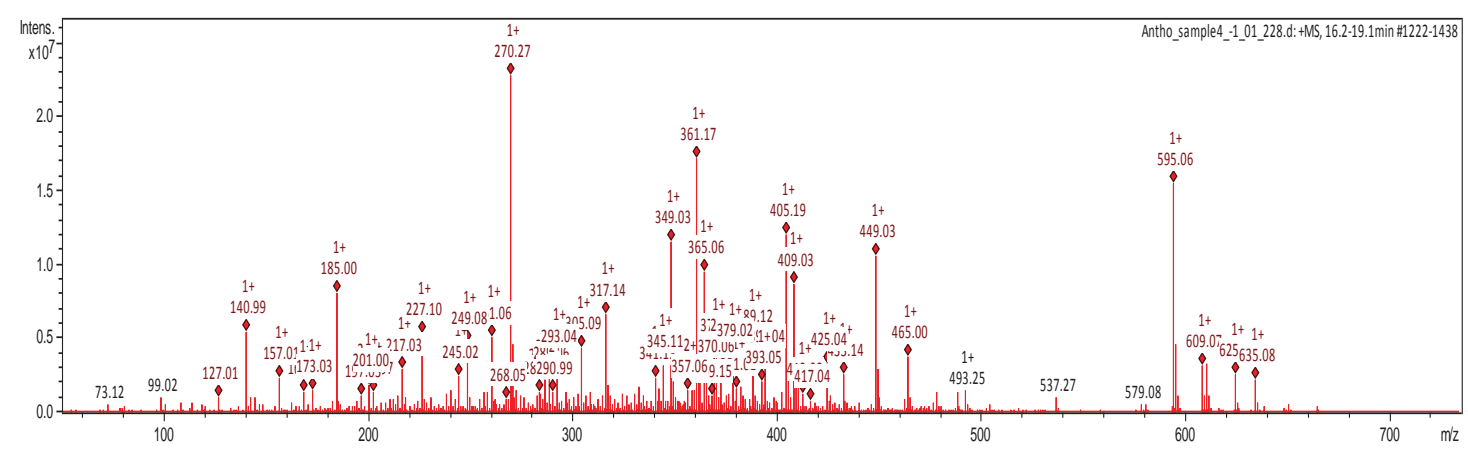

Puc. 2.36. Масс-спектр пиков антоцианидинов из образца 4

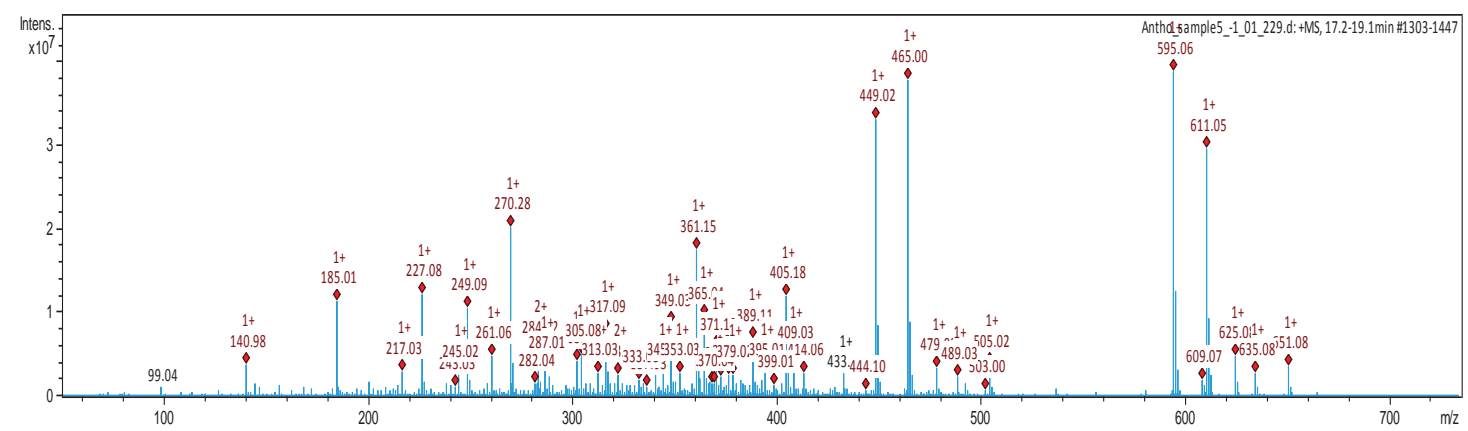

Puc. 2.37. Масс-спектр пиков антоцианидинов из образца 5

Таблища 2.5

\section{Идентификация антоцианидинов в образцах антоцианов,} выделенных различными способами

\begin{tabular}{|c|c|c|c|c|c|c|c|}
\hline \multirow[t]{2}{*}{ Антоцианидин } & \multirow{2}{*}{$\begin{array}{c}\text { Масса моле- } \\
\text { кулярного } \\
\text { иона, m/z }\end{array}$} & \multirow{2}{*}{$\begin{array}{c}\text { Фрагментиро- } \\
\text { ванные ионы, } \\
\text { m/z }\end{array}$} & \multicolumn{5}{|c|}{ Номер образца } \\
\hline & & & 1 & 2 & 3 & 4 & 5 \\
\hline Дельфинидин-3-глюкозид & 465 & 303 & + & + & + & + & + \\
\hline $\begin{array}{l}\text { Дельфинидин-3- } \\
\text { рутинозид }\end{array}$ & 611 & 465,303 & + & + & + & + & + \\
\hline Цианидин-3-глюкозид & 449 & 287 & + & + & + & + & + \\
\hline Цианидин-3-рутинозид & 595 & 449,287 & + & + & + & + & + \\
\hline Петунидин-3-рутинозид & 625 & $479,317,302$ & + & + & + & + & + \\
\hline Пеонидин-3-рутинозид & 609 & 463, 301, 286 & - & + & + & + & + \\
\hline $\begin{array}{l}\text { Пеларгонидин-3-бетта-D- } \\
\text { галактопиранозид }\end{array}$ & 651 & $\begin{array}{c}\text { 633, 505, 342, } \\
331\end{array}$ & - & + & + & - & + \\
\hline $\begin{array}{l}\text { Мальвидин-3-(6-n- } \\
\text { коумароил)-глюкозид }\end{array}$ & 635 & $\begin{array}{c}617,489,331, \\
309\end{array}$ & + & + & + & + & + \\
\hline
\end{tabular}

Примечание: «+» - присутствие антоцианидина в образце, «-» - достаточно низкое содержание данного антоцианидина в образце, либо его полное отсутствие. 
Таким образом, в образцах антоцианов, выделенных различными способами идентифицировано 8 антоцианидинов. Наиболее распространенными были 4 антоцианидина - это цианидин-3-глюкозид, цианидин-3-рутинозид, дельфинидин-3-глюкозид, дельфинидин3-рутинозид. Их идентифицировали во всех образцах антоцианов.

Доля присутствия того или иного антоцианидина в исследуемых образцах зависела от способа выделения антоцианов. Во всех образцах наблюдаются высокие доли выделения таких антоцианидинов как цианидин-3-глюкозида и цианидин-3-рутинозида. Доля петунидин-3рутинозида и мальвидин-3-(6-n-коумароил)-глюкозида остается небольшой при всех способах выделения. Доля присутствия других антоцианидинов определяет способ выделения антоцианов. Так, например, выделение антоцианов, используя ультразвуковую баню, вызывало уменьшение содержания в образцах дельфинидин-3-рутинозида. В данном образце, а также в образце антоцианового пигмента, экстрагированного при температуре $25{ }^{\circ} \mathrm{C}$ в течение 30 мин, наблюдается снижение доли дельфинидин-3-глюкозида.

Кроме того, в образцах 2-5 наблюдалось присутствие пеонидин3-рутинозида. В образце 1 данный цианидин присутствует в очень незначительных количествах. Антоцианидин пеларгонидин-3-бетта-Dгалактопиранозид содержался в образцах 2,3 и 5 . В образцах антоцианов, выделенных с помощью ультразвуковой бани (образец 4) или при температуре $25^{\circ} \mathrm{C}$ в течение 30 мин (образец 1), наблюдается достаточно низкое содержание данного антоцианидина.

Таким образом, идентификация антоцианидинов методом высокоэффективной жидкостной хроматографии и $\mathrm{MC}-\mathrm{MC}$ массспектрометрии показала, что состав антоцианидинов в образцах антоцианов зависит от способа его выделения. Более полному выделению антоцианидинов способствуют экстрагирование антоцианов из ягод черной смородины при температурах $65{ }^{\circ} \mathrm{C}$ и $100{ }^{\circ} \mathrm{C}$ в течение 30 мин и прямая ультразвуковая экстракция в течение 15 мин. При данных условиях выделяются все 8 антоцианидинов. Кроме того, полученные результаты согласуются с данными таблицы 3.4 , где показано, что наиболее полно антоциановый пигмент выделяется при данных условиях экстрагирования. 


\section{Выводы по главе 2}

1. Определена эффективность экстрагирования антоцианов субмолярным раствором соляной кислоты в течение 60 мин, 0,05-0,15 мас. \% растворами каппа-каррагинана, 0,6 \% желатина, 0,1 \% раствором яичного альбумина и БСА в течение 60 мин и 1-10\% растворами аскорбиновой кислоты в течение 30 мин. Экстрагирование антоцианов раствором аскорбиновой кислоты в течение 60 мин приводит к деградации антоцианов.

2. Показано, что оптимальными условиями для извлечения антоцианов являются косвенная ультразвуковая экстракция при температуре $25{ }^{\circ} \mathrm{C}$ в течение 30 мин, прямая ультразвуковая экстракция при температуре $25^{\circ} \mathrm{C}$ в течение 15 мин и экстрагирование пигмента водным раствором при температуре $70{ }^{\circ} \mathrm{C}$ в течение 30 мин. Оптимальной технологией для извлечения антоцианов из выжимок черной смородины является ультразвуковая экстракция при температуре $25^{\circ} \mathrm{C}$ в течение 25 мин.

3. Установлено, что способы экстрагирования антоцианов определяют состав входящих в него антоцианидинов. Более полному выделению антоцианидинов способствуют экстрагирование антоцианов водным раствором и прямая ультразвуковая экстракция в течение 15 мин. При данных условиях выделяются 8 антоцианидинов. 


\section{ГЛава 3. ТЕХНОЛОГИИ ПОЛУЧЕНИЯ \\ И ПОКАЗАТЕЛИ КАЧЕСТВА}

НАТУРАЛЬНЫХ АНТОЦИАНОВЫХ КРАСИТЕЛЕЙ

Красящие добавки - это вещества синтетического или природного происхождения, используемые для придания, восстановления или стандартизации цвета и внешнего вида пищевых продуктов, что делает продукты питания более привлекательными для потребителей $[38,66]$.

Синтетические или искусственные красители обладают значительными технологическими преимуществами по сравнению с большинством натуральных красителей, они дают яркие, легко воспроизводимые цвета, которые невозможно создать с помощью натуральных красителей, а также они менее чувствительны к различным видам воздействия, которым подвергается материал в ходе технологического процесса. Еще одним неоспоримым преимуществом использования синтетических красителей для пищевой промышленности, является простота и дешевизна их производства.

Одними из наиболее важных ограничивающих факторов применения синтетических красителей являются доказательства их потенциального вредного воздействия на здоровье человека в зависимости от используемой дозы [26]. Синтетические красители сами по себе не токсичны, но при использовании в смесях может наблюдаться синергетический эффект [20].

В настоящее время все больший интерес потребители проявляют к пищевой продукции, имеющей в своем составе натуральные ингредиенты, включая красители, которые придают готовым продуктам привлекательный вид, естественный аромат, вкус, дополнительную пищевую ценность, и в целом, воспринимаются как здоровые и безопасные, поскольку многие из них являются нутрицевтиками [21, 76].

Поиск альтернативных натуральных пигментов для замены синтетических красителей является актуальной тенденцией на рынке, особенно в премиальных продуктах питания и в продуктах, предназначенных для детей $[26,53,64,76]$. Красные и желтые красители со- 
ставляют приблизительно около 90 \% от общего количества красителей, добавляемых в пищу [69]. Поэтому существует большой интерес к большей доступности натуральных красных красителей, которые обладают повышенной стабильностью в пищевых матрицах из-за сохраняющихся ограничений их синтетических аналогов [32, 39].

К природным красителям, окрашивающим пищевые продукты в красные цвета, относят: кармин Е120, алканин (алканет) Е103, одним из классов природных пигментов, традиционно используемых пищевой промышленностью для получения красных цветов, являются антоцианы.

Антоцианы и их агликоны (антоцианидины) составляют большую группу природных пигментов, которые одобрены в качестве красителей и пищевых добавок во многих странах. В Европейском союзе им присвоен номер (E163i). Кроме того, антоцианы популярны благодаря своей безопасности и потенциальному применению в медицине, косметике и нутрицевтических продуктах. Представителями этой группы красителей являются собственно антоцианы и энокраситель.

Многие антоциановые красители, такие как экстракты черной смородины (E163iii), кизила, красной смородины, брусники, клюквы, пурпурной моркови или пурпурной кукурузы, содержат в своем составе антоцианы и катехины и могут быть просто помечены в списках ингредиентов как фруктовые или овощные соки и концентраты.

В настоящее время уделяется большое внимание вопросам усовершенствования технологий производства антоциановых красителей из ягодного сырья. В данной главе предложено три технологии получения антоциановых красителей на основе экстрактов антоцианов, выделенных из ягодного сырья Дальневосточного региона (рисунок 3.1). Технологические схемы получения антоциановых экстрактов, полученных путем экстрагирования антоцианов из ягодного сырья водным раствором и ультразвуковой экстракцией приведены на рисунке 3.2 .

Технологические схемы получения экстрактов антоцианов путем экстрагирования водным раствором и ультразвуковой экстракцией из ягодного сырья представлены на рисунке 3.2. 


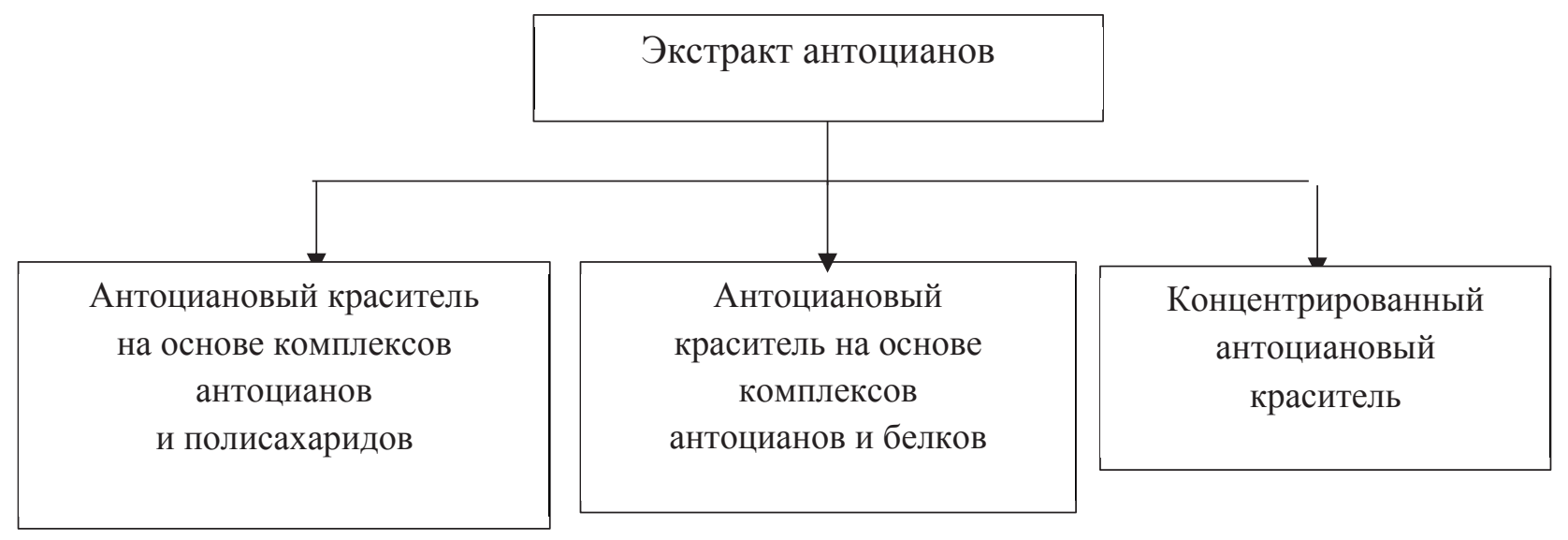

Рис. 3.1. Варианты антоциановых красителей

Органолептические, физико-химические, микробиологические и показатели безопасности экстракта антоцианов, выделенного из ягод черной смородины при температуре $65{ }^{\circ} \mathrm{C}$ в течение 30 мин, представлены в таблице 3.1 .

Экстракт антоцианов, выделенный из ягод черной смородины, представляет собой жидкость темно красного цвета, обладающую ярко выраженным запахом черной смородины и кислым вкусом. Экстракт антоцианов имеет активную кислотность (pH) 3,0, содержит в своем составе 2,99 мг/см ${ }^{3}$ антоцианов и обладает высокой антирадикальной активностью. Микробиологические показатели и показатели безопасности экстракта антоцианов черной смородины не превышают нормативные значения, заложенные в ТР ТС 029/2012 «Требования безопасности пищевых добавок, ароматизаторов и технологических вспомогательных средств» [18].

Экстракт антоцианов черной смородины рекомендуется хранить при температуре $0-5{ }^{\circ} \mathrm{C}$ в течение 3 мес, либо при температуре $-18{ }^{\circ} \mathrm{C}$ в течение 12 мес в невскрытых емкостях.

На основе экстрактов антоцианов был разработан антоциановый краситель, содержащий комплекс антоцианов и полисахаридов. Способ получения красителя включает измельчение свежих или замороженных ягод черной смородины и экстрагирование красящих веществ водными растворами анионных полисахаридов при $65-70{ }^{\circ} \mathrm{C}$ в течение 30 мин при постоянном перемешивании. 
Органолептические, физико-химические, микробиологические и показатели безопасности экстрактов антоцианов, выделенных из ягод черной смородины

\begin{tabular}{|c|c|}
\hline Показатель & Экстракт антоцианов черной смородины \\
\hline \multicolumn{2}{|c|}{ Органолептические показатели } \\
\hline Внешний вид и цвет & Жидкость темно-красного цвета \\
\hline Запах & $\begin{array}{c}\text { Яркий, выраженный запах } \\
\text { черной смородины }\end{array}$ \\
\hline Вкус & Кислый, смородиновый \\
\hline \multicolumn{2}{|c|}{ Физико-химические показатели } \\
\hline Массовая доля сухих веществ, \% & $5,3 \pm 0,5$ \\
\hline 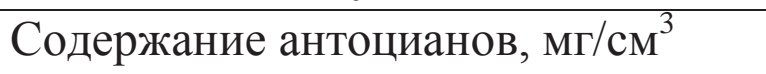 & $2,99 \pm 1,01$ \\
\hline Растворимость в воде & Водорастворимый \\
\hline Кислотность (рН) & 3,0 \\
\hline $\begin{array}{l}\text { Антирадикальная активность, в пе- } \\
\text { рерасчете Trolox эквивалент, мМ }\end{array}$ & $1,30 \pm 0,04$ \\
\hline \multicolumn{2}{|c|}{ Микробиологические показатели ${ }^{1}$} \\
\hline КМАФАнМ КОЕ/Г & Не обнаружено \\
\hline Кишечная палочка в 5 г & Не обнаружено \\
\hline Сальмонеллы в 5 г & Не обнаружено \\
\hline Плесени КОЕ/г, не более & Не обнаружено \\
\hline \multicolumn{2}{|c|}{ Показатели безопасности ${ }^{1}$} \\
\hline Мышьяк, мг/кг & $0,022 \pm 0,003$ \\
\hline Свинец, мг/кг & $0,020 \pm 0,003$ \\
\hline Ртуть мг/кг & Не обнаружено \\
\hline Кадмий, мг/кг & $0,005 \pm 0,001$ \\
\hline
\end{tabular}

${ }^{1}$ Примечание - Согласно ТР ТС 029/2012 - Допустимое содержание КМАФАнМ КОЕ/Г - 100, кишечная палочка, сальмонеллы, плесени - не доп., мышьяк не более 3 мг/кг, свинец не более 10 мг/кг, ртуть не более 1 мг/кг, кадмий не более 1 мг/кг.

Полученный антоциановый краситель, содержащий комплекс антоцианов и анионных полисахаридов, обладает высокими значениями антирадикальной активности (рисунок 3.3). 


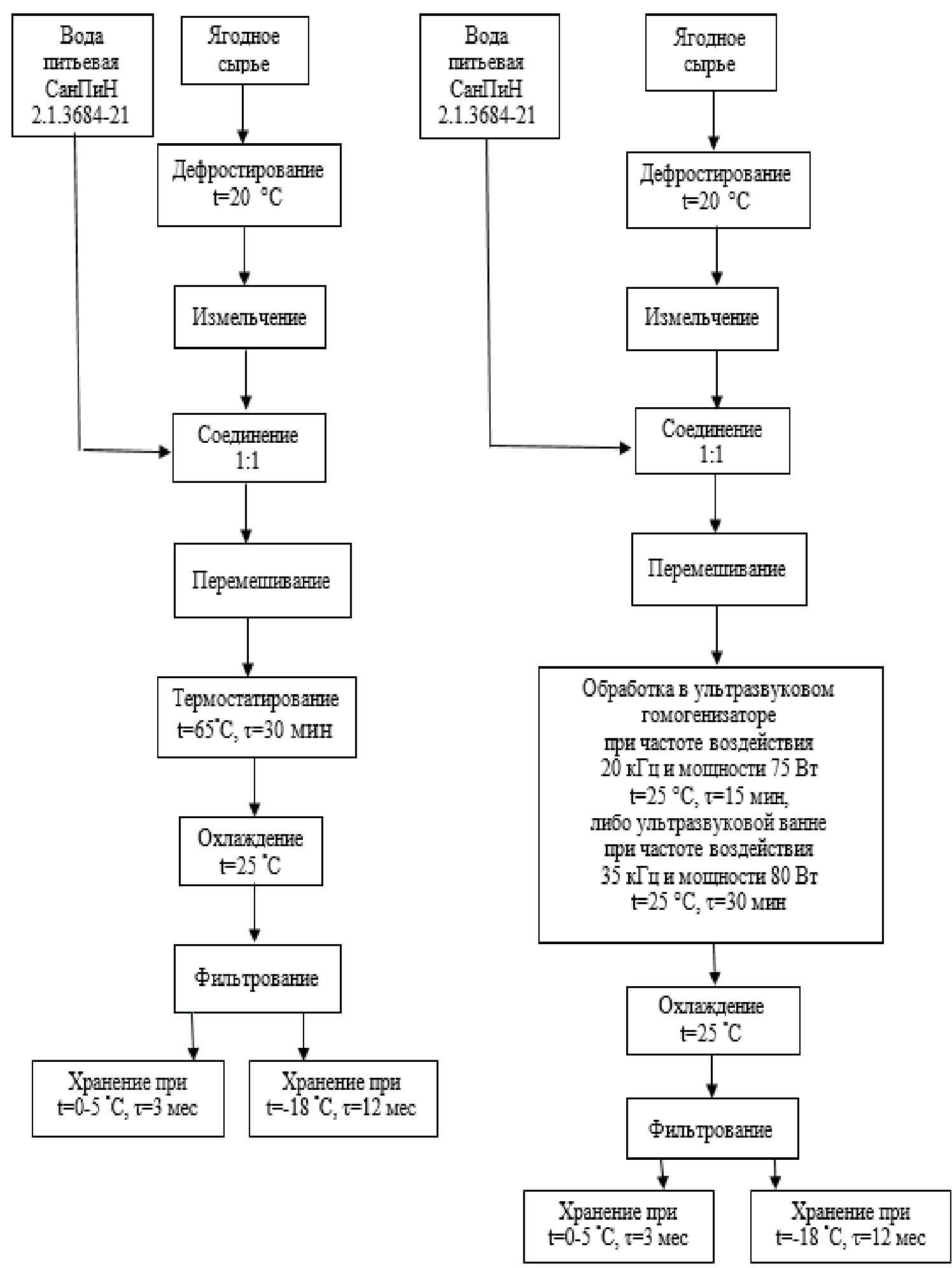

Puc. 3.2. Технологические схемы приготовления экстрактов антоцианов

Введение в раствор антоцианов анионных полисахаридов каппакаррагинана, альгината натрия, агар-агара и пектина увеличивает антирадикальную активность комплексов. Антирадикальная активность этих систем увеличивается в 1,3, 1,3, 1,1 и 1,2 раза, соответственно. 
В объектах выделения полисахариды тесно связаны с полифенолами, обладающими собственной антирадикальной активностью. Такие комплексы очень прочны и при выделении полисахаридов могут сохранять свою структуру.

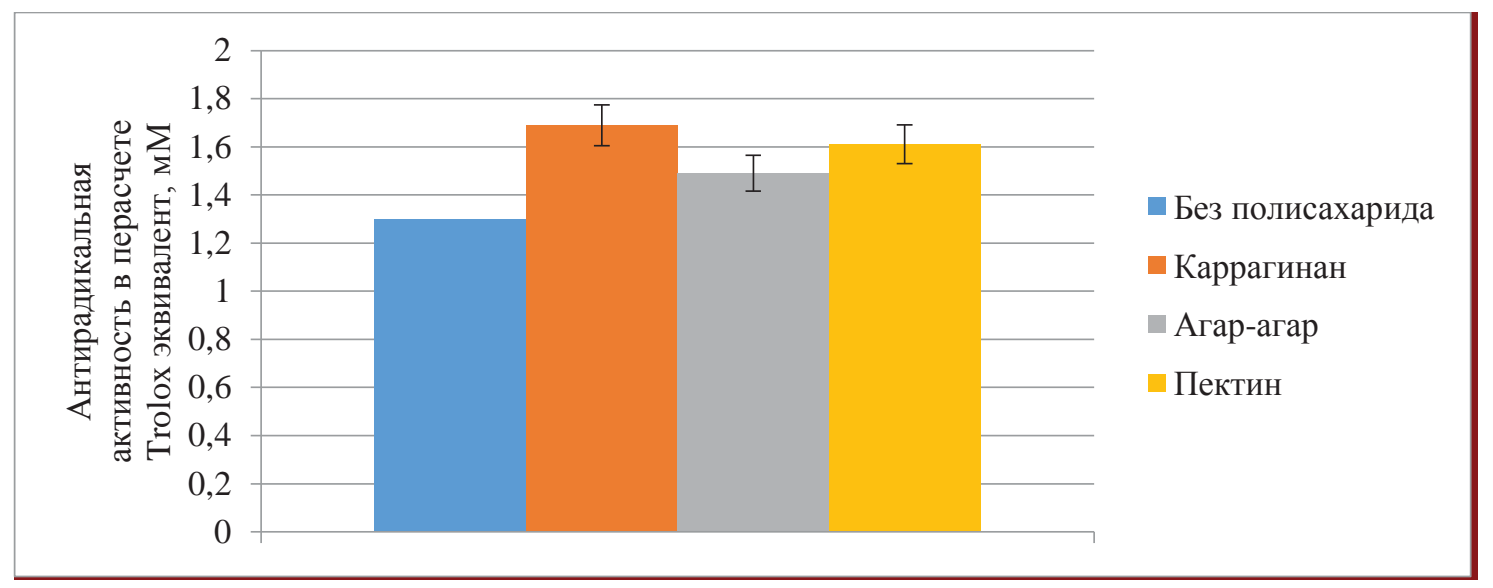

$P u c$. 3.3. Значения антирадикальной активности комплексов, содержащих анионные полисахариды и антоцианы

Поскольку, антоциановый краситель, содержащий комплекс антоцианов и полисахаридов, может быть использован для создания функциональных продуктов питания с целью обогащения их биологически активными соединениями, способными не только повышать пищевую ценность изделия, но и улучшать его органолептические свойства и технологические характеристики, была определена вязкость систем, содержащих анионные полисахариды и антоцианы. Значения динамической вязкости комплексов, содержащих анионные полисахариды и антоцианы при содержании в системе 0,05 мас. \% полисахаридов, представлены на рисунке 3.4. В качестве стандарта использовали водный 0,05 мас. \% раствор полисахарида.

Результаты, представленные на рисунке, показывают, что введение в раствор анионных полисахаридов антоцианов по-разному влияет на его вязкость. Установлено, что введение в растворы агар-агара, каррагинана и пектина антоцианов увеличивает значение динамической вязкости этих комплексов по сравнению с водными растворами полисахаридов. Максимальное увеличение вязкости наблюдается у ком- 
плекса агар-агара и антоцианов, вязкость его увеличивается в 1,5 раза. Вязкость комплексов, содержащих антоцианы и каппа-каррагинан либо пектин, увеличивается в 1,1 и 1,2 раза, соответственно. Образование стойких комплексов между молекулами антоцианов и сульфатными группами агар-агара и каппа-каррагинана способствует увеличению вязкости системы.

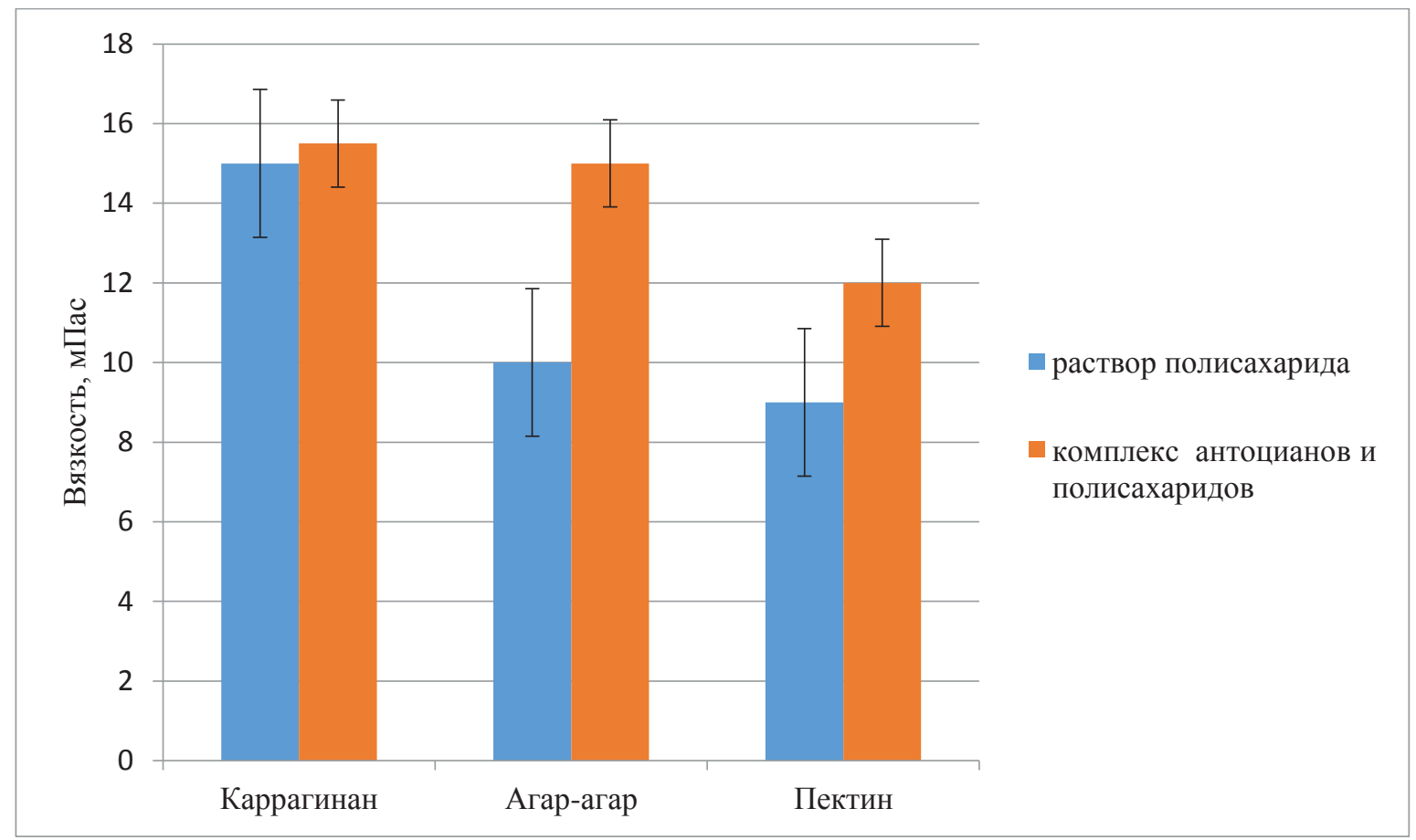

Puc. 3.4. Значения динамической вязкости комплексов анионных полисахаридов и антоцианов, при содержании полисахаридов в растворе 0,05 мас. \%

Увеличение вязкости системы, содержащей пектин и антоцианы, вероятно, связано с химическим составом использованного ягодного сырья. Поскольку, ягоды смородины содержат в своем составе 0,8-2,5 \% пектиновых веществ [13], что может оказывать существенное влияние на увеличение вязкости системы, содержащей пектин и антоцианы.

Органолептические, физико-химические, микробиологические и показатели безопасности антоцианового красителя, содержащего комплекс антоцианов черной смородины и каппа-каррагинана представлены в таблице 3.2 . 


\section{Органолептические, физико-химические, микробиологические и показатели безопасности антоцианового красителя, содержащего комплекс антоцианов черной смородины и каппа-каррагинана}

\begin{tabular}{|c|c|}
\hline Показатель & $\begin{array}{c}\text { Антоциановый краситель, содержащий } \\
\text { комплекс антоцианов и каппа-каррагинан }\end{array}$ \\
\hline \multicolumn{2}{|c|}{ Органолептические показатели } \\
\hline Внешний вид и цвет & Вязкая жидкость темно-красного цвета \\
\hline Запах & $\begin{array}{c}\text { Яркий, выраженный запах черной сморо- } \\
\text { дины }\end{array}$ \\
\hline Вкус & Кислый, смородиновый \\
\hline \multicolumn{2}{|c|}{ Физико-химические показатели } \\
\hline Массовая доля сухих веществ, \% & $12,2 \pm 0,1$ \\
\hline Содержание антоцианов, мг/см ${ }^{3}$ & $4,78 \pm 0,98$ \\
\hline Растворимость в воде & Водорастворимый \\
\hline Кислотность (рН) & 2,7 \\
\hline $\begin{array}{l}\text { Антирадикальная активность, в пе- } \\
\text { рерасчете Trolox эквивалент, мМ }\end{array}$ & $1,69 \pm 0,02$ \\
\hline \multicolumn{2}{|c|}{ Микробиологические показатели ${ }^{I}$} \\
\hline КМАФАнМ КОЕ/Г & Не обнаружено \\
\hline Кишечная палочка в 5 г & Не обнаружено \\
\hline Сальмонеллы в 5 г & Не обнаружено \\
\hline Плесени КОЕ/г, не более & Не обнаружено \\
\hline \multicolumn{2}{|c|}{ Показатели безопасности ${ }^{1}$} \\
\hline Мышьяк, мг/кг & $0,025 \pm 0,001$ \\
\hline Свинец, мг/кг & $0,020 \pm 0,003$ \\
\hline Ртуть мг/кг & Не обнаружено \\
\hline Кадмий, мг/кг & $0,005 \pm 0,001$ \\
\hline
\end{tabular}

${ }^{1}$ Примечание - Согласно ТР ТС 029/2012 - Допустимое содержание КМАФАнМ КОЕ/Г - 100, кишечная палочка, сальмонеллы, плесени - не доп., мышьяк не более 3 мг/кг, свинец не более 10 мг/кг, ртуть не более 1 мг/кг, кадмий не более 1 мг/кг.

Антоциановый краситель, содержащий комплекс антоцианов черной смородины и каппа-каррагинан, представляет собой вязкую 
жидкость темно красного цвета, обладающую ярко выраженным запахом черной смородины и кислым вкусом. Данный комплекс имеет

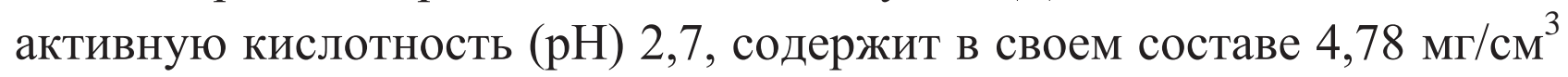
антоцианов и обладает выраженной антирадикальной активностью. Микробиологические показатели и показатели безопасности комплекса, содержащего антоцианы черной смородины и каппакаррагинана, не превышают нормативные значения, заложенные в ТР ТС 029/2012 «Требования безопасности пищевых добавок, ароматизаторов и технологических вспомогательных средств» [18].

Комплекс, содержащий антоцианы черной смородины и каппакаррагинан, рекомендуется хранить при температуре $0-5{ }^{\circ} \mathrm{C}$ в течение 6 мес в невскрытых емкостях.

Технология получения антоцианового красителя, содержащего комплекс антоцианов и белков, включает измельчение свежих или замороженных ягод черной смородины и экстрагирование красящих веществ полимерами белковой природы (желатином, яичным альбумином и БСА) при 65-70 ${ }^{\circ} \mathrm{C}$ в течение 30 мин при постоянном перемешивании.

Процесс образования комплекса сопровождается увеличением количества, выделившихся антоцианов, а процесс создания комплекса улучшает реологические характеристики системы. Значения динамической вязкости комплекса желатин-антоцианы, при 0,2 \% содержании желатина в комплексе, представлены на рисунке 3.5.

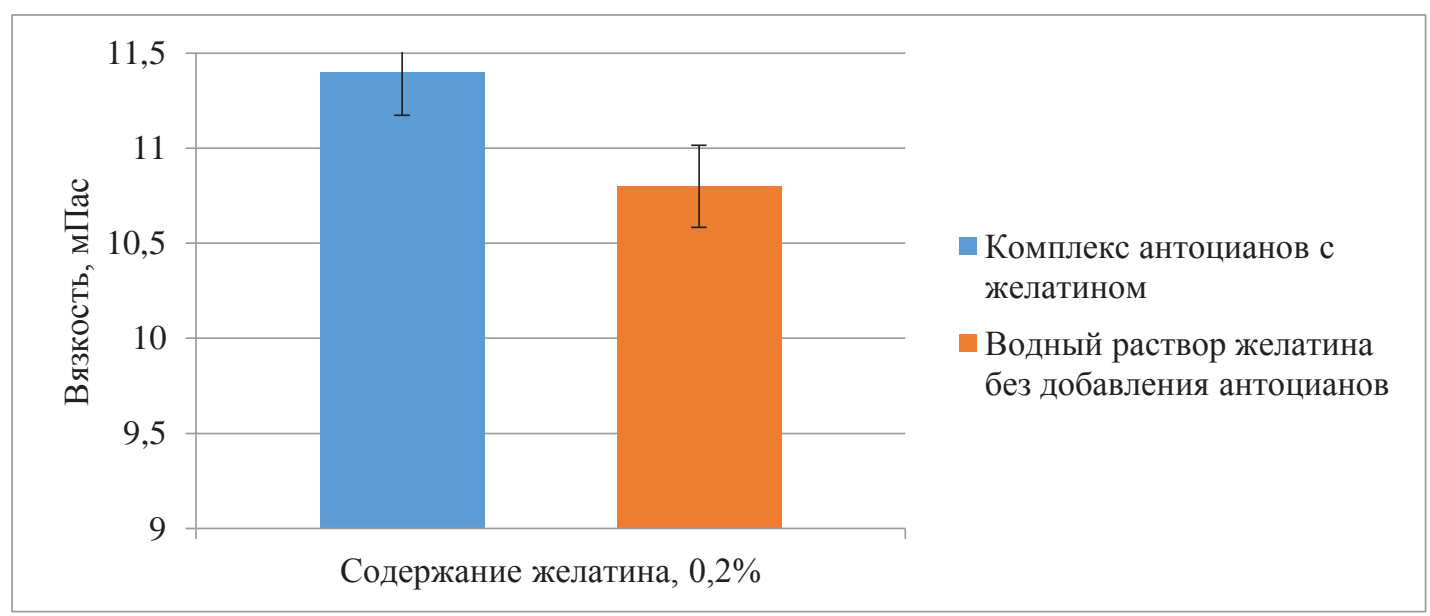

Puc. 3.5. Значения динамической вязкости системы желатин-антоцианы при $0,2 \%$ содержании желатина в комплексе 
Наибольшей вязкостью $(11,4$ мПа·с) обладает комплекс желатин-антоцианы черной смородины, с содержанием в системе желатина $0,2 \%$. Вязкость системы, содержащей $0,2 \%$ желатина и антоцианов жимолости, значительно ниже и составляет 10,2 мПа·с.

Видимо, присутствие в системе антоцианов черной смородины 0,2 \% желатина приводит к образованию дополнительных связей, что, соответственно, способствует ускорению процесса студнеобразования.

Органолептические, физико-химические, микробиологические и показатели безопасности антоцианового красителя, содержащего комплекс антоцианов черной смородины и желатина представлены в таблице 3.3 .

Таблица 3.3

\section{Органолептические, физико-химические и микробиологические} и показатели безопасности антоцианового красителя, содержащего комплекс антоцианов черной смородины и желатина

\begin{tabular}{|c|c|}
\hline Показатель & $\begin{array}{c}\text { Антоциановый краситель, содержащий } \\
\text { комплекс антоцианов и желатина }\end{array}$ \\
\hline \multicolumn{2}{|c|}{ Органолептические показатели } \\
\hline Внешний вид и цвет & Вязкая жидкость темно-красного цвета \\
\hline Запах & $\begin{array}{c}\text { Яркий, выраженный запах черной смо- } \\
\text { родины }\end{array}$ \\
\hline Вкус & Кислый, смородиновый \\
\hline \multicolumn{2}{|c|}{ Физико-химические показатели } \\
\hline Массовая доля сухих веществ, \% & $11,4 \pm 0,5$ \\
\hline 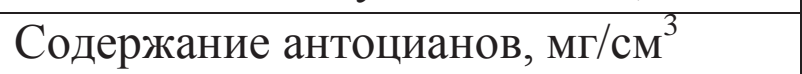 & $4,25 \pm 1,10$ \\
\hline Растворимость в воде & Водорастворимый \\
\hline Кислотность (рН) & 3,0 \\
\hline $\begin{array}{l}\text { Антирадикальная активность, в пе- } \\
\text { рерасчете Trolox эквивалент, мМ }\end{array}$ & $! .2 \pm 0,2$ \\
\hline \multicolumn{2}{|c|}{ Микробиологические показатели ${ }^{1}$} \\
\hline КМАФАнМ КОЕ/Г & Не обнаружено \\
\hline Кишечная палочка в 5 г & Не обнаружено \\
\hline Сальмонеллы в 5 г & Не обнаружено \\
\hline Плесени КОЕ/Г, не более & Не обнаружено \\
\hline
\end{tabular}


Окончание табл. 3.3

\begin{tabular}{|l|c|}
\hline \multicolumn{2}{|c|}{ Показатели безопасности } \\
\hline Мышьяк, мг/кг & $0,020 \pm 0,002$ \\
\hline Свинец, мг/кг & $0,020 \pm 0,004$ \\
\hline Ртуть мг/кг & Не обнаружено \\
\hline Кадмий, мг/кг & $0,005 \pm 0,001$ \\
\hline
\end{tabular}

1 Примечание - Согласно ТР ТС 029/2012 - Допустимое содержание КМАФАнМ КОЕ/Г - 100, кишечная палочка, сальмонеллы, плесени - не доп., мышьяк не более 3 мг/кг, свинец не более 10 мг/кг, ртуть не более 1 мг/кг, кадмий не более 1 мг/кг.

Антоциановый краситель, содержащий комплекс антоцианов черной смородины и желатина, представляет собой вязкую жидкость темно красного цвета, обладающую ярко выраженным запахом черной смородины и кислым вкусом. Данный комплекс имеет активную кислотность $(\mathrm{pH}) 3,0$, содержит в своем составе

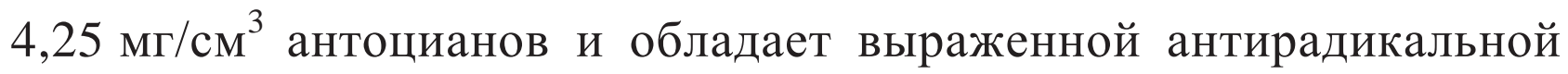
активностью. Микробиологические показатели и показатели безопасности комплекса, содержащего антоцианы черной смородины и каппа-каррагинана, не превышают нормативные значения, заложенные в ТР ТС 029/2012 «Требования безопасности пищевых добавок, ароматизаторов и технологических вспомогательных средств» [18].

Комплекс, содержащий антоцианы черной смородины и желатина, рекомендуется хранить при температуре $0-5{ }^{\circ} \mathrm{C}$ в течение 3 мес в невскрытых емкостях.

Комплексы, содержащие антоцианы и биополимеры, способные изменять окраску при изменении $\mathrm{pH}$ системы, а также их УФспектральные исследования показывающие, что максимум их поглощения находится при длине волны 515 нм (рисунки 2.8 и 2.11), согласно ГОСТ 33767-2016 «Добавки пищевые. Методы идентификации и определения массовой доли основного красящего вещества в пищевом красителе антоцианы E163» [5], можно идентифицировать как пищевой краситель - антоцианы E163. 
Технологическая схема получения концентрированного антоцианового красителя представлена на рисунке 3.6.

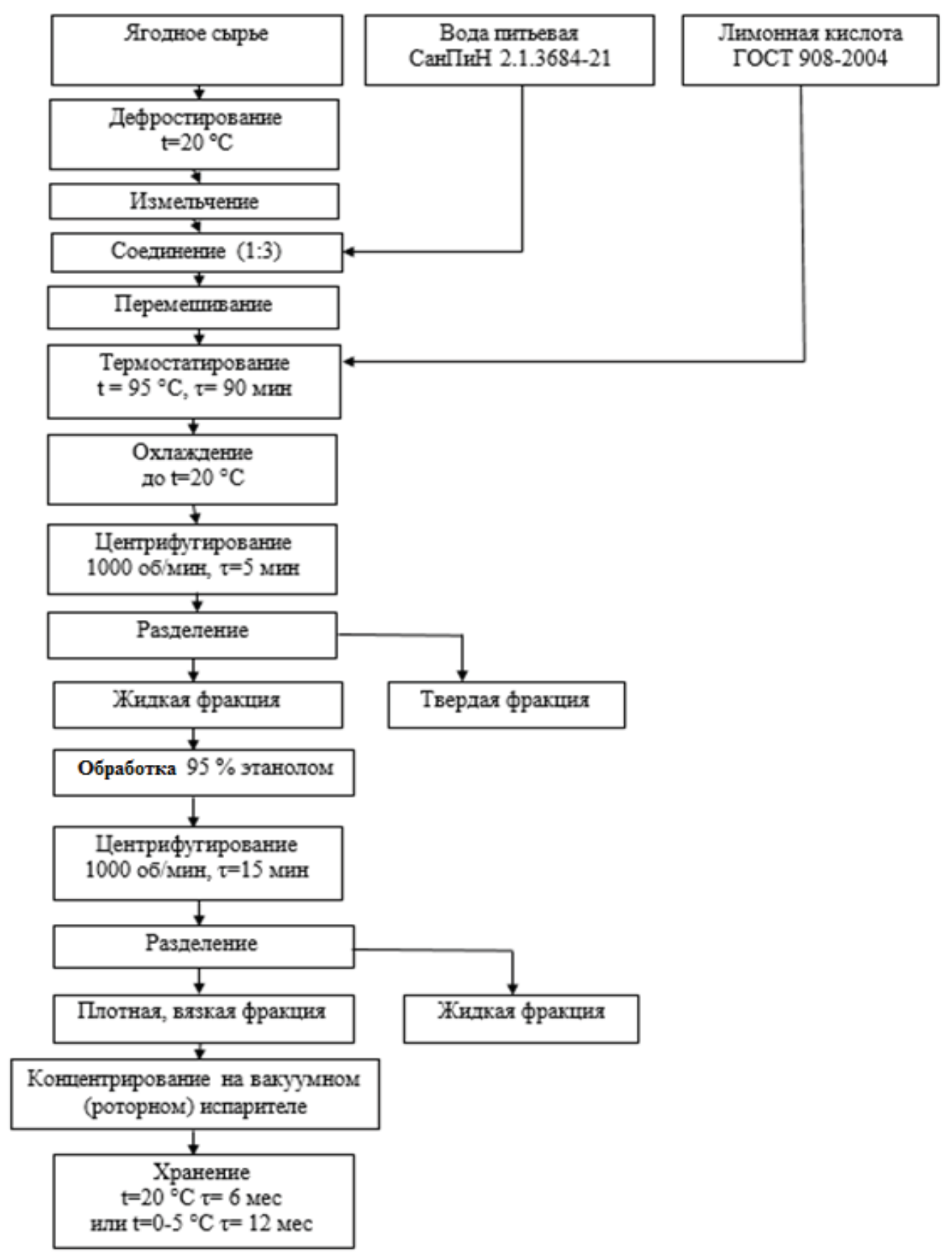

Рuc. 3.6. Технологическая схема получения концентрированного антоцианового красителя

Технология получения концентрированного антоцианового красителя включает измельчение ягодного сырья, гидролиз протопекти- 
на лимонной кислотой, последующую обработку водного раствора этанолом, отделение и концентрирование более плотной вязкой фракции.

УФ-спектр концентрированного антоцианового красителя представлен на рисунке 3.7.

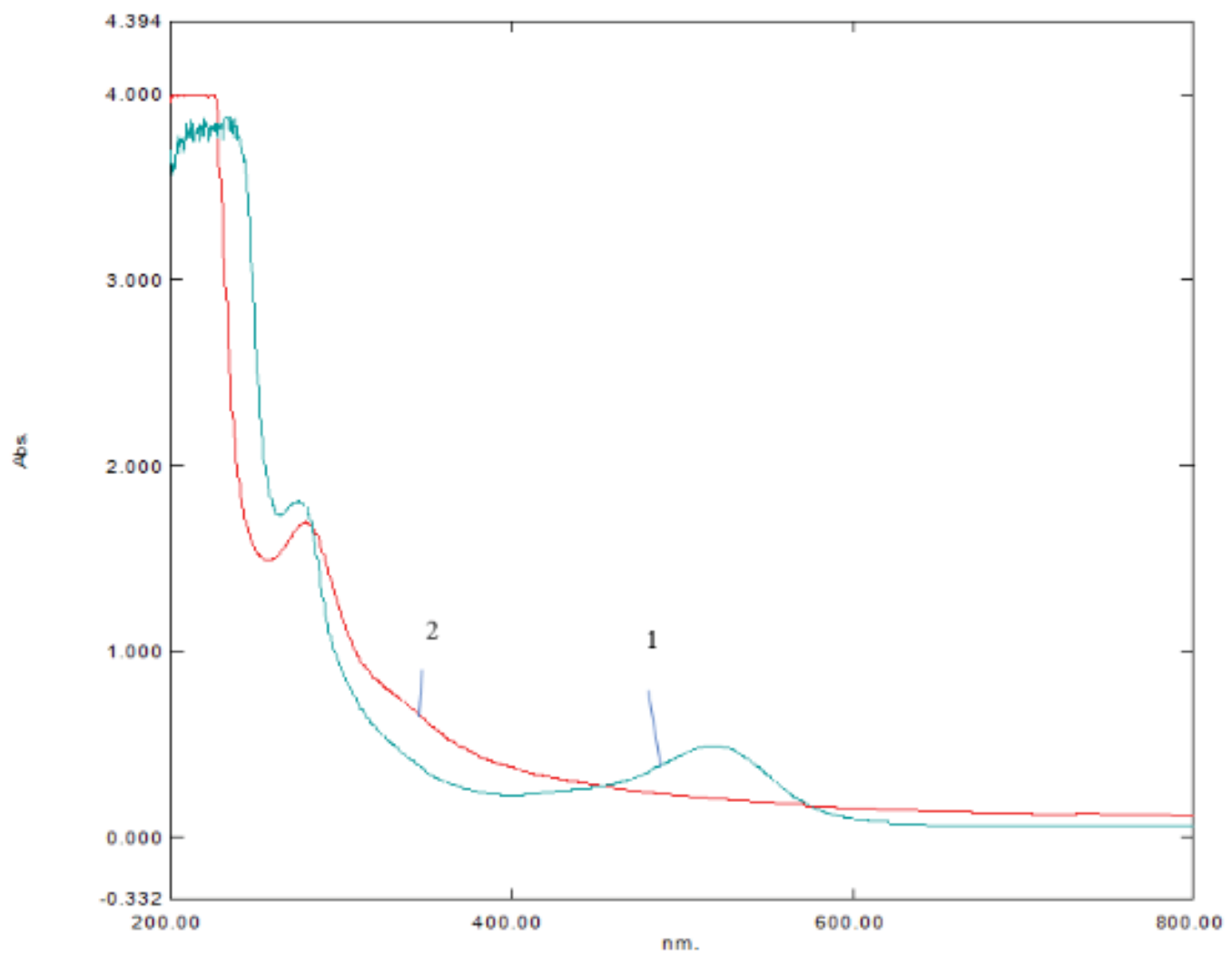

Puc. 3.7. УФ-спектры концентрированного антоцианового красителя и (1) и 1,5 \% водного раствора яблочного пектина (2)

Результаты рисунка 3.7 показывают, что в состав концентрированного антоцианового красителя входят антоцианы (пик при длине волны 515 нм) и пектиновые вещества (пик при длине волны 280 нм).

Показатели качества антоцианового красителя из черной смородины, полученного методом концентрирования представлены в таблице 3.4. Из нее видно, что полученный методом концентрирования краситель имеет темно-красный цвет и ярко выраженный запах черной смородины. Концентрированный антоциановый краситель имеет густую сиропообразную консистенцию, содержит в своем составе 7,83 мг/см ${ }^{3}$ антоцианов, обладает полной растворимостью и обладает выраженной антирадикальной активностью - 1,76 мM Trolox эквивалент. 


\section{Органолептические, физико-химические, микробиологические и показатели безопасности концентрированного антоцианового красителя из черной смородины}

\begin{tabular}{|c|c|}
\hline Показатель & $\begin{array}{c}\text { Концентрированный антоциановый } \\
\text { краситель }\end{array}$ \\
\hline \multicolumn{2}{|c|}{ Органолептические показатели } \\
\hline Внешний вид и цвет & $\begin{array}{l}\text { Густая сиропообразная жидкость, } \\
\text { темно-красного цвета }\end{array}$ \\
\hline Запах & $\begin{array}{l}\text { Яркий, выраженный запах черной } \\
\text { смородины }\end{array}$ \\
\hline Вкус & Кислый, смородиновый \\
\hline \multicolumn{2}{|c|}{ Физико-химические показатели } \\
\hline Массовая доля сухих веществ, \% & $18,20 \pm 0,85$ \\
\hline 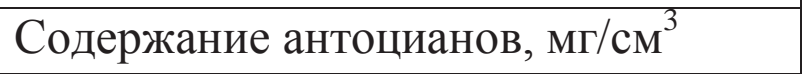 & $7,83 \pm 1,01$ \\
\hline Растворимость в воде & Полная \\
\hline Кислотность (рН) & 1,8 \\
\hline $\begin{array}{l}\text { Антирадикальная активность, в пе- } \\
\text { рерасчете Trolox эквивалент, мМ }\end{array}$ & $1,76 \pm 0,20$ \\
\hline \multicolumn{2}{|c|}{ Микробиологические показатели ${ }^{T}$} \\
\hline КМАФАнМ КОЕ/Г & Не обнаружено \\
\hline Кишечная палочка в 5 г & Не обнаружено \\
\hline Сальмонеллы в 5 г & Не обнаружено \\
\hline Плесени КОЕ/г, не более & Не обнаружено \\
\hline \multicolumn{2}{|c|}{ Показатели безопасности ${ }^{1}$} \\
\hline Мышьяк, мг/кг & $0,030 \pm 0,004$ \\
\hline Свинец, мг/кг & $0,015 \pm 0,001$ \\
\hline Ртуть мг/кг & Не обнаружено \\
\hline Кадмий, мг/кг & $0,005 \pm 0,001$ \\
\hline
\end{tabular}

${ }^{1}$ Примечание - Согласно ТР ТС 029/2012 - Допустимое содержание КМАФАнМ КОЕ/Г - 100, кишечная палочка, сальмонеллы, плесени - не доп., мышьяк не более 3 мг/кг, свинец не более 10 мг/кг, ртуть не более 1 мг/кг, кадмий не более 1 мг/кг.

Микробиологические показатели и показатели безопасности концентрированного красителя, содержащего антоцианы и пектино- 
вые вещества, не превышают нормативные значения, заложенные в ТР ТС 029/2012 «Требования безопасности пищевых добавок, ароматизаторов и технологических вспомогательных средств» [18].

Концентрированный антоциановый краситель рекомендуется хранить при температуре $20^{\circ} \mathrm{C}$ в течение 6 мес либо 0-5 ${ }^{\circ} \mathrm{C}$ в течение 12 мес в невскрытых емкостях.

\section{Выводы по главе 3}

1. На основе комплексов антоцианов и биополимеров - полисахаридов и белков, разработаны два экологически безопасных натуральных антоциановых красителя, которые могут быть использованы для создания функциональных продуктов, обогащенных биологически активными веществами, с улучшенными органолептическими и технологическими свойствами.

2. Показано, что разработанный концентрированный антоциановый краситель безопасен для потребителя, имеет густую сиропообразную консистенцию, содержит в своем составе пектиновые веще-

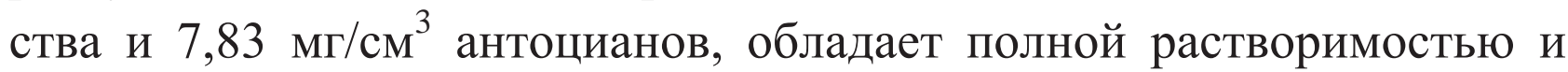
выраженной антирадикальной активностью - 1,76 мM Trolox эквивалент. 


\section{ГЛава 4. ИСПОЛЬЗОВАНИЕ АНТОЦИАНОВОГО КРАСИТЕЛЯ В ПИЩЕВЫХ ТЕХНОЛОГИЯХ И БИОТЕХНОЛОГИЯХ}

В настоящее время существует два направления пищевого использования антоцианового красителя. Во-первых, антоциановый краситель широко применяется для окраски и придания вкусовых качеств пищевым продуктам. Второе и интенсивно развивающееся в настоящее время направление использования антоцианов, выделенных из различных растительных источников, это включение их в биополимерные пленки для создания смарт упаковки.

\section{1. Использование антоцианового красителя в технологии кондитерских изделий}

Кондитерское производство в настоящее время обладает довольно высоким потенциалом для развития в области создания специализированных функциональных продуктов питания, что может способствовать организации сбалансированных рационов на уровне физиологически рекомендуемых норм потребления функциональных ингредиентов, благоприятных для сохранения здоровья населения.

$\mathrm{C}$ целью расширения ассортимента и улучшения качества данной группы продуктов, придания изделиям красивого внешнего вида и аромата, а также обогащения их биологически активными веществами, в них в качестве функциональных ингредиентов можно вводить антоциановые красители. В данной работе предлагаются технологии производства четырех групп кондитерских изделий с добавлением антоциановых красителей - это сахаристые кондитерские изделия, пастильные изделия, отделочные полуфабрикаты и мучные кондитерские изделия.

\subsection{1. Использования антоцианового красителя в производстве функциональных сахаристых кондитерских изделий}

В данной работе в качестве сахаристого изделия был выбран мармелад. В производстве мармелада использовался антоциановый краситель на основе комплексов полисахаридов и экстрактов антоци- 
анов, выделенных из дикорастущего ягодного сырья Дальневосточного региона - лимонника китайского (Schisándra chinénsis) и калины обыкновенной (Vibúrnum ópulus).

Мармелад готовили по стандартной технологии [15], в рецептуре которого, краситель и студнеобразователь были заменены антоциановым красителем, содержащим комплекс антоцианов и полисахарида. В качестве структурообразователя в рецептуре мармелада был использован агар-агар. Технология приготовления комплекса включала предварительное замачивание агар-агара в количестве 3 \% в водном растворе антоцианов при температуре $10-15{ }^{\circ} \mathrm{C}$ в течение 30 минут. Затем в раствор добавляли сахар, патоку и нагревали до полного растворения компонентов. С целью выбора оптимального количества комплекса антоцианов и структурообразователя, было приготовлено 6 образцов желейного мармелада, в которых изменялось содержание комплекса $(24,26$ и 28 \%). Технологическая схема мармелада представлена на рисунке 4.1.

Органолептическая оценка образцов желейного мармелада с различным содержанием комплексов антоцианов ягод лимонника и калины и полисахарида агар-агара представлена в таблице 4.1. Содержание антоцианового пигмента в 100 г исследуемых образцов мармелада приведено в таблице 4.2.

Из результатов, представленных в таблице 4.1 видно, что наилучшие органолептические показатели имели образцы мармелада 2 и 5 с добавлением 26 \% комплекса, содержащего агар-агар и экстракты антоцианов ягод лимонника и калины. Мармелад с добавлением комплекса приобретал приятный ярко-красный цвет. Кроме того, мармелад с экстрактом антоцианов лимонника имел приятный кисло-сладкий вкус, с антоцианами калины к кисло-сладкому вкусу добавлялась легкая горечь. Содержание антоцианов (таблица 4.2) в образце мармелада с добавлением 26 \% комплекса агар-агара и антоцианов лимонника составляет 80,16 мг, в образце с добавлением антоцианов калины составляет 51,12 мг в 100 г продукта. 


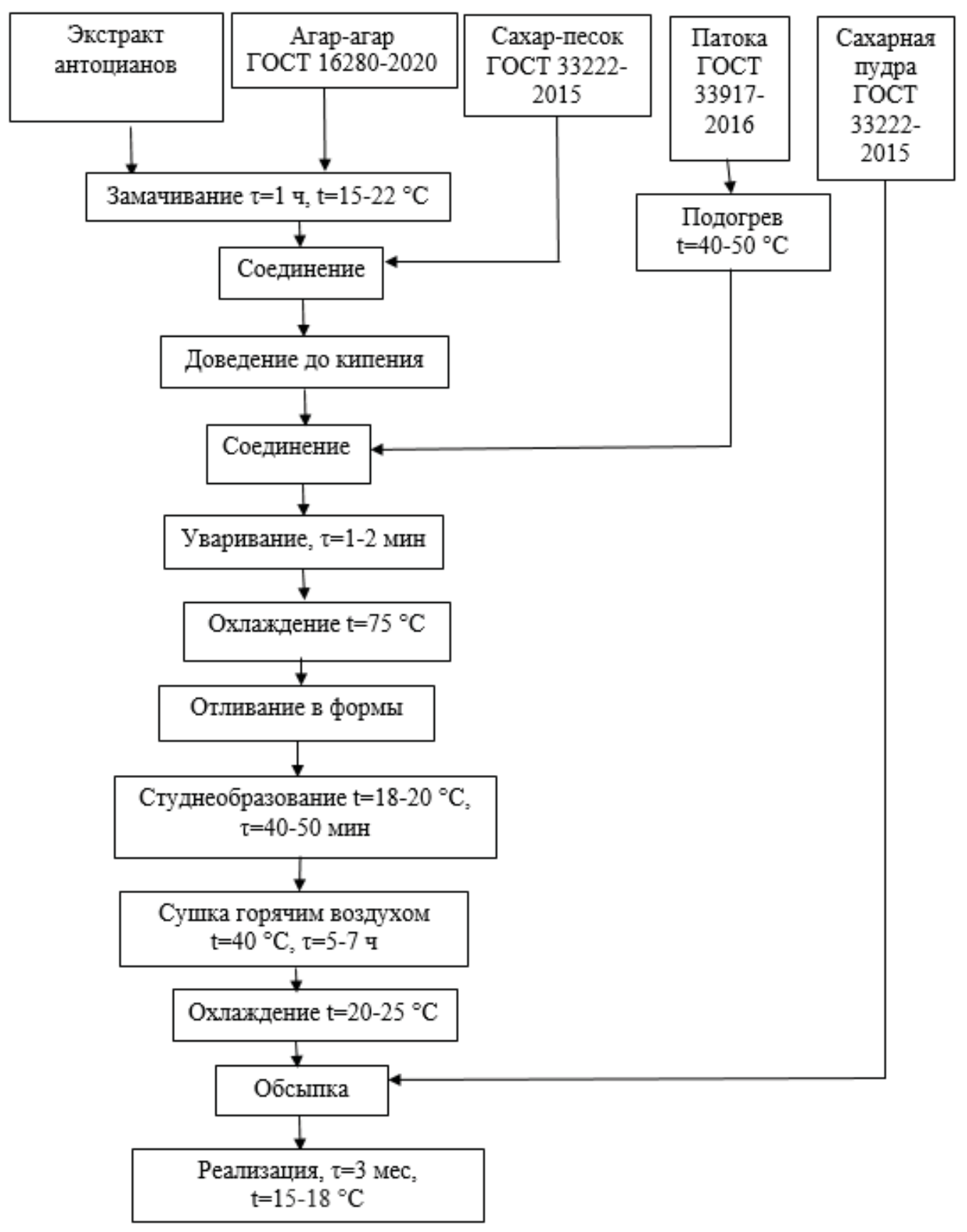

Puc. 4.1. Технологическая схема мармелада

с добавлением комплекса антоцианов и агар-агара 
Таблица 4.1

\section{Органолептическая оценка желейного мармелада с добавлением}

экстракта антоцианов, выделенных из ягод лимонника и калины

\begin{tabular}{|c|c|c|c|c|c|c|c|}
\hline \multirow{4}{*}{$\begin{array}{l}\text { По- } \\
\text { ка- } \\
\text { за- } \\
\text { тель }\end{array}$} & \multirow{4}{*}{$\begin{array}{c}\text { Кон- } \\
\text { троль- } \\
\text { ный } \\
\text { образец } \\
\text { (без экс- } \\
\text { тракта) }\end{array}$} & \multicolumn{6}{|c|}{$\begin{array}{l}\text { Образцы мармелада с добавлением } \\
\text { комплексов антоцианов и агар-агара }\end{array}$} \\
\hline & & \multicolumn{3}{|c|}{ лимонник } & \multicolumn{3}{|c|}{ калина } \\
\hline & & 1 & 2 & 3 & 4 & 5 & 6 \\
\hline & & $24 \%$ & $26 \%$ & $28 \%$ & $24 \%$ & $26 \%$ & $28 \%$ \\
\hline Цвет & $\begin{array}{l}\text { светло- } \\
\text { кремо- } \\
\text { вый }\end{array}$ & $\begin{array}{l}\text { светло- } \\
\text { красный }\end{array}$ & $\begin{array}{l}\text { ярко- } \\
\text { красный }\end{array}$ & $\begin{array}{l}\text { ярко- } \\
\text { красный }\end{array}$ & $\begin{array}{l}\text { светло- } \\
\text { красный }\end{array}$ & $\begin{array}{l}\text { ярко- } \\
\text { красный }\end{array}$ & $\begin{array}{l}\text { ярко- } \\
\text { крас- } \\
\text { ный }\end{array}$ \\
\hline Вкус & $\begin{array}{l}\text { умерен- } \\
\text { но-слад- } \\
\text { кий }\end{array}$ & $\begin{array}{l}\text { харак- } \\
\text { терный } \\
\text { кисло- } \\
\text { сладкий }\end{array}$ & $\begin{array}{l}\text { харак- } \\
\text { терный } \\
\text { кисло- } \\
\text { сладкий }\end{array}$ & \begin{tabular}{|l} 
харак- \\
терный \\
кисло- \\
сладкий
\end{tabular} & $\begin{array}{l}\text { харак- } \\
\text { терный } \\
\text { кисло- } \\
\text { сладкий }\end{array}$ & $\begin{array}{l}\text { харак } \\
\text { терный } \\
\text { кисло- } \\
\text { сладкий } \\
\text { с легкой } \\
\text { горечью }\end{array}$ & $\begin{array}{l}\text { харак } \\
\text { терный } \\
\text { кисло- } \\
\text { слад- } \\
\text { кий с } \\
\text { легкой } \\
\text { горе- } \\
\text { чью }\end{array}$ \\
\hline $\begin{array}{l}\text { 3a- } \\
\text { пах }\end{array}$ & $\begin{array}{l}\text { синтети- } \\
\text { ческий }\end{array}$ & $\begin{array}{l}\text { слабо } \\
\text { выра- } \\
\text { женный } \\
\text { запах } \\
\text { лимон- } \\
\text { ника }\end{array}$ & $\begin{array}{l}\text { прият- } \\
\text { ный } \\
\text { запах } \\
\text { лимон- } \\
\text { ника }\end{array}$ & $\begin{array}{l}\text { прият- } \\
\text { ный } \\
\text { запах } \\
\text { лимон- } \\
\text { ника }\end{array}$ & $\begin{array}{l}\text { слабо } \\
\text { выра- } \\
\text { женный } \\
\text { запах } \\
\text { калины }\end{array}$ & $\begin{array}{l}\text { прият- } \\
\text { ный } \\
\text { запах } \\
\text { лимон- } \\
\text { ника }\end{array}$ & $\begin{array}{l}\text { прият- } \\
\text { ный } \\
\text { запах } \\
\text { лимон- } \\
\text { ника }\end{array}$ \\
\hline $\begin{array}{l}\text { Кон- } \\
\text { си- } \\
\text { стен- } \\
\text { ция }\end{array}$ & $\begin{array}{c}\text { студне- } \\
\text { образ- } \\
\text { разная }\end{array}$ & $\begin{array}{l}\text { плотная } \\
\text { резино- } \\
\text { подоб- } \\
\text { ная }\end{array}$ & $\begin{array}{l}\text { студне- } \\
\text { образ- } \\
\text { ная }\end{array}$ & $\begin{array}{l}\text { плотная } \\
\text { резино- } \\
\text { подоб- } \\
\text { ная }\end{array}$ & $\begin{array}{l}\text { плотная } \\
\text { резино- } \\
\text { подоб- } \\
\text { ная }\end{array}$ & $\begin{array}{l}\text { студне- } \\
\text { образ- } \\
\text { ная }\end{array}$ & плотная \\
\hline
\end{tabular}

Таблица 4.2

Содержание антоцианов в 100 г мармелада

\begin{tabular}{|l|l|}
\hline \multicolumn{2}{|c|}{ Содержание антоцианов в 100 г мармелада, мг } \\
\hline лимонник & калина \\
\hline $26 \%$ комплекс & $26 \%$ комплекс \\
\hline $80,16 \pm 2,55$ & $51,12 \pm 4,05$ \\
\hline
\end{tabular}


Расчетным методом определялось можно ли мармелад с добавлением антоцианов лимонника и калины рассматривать как функциональный продукт питания (ФПП). Рекомендуемая норма потребления антоцианов для взрослого населения составляет 50 мг в сутки [12]. Содержание антоцианов в 30 г мармелада представлено в таблице 4.3.

Таблица 4.3

\section{Степень удовлетворения суточной потребности} организма в антоцианах

\begin{tabular}{|l|c|}
\hline \multicolumn{1}{|c|}{ Продукт } & $\begin{array}{c}\text { Содержание антоцианов в 30 г мар- } \\
\text { мелада, \% от суточной нормы по- } \\
\text { требления }\end{array}$ \\
\hline $\begin{array}{l}\text { Мармелад с добавлением 26 \% комплек- } \\
\text { са антоцианов лимонника и агар-агара }\end{array}$ & 48 \\
\hline $\begin{array}{l}\text { Мармелад с добавлением 26 \% комплек- } \\
\text { са антоцианов ягод калины и агар-агара }\end{array}$ & 31 \\
\hline
\end{tabular}

Следовательно, мармелад с добавлением комплекса, содержащего агар-агар и антоцианы ягод лимонника и калины, можно считать ФПП, поскольку содержание в нем антоцианов составляет более $15 \%$ [6] от суточной нормы потребления.

Значения предела прочности мармелада с добавлением комплекса антоцианов и агар-агара представлены на рисунке 4.2. В качестве стандарта использовали мармелад, приготовленный без добавления комплекса по стандартной технологии, приведенной в сборнике рецептур [15].

Предел прочности мармелада с добавлением комплексов выше, чем у мармелада без его добавления. Наиболее прочной структурой обладает мармелад с добавлением комплексов, содержащих антоцианы лимонника, его предел прочности составляет 14912,9 Па. Предел прочности мармелада с добавлением комплекса, содержащего антоцианы калины, ниже и составляет 13981,1 Па. Видимо, образование стойких оксониевых комплексов за счет содержащегося в гетероциклическом кольце антоцианов кислорода, способного электростатически взаимодействовать с отрицательно заряженными функциональными группами полисахаридов, оказывает существенное влияние на 
упрочнение структуры мармелада. Кроме того, присутствующие в молекулах полисахаридов сульфатные группы, обладая высокой реакционной способностью [36], прочно удерживают в образовавшейся трехмерной сетке жидкую фазу - раствор антоцианов, что улучшает структурно механические свойства студня.

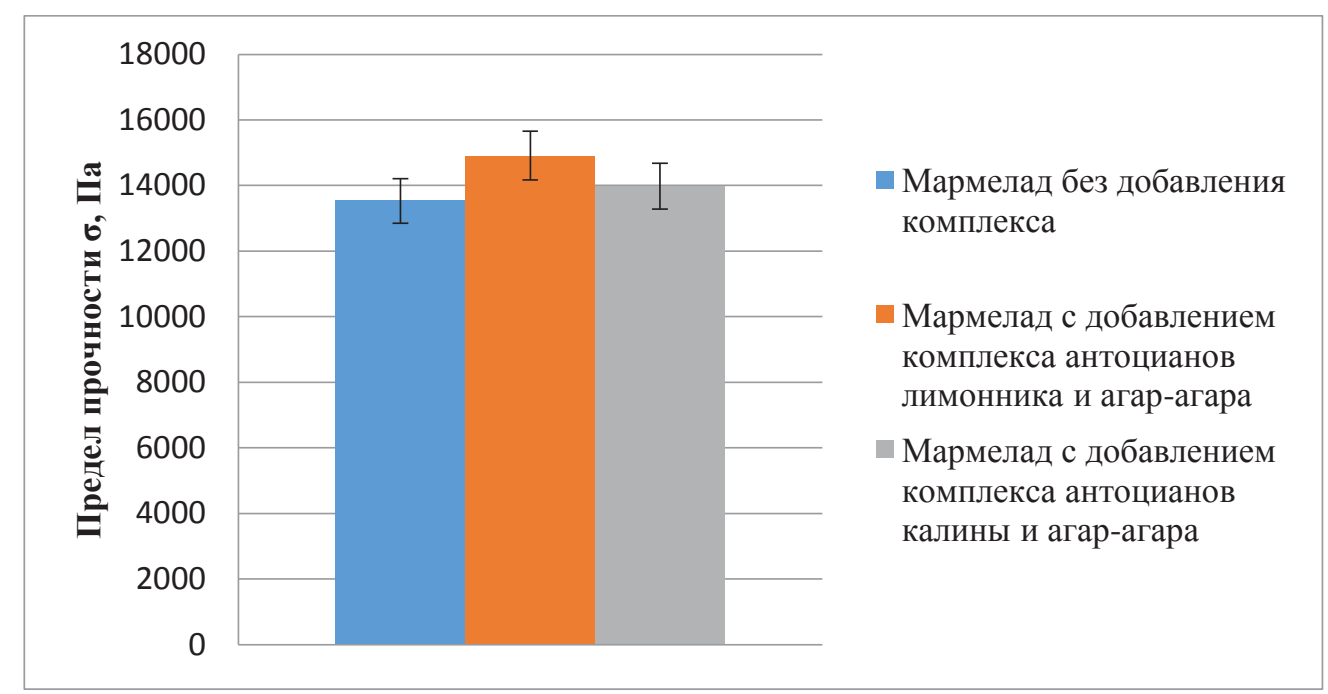

Рuc. 4.2. Значения предела прочности мармелада с добавлением $26 \%$ комплекса антоцианов и агар-агара

Таким образом, использование 26 \% комплекса, содержащего агар-агар и экстракт антоцианов лимонника и калины, при производстве мармелада позволяет получать функциональный продукт с высокими органолептическими показателями и улучшенными структурно механическими свойствами.

\subsection{2. Использования антоцианового красителя в производстве функциональных пастильных кондитерских изделий}

В данной работе показана возможность использования антоциановых красителей, содержащих комплексы антоцианов черной смородины с желатином, в производстве зефира.

Зефир готовили по стандартной рецептуре [15]. Растворы антоцианов черной смородины добавляли в виде жидкого комплекса антоцианов и желатина к зефирной массе в количестве 11, 13 и 15 \%. Технологическая схема производства зефира с добавлением комплекса антоцианов и желатина представлена на рисунке 4.3. 
В зависимости от количества используемого комплекса, зефир имел различную интенсивность окраски розового цвета. Влияние содержания комплекса на органолептические показатели зефира представлено в таблице 4.4 .

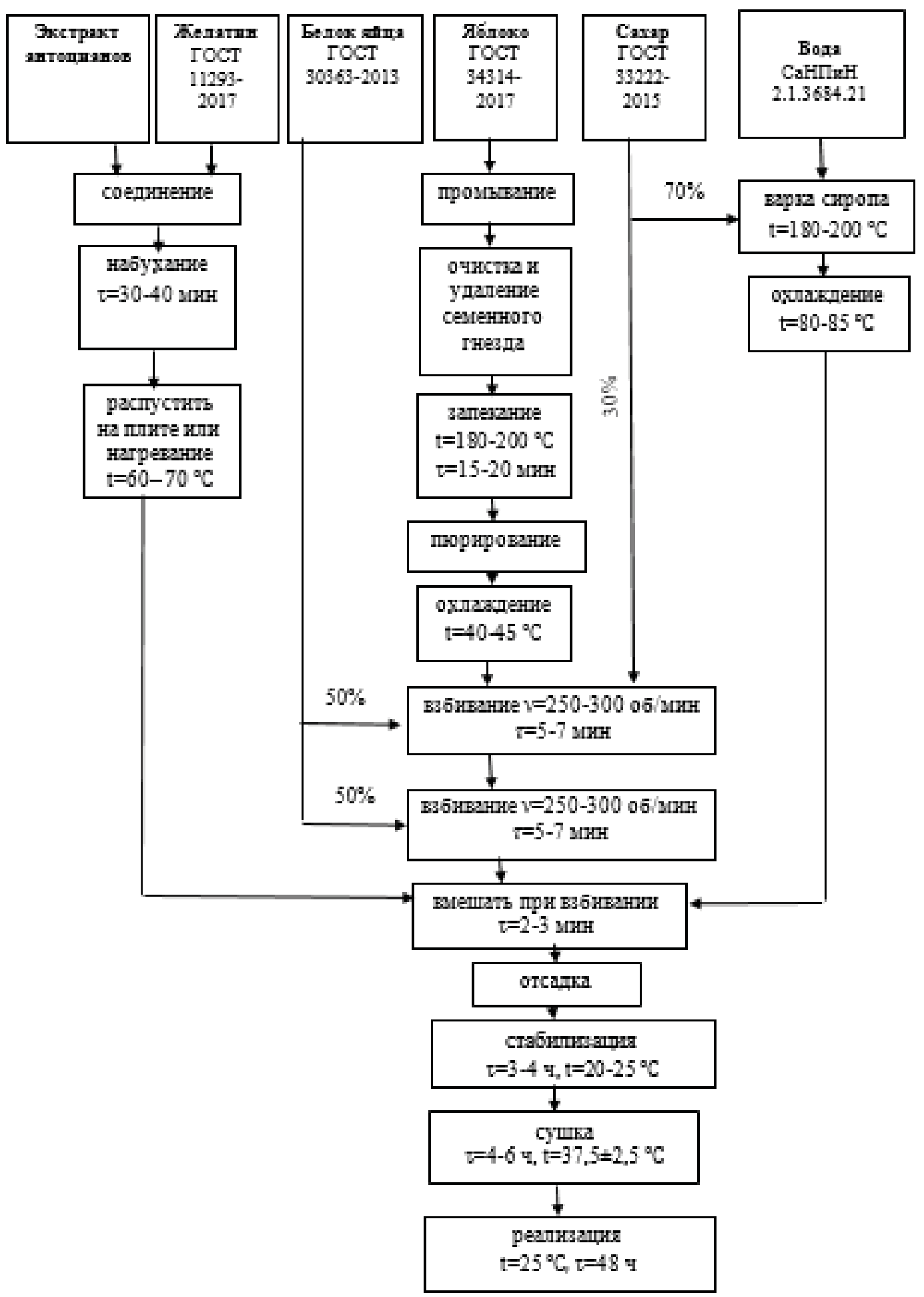

Puc. 4.3. Технологическая схема производства зефира с добавлением комплекса антоцианов и желатина 
Таблица 4.4

Влияние содержания антоцианов черной смородины

на органолептические показатели зефира

\begin{tabular}{|c|c|c|c|c|}
\hline $\begin{array}{c}\text { Показа- } \\
\text { тель }\end{array}$ & Без пигмента & $\begin{array}{c}\text { Содержание } \\
\text { комплекса } \\
11 \text { \% }\end{array}$ & $\begin{array}{c}\text { Содержание } \\
\text { комплекса } 13 \\
\%\end{array}$ & $\begin{array}{c}\text { Содержание } \\
\text { комплекса } \\
15 \text { \% }\end{array}$ \\
\hline $\begin{array}{l}\text { Внешний } \\
\text { вид }\end{array}$ & $\begin{array}{l}\text { Белая } \\
\text { воздушная } \\
\text { масса }\end{array}$ & $\begin{array}{l}\text { Светло-розовая, } \\
\text { воздушная } \\
\text { масса }\end{array}$ & $\begin{array}{l}\text { Розовая, } \\
\text { воздушная } \\
\text { масса }\end{array}$ & $\begin{array}{l}\text { Розовая, } \\
\text { воздушная } \\
\text { масса }\end{array}$ \\
\hline Цвет & Белый & $\begin{array}{l}\text { Насыщенный } \\
\text { розовый }\end{array}$ & $\begin{array}{l}\text { Выраженный } \\
\text { розово- } \\
\text { фиолетовый }\end{array}$ & $\begin{array}{l}\text { Интенсивный } \\
\text { фиолетовый }\end{array}$ \\
\hline $\begin{array}{l}\text { Консисте- } \\
\text { нция }\end{array}$ & $\begin{array}{l}\text { Пышная, од- } \\
\text { нородная }\end{array}$ & $\begin{array}{l}\text { Плотная, } \\
\text { однородная }\end{array}$ & $\begin{array}{l}\text { Пышная, од- } \\
\text { нородная }\end{array}$ & $\begin{array}{l}\text { Менее пышная, } \\
\text { однородная }\end{array}$ \\
\hline Запах & $\begin{array}{l}\text { Легкий запах } \\
\text { печеных } \\
\text { яблок }\end{array}$ & $\begin{array}{l}\text { Ощутимый } \\
\text { запах черной } \\
\text { смородины }\end{array}$ & $\begin{array}{l}\text { Выраженный } \\
\text { запах черной } \\
\text { смородины }\end{array}$ & $\begin{array}{l}\text { Выраженный } \\
\text { запах черной } \\
\text { смородины }\end{array}$ \\
\hline Вкус & Сладкий & $\begin{array}{l}\text { Невыраженный } \\
\text { кисло-сладкий } \\
\text { вкус }\end{array}$ & $\begin{array}{l}\text { Насыщенный } \\
\text { кисло-сладкий } \\
\text { вкус }\end{array}$ & $\begin{array}{l}\text { Насыщенный } \\
\text { кисло-сладкий } \\
\text { вкус }\end{array}$ \\
\hline $\begin{array}{l}\text { Формоус- } \\
\text { тойчи- } \\
\text { вость }\end{array}$ & $\begin{array}{l}\text { Имеет рав- } \\
\text { номерную } \\
\text { форму, } \\
\text { сохраняет } \\
\text { рисунок на } \\
\text { поверхности }\end{array}$ & $\begin{array}{l}\text { Имеет равно- } \\
\text { мерную форму, } \\
\text { сохраняет } \\
\text { рисунок на } \\
\text { поверхности }\end{array}$ & $\begin{array}{l}\text { Имеет равно- } \\
\text { мерную фор- } \\
\text { му, сохраняет } \\
\text { рисунок на } \\
\text { поверхности }\end{array}$ & $\begin{array}{l}\text { Расплывается, } \\
\text { не имеет четкой } \\
\text { формы, не сохра- } \\
\text { няет рисунок } \\
\text { на поверхности }\end{array}$ \\
\hline
\end{tabular}

Наилучшими органолептическими показателями обладал зефир с добавлением 13 \% комплекса желатина и антоцианов черной смородины. При данном содержании комплекса зефир приобретал интенсивно розовый цвет и приятный кисло-сладкий смородиновый вкус. Кроме того, зефир с добавлением комплекса антоцианов и желатина имел пышную однородную консистенцию и хорошую формоустойчивость.

Содержание антоцианов в 100 г исследуемых образцов зефира приведено в таблице 4.5. 
Содержание антоцианов, в 100 г зефира

\begin{tabular}{|c|}
\hline Содержание антоцианов в 100 г изделия, мг \\
\hline Черная смородина \\
\hline $35,25 \pm 1,15$ \\
\hline
\end{tabular}

Содержание антоцианов в зефире, приготовленном с использованием комплекса желатина и антоцианов черной смородины составляет 35,25 мг в 100 г изделия, соответственно.

Расчетным путем определялась функциональность зефира, приготовленного с использованием данных комплексов. Содержание антоцианов в 30 г зефира представлено в таблице 4.6.

Таблищуа 4.6

\section{Степень удовлетворения}

суточной потребности организма в антоцианах

\begin{tabular}{|l|c|}
\hline \multicolumn{1}{|c|}{ Продукт } & $\begin{array}{c}\text { Содержание антоцианов в 30 г зефира, } \\
\text { \% от суточной нормы потребления }\end{array}$ \\
\hline $\begin{array}{l}\text { Зефир с добавлением комплекса } \\
\text { желатина и антоцианов черной } \\
\text { смородины }\end{array}$ & 21 \\
\hline
\end{tabular}

Следовательно, зефир, приготовленный с использованием комплексов желатина и антоцианов черной смородины можно считать ФПП, поскольку содержание в нем антоцианов составляет более $15 \%$ от суточной нормы потребления.

Зефир с добавлением антоцианового красителя, содержащего комплекс антоцианов и яичного альбумина, готовили по унифицированной рецептуре в соответствии с классической технологией [15], заменяя воду на экстракт антоцианов. Было приготовлено четыре образца зефира, содержащего 11-14 \% комплексов антоцианов и яичного альбумина.

Органолептическая оценка образцов зефира с добавлением комплекса антоцианов черной смородины и яичного альбумина представлена в таблице 4.7. В качестве контроля использовали зефир без добавления комплекса. 
Таблийа 4.7

\section{Органолептическая оценка образцов зефира \\ с добавлением комплекса антоцианов черной смородины \\ и яичного альбумина}

\begin{tabular}{|c|c|c|c|c|c|}
\hline $\begin{array}{c}\text { Наиме- } \\
\text { нование } \\
\text { показате- } \\
\text { ля }\end{array}$ & Контроль & $\begin{array}{c}11 \text { \% ком- } \\
\text { плекс анто- } \\
\text { цианов и } \\
\text { яичного } \\
\text { альбумина }\end{array}$ & $\begin{array}{c}12 \text { \% ком- } \\
\text { плекс анто- } \\
\text { цианов и } \\
\text { яичного } \\
\text { альбумина }\end{array}$ & $\begin{array}{c}13 \text { \% ком- } \\
\text { плекс анто- } \\
\text { цианов и } \\
\text { яичного } \\
\text { альбумина }\end{array}$ & $\begin{array}{c}14 \text { \% ком- } \\
\text { плекс анто- } \\
\text { цианов и } \\
\text { яичного } \\
\text { альбумина }\end{array}$ \\
\hline $\begin{array}{l}\text { Внешний } \\
\text { вид }\end{array}$ & $\begin{array}{l}\text { Белая воз- } \\
\text { душная } \\
\text { масса }\end{array}$ & $\begin{array}{l}\text { Розовая } \\
\text { воздушная } \\
\text { масса }\end{array}$ & $\begin{array}{l}\text { Розовая } \\
\text { воздушная } \\
\text { масса }\end{array}$ & $\begin{array}{l}\text { Розовая } \\
\text { воздушная } \\
\text { масса }\end{array}$ & $\begin{array}{l}\text { Бледно- } \\
\text { розовая воз- } \\
\text { душная } \\
\text { масса }\end{array}$ \\
\hline $\begin{array}{l}\text { Формоус- } \\
\text { тойчи- } \\
\text { вость }\end{array}$ & $\begin{array}{l}\text { Имеет } \\
\text { равномер- } \\
\text { ную фор- } \\
\text { му, сохра- } \\
\text { няет рису- } \\
\text { нок на по- } \\
\text { верхности }\end{array}$ & $\begin{array}{l}\text { Расплыва- } \\
\text { ется, не } \\
\text { имеет чет- } \\
\text { кой формы, } \\
\text { не сохраня- } \\
\text { ет рисунок } \\
\text { на поверх- } \\
\text { ности }\end{array}$ & $\begin{array}{l}\text { Имеет рав- } \\
\text { номерную } \\
\text { форму, со- } \\
\text { храняет ри- } \\
\text { сунок на } \\
\text { поверхно- } \\
\text { сти }\end{array}$ & $\begin{array}{l}\text { Имеет рав- } \\
\text { номерную } \\
\text { форму, со- } \\
\text { храняет ри- } \\
\text { сунок на } \\
\text { поверхно- } \\
\text { сти }\end{array}$ & $\begin{array}{l}\text { Расплывает- } \\
\text { ся, не имеет } \\
\text { четкой } \\
\text { формы, не } \\
\text { сохраняет } \\
\text { рисунок на } \\
\text { поверхности }\end{array}$ \\
\hline Цвет & Белый & $\begin{array}{l}\text { Выражен- } \\
\text { ный розо- } \\
\text { вый }\end{array}$ & $\begin{array}{l}\text { Выражен- } \\
\text { ный розово }\end{array}$ & $\begin{array}{l}\text { Выражен- } \\
\text { ный розово- } \\
\text { фиолетовый }\end{array}$ & $\begin{array}{l}\text { Бледно ро- } \\
\text { зовый }\end{array}$ \\
\hline $\begin{array}{l}\text { Конси- } \\
\text { стенция }\end{array}$ & $\begin{array}{l}\text { Воздушная } \\
\text { однород- } \\
\text { ная }\end{array}$ & $\begin{array}{l}\text { Жидкая од- } \\
\text { нородная }\end{array}$ & $\begin{array}{l}\text { Воздушная } \\
\text { однородная }\end{array}$ & $\begin{array}{l}\text { Воздушная } \\
\text { однородная }\end{array}$ & $\begin{array}{l}\text { Жидкая, } \\
\text { неоднород- } \\
\text { ная с вклю- } \\
\text { чениями ко- } \\
\text { агулирован- } \\
\text { ного белка }\end{array}$ \\
\hline Запах & $\begin{array}{l}\text { Легкий за- } \\
\text { пах пече- } \\
\text { ных яблок }\end{array}$ & $\begin{array}{l}\text { Выражен- } \\
\text { ный запах } \\
\text { черной } \\
\text { смородины }\end{array}$ & $\begin{array}{l}\text { Выражен- } \\
\text { ный запах } \\
\text { черной } \\
\text { смородины }\end{array}$ & $\begin{array}{l}\text { Выражен- } \\
\text { ный запах } \\
\text { черной } \\
\text { смородины }\end{array}$ & $\begin{array}{l}\text { Выражен- } \\
\text { ный запах } \\
\text { черной смо- } \\
\text { родины и } \\
\text { яичного } \\
\text { альбумина }\end{array}$ \\
\hline Вкус & Сладкий & $\begin{array}{l}\text { Насыщен- } \\
\text { ный кисло- } \\
\text { сладкий } \\
\text { вкус }\end{array}$ & $\begin{array}{l}\text { Насыщен- } \\
\text { ный кисло- } \\
\text { сладкий } \\
\text { вкус }\end{array}$ & $\begin{array}{l}\text { Насыщен- } \\
\text { ный кисло- } \\
\text { сладкий } \\
\text { вкус с гор- } \\
\text { чинкой }\end{array}$ & $\begin{array}{l}\text { Насыщен- } \\
\text { ный кисло- } \\
\text { сладкий } \\
\text { вкус с гор- } \\
\text { чинкой }\end{array}$ \\
\hline
\end{tabular}


Наилучшими органолептическими показателями обладал зефир с добавлением 13 \% комплекса, содержащего антоцианы черной смородины и яичного альбумина. При данном содержании комплекса антоцианов и ячного альбумина зефир приобретал розово-фиолетовый и насыщенный кисло-сладкий смородиновый вкус. Кроме того, зефир с добавлением комплекса антоцианов и яичного альбумина, имел пышную однородную консистенцию и хорошую формоустойчивость.

Содержание антоцианов в 100 г исследуемых образцов зефира приведено в таблице 4.8 .

Таблица 4.8

\section{Содержание антоцианов в 100 г изделия}

\begin{tabular}{|c|}
\hline Содержание антоцианов в 100 г изделия, мг \\
\hline Смородина \\
\hline $30,45 \pm 1,04$ \\
\hline
\end{tabular}

Из таблицы 4.8 видно, что содержание антоцианов в зефире, приготовленном с использованием комплекса яичный альбумин и антоцианы черной смородины составляет 30,45 в 100 г изделия.

Расчетным путем определялась функциональность зефира, приготовленного с использованием комплексов яичный альбумин и антоцианы черной смородины. Содержание антоцианов в 30 г зефира представлено в таблице 4.9.

Таблица 4.9

\section{Степень удовлетворения}

\section{суточной потребности организма в антоцианах}

\begin{tabular}{|l|c|}
\hline \multicolumn{1}{|c|}{ Продукт } & $\begin{array}{c}\text { Содержание антоцианов в 30 г зефира, } \\
\text { \% от суточной нормы потребления }\end{array}$ \\
\hline $\begin{array}{l}\text { Зефир с добавлением комплекса } \\
\text { яичного альбумина и антоцианов } \\
\text { черной смородины }\end{array}$ & 18,27 \\
\hline
\end{tabular}

Следовательно, зефир, приготовленный с использованием антоцианового красителя, содержащего комплекс антоцианов и яичного 
альбумина, можно считать ФПП, поскольку содержание в нем антоцианов составляет более 15 \% от суточной нормы потребления.

Таким образом, антоциановый краситель, содержащий комплекс антоцианов и белков, может быть использован для создания функциональных пастильных изделий, обогащая их биологически активными соединениями и улучшая их органолептические свойства.

\subsection{3. Использования антоцианового красителя в производстве масложировых композиций отделочных полуфабрикатов}

В данной работе рассмотрена возможность использования водных антоциановых экстрактов, а также водорастворимого концентрированного антоцианового красителя в производстве сливочных кремов.

\subsubsection{1. Применение окраменного антоциинсодержащего структурообразователя в производстве сливочных кремов}

В производстве крема сливочного основного для придания продукту привлекательного цвета и выраженного ягодного вкуса, использовались водные растворы антоцианов, выделенных из культивированного - черной смородины (Ríbes nígrum) и дикорастущего ягодного сырья Дальневосточного региона - калины обыкновенной (Viburnum opulus), брусники (Vaccinium vitis-idaea L.) и лимонника китайского (Schisándra chinénsis).

Крем сливочный основной готовили по унифицированной рецептуре в соответствии с классической технологией [14]. С целью возможности введения водного раствора антоцианов в жировую фазу крема был приготовлен раствор окрашенного структурообразователя, содержащего антоцианы, эмульгатор и студнеобразователь.

В качестве эмульгатора для получения раствора окрашенного структурообразователя использовали лецитин. В водный экстракт антоцианов было добавлено 3, 7 и 9 мас. \% лецитина. Наилучшие органолептические показатели имел раствор антоцианов, содержащий 7 мас. \% лецитина. Раствор обладал насыщенной окраской, ярко выраженным ягодным вкусом и однородной консистенцией. 
Для стабильности раствора окрашенного структурообразователя вводили загуститель каррагинан в количестве 0,5, 1,5 и 2 мас. \%. Добавление каррагинана повышало вязкость раствора и делало эмульсию более стабильной. Наилучшими органолептическими показателями обладал раствор окрашенного структурообразователя, содержащий 2 мас. \% каррагинана. Раствор, обладал пышной, однородной и пластичной консистенцией, насыщенным цветом и выраженным ягодным вкусом. Технологическая схема приготовления раствора окрашенного структурообразователя представлена на рисунке 4.4 .

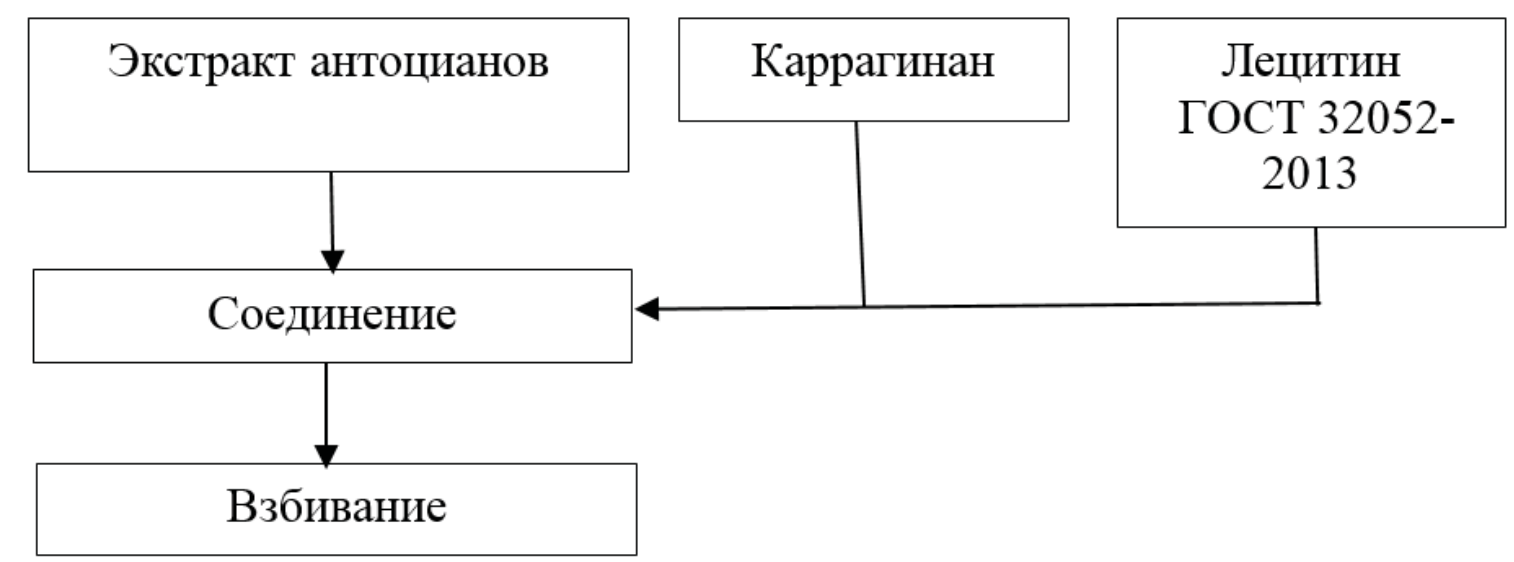

Puc.4.4. Технологическая схема приготовления раствора окрашенного структурообразователя

Приготовленный раствор окрашенного структурообразователя, содержащего экстракт антоцианов, 7 мас. \% лецитина и 2 мас. \% каррагинана, вводили в массу крема на стадии его взбивания.

С целью определения содержания окрашенного структурообразователя в изделии, было приготовлено 4 образца крема сливочного основного, содержащих 11, 13, 15 и 17 мас. \% окрашенного структурообразователя. В качестве контроля использовали крем сливочный основной, без добавления раствора окрашенного структурообразователя. Технологическая схема приготовления крема сливочного основного с добавлением окрашенного структурообразователя представлена на рисунке 4.5 . 


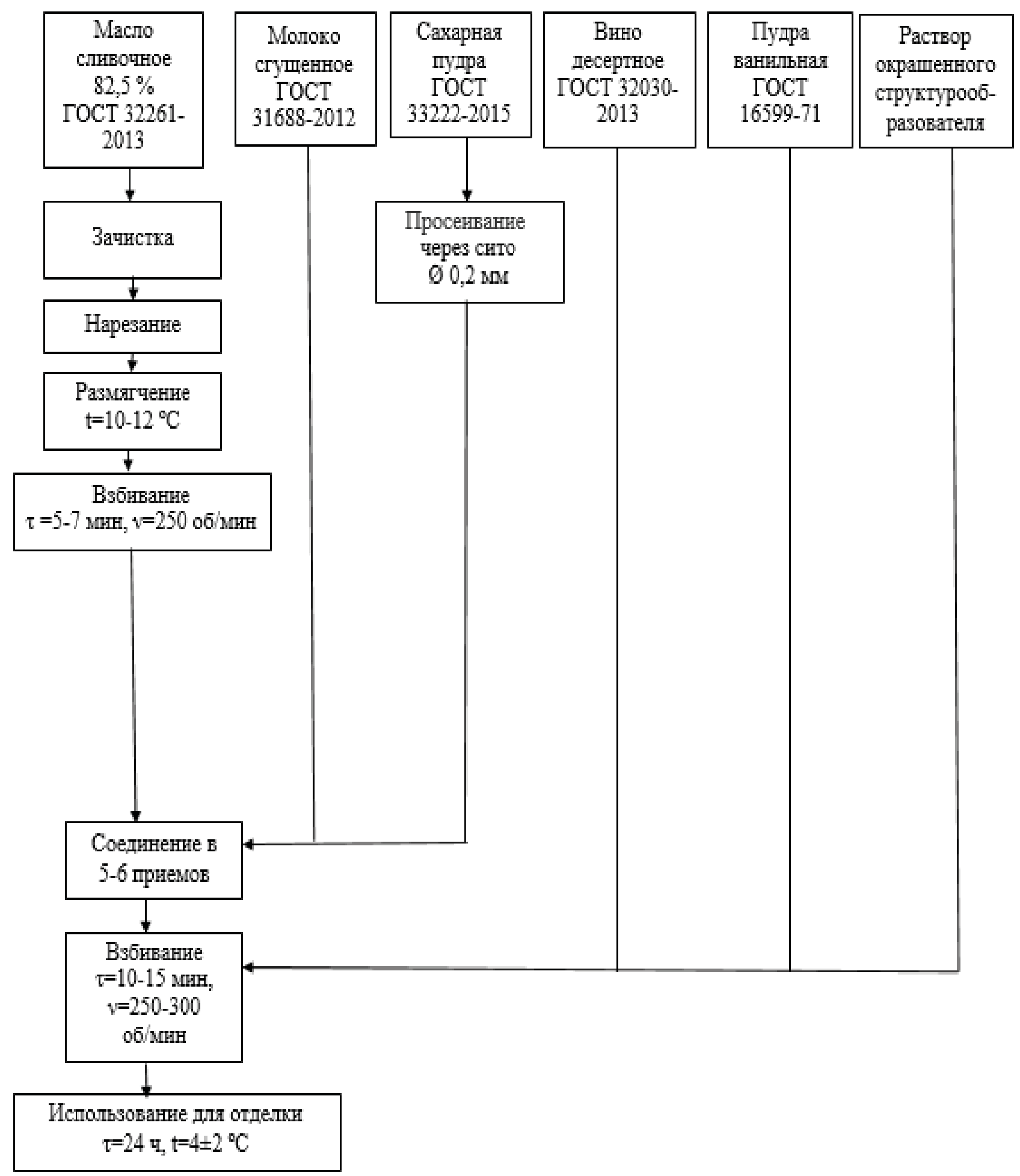

Puc. 4.5. Технологическая схема приготовления крема сливочного основного с добавлением окрашенного структурообразователя

Органолептическая оценка образцов крема сливочного основного с различным содержанием окрашенного структурообразователя представлена в таблице 4.10. 


\section{Органолептическая оценка образцов крема}

\section{сливочного основного с различным содержанием}

окрашенного структурообразователя

\begin{tabular}{|c|c|c|c|c|c|}
\hline \multirow{2}{*}{$\begin{array}{c}\text { Показа- } \\
\text { тель }\end{array}$} & \multicolumn{5}{|c|}{ Количество раствора окрашенного структурообразователя, мас. \% } \\
\hline & Контроль & 11 & 13 & 15 & 17 \\
\hline $\begin{array}{l}\text { Внеш- } \\
\text { ний вид }\end{array}$ & $\begin{array}{l}\text { пышная } \\
\text { однород- } \\
\text { ная масса } \\
\text { молочного } \\
\text { цвета, хо- } \\
\text { рошо дер- } \\
\text { жит форму } \\
\text { и рисунок }\end{array}$ & $\begin{array}{l}\text { пышная од- } \\
\text { нородная } \\
\text { масса свет- } \\
\text { ло-розового } \\
\text { цвета, не } \\
\text { достаточно } \\
\text { хорошо } \\
\text { держит } \\
\text { форму и ри- } \\
\text { сунок }\end{array}$ & $\begin{array}{l}\text { пышная } \\
\text { однород- } \\
\text { ная масса } \\
\text { розового } \\
\text { цвета, хо- } \\
\text { рошо дер- } \\
\text { жит форму } \\
\text { и рисунок }\end{array}$ & $\begin{array}{l}\text { пышная од- } \\
\text { нородная } \\
\text { масса ярко- } \\
\text { розового } \\
\text { цвета, хо- } \\
\text { рошо дер- } \\
\text { жит форму } \\
\text { и рисунок }\end{array}$ & $\begin{array}{l}\text { однородная } \\
\text { масса темно- } \\
\text { розового цве- } \\
\text { та, хорошо } \\
\text { держит форму } \\
\text { и рисунок }\end{array}$ \\
\hline Цвет & молочный & $\begin{array}{l}\text { светло- } \\
\text { розовый }\end{array}$ & розовый & $\begin{array}{l}\text { от розового } \\
\text { до ярко- } \\
\text { розового }\end{array}$ & $\begin{array}{l}\text { темно- } \\
\text { розовый }\end{array}$ \\
\hline $\begin{array}{l}\text { Конси- } \\
\text { сте-нция }\end{array}$ & $\begin{array}{l}\text { пышная, } \\
\text { однород- } \\
\text { ная,очень } \\
\text { пластич- } \\
\text { ная }\end{array}$ & $\begin{array}{l}\text { пышная, } \\
\text { однородная, } \\
\text { недостаточ- } \\
\text { но пластич- } \\
\text { ная }\end{array}$ & $\begin{array}{l}\text { пышная, } \\
\text { однород- } \\
\text { ная, } \\
\text { пластич- } \\
\text { ная }\end{array}$ & $\begin{array}{l}\text { пышная, } \\
\text { однородная } \\
\text { очень пла- } \\
\text { стичная }\end{array}$ & $\begin{array}{l}\text { однородная, } \\
\text { немного плот- } \\
\text { новатая }\end{array}$ \\
\hline Запах & сливочный & сливочный & сливочный & $\begin{array}{l}\text { слабо вы- } \\
\text { раженный } \\
\text { аромат } \\
\text { ягодного } \\
\text { сырья }\end{array}$ & $\begin{array}{l}\text { выраженный } \\
\text { ягодного сы- } \\
\text { рья }\end{array}$ \\
\hline Вкус & $\begin{array}{l}\text { сливочно- } \\
\text { сладкий }\end{array}$ & $\begin{array}{l}\text { сливочный } \\
\text { со слабовы- } \\
\text { раженным } \\
\text { вкусом } \\
\text { ягодного } \\
\text { сырья }\end{array}$ & $\begin{array}{l}\text { сливочный } \\
\text { с легким } \\
\text { привкусом } \\
\text { ягодного } \\
\text { сырья }\end{array}$ & $\begin{array}{l}\text { характер- } \\
\text { ный кисло- } \\
\text { сладкий } \\
\text { привкус } \\
\text { ягодного } \\
\text { сырья }\end{array}$ & $\begin{array}{l}\text { ярко выра- } \\
\text { женный кис- } \\
\text { ло-сладкий } \\
\text { привкус ягод- } \\
\text { ного сырья }\end{array}$ \\
\hline
\end{tabular}


Из представленных результатов видно, что наилучшие органолептические показатели имели образцы крема сливочного основного с добавлением 15 мас. \% окрашенного структурообразователя. Крем сливочный основной с добавлением 15 мас. \% окрашенного структурообразователя приобретал приятный ярко-розовый цвет, имел выраженный вкус ягодного сырья и пышную однородную и очень пластичную консистенцию.

Органолептическая оценка образцов крема сливочного основного с добавлением 15 мас. \% окрашенного структурообразователя, содержащего антоцианы, выделенные из ягод смородины, брусники, калины и лимонника, представлена в таблице 4.11 .

Таблица 4.11

\section{Органолептическая оценка образцов крема} сливочного основного с добавлением 15 мас. \% окрашенного структурообразователя

\begin{tabular}{|c|c|c|c|c|}
\hline \multirow[t]{2}{*}{ Показатель } & \multicolumn{4}{|c|}{$\begin{array}{c}\text { Образцы крема, с добавлением } 15 \text { мас. \% } \\
\text { окрашенного структурообразователя }\end{array}$} \\
\hline & смородина & брусника & калина & ЛИМОНник \\
\hline $\begin{array}{l}\text { Внешний } \\
\text { Вид }\end{array}$ & $\begin{array}{l}\text { пышная одно- } \\
\text { родная масса } \\
\text { розово- } \\
\text { фиолетового } \\
\text { цвета, хорошо } \\
\text { держит форму } \\
\text { и рисунок }\end{array}$ & $\begin{array}{l}\text { пышная одно- } \\
\text { родная масса } \\
\text { розово- } \\
\text { фиолетового } \\
\text { цвета, хорошо } \\
\text { держит форму } \\
\text { и рисунок }\end{array}$ & $\begin{array}{l}\text { пышная одно- } \\
\text { родная масса } \\
\text { розового цве- } \\
\text { та, хорошо } \\
\text { держит форму } \\
\text { и рисунок }\end{array}$ & $\begin{array}{l}\text { пышная одно- } \\
\text { родная масса } \\
\text { розового цве- } \\
\text { та, хорошо } \\
\text { держит форму } \\
\text { и рисунок }\end{array}$ \\
\hline Цвет & $\begin{array}{l}\text { розово- } \\
\text { фиолетовый }\end{array}$ & ярко-розовый & розовый & розовый \\
\hline $\begin{array}{l}\text { Консистен- } \\
\text { ция }\end{array}$ & $\begin{array}{l}\text { пышная, од- } \\
\text { нородная, } \\
\text { очень пла- } \\
\text { стичная }\end{array}$ & $\begin{array}{l}\text { пышная, од- } \\
\text { нородная, } \\
\text { очень пла- } \\
\text { стичная }\end{array}$ & $\begin{array}{l}\text { пышная, од- } \\
\text { нородная, } \\
\text { очень пла- } \\
\text { стичная }\end{array}$ & $\begin{array}{l}\text { пышная, од- } \\
\text { нородная, } \\
\text { очень пла- } \\
\text { стичная }\end{array}$ \\
\hline Запах & $\begin{array}{l}\text { слабо выра- } \\
\text { женный аро- } \\
\text { мат смороди- } \\
\text { ны }\end{array}$ & $\begin{array}{l}\text { слабо выра- } \\
\text { женный аро- } \\
\text { мат брусники }\end{array}$ & $\begin{array}{l}\text { слабо выра- } \\
\text { женный аро- } \\
\text { мат калины }\end{array}$ & $\begin{array}{l}\text { слабо выра- } \\
\text { женный аро- } \\
\text { мат лимонни- } \\
\text { ка }\end{array}$ \\
\hline Вкус & $\begin{array}{l}\text { характерный } \\
\text { кисло-сладкий }\end{array}$ & $\begin{array}{l}\text { характерный } \\
\text { кисло-сладкий }\end{array}$ & $\begin{array}{l}\text { характерный } \\
\text { кисло-сладкий } \\
\text { с легкой горе- } \\
\text { чью }\end{array}$ & $\begin{array}{l}\text { характерный } \\
\text { кисло-сладкий }\end{array}$ \\
\hline
\end{tabular}


Образцы крема сливочного основного с добавлением окрашенного структурообразователя имели приятный розовый, ярко-розовый и розово-фиолетовый цвет. Кроме того, образцы крема с добавлением окрашенного структурообразователя смородины, брусники и лимонника имели приятный кисло-сладкий вкус, с антоцианами калины к кисло-сладкому вкусу добавлялась легкая горечь.

Содержание антоцианов, выделенных из ягодного сырья, в 100 г исследуемых образцов крема приведено в таблице 4.12.

Таблицุа 4.12

\section{Содержание антоцианов,}

выделенных из ягодного сырья, В 100 г крема

\begin{tabular}{|l|c|c|c|c|}
\hline \multirow{2}{*}{\multicolumn{1}{|c|}{ Способ выделения }} & \multicolumn{4}{|c|}{$\begin{array}{c}\text { Содержание антоцианов, выделенных } \\
\text { из ягодного сырья, в 100 г крема, мг }\end{array}$} \\
\cline { 2 - 5 } & смородина & брусника & калина & лимонник \\
\hline $\begin{array}{l}\text { Экстрагирование водным } \\
\text { раствором при } 65{ }^{\circ} \mathrm{C}\end{array}$ & $44,34 \pm 3,05$ & $17,04 \pm 1,56$ & $3,63 \pm 1,06$ & $23,53 \pm 3,34$ \\
\hline Ультразвуковая экстракция & $36,90 \pm 2,15$ & $11,00 \pm 1,23$ & $3,20 \pm 1,22$ & $16,90 \pm 1,08$ \\
\hline
\end{tabular}

Содержание антоцианов в образцах крема сливочного основного, выделенных из ягод смородины, брусники, калины и лимонника, при температуре $65{ }^{\circ} \mathrm{C}$, составляло 44,34, 17,04, 3,63, 21,53 мг, выделенного в процессе ультразвуковой экстракции - 36,9, 11,0, 3,2 и 6,9 мг в 100 г продукта, соответственно.

Расчетным методом определялось можно ли крем сливочный основной с добавлением окрашенного структурообразователя, содержащего антоцианы ягод смородины, брусники, калины и лимонника рассматривать как ФПП. Содержание антоцианов в 45 г крема сливочного основного представлено в таблице 4.13 .

Следовательно, образцы крема сливочного основного с добавлением окрашенного структурообразователя, содержащего антоцианы ягод черной смородины, брусники и лимонника можно считать ФПП, поскольку содержание в них антоцианов составляет более 15 \% от суточной нормы потребления. 


\section{Степень удовлетворения}

суточной потребности организма в антоцианах

\begin{tabular}{|c|c|c|c|c|}
\hline \multirow[t]{2}{*}{ Продукт } & \multicolumn{4}{|c|}{$\begin{array}{c}\text { Содержание антоцианов в } 45 \text { г крема \% } \\
\text { от суточной нормы потребления }\end{array}$} \\
\hline & $\begin{array}{c}\text { черная } \\
\text { смородина }\end{array}$ & брусника & калина & лимонник \\
\hline $\begin{array}{l}\text { Крем сливочный основной } \\
\text { с добавлением окрашенного } \\
\text { структурообразователя } \\
\text { (Экстрагирование антоцианов } \\
\text { водным раствором при } 65^{\circ} \mathrm{C} \text { ) }\end{array}$ & 40 & 16 & 3 & 21 \\
\hline $\begin{array}{l}\text { Крем сливочный основной } \\
\text { с добавлением окрашенного } \\
\text { структурообразователя } \\
\text { (Ультразвуковая экстракция } \\
\text { антоцианов) }\end{array}$ & 33 & 15 & 2 & 15 \\
\hline
\end{tabular}

Таким образом, использование 15 мас. \% окрашенного структурообразователя, содержащего антоцианы, при производстве крема сливочного основного придает продукту приятный розово-фиолетовый или розовый цвет и имеет характерный кисло-сладкий или кисло-сладкий с легкой горечью вкус. Добавление 15 мас. \% окрашенного структурообразователя, содержащего антоцианы, выделенные из ягодного сырья, в рецептуру крема позволяет получать стабильный эмульсионный продукт с пышной однородной, очень пластичной консистенцией, крем хорошо держит форму и рисунок. Кроме того, образцы окрашенного структурообразователя, содержащего антоцианы черной смородины, брусники и лимонника можно использовать для производства функциональных отделочных полуфабрикатов, содержащих в своем составе биологически активные соединения. 


\subsubsection{2. Применение концентрированного}

антоцианового красителя в производстве сливочных кремов

В качестве источника для получения концентрированного антоцианового красителя использовалось редко применяемое в пищевой промышленности дикорастущее сырье Дальневосточного региона - ягоды красники (Vaccinium praestans) и лимонника китайского (Schisándra chinénsis). Технологическая схема получения концентрированного антоцианового красителя, включающая мягкий кислотный гидролиз лимонной кислотой, обработку 95 \% этанолом и концентрирование более плотной, вязкой фракции на вакуумном (роторном) испарителе, представлена на рисунке 3.6.

В данной работе концентрированный антоциановый краситель использовали в качестве натурального безопасного красителя для окрашивания масложирового отделочного полуфабриката - крема сливочного основного. Использование водорастворимого концентрированного антоцианового красителя позволяет не только повысить органолептические показатели крема, но и исключить дополнительное введение в рецептуру стабилизатора и эмульгатора, используемых для создания стабильной эмульсии, поскольку концентрированный антоциановый краситель содержит в своем составе пектиновые вещества, обладающие структурообразующими и поверхностноактивными свойствами [4, 8].

Крем сливочный основной готовили по унифицированной рецептуре в соответствии с классической технологией [14]. Концентрированный антоциановый краситель вводили в массу крема на стадии его взбивания.

С целью определения количества красителя, добавляемого в изделие, было приготовлено 4 образца крема сливочного основного, содержащих 13, 15 и 17 мас. \% концентрированного красителя красники и лимонника. В качестве контроля использовали крем сливочный основной без его добавления.

Органолептическая оценка образцов крема сливочного основного с различным содержанием концентрированного антоцианового красителя красники и лимонника представлена в таблицах 4.14 и 4.15. 


\section{Органолептическая оценка образцов крема сливочного основного с различным содержанием концентрированного}

\section{антоцианового красителя красники}

\begin{tabular}{|c|c|c|c|c|}
\hline \multirow[t]{2}{*}{$\begin{array}{l}\text { Показа- } \\
\text { тель }\end{array}$} & \multirow{2}{*}{$\begin{array}{c}\text { Без до- } \\
\text { бавления } \\
\text { красителя }\end{array}$} & \multicolumn{3}{|c|}{$\begin{array}{c}\text { Количество концентрированного антоцианового } \\
\text { красителя красники, добавленного в крем, \% }\end{array}$} \\
\hline & & 10 & 15 & 17 \\
\hline $\begin{array}{l}\text { Внешний } \\
\text { вид }\end{array}$ & $\begin{array}{l}\text { Пышная } \\
\text { однород- } \\
\text { ная масса }\end{array}$ & $\begin{array}{l}\text { Пышная } \\
\text { однородная } \\
\text { масса }\end{array}$ & $\begin{array}{l}\text { Пышная } \\
\text { однородная масса }\end{array}$ & $\begin{array}{l}\text { Пышная } \\
\text { однородная масса }\end{array}$ \\
\hline Цвет & $\begin{array}{l}\text { Молоч- } \\
\text { ный }\end{array}$ & Розовый & Ярко розовый & Ярко красный \\
\hline $\begin{array}{l}\text { Консис- } \\
\text { тенция }\end{array}$ & $\begin{array}{l}\text { Пышная, } \\
\text { однород- } \\
\text { ная }\end{array}$ & $\begin{array}{l}\text { Пышная, } \\
\text { однородная }\end{array}$ & $\begin{array}{l}\text { Пышная, } \\
\text { однородная }\end{array}$ & $\begin{array}{l}\text { Немного } \\
\text { плотноватая } \\
\text { однородная }\end{array}$ \\
\hline Запах & $\begin{array}{l}\text { Сливоч- } \\
\text { ный }\end{array}$ & $\begin{array}{l}\text { Сливочный со } \\
\text { слабым аро- } \\
\text { матом } \\
\text { красники }\end{array}$ & $\begin{array}{l}\text { Сливочный } \\
\text { с выраженным } \\
\text { ароматом } \\
\text { красники }\end{array}$ & $\begin{array}{l}\text { Сливочный } \\
\text { со слабым } \\
\text { ароматом } \\
\text { лимонника }\end{array}$ \\
\hline Вкус & $\begin{array}{l}\text { Сливоч- } \\
\text { но- } \\
\text { сладкий }\end{array}$ & $\begin{array}{l}\text { Сливочный } \\
\text { с легкой } \\
\text { кислинкой }\end{array}$ & $\begin{array}{l}\text { Сладкий } \\
\text { с кислинкой, } \\
\text { выраженный вкус } \\
\text { красники }\end{array}$ & $\begin{array}{l}\text { Сливочный } \\
\text { с легкой } \\
\text { кислинкой }\end{array}$ \\
\hline
\end{tabular}

Таблица 4.15

\section{Органолептическая оценка образцов крема сливочного основного с различным содержанием концентрированного антоцианового красителя лимонника}

\begin{tabular}{|l|l|l|l|l|}
\hline \multirow{2}{*}{$\begin{array}{c}\text { Показа- } \\
\text { тель }\end{array}$} & $\begin{array}{c}\text { Без до- } \\
\text { бавления } \\
\text { красителя }\end{array}$ & \multicolumn{3}{|c|}{$\begin{array}{r}\text { Количество концентрированного антоцианового } \\
\text { красителя, добавленного в крем, \% }\end{array}$} \\
\cline { 3 - 5 } $\begin{array}{l}\text { Внешний } \\
\text { вид }\end{array}$ & $\begin{array}{l}\text { Пышная } \\
\text { однород- } \\
\text { ная масса }\end{array}$ & $\begin{array}{l}\text { Пышная } \\
\text { однородная }\end{array}$ & $\begin{array}{l}\text { Пышная } \\
\text { однородная масса }\end{array}$ & $\begin{array}{l}\text { Пышная } \\
\text { однородная масса }\end{array}$ \\
\hline Цвет & $\begin{array}{l}\text { Молоч- } \\
\text { ный }\end{array}$ & Коралловый & $\begin{array}{l}\text { Насыщенный } \\
\text { коралловый }\end{array}$ & $\begin{array}{l}\text { Насыщенный } \\
\text { коралловый }\end{array}$ \\
\hline
\end{tabular}


Окончание табл. 4.15

\begin{tabular}{|l|l|l|l|l|}
\hline $\begin{array}{l}\text { Конси- } \\
\text { стенция }\end{array}$ & $\begin{array}{l}\text { Пышная, } \\
\text { одно- } \\
\text { родная }\end{array}$ & $\begin{array}{l}\text { Пышная, од- } \\
\text { нородная }\end{array}$ & $\begin{array}{l}\text { Пышная, } \\
\text { однородная }\end{array}$ & $\begin{array}{l}\text { Немного плотно- } \\
\text { ватая однородная }\end{array}$ \\
\hline Запах & $\begin{array}{l}\text { Сливоч- } \\
\text { ный }\end{array}$ & $\begin{array}{l}\text { Сливочный с } \\
\text { выраженным } \\
\text { ароматом } \\
\text { красники }\end{array}$ & $\begin{array}{l}\text { Сливочный } \\
\text { с ароматом } \\
\text { лимонника }\end{array}$ & $\begin{array}{l}\text { Сливочный } \\
\text { с ароматом } \\
\text { лимонника }\end{array}$ \\
\hline Вкус & $\begin{array}{l}\text { Сливоч- } \\
\text { но- } \\
\text { сладкий }\end{array}$ & $\begin{array}{l}\text { Сливочный с } \\
\text { легкой кис- } \\
\text { линкой }\end{array}$ & $\begin{array}{l}\text { Сладкий } \\
\text { с кислинкой, } \\
\text { выраженный вкус } \\
\text { лимонника }\end{array}$ & $\begin{array}{l}\text { Сладкий с кислин- } \\
\text { кой, выраженный } \\
\text { вкус лимонника }\end{array}$ \\
\hline
\end{tabular}

Из, полученных результатов видно, что наилучшими органолептическими показателями обладали образцы крема сливочного основного с добавлением 15 мас. \% концентрированного антоцианового красителя. Крем сливочный основной с добавлением 15 мас. \% концентрированного антоцианового красителя красники и лимонника приобретал приятный ярко-розовый или насыщенный коралловый цвет, имел выраженный вкус ягодного сырья и пышную однородную и очень пластичную консистенцию.

Содержание антоцианового пигмента, выделенного из ягодного сырья, в 100 г исследуемых образцов крема приведено в таблице 4.16.

Таблицьа 4.16

\section{Содержание антоцианов в 100 г крема}

\begin{tabular}{|c|c|}
\hline \multicolumn{2}{|c|}{ Содержание антоцианов, выделенных } \\
из ягодного сырья, в 100 г крема, мг \\
\hline Красника & Лимонник \\
\hline $61,55 \pm 4,15$ & $53,56 \pm 2,45$ \\
\hline
\end{tabular}

Содержание антоцианов в креме сливочном, приготовленном с добавлением концентрированного антоцианового красителя красники и лимонника, составляет 61,55 и 53,56 мг в 100 г изделия, соответственно. 
Расчетным методом определялось можно ли крем сливочный основной с добавлением концентрированного антоцианового красителя рассматривать как ФПП. Содержание антоцианов в 45 г крема сливочного основного представлено в таблице 4.17.

Таблица 4.17

\section{Степень удовлетворения}

суточной потребности организма в антоцианах

\begin{tabular}{|l|c|}
\hline \multicolumn{1}{|c|}{ Продукт } & $\begin{array}{c}\text { Содержание антоцианов в 45 г крема, } \\
\text { \% от суточной нормы потребления }\end{array}$ \\
\hline Красника & 55 \\
\hline Лимонник & 48 \\
\hline
\end{tabular}

Следовательно, крем сливочный основной с добавлением концентрированного антоцианового красителя ягод красники и лимонника можно считать ФПП, поскольку содержание в нем антоцианов составляет более $15 \%$ от суточной нормы потребления.

Органолептические и физико-химические показатели качества крема сливочного основного с добавлением концентрированного антоцианового красителя при температуре 4-6 ${ }^{\circ} \mathrm{C}$ существенно не изменялись в течение недели. Расслоения красителя и крема не наблюдалось. При комнатной температуре видимые изменения наблюдались после трех дней хранения крема. Коллоидное состояние крема сливочного основного не менялось, однако было заметно обесцвечивание образца крема, что свидетельствует о деградации антоцианов.

Таким образом, полученные данные показывают возможность использования концентрированного антоцианового красителя в технологии отделочных полуфабрикатов. Это позволяет повысить пищевую ценность сливочных кремов, обогатить их биологически активными соединениями, а также улучшить их цветовую гамму и значительно расширить сферу применения гидрофильных пигментов. 


\subsection{4. Использование антоцианов \\ в производстве мучных кондитерских изделий}

В данном разделе показана возможность использования экстракта антоцианов, сушеных ягод черной смородины и их выжимок в производстве мучных кондитерских изделий на примере бисквита круглого («Буше»).

Бисквит «Буше» готовили по стандартной технологии [16]. Технологическая схема приготовления выжимок из ягод черной смородины представлена на рисунке 4.6.

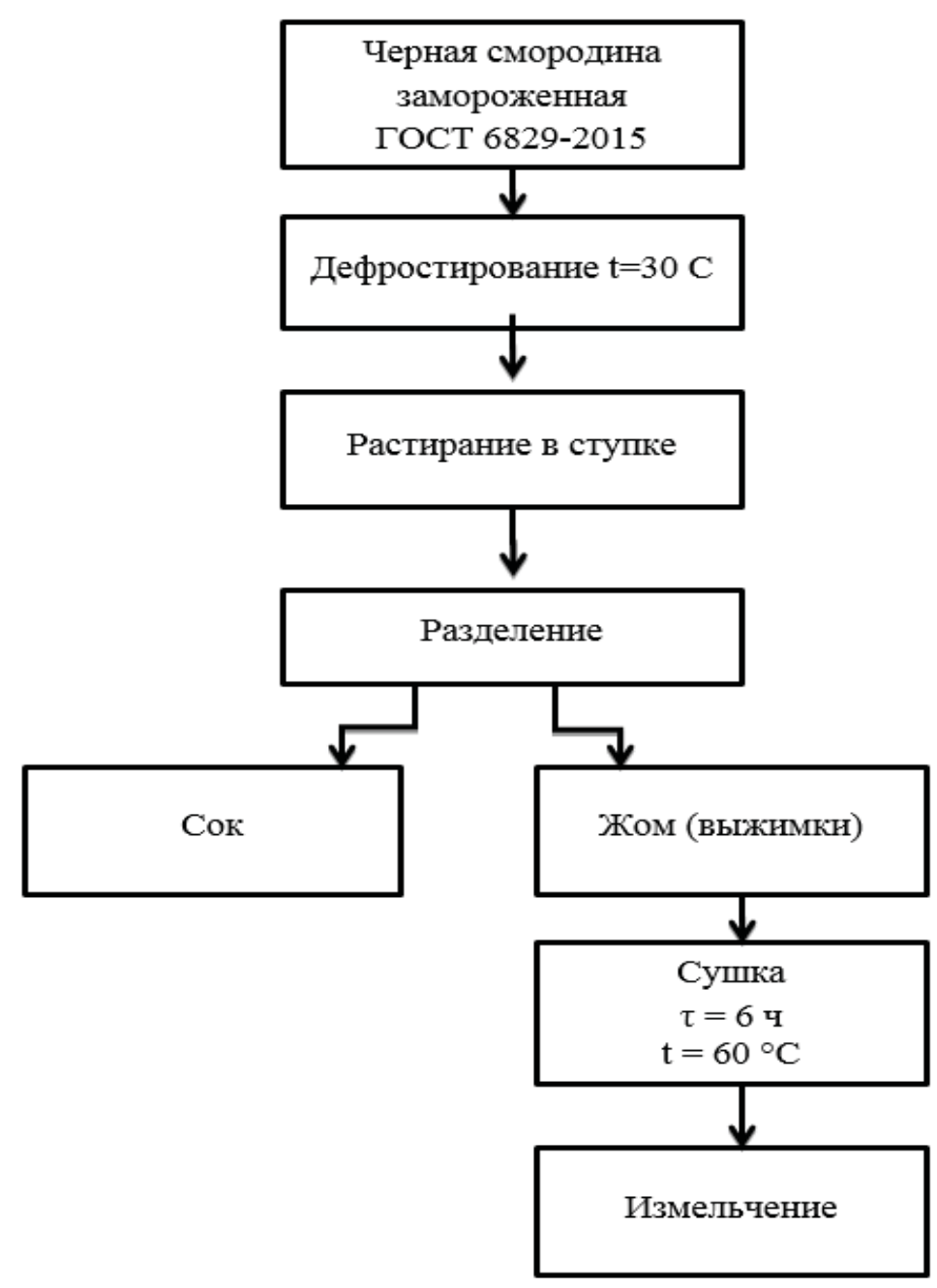

Рuc. 4.6. Технологическая схема приготовления выжимок из ягод черной смородины

Измельченные выжимки черной смордины добавляли во время взбивания белков в количестве 10, 20 и 30 \% к массе продукта. Тех- 
нологическая схема бисквита «Буше» с добавлением выжимок из ягод черной смородины представлены на рисунке 4.7.

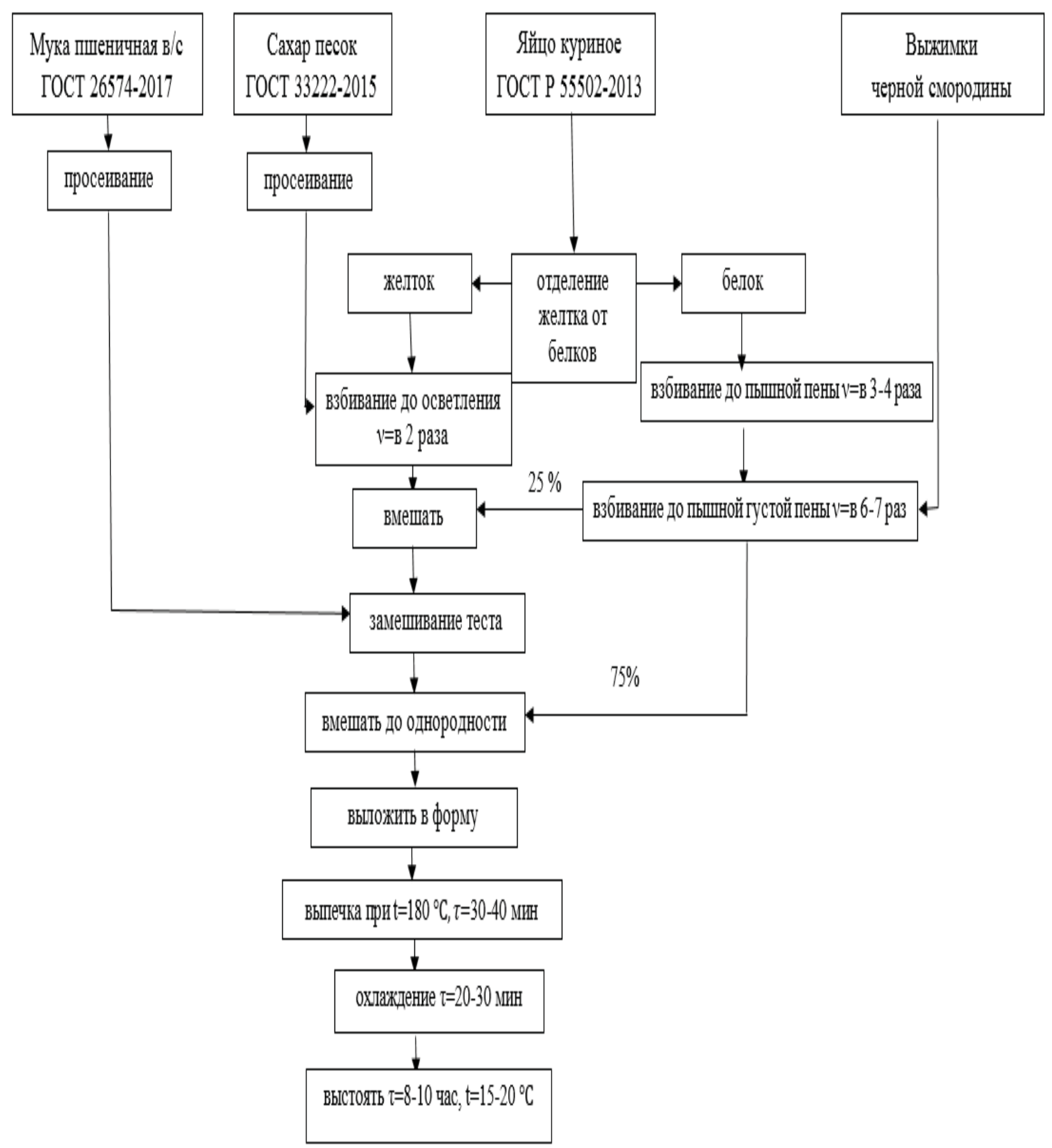

Puc. 4.7. Технологическая схема производства бисквита «Буше» с добавлением выжимок из ягод черной смородины

В зависимости от количества вносимых выжимок выпеченный бисквит имел различные оттенки сиреневого цвета, изменялся вкус и 
внешний вид изделия. Профилограмма бальной оценки образцов бисквита «Буше» с добавлением выжимок из ягод черной смородины представлена на рисунке 4.8 .

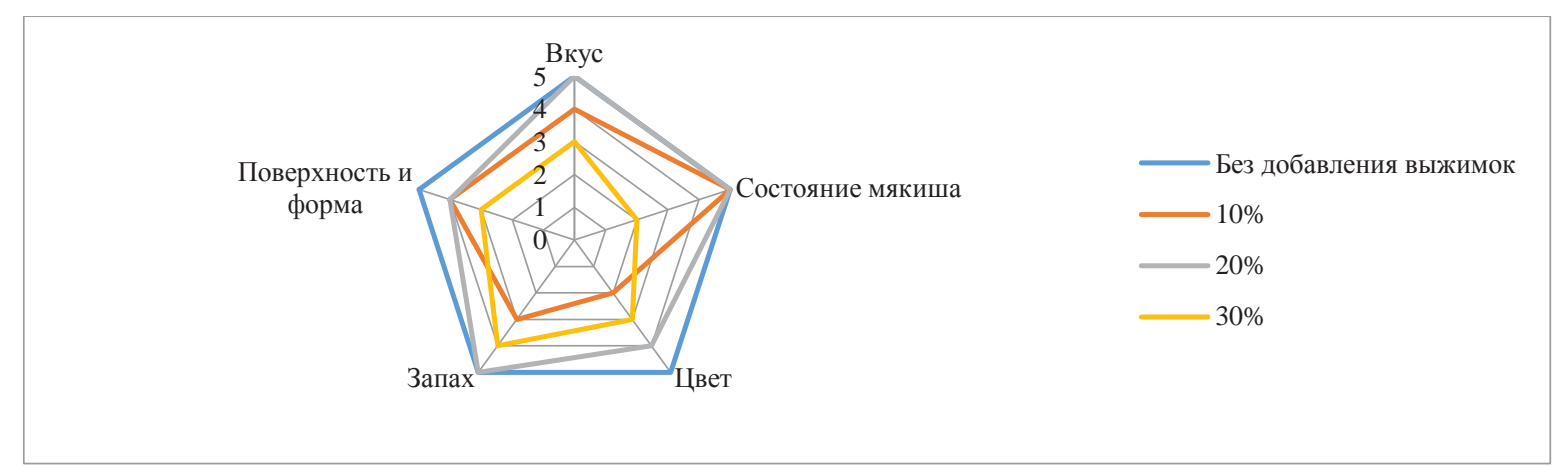

Puc. 4.8. Профилограмма бальной оценки органолептических показателей образцов бисквита «Буше» с добавлением выжимок из ягод черной смородины

Наилучшие органолептические показатели имел бисквит «Буше» с добавлением 20 \% выжимок черной смородины.

Раствор антоцианов в количестве 20, 30 и 40 \% добавляли в бисквит «Буше» также на стадии взбивания белков. При этом введение в бисквит «Буше» раствора антоцианов, имеющего довольно кислую $\mathrm{pH}$ среды $(\mathrm{pH}=2,5)$, позволяет исключить из рецептуры изделия лимонную кислоту.

Профилограмма бальной оценки образцов бисквита «Буше» с добавлением экстракта антоцианов представлена на рисунке 4.9.

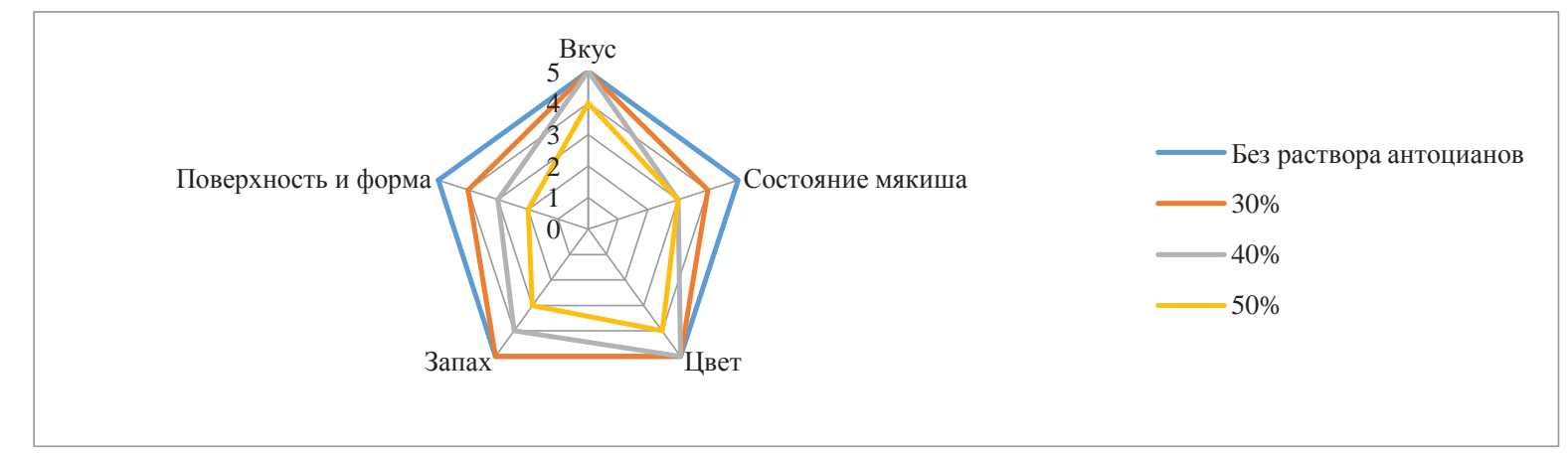

Puc. 4.9. Профилограмма бальной оценки органолептических показателей образцов бисквита «Буше» с добавлением экстракта антоцианов 
Наилучшие органолептические показатели имел бисквит «Буше» с добавлением 30 \% раствора антоцианов.

Сушеные измельченные ягоды черной смородины добавляли в количестве 5, 10 и 20 \% в бисквит «Буше», как и в предыдущих случаях, на стадии взбивания яичного белка. Профилограмма бальной оценки органолептических показателей образцов бисквита «Буше» с добавлением сушеных измельченных ягод черной смородины, представлена на рисунке 4.10 .

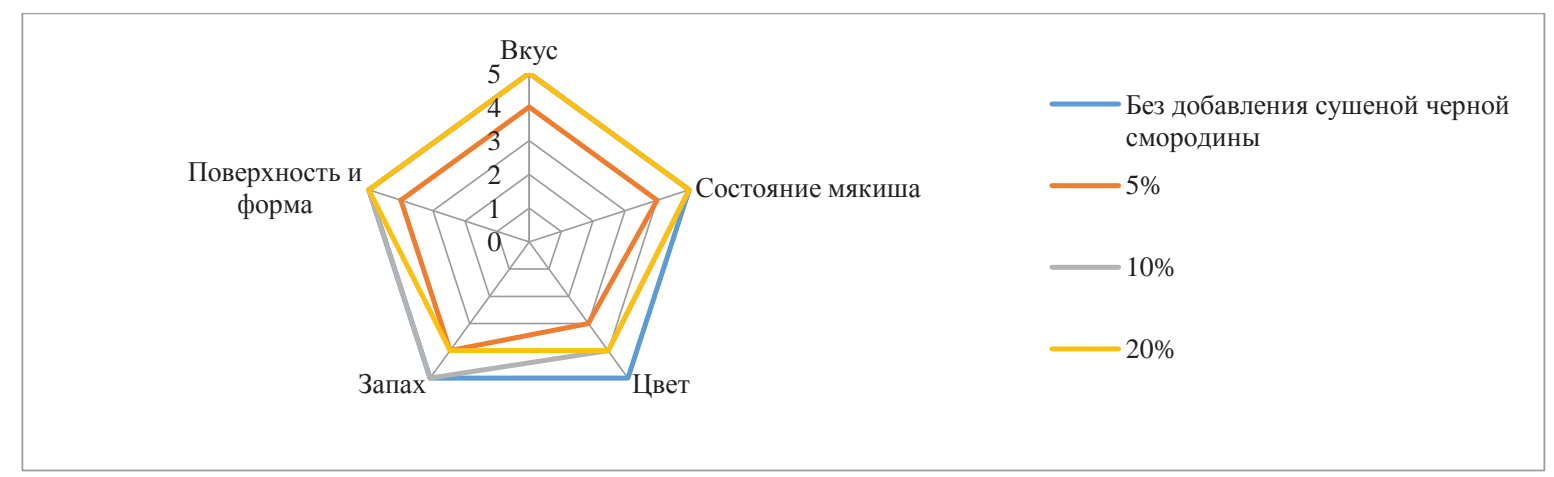

Puc. 4.10. Профилограмма бальной оценки

органолептических показателей образцов бисквита «Буше»

с добавлением сушеных измельченных ягод черной смородины

Наилучшие органолептические показатели имел бисквит «Буше» с добавлением 10 \% сушеных измельченных ягод черной смородины.

Органолептические показатели бисквита «Буше» с добавлением $20 \%$ выжимок, 30 \% раствора антоцианов и $10 \%$ сушенных измельченных ягод черной смородины представлены в таблице 4.18.

Из представленных результатов видно, что данное количество выжимок придавало бисквиту сиреневый цвет, приятный кислосладкий вкус и выраженный запах черной смородины. Кроме того, бисквит имел гладкую, без надрывов поверхность и пропеченный, не влажный на ощупь, однородный, мелкопористый мякиш.

Добавление 30 \% раствора антоцианов придавало бисквиту фиолетовый цвет, приятный кисло-сладкий вкус и выраженный запах черной смородины. Однако, из-за высокой влажности, бисквит имел деформированную с подрывами поверхность, влажный на ощупь, липкий, с неравномерной пористостью мякиш. 


\section{Органолептические показатели бисквитов «Буше»}

\section{с добавлением выжимок, раствора антоцианов}

\section{и сушенных измельченных ягод черной смородины}

\begin{tabular}{|c|c|c|c|c|}
\hline Показатели & $\begin{array}{c}\text { Бисквит } \\
\text { «Буше» без } \\
\text { добавления } \\
\text { антоцианов }\end{array}$ & $\begin{array}{c}\text { Бисквит } \\
\text { «Буше» с до- } \\
\text { бавлением } \\
20 \text { \% выжи- } \\
\text { мок из чер- } \\
\text { ной сморо- } \\
\text { дины } \\
\end{array}$ & $\begin{array}{c}\text { Бисквит «Буше» с } \\
\text { добавлением } 30 \text { \% } \\
\text { раствора антоциа- } \\
\text { нов }\end{array}$ & $\begin{array}{c}\text { Бисквит } \\
\text { «Буше» с до- } \\
\text { бавлением } \\
10 \% \text { суше- } \\
\text { ной черной } \\
\text { смородины }\end{array}$ \\
\hline $\begin{array}{l}\text { Состояние } \\
\text { мякиша }\end{array}$ & $\begin{array}{l}\text { Пористость } \\
\text { равномерная, } \\
\text { тонкостенная }\end{array}$ & $\begin{array}{l}\text { Пористость } \\
\text { равномерная, } \\
\text { тонкостен- } \\
\text { ная }\end{array}$ & $\begin{array}{l}\text { Плотный, пори- } \\
\text { стость неравно- } \\
\text { мерная, липкий }\end{array}$ & $\begin{array}{l}\text { Пористость } \\
\text { равномерная, } \\
\text { тонкостен- } \\
\text { ная }\end{array}$ \\
\hline Вкус & $\begin{array}{l}\text { Свойствен- } \\
\text { ный данному } \\
\text { виду изделия }\end{array}$ & $\begin{array}{l}\text { Сладкий, с } \\
\text { привкусом } \\
\text { черной смо- } \\
\text { родины }\end{array}$ & $\begin{array}{l}\text { Кисло-сладкий, с } \\
\text { привкусом черной } \\
\text { смородины }\end{array}$ & $\begin{array}{l}\text { Кисло- } \\
\text { сладкий, с } \\
\text { привкусом } \\
\text { черной смо- } \\
\text { родины } \\
\end{array}$ \\
\hline $\begin{array}{l}\text { Цвет мяки- } \\
\text { ша }\end{array}$ & $\begin{array}{l}\text { Белый с жел- } \\
\text { товатым от- } \\
\text { тенком }\end{array}$ & Сиреневый & Фиолетовый & Бордовый \\
\hline Запах & $\begin{array}{l}\text { Свойствен- } \\
\text { ный данному } \\
\text { виду изделия }\end{array}$ & $\begin{array}{l}\text { Выраженный } \\
\text { запах биск- } \\
\text { вита и чер- } \\
\text { ной сморо- } \\
\text { дины } \\
\end{array}$ & $\begin{array}{l}\text { Выраженный за- } \\
\text { пах бисквита и } \\
\text { черной смороди- } \\
\text { ны }\end{array}$ & $\begin{array}{l}\text { Выраженный } \\
\text { запах биск- } \\
\text { вита и чер- } \\
\text { ной сморо- } \\
\text { дины }\end{array}$ \\
\hline $\begin{array}{l}\text { Поверх- } \\
\text { ность и } \\
\text { форма } \\
\end{array}$ & $\begin{array}{l}\text { Гладкая без } \\
\text { подрывов и } \\
\text { трещин } \\
\end{array}$ & $\begin{array}{l}\text { Гладкая без } \\
\text { подрывов и } \\
\text { трещин } \\
\end{array}$ & $\begin{array}{l}\text { Деформирован- } \\
\text { ная, с подрывами }\end{array}$ & $\begin{array}{l}\text { Гладкая без } \\
\text { подрывов и } \\
\text { трещин }\end{array}$ \\
\hline
\end{tabular}

Добавление 10 \% сушеных измельченных ягод черной смородины придавало бисквиту бордовый цвет, приятный кисло-сладкий вкус и выраженный запах черной смородины. Кроме того, бисквит имел гладкую без подрывов поверхность. Мякиш пропеченный, не влажный на ощупь, с равномерной, тонкостенной пористостью и вкраплениями измельченных ягод.

Таким образом, использование раствора антоцианов, сушеных измельченных ягод черной смородины, а также ее выжимок в производ- 
стве бисквита «Буше» позволяет улучшать органолептические показатели, придавая изделию насыщенных цвет, кисло-сладкий вкус и выраженный ягодный запах. Кроме того, использование отходов сокового производства в технологии мучных кондитерских изделий позволяет повысить их пищевую ценность как за счет, содержащихся в выжимках антоцианов так и входящих в их состав пищевых волокон.

\subsection{5. Оценка качества и безопасности функциональных кондитерских изделий}

Основные физико-химические, а также санитарно-гигиенические показатели, определяющие качество разработанных функциональных продуктов, приведены в таблицах 4.19-4.25.

Таблица 4.19

\section{Физико-химические показатели качества мармелада, содержащего 26 \% комплекса}

\begin{tabular}{|c|c|c|c|c|c|}
\hline \multirow[t]{2}{*}{$\begin{array}{c}\text { Наименова- } \\
\text { ние показа- } \\
\text { телей, еди- } \\
\text { ницы изме- } \\
\text { рений }\end{array}$} & $\begin{array}{c}\text { Мармелад } \\
\text { с добавле- } \\
\text { ни-ем ком- } \\
\text { плекса, со- } \\
\text { держащего } \\
\text { антоцианы } \\
\text { лимонника }\end{array}$ & $\begin{array}{c}\text { Мармелад } \\
\text { с добавле- } \\
\text { ни-ем ком- } \\
\text { плекса, со- } \\
\text { держащего } \\
\text { антоцианы } \\
\text { калины }\end{array}$ & \multirow[t]{2}{*}{$\begin{array}{c}\text { Погреш- } \\
\text { ность из- } \\
\text { мерений } \\
\text { при } \mathrm{P}=0,95\end{array}$} & \multirow[t]{2}{*}{$\begin{array}{c}\text { Норматив- } \\
\text { ное значе- } \\
\text { ние } \\
\text { ГОСТ } \\
6442-2014\end{array}$} & \multirow[t]{2}{*}{$\begin{array}{c}\text { НД на } \\
\text { методы } \\
\text { испыта- } \\
\text { ний }\end{array}$} \\
\hline & \multicolumn{2}{|c|}{ Фактическое значение } & & & \\
\hline $\begin{array}{l}\text { Массовая } \\
\text { доля влаги, } \\
\%\end{array}$ & 23,5 & 22,7 & $\pm 0,4$ & $15-24$ & $\begin{array}{l}\text { ГОСТ } \\
5900- \\
2014\end{array}$ \\
\hline $\begin{array}{l}\text { Массовая } \\
\text { доля общей } \\
\text { золы нерас- } \\
\text { творимой в } \\
\text { 10\%-ном } \\
\text { растворе со- } \\
\text { ляной кисло- } \\
\text { ты, не более, } \\
\%\end{array}$ & 0,022 & 0,021 & $\pm 0,009$ & 0,05 & $\begin{array}{l}\text { ГОСТ } \\
5901- \\
2014\end{array}$ \\
\hline
\end{tabular}


Окончание табл. 4.19

\begin{tabular}{|l|l|l|l|l|l|}
\hline $\begin{array}{l}\text { Общая кис- } \\
\text { лотность, град }\end{array}$ & 19,0 & 7,0 & $\pm 0,3$ & - & $\begin{array}{l}\text { ГОСТ } \\
5898-87\end{array}$ \\
\hline $\begin{array}{l}\text { Массовая доля } \\
\text { угеводов, \% }\end{array}$ & 67,1 & 67,5 & & - & расчетный \\
\hline $\begin{array}{l}\text { Массовая доля } \\
\text { редуцирующих } \\
\text { веществ, \% }\end{array}$ & 8,9 & 6,7 & $\pm 1,0$ & - & $\begin{array}{l}\text { ГОСТ } \\
5903-89\end{array}$ \\
\hline
\end{tabular}

Таблица 4.20

Санитарно-гигиенические показатели качества мармелада, содержащего 26 \% комплекса

\begin{tabular}{|c|c|c|c|c|c|c|}
\hline \multirow{2}{*}{$\begin{array}{c}\text { Наимено- } \\
\text { ва-ние по- } \\
\text { казателей, } \\
\text { единицы } \\
\text { измерений }\end{array}$} & \multicolumn{2}{|c|}{$\begin{array}{l}\text { Мармелад с добав- } \\
\text { лением комплекса, } \\
\text { содержащего анто- } \\
\text { цианы лимонника }\end{array}$} & \multicolumn{2}{|c|}{$\begin{array}{c}\text { Мармелад с добавле- } \\
\text { нием комплекса, со- } \\
\text { держащего антоциа- } \\
\text { ны калины }\end{array}$} & \multirow{2}{*}{$\begin{array}{c}\text { Погре- } \\
\text { шность } \\
\text { измере- } \\
\text { ний при } \\
\mathrm{P}=0,95\end{array}$} & \multirow[t]{2}{*}{$\begin{array}{c}\text { НД на } \\
\text { методы } \\
\text { испы- } \\
\text { таний }\end{array}$} \\
\hline & $\begin{array}{c}\text { Норма- } \\
\text { тивное } \\
\text { значе- } \\
\text { ние, } \\
\text { не более }\end{array}$ & $\begin{array}{l}\text { Фактиче- } \\
\text { ское зна- } \\
\text { чение }\end{array}$ & $\begin{array}{c}\text { Норма- } \\
\text { тив-ное } \\
\text { значение, } \\
\text { не более }\end{array}$ & $\begin{array}{c}\text { Фактиче- } \\
\text { ское зна- } \\
\text { чение }\end{array}$ & & \\
\hline $\begin{array}{l}\text { Патоген- } \\
\text { ные, в том } \\
\text { числе } \\
\text { сальмо- } \\
\text { неллы, в } \\
25 \text { г }\end{array}$ & $\begin{array}{l}\text { Не до- } \\
\text { пускает- } \\
\text { ся }\end{array}$ & $\begin{array}{l}\text { Отсут- } \\
\text { ству-ет }\end{array}$ & $\begin{array}{l}\text { Не до- } \\
\text { пускает- } \\
\text { ся }\end{array}$ & $\begin{array}{l}\text { Отсутст- } \\
\text { вует }\end{array}$ & - & $\begin{array}{l}\text { ГОСТ } \\
31659- \\
2012\end{array}$ \\
\hline $\begin{array}{l}\text { КМАФА- } \\
\text { иМ, КОЕ/Г }\end{array}$ & $\begin{array}{l}\text { Не бо- } \\
\text { лее } \\
1 \times 10^{3}\end{array}$ & $1 \times 10^{2}$ & $\begin{array}{l}\text { Не более } \\
1 \times 10^{3}\end{array}$ & $1 \times 10^{2}$ & - & $\begin{array}{l}\text { ГОСТ } \\
10444 . \\
15-94\end{array}$ \\
\hline $\begin{array}{l}\text { БГКП } \\
\text { (колифор- } \\
\text { мы), в 0,1г }\end{array}$ & $\begin{array}{l}\text { Не до- } \\
\text { пускает- } \\
\text { ся } \\
\end{array}$ & $\begin{array}{l}\text { Отсутст- } \\
\text { вует }\end{array}$ & $\begin{array}{l}\text { Не до- } \\
\text { пускает- } \\
\text { ся }\end{array}$ & $\begin{array}{l}\text { Отсутст- } \\
\text { вует }\end{array}$ & - & $\begin{array}{l}\text { ГОСТ } \\
31747- \\
2012\end{array}$ \\
\hline $\begin{array}{l}\text { Плесени } \\
\text { КОЕ/Г }\end{array}$ & $\begin{array}{l}\text { Не бо- } \\
\text { лее } 100\end{array}$ & Менее 10 & $\begin{array}{l}\text { Не более } \\
100\end{array}$ & Менее 10 & - & $\begin{array}{l}\text { ГОСТ } \\
10444 . \\
12- \\
2013\end{array}$ \\
\hline
\end{tabular}


Окончание табл. 4.20

\begin{tabular}{|l|l|l|l|l|l|l|}
\hline $\begin{array}{l}\text { Дрожжи, } \\
\text { КОЕ/ }\end{array}$ & $\begin{array}{l}\text { Не бо- } \\
\text { лее 50 }\end{array}$ & Менее 10 & $\begin{array}{l}\text { Не более } \\
50\end{array}$ & Менее 10 & - & \\
\hline $\begin{array}{l}\text { Свинец, } \\
\text { мг/кг }\end{array}$ & 1,0 & 0,094 & 1,0 & 0,046 & $\pm 0,016$ & $\begin{array}{l}\text { ГОСТ } \\
33824- \\
2016\end{array}$ \\
\hline $\begin{array}{l}\text { Мышьяк, } \\
\text { мг/кг }\end{array}$ & 1,0 & 0,025 & 1,0 & $<0,02$ & - & $\begin{array}{l}\text { ГОСТ } \\
31628- \\
2012\end{array}$ \\
\hline $\begin{array}{l}\text { Кадмий, } \\
\text { мг/кг }\end{array}$ & 0,1 & 0,008 & 0,1 & 0,032 & $\pm 0,010$ & $\begin{array}{l}\text { ГОСТ } \\
33824- \\
2016\end{array}$ \\
\hline $\begin{array}{l}\text { Ртуть, } \\
\text { мг/кг }\end{array}$ & 0,01 & $<0,005$ & 0,01 & $<0,005$ & - & $\begin{array}{l}\text { МУ } \\
5178- \\
90\end{array}$ \\
\hline
\end{tabular}

Таблищуа 4.21

Физико-химические показатели зефира с добавлением 13 \% комплекса желатина и антоцианов черной смородины

\begin{tabular}{|l|l|l|}
\hline \multicolumn{1}{|c|}{ Наименование показателя } & $\begin{array}{l}\text { Нормативный } \\
\text { показатель }\end{array}$ & $\begin{array}{c}\text { Зефир с добавлением ком- } \\
\text { плекса }\end{array}$ \\
\hline Массовая доля влаги, \% & не более 25 & 9,9 \\
\hline $\begin{array}{l}\text { Массовая доля золы, не раство- } \\
\text { римой в растворе соляной кисло- } \\
\text { ты с массовой долей } 10 \%, \%\end{array}$ & не более 0,05 & $0,039 \pm 0,007$ \\
\hline $\begin{array}{l}\text { Массовая доля общей сернистой } \\
\text { кислоты, \% }\end{array}$ & не более 0,01 & $0,0065 \pm 0,0012$ \\
\hline
\end{tabular}

Таблищуа 4.22

Физико-химические, микробиологические показатели

и показатели безопасности зефира с добавлением антоцианового красителя, содержащего комплекс антоцианов и яичного альбумина

\begin{tabular}{|l|l|l|}
\hline \multicolumn{1}{|c|}{$\begin{array}{c}\text { Наименование } \\
\text { показателя }\end{array}$} & $\begin{array}{c}\text { Норматив- } \\
\text { ный показа- } \\
\text { тель }\end{array}$ & $\begin{array}{c}\text { Зефир с добавление комплекса ан- } \\
\text { тоцианов черной смородины и яич- } \\
\text { ного альбумина }\end{array}$ \\
\hline & \multicolumn{2}{|c|}{ Физико-химические показатели } \\
\hline Массовая доля влаги, \% & - & \multicolumn{2}{c|}{$16,6 \pm 0,4$} \\
\hline $\begin{array}{l}\text { Массовая доля золы, не } \\
\text { растворимой в растворе } \\
\text { соляной кислоты с мас- } \\
\text { совой долей } 10 \%, \%\end{array}$ & $0,081 \pm 0,007$ \\
\hline
\end{tabular}


Окончание табл. 4.22

\begin{tabular}{|l|c|c|}
\hline $\begin{array}{l}\text { Массовая доля общей } \\
\text { сернистой кислоты, } \%\end{array}$ & $-2,010 \pm 0,001$ \\
\hline \multicolumn{1}{|c|}{ Показатели безопасности } \\
\hline $\begin{array}{c}\text { Токсичные элементы. } \\
\text { мг/кг }\end{array}$ & \multicolumn{2}{|c|}{} \\
\hline Свинец & 1,0 & $<0,04$ \\
\hline Мышьяк & \multicolumn{2}{|c|}{ Микробиологические показатели } \\
\hline \multicolumn{2}{|c|}{$\begin{array}{c}\text { Патогенные, в том чис- } \\
\text { ле сальмонеллы, в 25 г }\end{array}$} & не доп. \\
\hline КМАФАнМ, КОЕ/Г & не более \\
$1 \times 10^{3}$ & $<100$ \\
\hline $\begin{array}{l}\text { БГКП (колиформы), в } \\
1,0 \text { г }\end{array}$ & не доп. \\
\hline Плесени, КОЕ/г & не более 100 & отс. \\
\hline Дрожжи, КОЕ/г & не более 50 & $<10$ \\
\hline
\end{tabular}

Таблица 4.23

Физико-химические, микробиологические,

а также показатели безопасности крема с добавлением 15 мас. \% окрашенного структурообразователя

\begin{tabular}{|c|c|c|}
\hline $\begin{array}{c}\text { Наименование показателей, } \\
\text { единицы измерений }\end{array}$ & $\begin{array}{c}\text { Крем, с добавлением } \\
15 \text { мас. \% окрашенно- } \\
\text { го структуро- } \\
\text { образователя }\end{array}$ & $\begin{array}{c}\text { НД на методы } \\
\text { испытаний }\end{array}$ \\
\hline \multicolumn{3}{|c|}{ Физико-химические показатели } \\
\hline $\begin{array}{l}\text { Массовая доля общего сахара } \\
\text { в пересчете на сухое вещество, } \\
\%\end{array}$ & 42,6 & ГОСТ 5903-89 \\
\hline Массовая доля влаги, \% & 15,3 & ГОСТ 5900-2014 \\
\hline $\begin{array}{l}\text { Массовая доля жира в пере- } \\
\text { счете на сухое вещество, \% }\end{array}$ & 48,4 & ГОСТ 5867-90 \\
\hline \multicolumn{3}{|c|}{ Микробиологические показатели } \\
\hline $\begin{array}{l}\text { Патогенные, в том числе } \\
\text { сальмонеллы, в } 25 \text { г }\end{array}$ & $1,4^{\times} \times 10^{4}$ & ГОСТ 31659-2012 \\
\hline КМАФАнМ, КОЕ/Г & Не обнаружен & ГОСТ10444. 15-94 \\
\hline БГКП (колиформы), в 1,0 г & Не обнаружен & ГОСТ 31747-2012 \\
\hline
\end{tabular}


Окончание табл. 4.23

\begin{tabular}{|l|l|l|}
\hline Плесени, КОЕ/Г & $<10$ & ГОСТ 10444. 12-2013 \\
\hline Дрожжи, КОЕ/Г & $<10$ & ГОСТ 10444. 12-2013 \\
\hline Staphylососсиз aureus в 0,1 г & Не обнаружен & ГОСТ 31746-2012 \\
\hline \multicolumn{2}{|c|}{ Показатели безопасности } \\
\hline Свинец, мг/кг & 0,041 & ГОСТ 33824-2016 \\
\hline Мышьяк, мг/кг & 0,025 & ГОСТ 31628-2012 \\
\hline Кадмий, мг/кг & 0,007 & ГОСТ 33824-2016 \\
\hline Ртуть, мг/кг & $<0,005$ & МУ 5178-90 \\
\hline
\end{tabular}

Таблица 4.24

Физико-химические, микробиологические,

а также показатели безопасности крема с добавлением 15 мас. \% концентрированного антоцианового красителя красники

\begin{tabular}{|l|l|l|}
\hline $\begin{array}{c}\text { Наименование пока- } \\
\text { зателей, единицы } \\
\text { измерений }\end{array}$ & $\begin{array}{c}\text { Крем, с добавлением } \\
15 \text { мас. \% концентри- } \\
\text { рованного антоциано- } \\
\text { вого красителя }\end{array}$ & НД на методы испытаний \\
\hline \multicolumn{2}{|c|}{ Физико-химические показатели } \\
\hline $\begin{array}{l}\text { Массовая доля обще- } \\
\text { го сахара в пересчете } \\
\text { на сухое вещество, \% }\end{array}$ & 39,8 & ГОСТ 5903-89 \\
\hline $\begin{array}{l}\text { Массовая доля влаги, } \\
\%\end{array}$ & 10,5 & ГОСТ 5900-2014 \\
\hline $\begin{array}{l}\text { Массовая доля жира } \\
\text { в пересчете на сухое } \\
\text { вещество, \% }\end{array}$ & 52,2 & ГОСТ 5867-90 \\
\hline \multicolumn{2}{|l|}{ Микробиологические показатели } \\
\hline $\begin{array}{l}\text { Патогенные, в том } \\
\text { числе сальмонеллы, } \\
\text { в 25 г }\end{array}$ & $4,2 \times 10^{3}$ & ГОСТ 31659-2012 \\
\hline КМАФАнМ, КОЕ/Г & Не обнаружен & ГОСТ10444. 15-94 \\
\hline $\begin{array}{l}\text { БГКП (колиформы), } \\
\text { в 1,0 г }\end{array}$ & Не обнаружен & ГОСТ 31747-2012 \\
\hline Плесени, КОЕ/Г & $<10$ & ГОСТ 10444. 12-2013 \\
\hline Дрожжи, КОЕ/г & $<10$ & ГОСТ 10444. 12-2013 \\
\hline
\end{tabular}


Окончание табл. 4.24

\begin{tabular}{|l|l|l|}
\hline $\begin{array}{l}\text { Staphyloсоссиs } \\
\text { aureus в } 0,1 \text { г }\end{array}$ & Не обнаружен & ГОСТ 31746-2012 \\
\hline \multicolumn{2}{|c|}{ Показатели безопасности } \\
\hline Свинец, мг/кг & 0,039 & ГОСТ 33824-2016 \\
\hline Мышьяк, мг/кг & 0,015 & ГОСТ 31628-2012 \\
\hline Кадмий, мг/кг & 0,009 & ГОСТ 33824-2016 \\
\hline Ртуть, мг/кг & $<0,003$ & МУ 5178-90 \\
\hline
\end{tabular}

Таблица 4.25

\section{Физико-химические, микробиологические}

и показатели безопасности бисквитов «Буше»

с добавлением выжимок, экстракта антоцианов

и сушенных измельченных ягод черной смородины

\begin{tabular}{|c|c|c|c|c|c|}
\hline $\begin{array}{c}\text { Наименова- } \\
\text { ние показа- } \\
\text { телей }\end{array}$ & $\begin{array}{c}\text { Норма- } \\
\text { тивное } \\
\text { значе- } \\
\text { ние }\end{array}$ & $\begin{array}{c}\text { Бисквит } \\
\text { «Буше» с до- } \\
\text { бавлением } \\
\text { 20\% выжи- } \\
\text { мок из чер- } \\
\text { ной сморо- } \\
\text { дины }\end{array}$ & $\begin{array}{c}\text { Бисквит } \\
\text { «Буше» с до- } \\
\text { бавлением } \\
30 \% \text { раство- } \\
\text { ра антоциа- } \\
\text { нов }\end{array}$ & $\begin{array}{c}\text { Бисквит } \\
\text { «Буше» с } \\
\text { добавле- } \\
\text { нием } 10 \% \\
\text { сушеной } \\
\text { черной } \\
\text { смороди- } \\
\text { ны }\end{array}$ & $\begin{array}{c}\text { НД на } \\
\text { методы } \\
\text { испыта- } \\
\text { ний }\end{array}$ \\
\hline \multicolumn{6}{|c|}{ Физико-химические показатели } \\
\hline $\begin{array}{l}\text { Массовая } \\
\text { доля влаги, } \\
\%\end{array}$ & - & $24,5 \pm 0,4$ & $47,3 \pm 0,4$ & $26,5 \pm 0,4$ & $\begin{array}{l}\text { ГОСТ } \\
5900- \\
2014\end{array}$ \\
\hline $\begin{array}{l}\text { Пористость } \\
\text { мякиша, \% }\end{array}$ & - & $76,4 \pm 0,6$ & $56,8 \pm 0,6$ & $73,7 \pm 0,7$ & $\begin{array}{l}\text { ГОСТ } \\
5669-96 \\
\end{array}$ \\
\hline $\begin{array}{l}\text { Кислотность, } \\
\text { град }\end{array}$ & - & $0,8 \pm 1,0$ & $3,0 \pm 1,0$ & $0,7 \pm 1,0$ & $\begin{array}{l}\text { ГОСТ } \\
5670-96\end{array}$ \\
\hline $\begin{array}{l}\text { Массовая } \\
\text { доля сахара } \\
\text { (по сахарозе) } \\
\text { в пересчете } \\
\text { на сухое ве- } \\
\text { щество, \% }\end{array}$ & - & $34,3 \pm 0,3$ & $49,9 \pm 0,3$ & $45,1 \pm 0,3$ & $\begin{array}{l}\text { ГОСТ } \\
5903-89\end{array}$ \\
\hline
\end{tabular}


Окончание табл. 4.25

\begin{tabular}{|c|c|c|c|c|c|}
\hline $\begin{array}{l}\text { Массовая } \\
\text { доля золы, } \\
\text { нераствори- } \\
\text { мой в 10\% } \\
\text { растворе со- } \\
\text { ляной кисло- } \\
\text { ты, \% }\end{array}$ & - & $0,086 \pm 0,07$ & $0,054 \pm 0,07$ & $0,079 \pm 0,07$ & \begin{tabular}{l|l}
7 & ГОСТ \\
$5901-$ \\
2014
\end{tabular} \\
\hline \multicolumn{6}{|c|}{ Микробиологические показатели } \\
\hline $\begin{array}{l}\text { Патогенные, } \\
\text { в том числе } \\
\text { сальмонел- } \\
\text { лы, в } 25 \text { г } \\
\end{array}$ & не доп. & $\begin{array}{l}\text { не обнару- } \\
\text { жено }\end{array}$ & $\begin{array}{l}\text { не обнару- } \\
\text { жено }\end{array}$ & $\begin{array}{l}\text { не обна- } \\
\text { ружено }\end{array}$ & $\begin{array}{l}\text { ГОСТ } \\
31659- \\
2012\end{array}$ \\
\hline $\begin{array}{l}\text { КМАФАнМ, } \\
\text { КОЕ/Г }\end{array}$ & $\begin{array}{l}\text { не более } \\
5 \times 10^{3}\end{array}$ & $1,25 \times 10^{2}$ & $1,5 \times 10^{2}$ & $1,0 \times 10^{2}$ & $\begin{array}{l}\text { ГОСТ } \\
10444 . \\
15-94\end{array}$ \\
\hline $\begin{array}{l}\text { БГКП (коли- } \\
\text { формы), в 1,0 } \\
\text { Г }\end{array}$ & не доп. & $\begin{array}{l}\text { не } \\
\text { обнаружено }\end{array}$ & $\begin{array}{l}\text { не обнару- } \\
\text { жено }\end{array}$ & $\begin{array}{l}\text { не обна- } \\
\text { ружено }\end{array}$ & $\begin{array}{l}\text { ГOCT } \\
31747- \\
2012\end{array}$ \\
\hline $\begin{array}{l}\text { Плесени, } \\
\text { КОЕ/Г }\end{array}$ & $\begin{array}{l}\text { не более } \\
100 \\
\end{array}$ & $<10$ & $<10$ & $<10$ & \multirow{2}{*}{$\begin{array}{l}\text { ГОСТ } \\
10444 . \\
12-2013\end{array}$} \\
\hline $\begin{array}{l}\text { Дрожжи, } \\
\text { КОЕ/г }\end{array}$ & $\begin{array}{l}\text { не более } \\
50 \\
\end{array}$ & $<10$ & $<10$ & $<10$ & \\
\hline \multicolumn{6}{|c|}{ Показатели безопасности } \\
\hline $\begin{array}{l}\text { Свинец, } \\
\text { мг/кг }\end{array}$ & $\begin{array}{l}\text { не более } \\
0,5\end{array}$ & 0,05 & 0,04 & 0,05 & $\begin{array}{l}\text { ГОСТ } \\
\text { 33824-2016 } \\
\end{array}$ \\
\hline $\begin{array}{l}\text { Мышьяк, } \\
\text { мг/кг }\end{array}$ & $\begin{array}{l}\text { не более } \\
0,3\end{array}$ & 0,02 & 0,01 & 0,01 & \begin{tabular}{|l|} 
ГОСТ \\
31628-2012 \\
\end{tabular} \\
\hline $\begin{array}{l}\text { Кадмий, } \\
\text { мг/кг }\end{array}$ & $\begin{array}{l}\text { не более } \\
0,1\end{array}$ & 0,01 & 0,009 & 0,011 & \begin{tabular}{|l|} 
ГОСТ \\
$33824-2016$ \\
\end{tabular} \\
\hline $\begin{array}{l}\text { Ртуть, } \\
\text { мг/кг }\end{array}$ & \begin{tabular}{|l|} 
не более \\
0,02
\end{tabular} & $<0,004$ & $<0,003$ & $<0,002$ & МУ 5178-90 \\
\hline
\end{tabular}

Полученные данные показали, что физико-химические показатели качества разработанных функциональных продуктов не превышают допустимые нормативные значения. Санитарно-гигиенические показатели качества функциональных кондитерских изделий находятся в пределах допустимых значений и соответствуют Техническому регламенту Таможенного союза ТР ТС 021/2012 «О безопасности пищевой продукции» [19]. 


\section{2. Использование антоцианов}

\section{для создания смарт упаковки}

Растущая озабоченность по поводу окружающей среды и безопасности пластиковой упаковки, стимулировала исследователей на создание биоразлагаемых и съедобных пленок для упаковки пищевых продуктов [33, 73]. Смарт упаковка - это система, которая может контролировать качество и продление сроков годности пищевых продуктов, а также условия хранения упакованных пищевых продуктов и предоставлять потребителям информацию об их порче в цепочке их поставок [58, 80].

В последние годы все большее внимание уделяется разработке смарт упаковки на основе биополимеров и антоцианов. Данный тип упаковки позволяет информировать потребителей о качестве продуктов в режиме реального времени, а также пролонгировать сроки годности изделий [68].

В данной главе показана возможность создания пленок на основе полисахаридов, с добавлением антоцианов и использование их в качестве смарт упаковки для анализа качества рыбного сырья.

Полученный из ягод черной смородины экстракт антоцианов использовали для создания пищевых пленок. Пленку получали, нагревая водный экстракт антоцианов со структурообразователем при температуре $100{ }^{\circ} \mathrm{C}$ в течение 3 мин, после чего раствор охлаждали до $60{ }^{\circ} \mathrm{C}$, разливали в формы и оставляли на 8 ч при комнатной температуре для созревания или высушивали 1 ч при температуре $60{ }^{\circ} \mathrm{C}$. Технологическая схема приготовления пленки с добавлением экстракта антоцианов черной смородины представлена на рисунке 4.11.

В качестве основы для создания пленок использовались анионные (агар-агар, каппа-каррагинан), нейтральный (крахмал) и катионный (хитозан) полисахариды. Было разработано 11 образцов пленок. Характеристика образцов пленок, полученных на основе агар-агара, каппа-каррагинана, крахмала и хитозана с добавлением антоцианов представлена в таблице 4.26. 


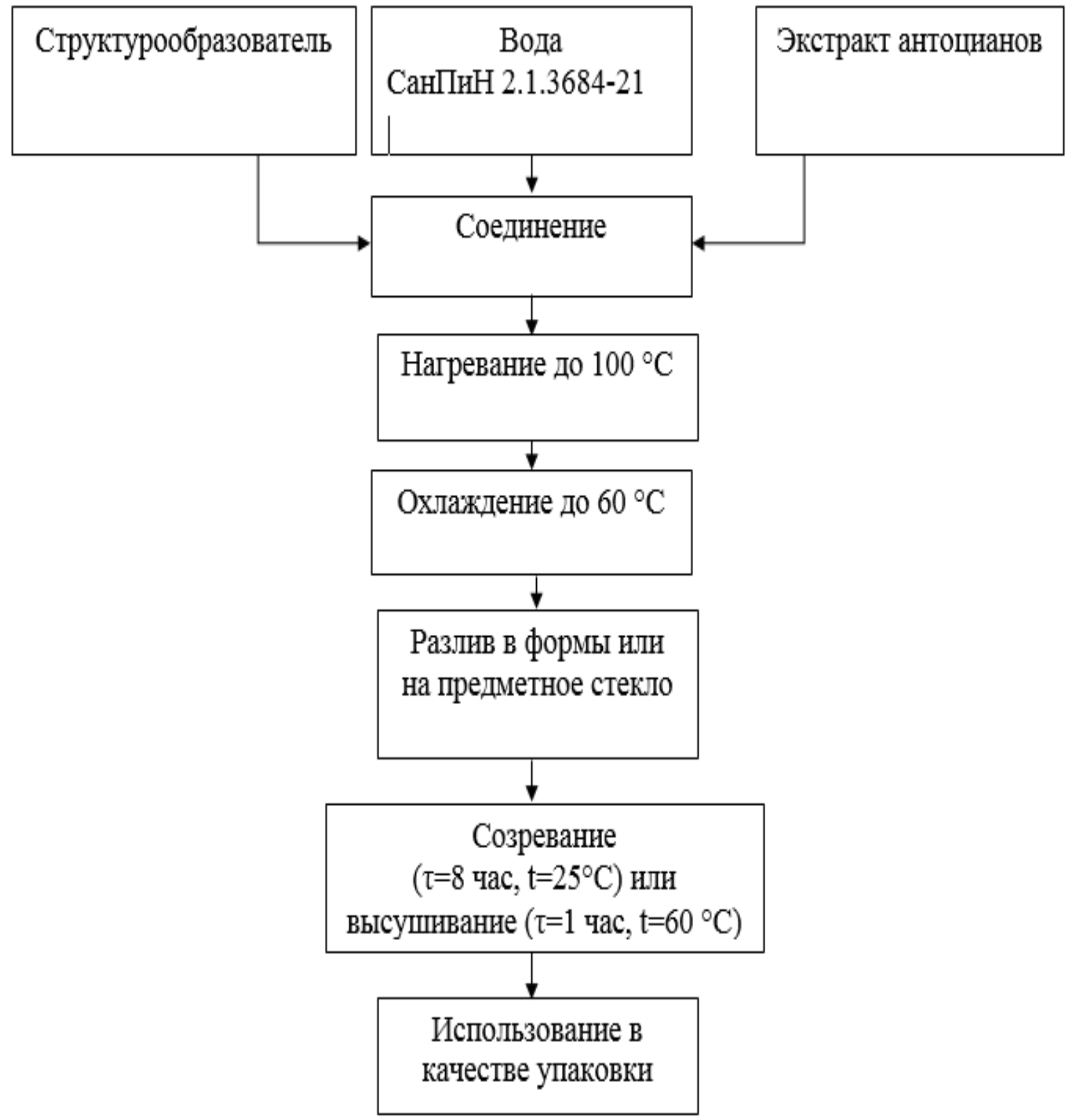

Puc. 4.11. Технологическая схема приготовления пленки с добавлением 50 \% экстракта антоцианов черной смородины 


\section{Характеристика образцов пленок на основе полисахаридов с добавлением антоцианов}

\begin{tabular}{|c|c|c|}
\hline $\begin{array}{l}\text { № об- } \\
\text { разца }\end{array}$ & $\begin{array}{c}\text { Количество } \\
\text { структурообразователя, } \\
\%\end{array}$ & Характеристика плёнок \\
\hline \multicolumn{3}{|c|}{ Azар-агар } \\
\hline 1 & 1,0 & $\begin{array}{l}\text { Ярко красного цвета, нестойкая, легко } \\
\text { разрушается }\end{array}$ \\
\hline 2 & 1,5 & $\begin{array}{l}\text { Ярко-красного цвета, упругая, недоста- } \\
\text { точно стойкая к деформации }\end{array}$ \\
\hline 3 & 2,0 & $\begin{array}{l}\text { Ярко-красного цвета, достаточно плотная, } \\
\text { при деформации образуются трещины }\end{array}$ \\
\hline \multicolumn{3}{|c|}{ Каппа-каррагинан } \\
\hline 4 & 1,0 & $\begin{array}{l}\text { Ярко-красного цвета, жидкой } \\
\text { консистенции }\end{array}$ \\
\hline 5 & 1,5 & Ярко-красного цвета, легко разрывается \\
\hline 6 & 2,0 & $\begin{array}{l}\text { Ярко-красного цвета, эластичная, доста- } \\
\text { точно плотная, недостаточно стойкая к } \\
\text { деформации }\end{array}$ \\
\hline \multicolumn{3}{|r|}{ Крахмал } \\
\hline 7 & 2,0 & $\begin{array}{l}\text { Ярко-красного цвета, полупрозрачная } \\
\text { полужидкой консистенции }\end{array}$ \\
\hline 8 & 3,0 & $\begin{array}{l}\text { Ярко-красного цвета, полупрозрачная, } \\
\text { достаточно плотная, не стойкая к дефор- } \\
\text { мации }\end{array}$ \\
\hline \multicolumn{3}{|c|}{ Хитозан } \\
\hline 9 & 2,0 & $\begin{array}{l}\text { Ярко-красного цвета, жидкой } \\
\text { консистенции }\end{array}$ \\
\hline 10 & 2,5 & $\begin{array}{l}\text { Ярко-красного цвета, жидкой } \\
\text { консистенции }\end{array}$ \\
\hline 11 & 3,0 & $\begin{array}{l}\text { Ярко-красного цвета, полужидкой } \\
\text { консистенции }\end{array}$ \\
\hline
\end{tabular}

Способностью к образованию пленок обладают анионные полисахариды - агар-агар и каппа-каррагинан. Нейтральный полисахарид 
крахмал и катионный полисахарид хитозан такой способностью не обладают. Например, пленка на основе нейтрального полисахарида крахмала не держит форму при отделении от поверхности, а раствор для приготовления пленки, содержащий катионный полисахарид хитозан и антоцианы имеет полужидкую консистенцию.

Представленные в таблице 4.26 данные показывают, что наиболее удачные по консистенции пленки, содержащие антоцианы, получаются на основе 1,5 \% агар-агара и 2,0 \% каппа-каррагинана. Данные пленки упругие, пластичные, однако недостаточно стойкие к механической деформации.

Для анализа химических взаимодействий между анионными, нейтральными, катионными полисахаридами и антоцианами, были изучены ИК-спектры антоцианов черной смородины, пленок на основе $1,5 \%$ соответствующего полисахарида и пленок на основе 1,5\% данного полисахарида с антоциановым пигментом.

ИК-спектры образцов пленок на основе 1,5 \% агар-агара, каппакаррагинана, крахмала и хитозана, а также пленок с 1,5 \% их содержанием и с входящим в их состав антоциановым пигментом представлены на рисунках 4.12-4.19. Спектр антоцианов черной смородины представлен на рисунке 1.3. Описание спектра приведено в главе 1.

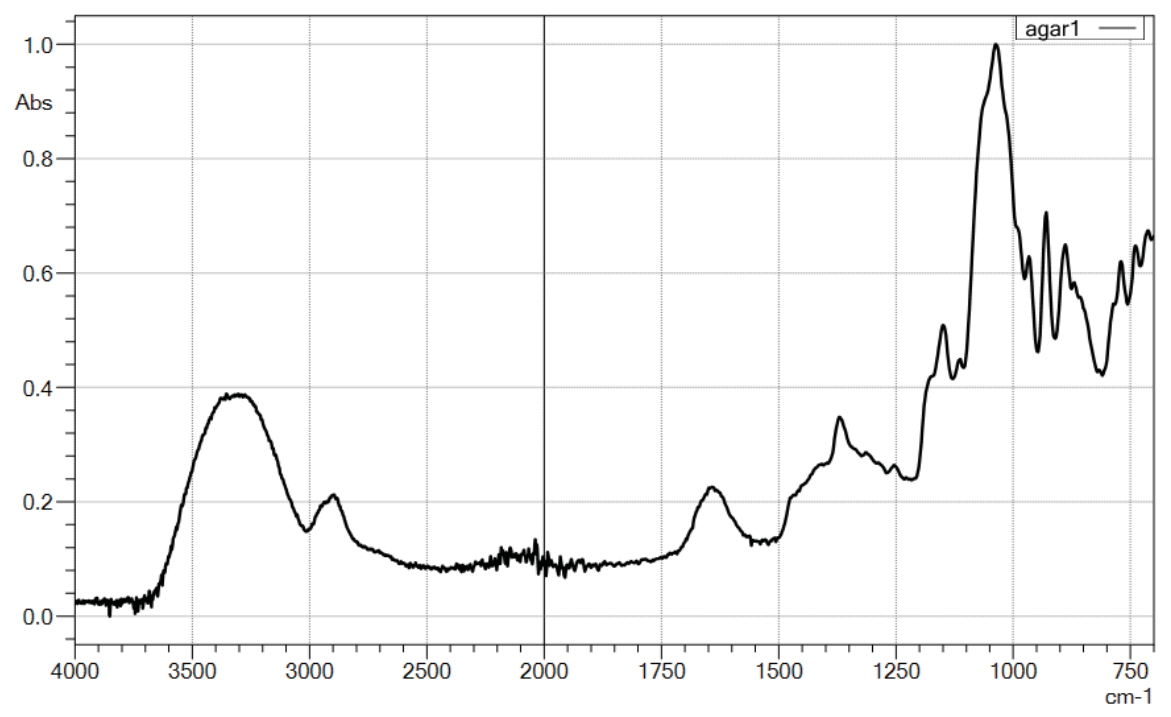

Puc. 4.12. ИК-спектр пленки на основе 1,5 \% агар-агара 


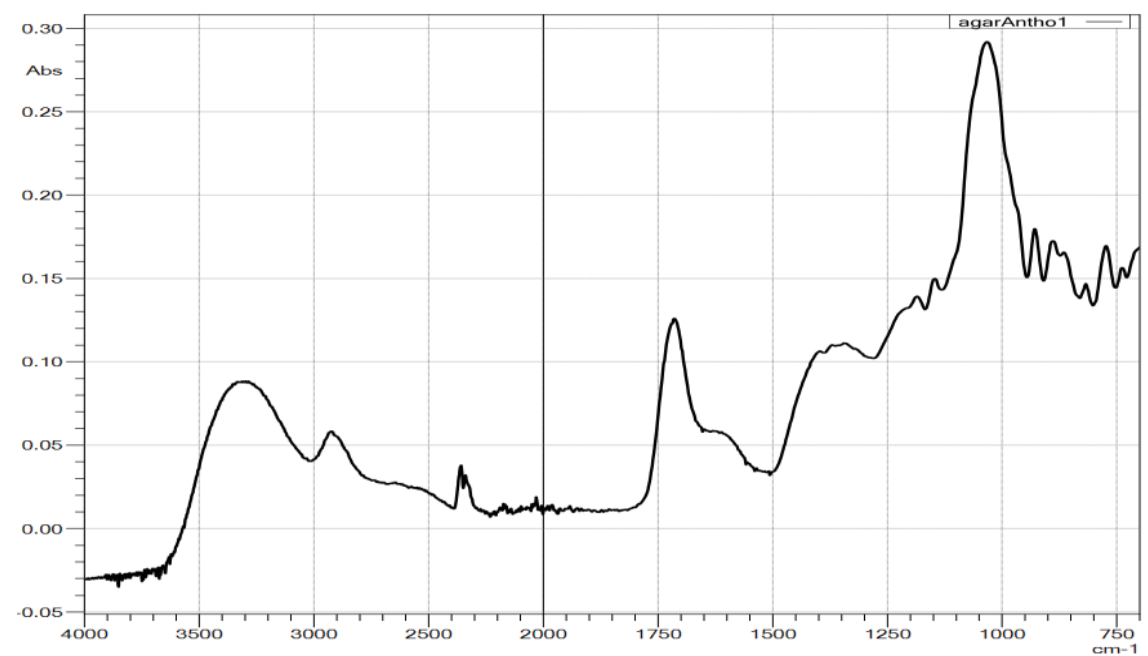

Pис.4.13. ИК-спектр пленки на основе 1,5 \% агар-агара с добавлением антоцианов

Из представленных данных видно, что в целом, ИК-спектры пленок, состоящих только из полисахаридов и пленок на основе полисахаридов и содержащих антоцианы очень похожи. Тем не менее, некоторые различия в относительной интенсивности и положении полос могут наблюдаться [29, 40, 51, 57, 77].

В спектрах антоцианов черной смородины, пленки на основе 1,5 \% агар-агара и пленки на основе 1,5\% агар-агара, с добавлением антоцианов наблюдаются аналогичные похожие широкие полосы, достигающие пика около 3400-3200 $\mathrm{cm}^{-1}$, которым соответствуют колебания межмолекулярных и внутримолекулярных гидроксильных групп [43].

Пик $2897 \mathrm{~cm}^{-1}$ в пленке на основе 1,5 \% агар-агара (рисунок 4.12 и пленке с добавлением антоцианов (рисунок 4.13) обусловлен метильными группами в молекуле агара. В пленке на основе 1,5 \% агар-агара слабая полоса при $1371 \mathrm{~cm}^{-1}$ объясняется низким уровнем сульфатных сложноэфирных связей [28]. Полосы при 1039 и 930 см-1 связаны с С-O связями, присутствующими в 3,6 ангидрогалактозных мостиках [28]. Пик при 890 cм$^{-1}$ связан с C-H связями остатков бета-галактозы. Полоса поглощения при 890-900 см-1 указывает на наличие несульфатированной галактозы (деформационные колебания $\mathrm{C}-\mathrm{H}$ ) в молекуле агара [281]. 
С помощью спектрального анализа можно идентифицировать химические взаимодействия между молекулами структурообразователей и антоцианов [54]. Смещение полос поглощения в спектре с добавлением антоцианов (рисунок 4.13) может означать химическое взаимодействие между вводимыми компонентами. Такое смещение наблюдается относительно полос поглощения при $1039 \mathrm{~cm}^{-1}$ и $1371 \mathrm{~cm}^{-1}$ соответствующим спектру пленки без добавления антоцианов. В пленке с добавлением антоцианов пик при длине волны 1039 $\mathrm{cm}^{-1}$ был перенесен на более низкий волновой уровень в $1031 \mathrm{~cm}^{-1}$. Пик при длине волны $1371 \mathrm{~cm}^{-1}$ практически исчезает. Это свидетельствует о физико-химических взаимодействиях между молекулами антоцианов и агар-агара и образованию между ними водородных связей, что и отражается в изменении полос поглощения в образцах [35]. Кроме того, наблюдается смещение пика при $1639 \mathrm{~cm}^{-1}$ на более низкий волновой уровень $1631 \mathrm{~cm}^{-1}$. Это может свидетельствовать об электростатическом взаимодействии ароматического кольца антоцианов с сульфатными группами агар-агара, приводя к его расширению. Полученные результаты позволяют предположить, что антоцианы были иммобилизованы в матрице пленки на основе агар-агара.

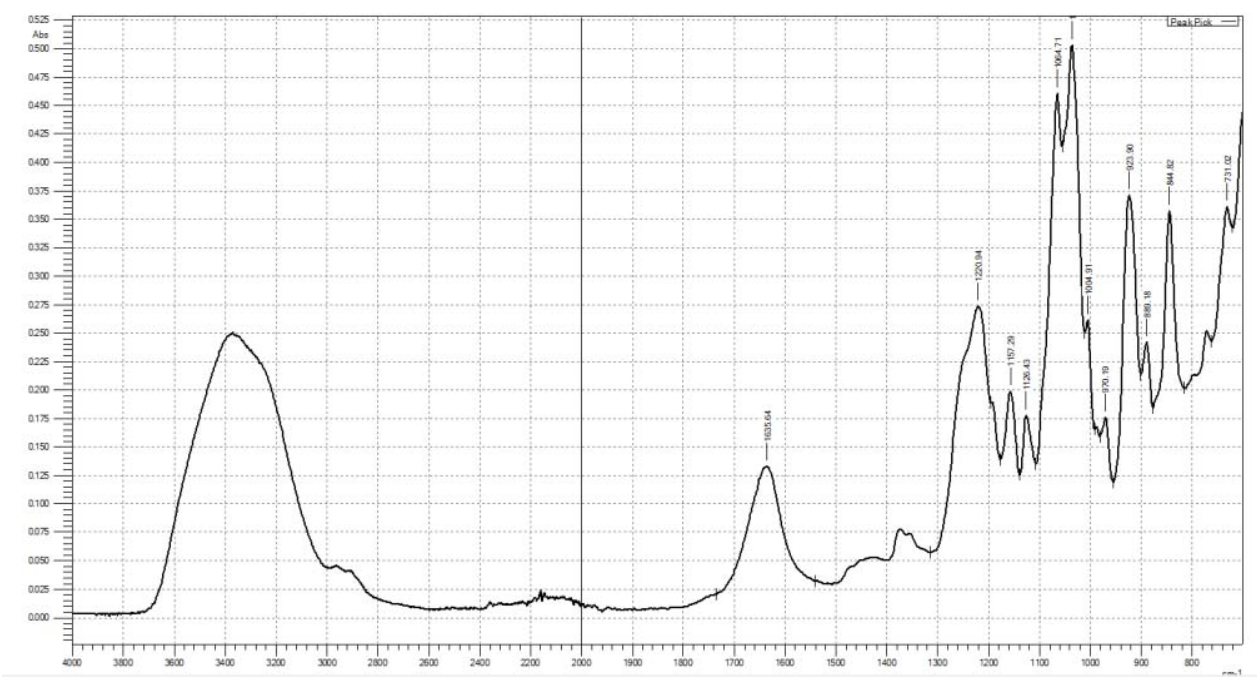

Puc. 4.14. ИК-спектр пленки на основе 1,5 \% каррагинана

Из данных представленных на рисунке 4.14 видно, что основные полосы поглощения каппа-каррагинана $1220 \mathrm{~cm}^{-1}, 923 \mathrm{~cm}^{-1}$ и $844 \mathrm{~cm}^{-1}$ 
отвечают эфирной сульфатной, 3,6-ангидрогалактозной и 0 галактозо-4-сульфатной группам, соответственно. Широкая полоса поглощения с пиком при частоте $3379 \mathrm{~cm}^{-1}$ соответствует колебаниям гидроксильной группы каппа-каррагинана. Полученные данные хорошо согласуются с результатами работ, в которых представлены ИК-спектры для каппа-каррагинана [9].

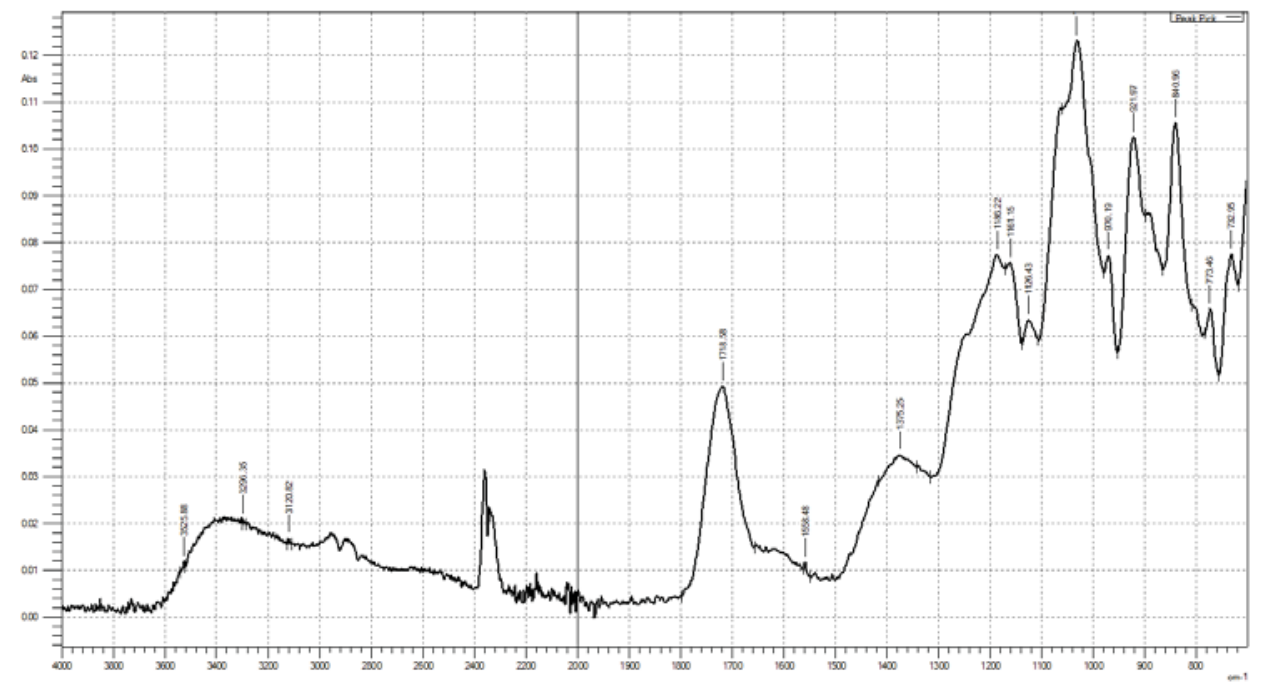

Рuc.4.15. ИК-спектр пленки на основе 1,5 \% каррагинана с добавлением антоцианов

При введении в раствор каппа-каррагинана антоцианов наблюдается низкочастотный сдвиг полосы пропускания сульфатных групп каппа-каррагинана до $1186 \mathrm{~cm}^{-1}$ (рисунок 4.15). Наблюдаемые сдвиги свидетельствуют о взаимодействии положительно заряженного оксония молекулы антоцианов с имеющимися в каппа-каррагинане отрицательно заряженными сульфатными группами. Полученные данные свидетельствуют об электростатической природе формирования полиэлектролитных комплексов антоцианов с полисахаридом.

На представленном ИК-спектре крахмала (рисунок 4.16) наблюдается пик в области $3290 \mathrm{~cm}^{-1}$, он относится к гидроксильной группе. Небольшой пик в $2929 \mathrm{~cm}^{-1}$ приписан к группе С-Н. Пик при $1635 \mathrm{~cm}^{-1}$ предполагает наличие прочно связанной воды в молекуле крахмала. Полосу $1151 \mathrm{~cm}^{-1}$ относят к симметричным колебаниям гликозидных связей [25]. 


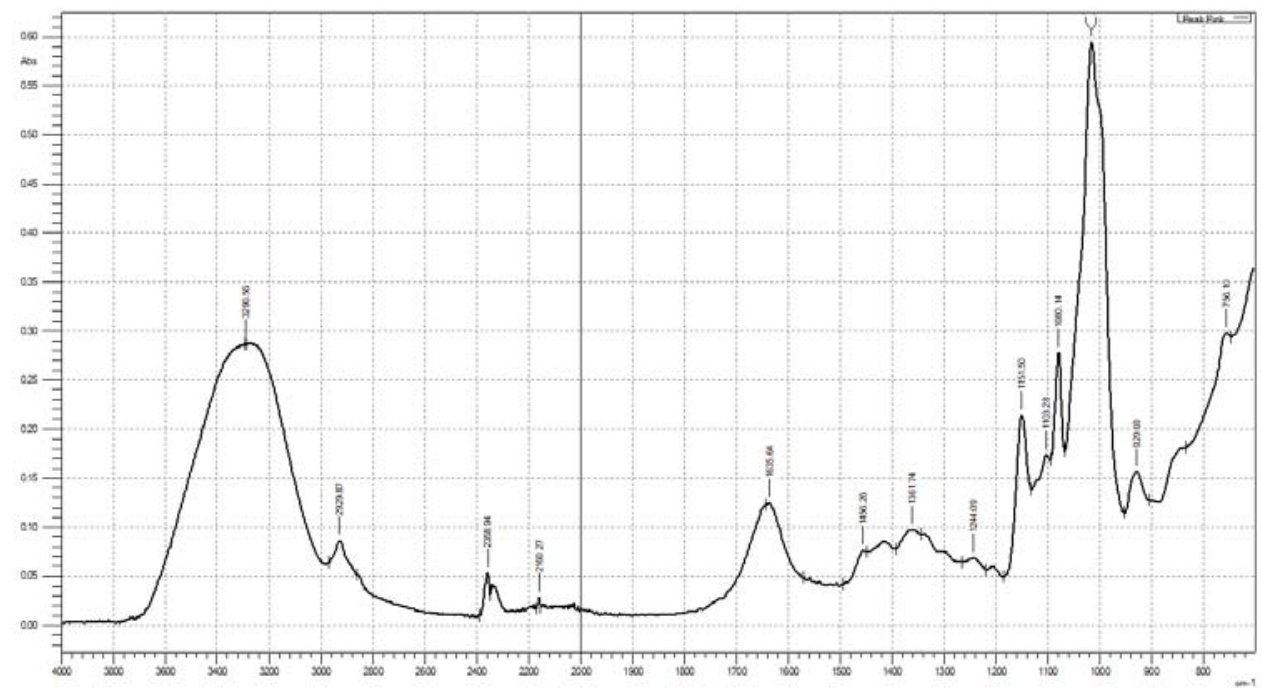

Рuc. 4.16. ИК-спектр пленки на основе 2 \% крахмала

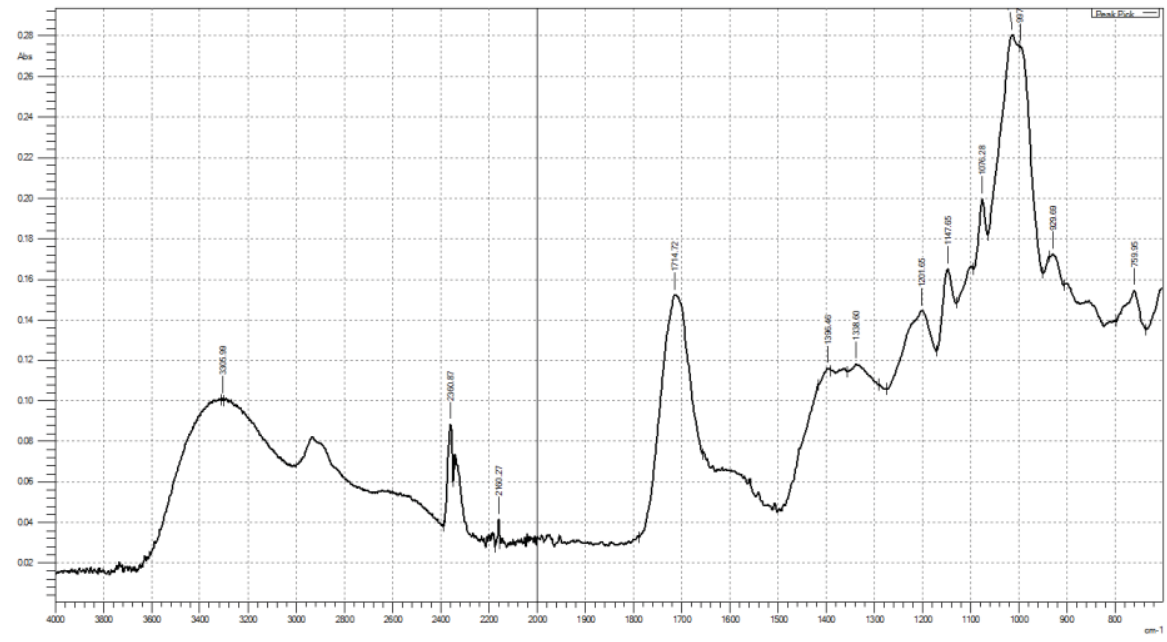

Рuc. 4.17. ИК-спектр пленки на основе 2 \% крахмала с добавлением антоцианов

При введении в состав пленки на основе крахмала антоцианов (рисунок 4.17) происходит сдвиг полосы $3290 \mathrm{~cm}^{-1}$, а также сдвиг и уменьшение пика $1635 \mathrm{~cm}^{-1}$. Причиной таких сдвигов может являться образование водородных связей между гидроксильными группами и гидрофильными группами в молекуле крахмала.

Из результатов, представленных на рисунках 4.18 и 4.19 видно, что полоса колебаний около $3400 \mathrm{~cm}^{-1}$ (OH и $\mathrm{NH}$ ) пленки хитозана обычно расширяется и сдвигается после включения в пленку антоцианов, что обусловлено водородными связями, образующимися между гидроксильными группами антоцианов и амино и гидроксильными группами хитозана $[56,75,78]$. Кроме того, амидная полоса пленки 
хитозана при длине волны $1558 \mathrm{~cm}^{-1}$ практически не уменьшается и не сдвигается. Это свидетельствует о том, что электростатических взаимодействий между положительно заряженным атомом кислорода антоцианов и аминогруппами хитозана не происходит.

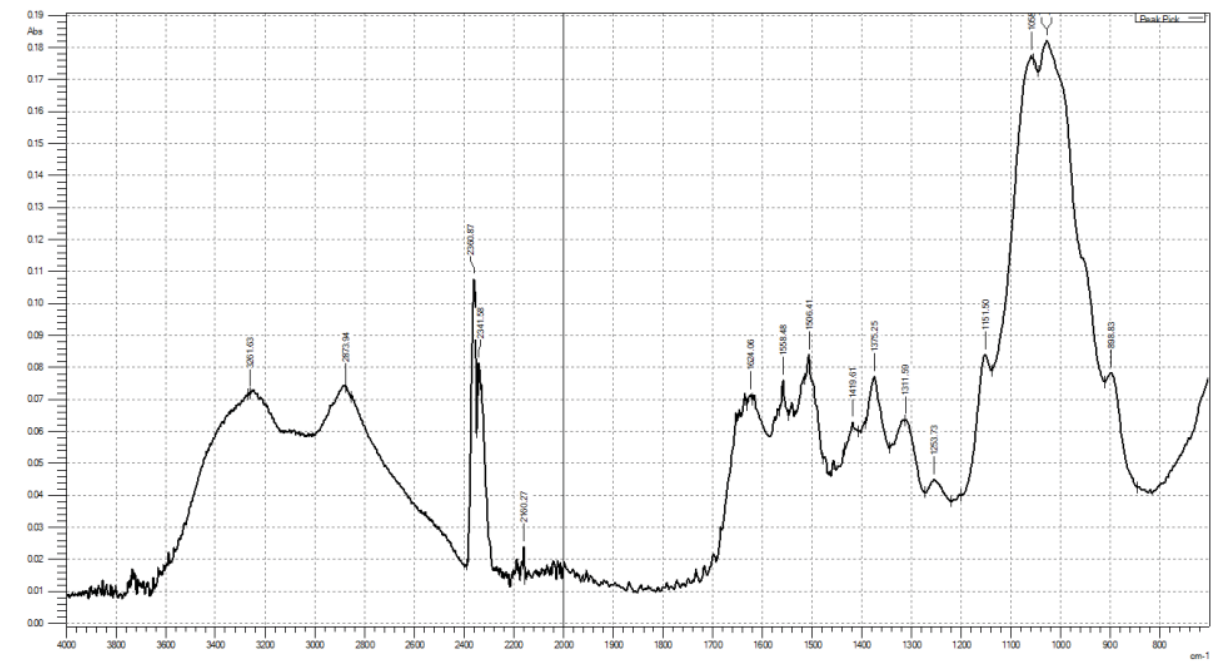

Puc. 4.18. ИК-спектр пленки на основе 2,5 \% хитозана

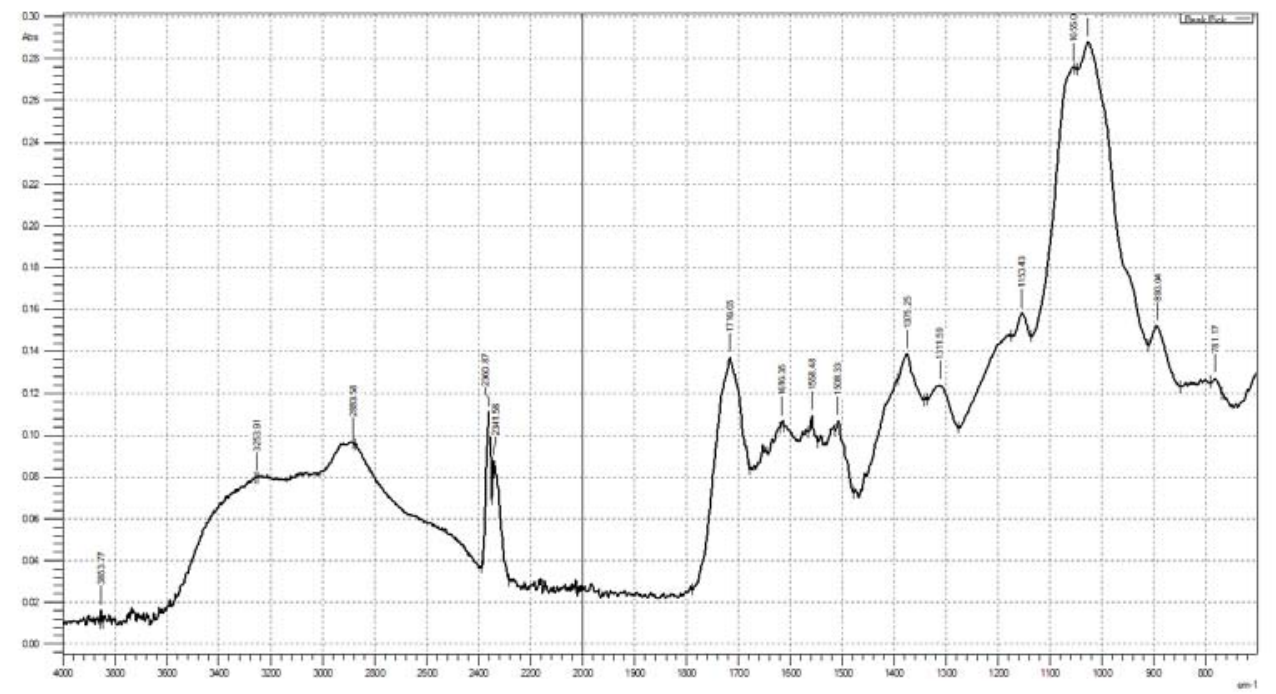

Puc. 4.19. ИК-спектр пленки на основе 2,5 \% хитозана с добавлением антоцианов

Таким образом, определяющим фактором создания пленок на основе полисахаридов с добавлением антоцианов является образование стабильных комплексов между этими соединениями. Кроме того, образование таких комплексов определяется зарядом полисахарида и, соответственно, типом взаимодействия компонентов системы. Благо- 
даря электростатическим взаимодействиям противоположно заряженных антоцианов и анионных полисахаридов, возможно создание на их основе пленок, обладающих ярко-красным цветом и достаточно плотной, но недостаточно стойкой к деформациям консистенцией.

Поскольку пленки с добавлением антоцианов черной смородины предполагалось использовать в качестве индикатора качества для рыбного сырья, в частности, фарша трески, было изучено влияние $\mathrm{pH}$ растворов на изменение окраски пленок. Цветовую реакцию пленок, на основе 1,5 \% агар-агара, содержащих антоцианы оценивали путем погружения их в различные буферные растворы (рH 1-7). При этом пленки оставались неповрежденными благодаря хорошей водостойкости агара. Изменение окраски пленок с добавлением антоцианов черной смородины в диапазоне рН 1-7 представлено на рисунке 4.20.

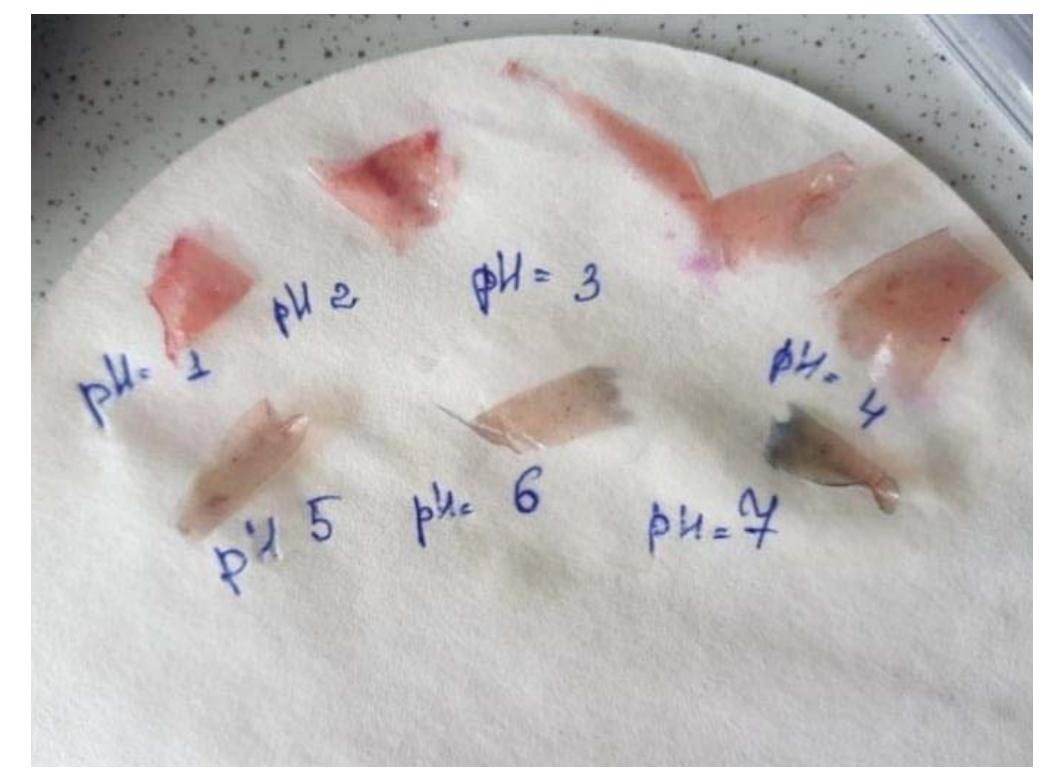

Puc. 4.20. Изменение окраски пленок

с добавлением антоцианов черной смородины

в диапазоне $\mathrm{pH}$ 1-7

Погружение пленок, содержащих антоцианы, в различные буферные растворы приводит к видимому изменению их цвета. При рН растворов 1-2 пленка имеет интенсивно красный цвет. При рН 3-4 пленка приобретает розовую окраску. При погружении в буферные растворы с более высоким рН (5-6) пленка приобретает фиолетовый оттенок. При рН 7 пленка становится сине-зеленой. 
Таким образом, пленка на основе 1,5 \% агар-агара с добавлением антоцианов может быть использована в качестве индикатора изменения кислотности среды.

Полученные пленки использовали как тест-систему для анализа качества фарша трески, поскольку, в процессе хранения рыбного сырья и его порчи происходит изменение активной кислотности $(\mathrm{pH})$ мышечной ткани. Увеличение значений $\mathrm{pH}$ при хранении морского рыбного сырья, обусловлено распадом белковых и экстрактивных азотистых веществ, в частности, образованием значительного количества различных аминов (аммиак, моно-, ди- и триметиламины), получаемых в результате восстановления окиси триметиламина под действием микробиологической порчи [10, 82].

В данной работе было исследовано два образца фарша трески в зависимости от степени свежести. Активную кислотность (pH) свежего фарша определяли сразу после его приготовления. После хранения образцов фарша при комнатной температуре $\left(25^{\circ} \mathrm{C}\right)$ в течение суток, отмечали изменение его органолептических характеристик и значение активной кислотности. Органолептические показатели образцов фарша трески, а также активная кислотность (pH) их мышечной ткани представлены в таблице 4.27 .

При микробиологической порче изменяется активная кислотность $(\mathrm{pH})$ мышечной ткани рыбного сырья. Активная кислотность (pH) мышечной ткани трески находится в пределах 6,7, что характерно для большинства видов свежей рыбы, для которых $\mathrm{pH}$ мяса не превышает 7,05-7,15 [2]. Фарш трески сомнительной свежести имеет значение активной кислотности $(\mathrm{pH})$ равное 8,4 , что свидетельствует о биохимических процессах, происходящих в тканях рыб в процессе хранения и накопления в них продуктов распада белков и экстрактивных веществ, способных изменять реакцию среды.

Фарш трески заворачивали в пленку, содержащую антоцианы, оставляли на 2-7 минут и отмечали изменение окраски пленки. Изменения окраски пленки в зависимости от степени свежести фарша и времени контактирования представлены рисунке 4.21. 
Органолептические показатели образцов фарша трески,

а также активная кислотность (рH) их мышечной ткани

\begin{tabular}{|l|l|l|}
\hline \multicolumn{1}{|c|}{ Показатель } & \multicolumn{1}{|c|}{$\begin{array}{c}\text { Фарш трески } \\
\text { свежий }\end{array}$} & $\begin{array}{l}\text { Фарш трески сомнительной } \\
\text { свежести по истечении суток }\end{array}$ \\
\hline Внешний вид & $\begin{array}{l}\text { Масса однородная, без } \\
\text { отделения влаги, на срезе } \\
\text { измельчение однородное, } \\
\text { тонкое }\end{array}$ & $\begin{array}{l}\text { Масса однородная, } \\
\text { с отделения влаги, } \\
\text { на срезе измельчение } \\
\text { однородное, тонкое }\end{array}$ \\
\hline Цвет & Светло-серый & Серого цвета \\
\hline Консистенция & $\begin{array}{l}\text { Плотная, упругая, } \\
\text { однородная }\end{array}$ & Плотная, однородная \\
\hline $\begin{array}{l}\text { Запах и вкус по- } \\
\text { сле } \\
\text { оттаивания и } \\
\text { варки }\end{array}$ & $\begin{array}{l}\text { Свойственные данному виду } \\
\text { рыбы, без постороннего } \\
\text { запаха и привкуса }\end{array}$ & $\begin{array}{l}\text { С посторонним неприятным } \\
\text { запахом и привкусом } \\
\text { испорченной рыбы }\end{array}$ \\
\hline $\begin{array}{l}\text { Активная } \\
\text { кислотность } \\
\text { (рН) мышечной } \\
\text { ткани }\end{array}$ & \begin{tabular}{l} 
б,6-6,7 \\
\hline
\end{tabular} & 8,4 \\
\hline
\end{tabular}

При контактировании пленки содержащей антоцианы со свежим рыбным фаршем изменение окраски пленки происходило незначительно даже после длительного контактирования.

Напротив, при контакте пленки с фаршем сомнительной свежести изменение цвета пленки начинается уже после 2 минут контактирования. Пленка обесцвечивается, а при увеличении времени контактирования до 7 минут цвет пленки продолжает изменяться и приобретает синеватый оттенок. Эти результаты согласуются с изменением цвета растворов антоцианов при различных значениях $\mathrm{pH}$, а также с изменением цвета пленки, содержащей антоцианы, с розового на фиолетовый, а затем синий.

Поскольку, видимые изменения цвета пленок как индикатора $\mathrm{pH}$ имели тесную связь с изменениями $\mathrm{pH}$ образцов рыбного фарша и эти изменения наблюдались невооруженным глазом, колориметрическая оценка пленки с применением антоцианов может быть использована 
в качестве надежного визуального метода для обнаружения качественных изменений в процессе порчи в рыбных полуфабрикатах.

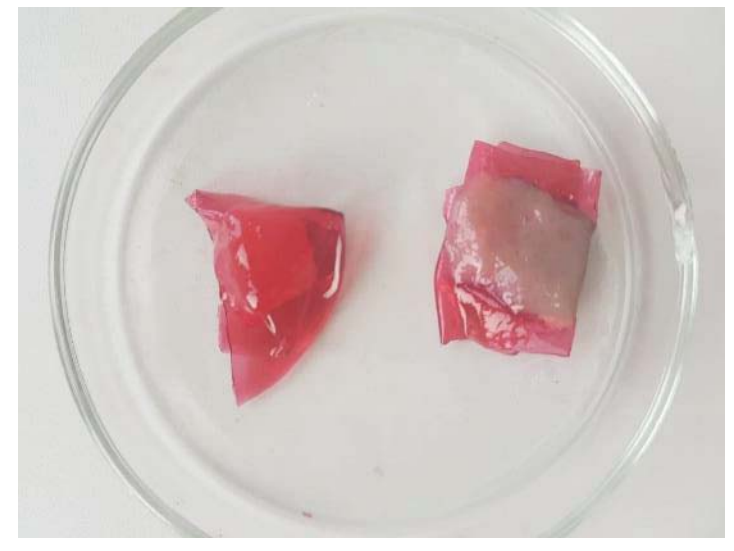

a)

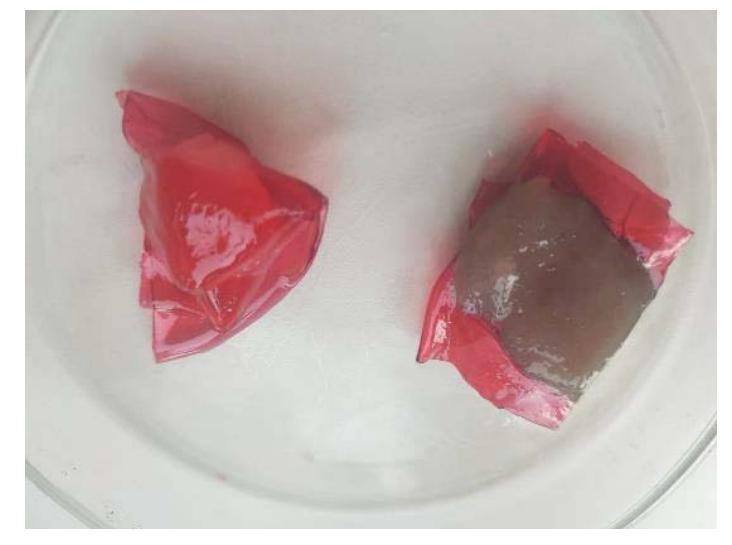

б)

Puc.4.21. Изменение окраски пленки a) свежий фарш и фарш сомнительной свежести после 2 минут контактирования с пленкой,

б) свежий фарш и фарш сомнительной свежести после

7 минут контактирования с пленкой

Для изучения консервирующих свойств пленок, содержащих антоцианы образец свежего фарша, завернутого в пленку, оставляли при температуре $20{ }^{\circ} \mathrm{C}$ на сутки. Внешний вид образца фарша, завернутого в пленку, содержащую антоцианы после хранения при температуре $20{ }^{\circ} \mathrm{C}$ в течение суток представлен на рисунке 4.22.

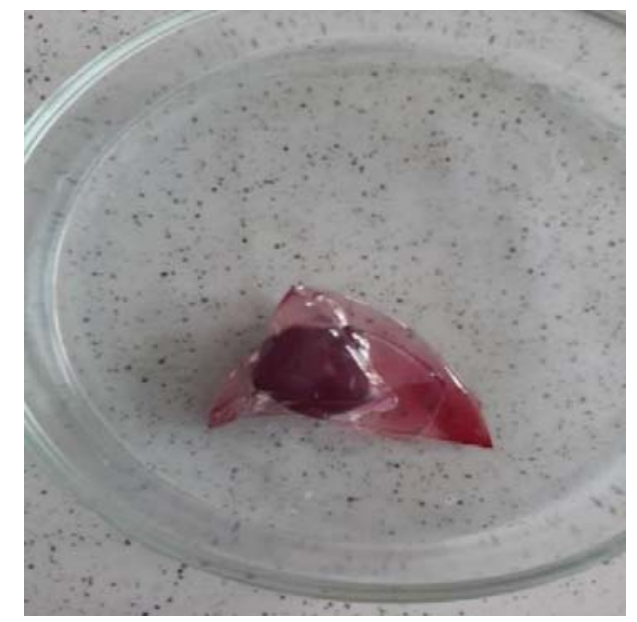

Рuc. 4.22. Внешний вид образца фарша, завернутого в пленку, содержащую антоциановый пигмент после хранения при температуре $20^{\circ} \mathrm{C}$ в течение суток

Из представленных результатов видно, что после суток хранения образца при температуре $20{ }^{\circ} \mathrm{C}$ изменился как цвет пленки, так и фарша. 
Произошло обесцвечивание пленки до розового цвета и окрашивание в красный цвет поверхностных слоев фарша. При этом такие органолептические показатели фарша, как консистенция, запах и вкус не изменились. После суток хранения при температуре $20{ }^{\circ} \mathrm{C}$ консистенция рыбного фарша оставалась плотной, упругой и однородной. Запах и вкус рыбного фарша не изменялись, оставались свойственными данному виду рыбы, посторонний запах и привкус в процессе хранения не появлялись. Органолептические, физико-химические, микробиологические и показатели безопасности пленки на основе 1,5 \% агара, содержащей антоцианы представлены в таблице 4.28.

Таблица 4.28

\section{Органолептические, физико-химические,} микробиологические и показатели безопасности пленки на основе 1,5 \% агара, содержащей антоцианы

\begin{tabular}{|l|l|}
\hline \multicolumn{1}{|c|}{ Показатель } & \multicolumn{1}{|c|}{$\begin{array}{c}\text { Пленка на основе 1,5 \% агара, } \\
\text { содержащая антоцианы }\end{array}$} \\
\hline \multicolumn{2}{|c|}{ Оргелтические показатели } \\
\hline Внешний вид и цвет & $\begin{array}{l}\text { Пленка толщиной 2-3 мм, ярко-красного } \\
\text { цвета, упругая, плотная, недостаточно стойкая } \\
\text { к деформации }\end{array}$ \\
\hline Запах & Яркий, выраженный запах черной смородины \\
\hline Вкус & Кислый, смородиновый \\
\hline \multicolumn{2}{|c|}{ Фимические показатели } \\
\hline Влажность, \% & $14,0 \pm 0,8$ \\
\hline $\begin{array}{l}\text { Содержание антоцианов, } \\
\text { мг/см }\end{array}$ & $8,5 \pm 1,1$ \\
\hline $\begin{array}{l}\text { Антирадикальная активность, } \\
\text { в перерасчете Тторох } \\
\text { эквивалент, мМ }\end{array}$ & $1,84 \pm 0,22$ \\
\hline \multicolumn{2}{|c|}{} \\
\hline КМАФАнМ КОЕ/г не более & Не обнаружено \\
\hline Кишечная палочка в 5 г & Не обнаружено \\
\hline Сальмонеллы в 10 г & Не обнаружено \\
\hline Дрожжи, плесени КОЕ/г & Не обнаружено \\
\hline
\end{tabular}


Окончание табл. 4.28

\begin{tabular}{|l|l|}
\hline \multicolumn{2}{|c|}{ Показатели безопасности ${ }^{1}$} \\
\hline Мышьяк, мг/кг & $0,050 \pm 0,004$ \\
\hline Свинец, мг/кг & $0,010 \pm 0,001$ \\
\hline Ртуть мг/кг & Не обнаружено \\
\hline Кадмий, мг/кг & $0,005 \pm 0,001$ \\
\hline
\end{tabular}

${ }^{1}$ Примечание - Согласно ТР ТС 029/2012 - Допустимое содержание КМАФАнМ КОЕ/Г - не более 5000, кишечная палочка, сальмонеллы - не доп., дрожжи, плесени - не более 500, мышьяк не более 3 мг/кг, свинец не более 5 мг/кг, ртуть не более 1 мг/кг, кадмий не более 1 мг/кг.

Пленка на основе 1,5 \% агар-агара и антоцианов черной сморо-

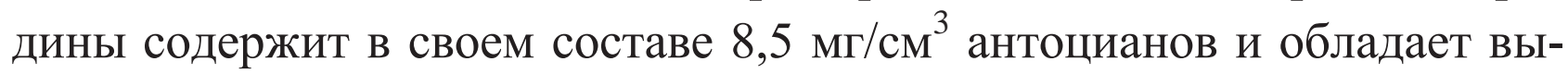
раженной антирадикальной активностью - 1,84 мM Trolox эквивалент.

Микробиологические показатели и показатели безопасности пленки на основе 1,5 \% агар-агара и антоцианов черной смородины не превышают нормативные значения, заложенные в ТР ТС 029/2012 «Требования безопасности пищевых добавок, ароматизаторов и технологических вспомогательных средств» [18].

Для защиты поверхности пищевых продуктов от воздействия вредных факторов, а также удлинения сроков хранения изделий, пленки на основе анионных полисахаридов с добавлением антоцианов использовали для покрытия бисквита основного.

Было приготовлено три образца пленок, содержащих антоцианы это пленки на основе 1,5 \% агар-агара, 1,5 \% агар-агара и 1,5 \% пектина и пленка на основе 1,5\% агар-агара и 1,5 \% пектина с добавлением $20 \%$ сахарозы. Технологическая схема пленки на основе 1,5\% агарагара и 1,5 \% пектина с добавлением 20 \% сахарозы и антоцианов черной смородины представлена на рисунке 4.23. Характеристика данных образцов пленок представлена в таблице 4.29 .

Из результатов, представленных в таблице 4.29 видно, что пленка, содержащая антоцианы и изготовленная на основе 1,5 \% агар-агара, не обладала необходимыми реологическими характеристиками. Пленка была упругая, ломкая, трудно отделяемая от поверхности на которую она выливалась. Оценка вкуса и запаха также 
показала, что данная пленка обладала кислым вкусом и имела, выраженный запах черной смородины.

Таблица 4.29

Характеристика образцов пленок, содержащих антоцианы

\begin{tabular}{|c|c|}
\hline $\begin{array}{l}\text { Образцы пленок, } \\
\text { содержащих } \\
\text { антоцианы }\end{array}$ & Характеристика пленок \\
\hline $1,5 \%$ агара & $\begin{array}{l}\text { Пленка толщиной 2-3 мм, ярко-красного цвета, упру- } \\
\text { гая, плотная, недостаточно стойкая к деформации. } \\
\text { Имеет гладкую блестящую поверхность, обладает кис- } \\
\text { лым вкусом и выраженным запахом черной смородины }\end{array}$ \\
\hline $\begin{array}{c}1,5 \% \text { агара и } 1,5 \% \\
\text { пектина }\end{array}$ & $\begin{array}{l}\text { Пленка толщиной 2-3 мм, ярко-красного цвета, плот- } \\
\text { ная, прочная, выдерживает легкие деформации, но раз- } \\
\text { ламывается при попытке оборачивание бисквита. Име- } \\
\text { ет гладкую поверхность, обладает кислым вкусом и } \\
\text { выраженным запахом черной смородины }\end{array}$ \\
\hline $\begin{array}{l}1,5 \% \text { агара и } 1,5 \% \\
\text { пектина, с добавле- } \\
\text { нием } 20 \% \text { сахарозы }\end{array}$ & $\begin{array}{l}\text { Пленка толщиной 2-3 мм, ярко-красного цвета, плот- } \\
\text { ная, эластичная, достаточно стойкая к деформациям. } \\
\text { Имеет гладкую блестящую поверхность, обладает при- } \\
\text { ятным сладковатым вкусом с легкой кислинкой и запа- } \\
\text { хом черной смородины }\end{array}$ \\
\hline
\end{tabular}

Введение в пленку, содержащую антоцианы и 1,5 \% агар-агара, 1,5 \% пектина позволило улучшить ее реологические свойства. Пленка легко отделялась от поверхности нанесения. Однако при покрытии изделия наблюдалось образование небольших трещин. В данном образце пленки полисахариды агар-агар и пектин проявили синергетическую активность по отношению друг к другу. Добавление пектина делало систему более эластичной и менее хрупкой, а агара - придавало достаточную механическую прочность пленке.

Добавление в пленку, содержащую антоцианы, 1,5 \% агар-агара и 1,5 \% пектина, 20 \% сахарозы оказало пластифицирующее действие на систему. Пленка с добавлением 20 \% сахарозы стала эластичной, достаточно стойкой к деформациям, легко наносилась на изделие. Кроме того, добавление в пленку, содержащую антоцианы, 1,5 \% 
агар-агара и 1,5 \% пектина, 20 \% сахарозы способствовало улучшению ее вкусовых характеристик. Пленка приобретала кисло-сладкий вкус, который более предпочтителен для комбинирования со вкусом мучных кондитерских изделий.

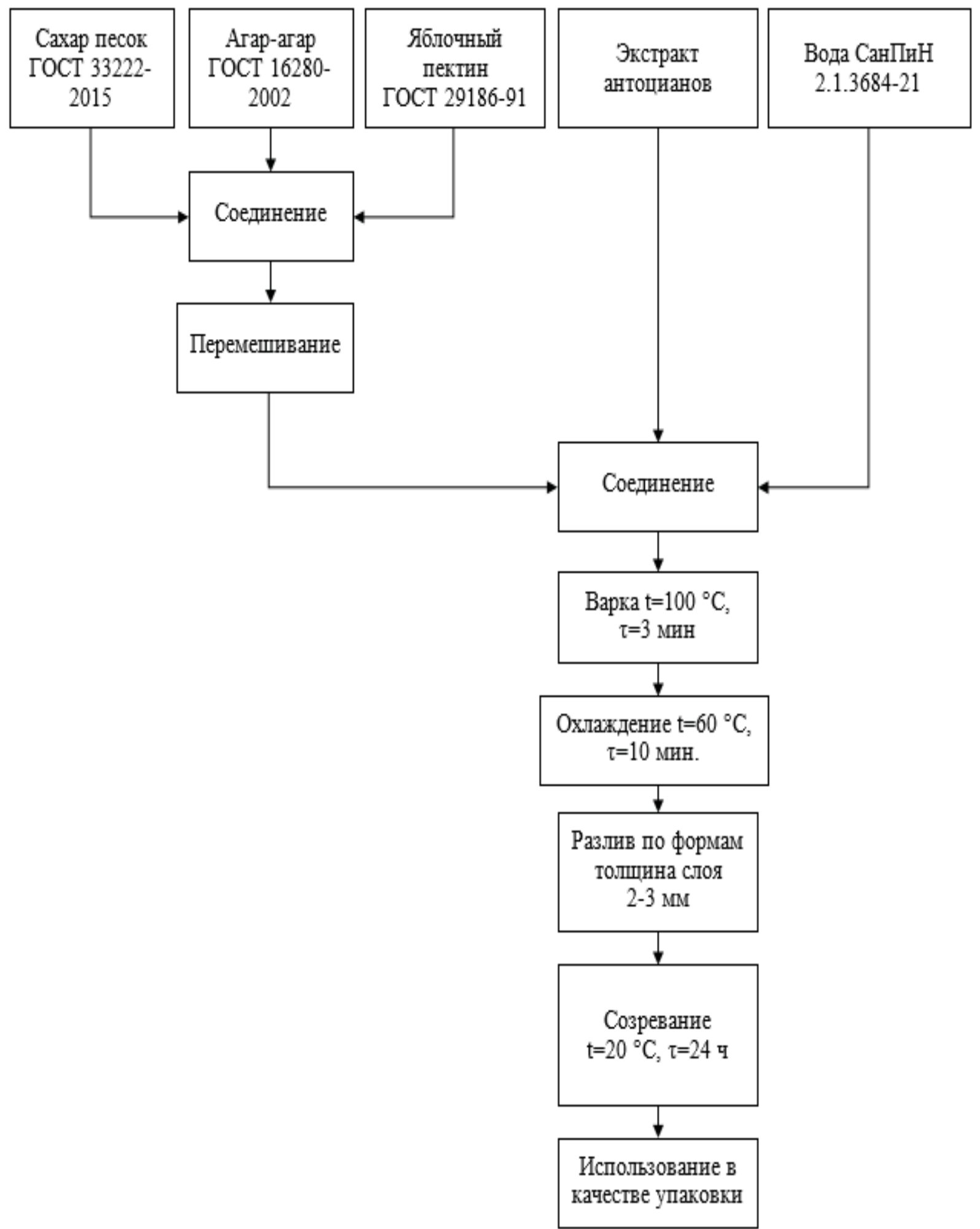

Puc. 4.23. Технологическая схема пленки на основе 1,5 \% агар-агара и $1,5 \%$ пектина с добавлением $20 \%$ сахарозы и антоцианов черной смородины 
Таким образом, пленка, содержащая 1,5 \% агар-агара, 1,5 \% пектина, $20 \%$ сахарозы и антоцианы обладала достаточно высокой прочностью, эластичностью, упругостью и приятным кисло-сладким вкусом.

Пленку, содержащую 1,5 \% агар-агара, 1,5 \% пектина, 20 \% сахарозы и антоцианы использовали для покрытия мучного кондитерского изделия - бисквита.

Было рассмотрено три способа нанесения пленки на изделие. Это оборачивание бисквита пленкой, полив изделия раствором $\left(60{ }^{\circ} \mathrm{C}\right)$ для приготовления пленки и полив раствором $\left(60^{\circ} \mathrm{C}\right)$ для приготовления пленки, замороженного бисквита при температуре $-18{ }^{\circ} \mathrm{C}$ в течение 12 ч. Внешний вид образцов бисквита, покрытых пленкой и политых раствором для приготовления пленки представлен на рисунке 4.24. Оценка образцов бисквита с разными способами нанесения пленки представлена в таблице 4.30 .

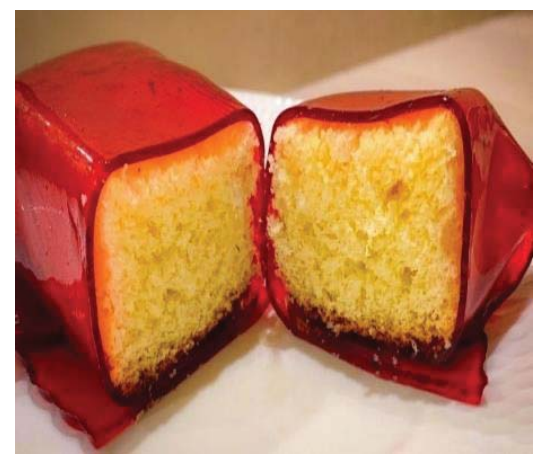

a)

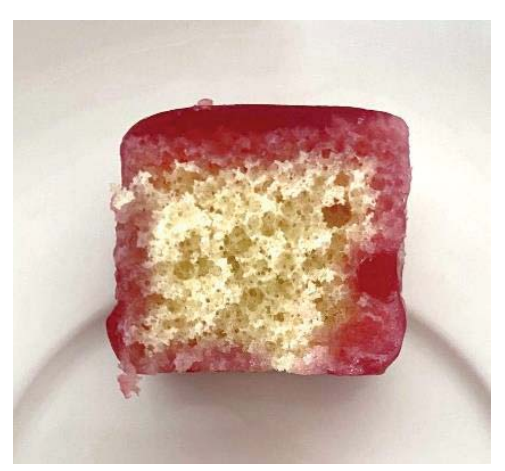

б)

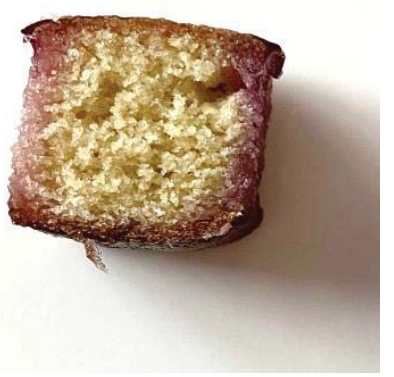

в)

Рuc. 4.24. Внешний вид, образцов бисквита

a) покрытого пленкой, б) политого раствором для приготовления пленки, в) политого раствором для приготовления пленки, замороженного бисквита при температуре $-18{ }^{\circ} \mathrm{C}$ в течение 12 ч

Из представленных результатов видно, что бисквит, покрытый пленкой, имеет блестящую поверхность. Однако наблюдаются небольшие складки в местах изгибов пленки. Покрытие имеет толщину порядка 3-4 мм, что обеспечивает лучшую защиту бисквита от контакта с внешней средой. Также в процессе хранения пленка не окрашивает бисквит. 
Оценка образцов бисквита

\begin{tabular}{|c|c|}
\hline Образцы & Результаты оценки \\
\hline Бисквит, покрытый пленкой & $\begin{array}{l}\text { Блестящая поверхность, складки в местах } \\
\text { изгибов пленки, на разрезе чистый бисквит } \\
\text { без признаков окрашивания составом пленки } \\
\text { и его впитывания. Толщина покрытия 3-4 мм }\end{array}$ \\
\hline $\begin{array}{l}\text { Бисквит, политый раствором } \\
\left(60^{\circ} \mathrm{C}\right) \text { для приготовления } \\
\text { пленки }\end{array}$ & $\begin{array}{l}\text { Блестящая поверхность, покрытие четко по } \\
\text { форме образца, на разрезе наблюдалось вп- } \\
\text { тывание состава пленки вглубь бисквита на } \\
\text { 3-4 мм. Толщина покрытия 1-2 мм }\end{array}$ \\
\hline $\begin{array}{l}\text { Замороженный бисквит при } \\
\text { температуре }-18^{\circ} \mathrm{C} \text { в течение } \\
12 \text { ч, политый раствором }\left(60^{\circ} \mathrm{C}\right) \\
\text { для приготовления пленки }\end{array}$ & $\begin{array}{l}\text { Блестящая поверхность, покрытие четко по } \\
\text { форме образца, на разрезе впитывание со- } \\
\text { става пленки вглубь бисквита около 1-2 мм. } \\
\text { Толщина покрытия } 1 \text { мм. }\end{array}$ \\
\hline
\end{tabular}

Политые раствором для приготовления пленки бисквиты имеют красивую, ровную поверхность без изгибов и заломов. Однако, в связи с тем, что мучные изделия являются высокопористыми системами, происходит проникание состава пленки вглубь бисквита. Предварительное замораживание бисквита при температуре $-18{ }^{\circ} \mathrm{C}$ способствует значительному уменьшению площади проникновения покрытия в глубь изделия, толщина окрашивания изделия уменьшается и составляет 1-2 мм. Вероятно, это происходит из-за низких температур, что способствует быстрому студнеобразованию раствора пленки на поверхности изделия. Кроме того, при данном способе нанесения пленки на бисквит толщина покрытия составляет 1-2 мм.

Таким образом, наилучшими характеристиками обладали образцы бисквита, покрытого пленкой и политого замороженного образца.

Поскольку антоцианы, входящие в состав пленки, обладают высокой антирадикальной активностью, было изучено влияние пленки на сроки годности бисквита. Органолептические показатели образцов бисквита, покрытых пленкой на 1-е и 4-е сутки хранения, представлены в таблице 4.32. В качестве контроля использовали образец бисквита без пленки.

Из представленных результатов видно, что использование пленки, содержащей антоцианы, с пособствует сохранению высоких значений 
органолептических показателей. На 4-е сутки хранения поверхность изделия остается ровной, цвет не изменяется, наблюдается легкое подсыхание пленки. Покрытие пленкой бисквита способствует положительному влиянию на состояние мякиша, сохраняя его упругость и эластичность, в то время как бисквит без покрытия подвержен черствению уже после суток хранения. Таким образом, бисквит, покрытый пленкой, содержащей антоцианы, сохраняет довольно высокие показатели на 4-е сутки хранения, что позволяет продлить его сроки годности на 24 ч.

Для подтверждения пролонгирования сроков годности были определены микробиологические показатели образцов бисквитов, покрытых пленкой, содержащей антоцианы. Оценка микробиологических показателей проводилась у образцов бисквита, покрытых пленкой, содержащей антоцианы, на 1-е, 3-е и 4-е сутки хранения при температуре $20{ }^{\circ} \mathrm{C}$. В качестве контрольного образца использовали бисквит, покрытый полиэтиленовой пленкой на 1-е и 3-е сутки хранения (таблица 4.33).

Из результатов, представленных в таблице 4.32 видно, что микробиологические показатели всех образцов соответствуют нормативным значениям. Таким образом, пленка, содержащая антоцианы, способствует предотвращению микробиологический порчи, и соответственно, пролонгированию сроков годности изделия. Бисквит, покрытый пленкой, содержащей антоцианы, рекомендуется хранить при температуре $20{ }^{\circ} \mathrm{C}$ в течение 96 ч.

Расчет проектной себестоимости пленки, содержащей антоцианы, представлен в таблице 4.31, откуда видно, что отпускная цена пленки составляет 34,28 руб. за 100 г.

Таблица 4.31

Расчет проектной себестоимости пленки, содержащей антоцианы

\begin{tabular}{|l|c|}
\hline \multicolumn{1}{|c|}{ Наименование элементов затрат } & Пленка, содержащая антоцианы \\
\hline Коммерческие расходы & 1997,86 \\
\hline Общая себестоимость & 21976,46 \\
\hline Прибыль от реализации & 6592,94 \\
\hline Оптово-отпускная цена & 28569,4 \\
\hline Отпускная цена & 34283,28 \\
\hline Отпускная цена (100 г) & 34,28 \\
\hline
\end{tabular}


Таблица 4.32

\section{Органолептическая оценка образцов бисквитов в процессе хранения}

\begin{tabular}{|c|c|c|c|c|}
\hline \multirow{2}{*}{ Показатель } & \multicolumn{2}{|c|}{ Бисквит без пленки } & \multicolumn{2}{|c|}{ Бисквит, покрытый пленкой, содержащей антоцианы } \\
\hline & Свежий & Хранение 96 ч & Свежий & Хранение 96 ч \\
\hline $\begin{array}{l}\text { Внешний } \\
\text { вид (поверх- } \\
\text { ность и } \\
\text { форма) }\end{array}$ & $\begin{array}{l}\text { Изделие правильной } \\
\text { формы, пропеченное, } \\
\text { корочка гладкая без } \\
\text { вмятин, надрывов, } \\
\text { трещин и изломов }\end{array}$ & $\begin{array}{l}\text { Изделия правильной } \\
\text { формы, пропеченное, } \\
\text { поверхность высуше- } \\
\text { на и деформирована }\end{array}$ & $\begin{array}{l}\text { Изделие правильной формы, } \\
\text { поверхность бисквита бле- } \\
\text { стящая, равномерно покрыта } \\
\text { пленкой, форма прямоуголь- } \\
\text { ная или полусферическая, } \\
\text { толщина бисквита 3-4 сан- } \\
\text { тиметра, плёнки 2-3 мм }\end{array}$ & $\begin{array}{l}\text { Изделие правильной } \\
\text { формы, поверхность } \\
\text { блестящая, равномерно } \\
\text { покрыта пленкой тол- } \\
\text { щиной 2-3 мм, поверх- } \\
\text { ность пленки слегка } \\
\text { подсохшая }\end{array}$ \\
\hline Цвет & $\begin{array}{l}\text { Корочки - золотистый, } \\
\text { равномерный; мякиша - } \\
\text { ярко-желтый }\end{array}$ & $\begin{array}{l}\text { Корочки - светло- } \\
\text { коричневый; мякиша - } \\
\text { ярко-желтый }\end{array}$ & $\begin{array}{l}\text { У бисквита золотистая ко- } \\
\text { рочка, мякиш ярко-желтый; } \\
\text { пленка - ярко-красная }\end{array}$ & $\begin{array}{l}\text { У бисквита - золоти- } \\
\text { стая корочка; мякиш } \\
\text { ярко-желтый; пленка } \\
\text { бордовая }\end{array}$ \\
\hline $\begin{array}{l}\text { Состояние } \\
\text { мякиша }\end{array}$ & $\begin{array}{l}\text { Мякиш равномернопо- } \\
\text { ристый, упругий, эла- } \\
\text { стичный, без следов } \\
\text { непромеса }\end{array}$ & $\begin{array}{l}\text { Мякиш сухой, крош- } \\
\text { ливый, твердый, } \\
\text { наблюдается сжатие } \\
\text { пор }\end{array}$ & $\begin{array}{l}\text { Равномернопористый, упру- } \\
\text { гий, эластичный, без следов } \\
\text { закала или непромеса }\end{array}$ & $\begin{array}{l}\text { Равномернопористый, } \\
\text { слегка менее упругий и } \\
\text { эластичный, без следов } \\
\text { закала или непромеса }\end{array}$ \\
\hline Вкус & $\begin{array}{l}\text { Приятный сладкий } \\
\text { вкус, без посторонних } \\
\text { привкусов и запахов }\end{array}$ & $\begin{array}{l}\text { Сладкий вкус без по- } \\
\text { сторонних привкусов } \\
\text { и запахов }\end{array}$ & $\begin{array}{l}\text { Сладкий, без посторонних } \\
\text { привкусов, с привкусом смо- } \\
\text { родины }\end{array}$ & $\begin{array}{l}\text { Сладкий, без посто- } \\
\text { ронних привкусов, с } \\
\text { привкусом смородины }\end{array}$ \\
\hline Запах & $\begin{array}{l}\text { Приятный, без посто- } \\
\text { ронних запахов, соот- } \\
\text { ветствует свежевыпе- } \\
\text { ченному тесту }\end{array}$ & $\begin{array}{l}\text { Без посторонних за- } \\
\text { пахов; запах теста не } \\
\text { выражен }\end{array}$ & $\begin{array}{l}\text { Приятный, без посторонних } \\
\text { примесей, соответствует } \\
\text { свежевыпеченному тесту с } \\
\text { выраженным запахом смо- } \\
\text { родины }\end{array}$ & $\begin{array}{l}\text { Приятный, без посто- } \\
\text { ронних примесей, ме- } \\
\text { нее выраженный аро- } \\
\text { мат теста и смородины }\end{array}$ \\
\hline
\end{tabular}


Таблица 4.33

Микробиологических показателей образцов бисквитов

\begin{tabular}{|c|c|c|c|c|c|c|}
\hline \multirow[b]{2}{*}{$\begin{array}{l}\text { Показатель, еди- } \\
\text { ницы измерения }\end{array}$} & & \multicolumn{5}{|c|}{ Результаты испытаний } \\
\hline & $\begin{array}{c}\text { Референтные } \\
\text { значения }\end{array}$ & $\begin{array}{c}\text { Контрольный } \\
\text { образец - } 24 \text { ч } \\
\text { хранения }\end{array}$ & $\begin{array}{c}\text { Контрольный } \\
\text { образец - } 72 \text { ч } \\
\text { хранения }\end{array}$ & $\begin{array}{c}\text { Бисквит, по- } \\
\text { крытый плен- } \\
\text { кой - } 24 \text { ч } \\
\text { хранения }\end{array}$ & $\begin{array}{c}\text { Бисквит, по- } \\
\text { крытый плен- } \\
\text { кой - } 72 \text { ч } \\
\text { хранения }\end{array}$ & $\begin{array}{c}\text { Бисквит, по- } \\
\text { крытый плен- } \\
\text { кой - } 96 \text { ч } \\
\text { хранения }\end{array}$ \\
\hline $\begin{array}{l}\text { Патогенные, в т. } \\
\text { ч. сальмонеллы в } \\
25 \text { г }\end{array}$ & $\begin{array}{l}\text { Не допускают- } \\
\text { ся в } 25 \text { г про- } \\
\text { дукта }\end{array}$ & Не обнаружены & Не обнаружены & Не обнаружены & Не обнаружены & Не обнаружены \\
\hline $\begin{array}{l}\text { Количество ме- } \\
\text { зофильных } \\
\text { аэробных и фа- } \\
\text { культативно- } \\
\text { анаэробных мик- } \\
\text { роорганизмов } \\
\text { (КМАФАнМ), } \\
\text { КОЕ/г }\end{array}$ & Не более $5^{*} 10^{3}$ & $<40$ & $<40$ & $<40$ & $<40$ & $<40$ \\
\hline $\begin{array}{l}\text { Бактерии группы } \\
\text { кишечных пало- } \\
\text { чек (колиформы) } \\
\text { БГКП (колифор- } \\
\text { мы) в 1,0 г }\end{array}$ & $\begin{array}{l}\text { Не допускают- } \\
\text { ся в } 1 \text { г про- } \\
\text { дукта }\end{array}$ & Не обнаружены & Не обнаружены & Не обнаружены & Не обнаружены & Не обнаружены \\
\hline Плесени, КОЕ/г & Не более 50 & $<10$ & 10 & $<10$ & $<10$ & $<10$ \\
\hline Дрожжи, КОЕ/г & Не более 50 & $<10$ & $<10$ & $<10$ & $<10$ & $<10$ \\
\hline
\end{tabular}




\section{Выводы по главе 4}

1. Разработаны технологии кондитерских изделий с добавлением антоцианового красителя и выжимок ягод - мармелада с добавлением 26 \% комплекса антоцианов и агар-агара; зефира с добавлением $13 \%$ комплексов, содержащих антоцианы желатин или яичный альбумин; крема сливочного основного с добавлением 15 мас. \% антоциансодержащего окрашенного структурообразователя и 15 мас. \% концентрированного антоцианового красителя; бисквита круглого «Буше», содержащего 20 \% ягодных выжимок. Проведенная оценка потребительских свойств функциональных продуктов по органолептическим, физико-химическим, микробиологическим и токсикологическим показателям, показала их соответствие требованиям действующим нормативным документам. Доказано, что разработанные функциональные продукты являются безопасными для потребителя.

2. Определена возможность использования комплексов анионных полисахаридов и антоцианов для создания смарт упаковки. Обосновано использование биополимерных пленок, содержащих комплексы антоцианов и анионных полисахаридов, в качестве тестсистемы, позволяющей в режиме реального времени визуально контролировать качество рыбного сырья и активной упаковки, позволяющей защищать поверхность мучного кондитерского изделия бисквита от воздействия вредных факторов и пролонгировать сроки годности продукта на 24 ч. 
Подводя итог выполненных исследований, можно сделать следующие выводы:

1. Показано, что ягодное сырье Дальневосточного региона (черная смородина, жимолость, брусника, калина, лимонник, красника) является источником антоцианов. Определено, что экстракты антоцианов ягод Дальневосточного региона характеризуются высокими антирадикальными свойствами. Оценка биотехнологического потенциала антоцианов, выделенных из ягод Дальневосточного региона, показала, что экстракты антоцианов могут служить основой для создания экологически безопасных пищевых красителей.

2. Показана эффективность экстрагирования антоцианов субмолярным раствором соляной кислоты в течение 60 мин, 0,05-0,15 мас. \% растворами каппа-каррагинана в течение 60 мин и 1-10\% растворами аскорбиновой кислоты в течение 30 мин. Установлено, что экстрагирование антоцианов раствором аскорбиновой кислоты в течение 60 мин приводит к деградации антоцианов.

Определено, что экстрагирование антоцианов полисахаридами определяется зарядом, природой функциональных групп полисахаридов и их количеством в растворе. Установлены наиболее эффективные концентрации анионных полисахаридов для экстрагирования антоцианов.

Установлено, что экстрагирование антоцианов белками - желатином, яичным альбумином и БСА определяется количеством вводимого полимера и реакцией среды. Показано, что максимальной степени извлечения антоцианов соответствует наименьшее значение $\mathrm{pH}$ системы в присутствии 0,6 \% желатина, $0,1 \%$ раствора яичного альбумина и БСА.

Показано, что оптимальными режимами для извлечения антоцианов из ягодного сырья являются их экстрагирование с помощью косвенной ультразвуковой экстракции при температуре $25^{\circ} \mathrm{C}$ в течение 30 мин, прямая ультразвуковая экстракция при температуре $25^{\circ} \mathrm{C}$ в течение 15 мин и извлечение водным раствором при температуре $70{ }^{\circ} \mathrm{C}$ в течение 30 мин. При данных условиях выделяются наиболь- 
шее количество антоцианидинов. Наиболее оптимальным способом для извлечения антоцианов из выжимок ягод является ультразвуковая экстракция при температурах $25^{\circ} \mathrm{C}$ в течение 25 мин и $65^{\circ} \mathrm{C}$ в течение 20 мин.

3. На основе комплексов антоцианов и полимеров - полисахаридов и белков получены экологически безопасные антоциановые красители, представляющие собой вязкие жидкости темно красного цвета, обладающие высокой антирадикальной активностью и содержащий в своем составе биологически активные вещества.

Обоснована технология получения концентрированного красителя, содержащего комплекс антоцианов и пектиновых веществ. Концентрированный антоциановый краситель безопасен для потребителя, имеет густую сиропообразную консистенцию, содержит в своем со-

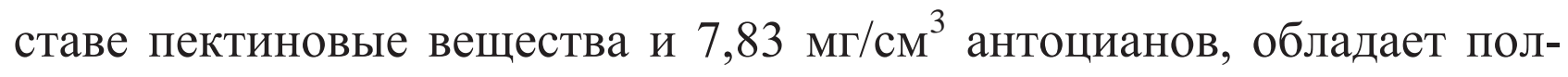
ной растворимостью и выраженной антирадикальной активностью 1,76 мМ Trolox эквивалент.

4. Научно обоснованы и разработаны технологии функциональных продуктов с добавлением антоциановых красителей - мармелада с добавлением $26 \%$ комплекса антоцианов и агар-агара; зефира с добавлением $13 \%$ комплексов, содержащих антоцианы желатин или яичный альбумин; крема сливочного основного с добавлением 15 мас. \% антоциансодержащего окрашенного структурообразователя и 15 мас. \% концентрированного антоцианового красителя; бисквита круглого «Буше», содержащего 20 \% ягодных выжимок. Показано, что разработанные функциональные продукты являются безопасными для потребителя.

Доказано преимущество использования комплексов анионных полисахаридов и антоцианов для создания смарт упаковки. Обосновано использование биополимерных пленок, содержащих комплексы антоцианов и анионных полисахаридов, в качестве интеллектуальной упаковки и тест-системы, позволяющей в режиме реального времени визуально контролировать качество рыбного сырья и активной упаковки, позволяющей защищать поверхность мучного кондитерского изделия бисквита от воздействия вредных факторов и пролонгировать сроки годности продукта на 24 ч. 
1. Бакин, И.А. Изучение химического состава ягод черной смородины в процессе переработки / И.А. Бакин, А.С. Мустафина, П.Н. Лунин // Вестник Крас ГАУ. - 2015. - № 6. - С. 159-162.

2. Богданов, В.Д. Функционально-технологические свойства Дальневосточной красноперки и кефали-лобана / В.Д. Богданов, Ф.Б. Волотка // Известия ТИНРО. - 2013. - Т. 173. - С. 280-292.

3. Болотов, В.М. Пищевые красители: классификация, свойства, анализ, применение: учебное пособие / В.М. Болотов, А.П. Нечаев, Л.А. Сарафанова. - СПб.: ГИОРД. - 2008. - 240 с.

4. Булдаков, А. С. Пищевые добавки / А. С. Булдаков. - Справочник. СПб. - 1996. - 240 с.

5. ГОСТ 33767-2016. Добавки пищевые. Методы идентификации и определения массовой доли основного красящего вещества в пищевом красителе антоцианы Е 163. Введ. 01-07-2017. - М.: Стандартинформ. - 2017. - 12 с.

6. ГОСТ 52349-2005. Продукты пищевые. Продукты пищевые функциональные. Термины и определения. Введ. 2006-07-01. М.: Стандартинформ. - 2006. - 12 с.

7. Думитраш, П.Г. Ультразвуковая экстракция биологически активных соединений из семян томатов / П.Г. Думитраш, М.К. Болога, Т.Д. Шемякова // Электронная обработка материалов. 2016. - № 52(3). - С. 47-52.

8. Истомин, А. В. Гигиенические аспекты использования пектина и пектиновых веществ в лечебно-профилактическом питании: пособие для врачей / А. В. Истомин, Т. Л. Пилат. - М. - 2009. $44 \mathrm{c}$.

9. Маклакова, А.А. Взаимодействие желатины с к-каррагинаном по данным ИК-спектроскопии / А.А. Маклакова, Н.Г. Воронько, С.Р. Деркач, Г.И. Кадырова, К.В. Зотова // Вестник МГТУ. 2014. - Т. 17. -№ 1. - C, 53-60. 
10. Мегеда, Е.В. Биохимические аспекты формирования запаха сырых гидробионтов / Е.В. Мегеда, И.Н. Ким // Известия ТИНРО. - 2008. - Т. 154. - С. 345-371.

11. Михеева, Л.А. Выделение пектина из растительного сырья и изучение его некоторых химических свойств / Л.А. Михеева, А.В. Тры // Вестник ВГУ, серия: Химия, биология, фармация. 2013. - №2. - С. 53-56.

12. МР 2.3.1.1915-04. Рекомендуемые уровни потребления пищевых и биологически активных веществ. - М.: Федеральный центр Госсанэпиднадзора Минздрава России. - 2004. - 41 с.

13. Причко, Т.Г. Химический состав ягод черной смородины, произрастающей на юге России / Т.Г. Причко, М.Г. Германова // Сельскохозяйственные науки и агропромышленный комплекс на рубеже веков. - 2014. - № 5. - С. 93-96.

14. Ратушный, А. С. Сборник рецептур блюд и кулинарных изделий для предприятий общественного питания / А.С. Ратушный, Л. А. Старостина. - М: Экономика. - 1982. - 720 с.

15. Сборник основных рецептур сахаристых кондитерских изделий. / Сост. Н.С. Павлова. - СПб: ГИОРД. - 2000. - 232 с.

16. Сборник рецептур мучных кондитерских и булочных изделий. М.: Профи. - 2017. - 296 с.

17. Таничев, С.С. Антоцианы в плодах и овощах / С.С. Таничев. M. $-1980 .-302 \mathrm{c}$.

18. ТР ТС 029/2012 «Требования безопасности пищевых добаков, ароматизаторов и технологических вспомогательных средств». 01-07-2013. - 308 c.

19. ТР ТС 021/2011 «О безопасности пищевой продукции» [Электронный 197 ресурс]. - Режим доступа: http://docs.cntd.ru/document/902320560

20. Amchova, P. Health safety issues of synthetic food colorants / P. Amchova, H. Kotolova, J. Ruda-Kucerova // Regulatory Toxicology and Pharmacology. - 2015. - Vol. 73 (33). - P. 914-922.

21. Bearth, A. The consumer's perception of artificial food additives: Influences on acceptance, risk and benefit perceptions / A. Bearth, 
M.E. Cousin, M. Siegrist // Food Quality and Preference. - 2014. Vol. 38. - P. 14-23.

22. Bicard, V. Analysis of natural anthocyanins by capillary zone electrophoresis in acidic media. / V. Bicard, A. Faugerousse, R. Brouillard // Journal of Liquid Chromatography and Related Technologies. - 1999. - Vol. 22. - P. 541-550.

23. Britton, G. Biokhimiya prirodnykh pigmentov. [Biochemistry of natural pigments.] / G. Britton. [Cambridge University Press, Cambridge, 1983]. -1986. - $422 \mathrm{pp}$.

24. Brouillard, R. Chemical structure of anthocyanins. / R. Brouillard // Anthocyanins as food colors / ed. by P. Markakis. - New York: Academic Press. - 1982. - Ch. 1. - P. 1-40.

25. Capron, I. Starch in rubbery and glassy states by FTIR spectroscopy / I. Capron, P. Robert, P. Colonna, M. Brogly, V. Planchot // Carbohydrate Polymers. - 2007. - Vol. 68 (2). - P. 249-259.

26. Carocho, M. Natural food additives: Quo vadis? / M. Carocho, P. Morales, I.C.F.R. Ferreira // Trends in Food Science and Technology. - 2015. - Vol. 45 (2). - P. 284-295.

27. Chiou, A. Antocyanins content and antioxidant capacity of Corinthian currants (Vitris Vinifera L. var. Apyrena) / A. Chiou, E. Panagopoulou, F. Gatzali, S. De Marchi, V. Karathanos // Food Chemistry. - 2014. - Vol. 146. - P. 157-165.

28. Chirapart, A. Chemical-composition of agars from a newly reported Japanese Agarophyte, Gracilariopsis-Lemaneiformis / A. Chirapart, M. Ohno, H. Ukeda, M. Sawamura, H. Kusunose // Journal of Applied Phycology. - 1995. - Vol. 7 (4). - P. 359-365.

29. Choi, I., Intelligent $\mathrm{pH}$ indicator film composed of agar/potato starch and anthocyanin extracts from purple sweet potato / I. Choi, J.Y. Lee, M. Lacroix, J. Han // Food Chemistry. - 2017. - Vol. 218. P. 122-128.

30. Chung, C. Enhanced stability of anthocyanin-based color in model beverage systems through whey protein isolate complexation / C. Chung, T. Rojanasasithara, W. Mutilangi, D. Mc Clements // Food Research international. - 2015. - № 7. - P. 761-768. 
31. Clifford, M.N. Anthocyanins - nature, occurrence and dietary burden / M.N. Clifford // Journal of the Science of Food and Agriculture. - 2000 - Vol. 80. № 7. - P. 1063-1072.

32. Cortez, R. Natural pigments: stabilization methods of anthocyanins for food applications / R. Cortez, D.A. Luna-Vital, D. Margulis, E. Gonzalez de Mejia // Comprehensive Reviews in Food Science and Food Safety. - 2017, - Vol. 16 (1). - P. 180-198.

33. Crizel, T.d.M. Biodegradable films based on gelatin and papaya peel microparticles with antioxidant properties / T.d.M. Crizel, A.d.O. Rios, V.D. Alves, N. Bandarra, M. Moldao-Martins, S.H. Flores // Food and Bioprocess Technology. - 2018. - Vol. 11 (3). P. 536-550.

34. D'Alessandro, L. Kinetics of ultrasound assisted extraction of anthocyanins from Aronia melanocarpa (Black chokeberry) wastes / L. D’Alessandro, K. Dimitrov, P. Vauchel, I. Nirov // Chemical engineering research and design. - 2014. - № 92. - P. 1818-1826.

35. El-Hefian, E.A. Preparation and characterization of chitosan/agar blended films: Part 1. Chemical structure and morphology / E.A. El-Hefian, M.M. Nasef, A.H. Yahaya // E-Journal of Chemistry. 2012. - Vol. 9 (3). - P. 1431-1439.

36. Ermak, I.M. Physical and chemical and electron microscopic examination of carrageenans - sulfated polysaccharides of red algae and of the Tichocarpaceae and Gigartinaceaeyu families / I.M. Ermak, A.V. Reunov, L.A. Lapshina, A.O. Byankina (Barabanova), S.Y. Bratskaya, Y.V. Sokolova // Chemistry of Natural Compounds. - 2013. - Vol. 49. - P. 509-511.

37. Flanigan, P.M. Effect of cultivar on phenolic levels, anthocyanin composition, and antioxidant properties in purple basil (Ocimum basilicum L.) / P.M. Flanigan, E.D. Niemeyer // Food Chemistry. 2014. - Vol. 164. - P. 518-526.

38. Gordillo, B. Impact of adding white pomace to red grapes on the phenolic composition and color stability of syrah wines from a warm climate / B. Gordillo, M.J. Cejudo-Bastante, F.J. RodríguezPulido, M.J. Jara-Palacios, P. Ramirez-Perez, M.L. GonzálezMiret, 
F.J. Heredia // Journal of Agricultural and Food Chemistry. - 2014. Vol. 62 (12). - P. 2663-2671.

39. Giusti, M.M. Acylated anthocyanins from edible sources and their applications in food systems / M.M. Giusti, R.E. Wrolstad // Biochemical Engineering Journal. - 2003. - Vol. 14 (3). - P. 217-225.

40. Halász, K. Black chokeberry (Aronia melanocarpa) pomace extract immobilized in chitosan for colorimetric $\mathrm{pH}$ indicator film application / K. Halász, L. Csóka // Food Packaging and Shelf Life. - 2018. - Vol. 16. - P. 185-193

41. He, J. Anthocyanins: Natural colorants with health-promoting properties / J. He, M.M. Giusti // Annual Review of Food Science and Technology. - 2010. - Vol. 1. - P. 163-187. 10.1146/annurev.food.080708.100754.

42. Hernández-Herrer, J.A. Influence of rutin and ascorbic acid in colour, plum anthocyanins and antioxidant capacity stability in model juices / J.A. Hernández-Herrer, M.J. Frutos // Food Chemistry. 2015. - Vol. 173. - P. 495-500.

43. Hong, J. Effect of pulsed electric fields assisted acetylation on morphological, structural and functional characteristics of potato starch / J. Hong, R. Chen, X.A. Zeng, Z. Han // Food Chemistry. 2016. - Vol. 192. - P. 15-24.

44. Hui, C. Anticancer activities of an anthocyanin-rich extract from black rice against breast cancer cells in vitro and in vivo / C. Hui, Y. Bi, Y. Xiaopin, Y. Lon, C. Chunye, M. Mantian, L. Wenhua // Nutrition and Cancer. - 2010. - Vol. 62 (8). - P. 1128-1136.

45. Iorizzo, M. A cluster of MYB transcription factors regulates anthocyanin biosynthesis in carrot (Daucus carota L.) root and petiole / $\mathrm{M}$. Iorizzo, P.F. Cavagnaro, H. Bostan, Y. Zhao, J. Zhang, P.W. Simon // Front. Plant Sci. - 2019. - Vol. 9. - A. 1927.

46. Jing, P. Optimization of purification conditions of radish (Raphanus sativus L.) anthocyanin-rich extracts using chitosan / P. Jing, S. Ruan, Y. Dong, X. Zhang, J. Yue, J. Kan, M. Slavin, L. Yu // Food Science and Technology. - 2011. - № 44. - P. 2097-2103. 
47. Konczak, L. Antocyanins - more than nature's colours / L. Konczak, W. Zhang // Journal of Biomedicine and Biotechnology. - 2004. - № 5. - P. 239-240.

48. Kong, J.M. Analysis and biological activities of anthocyanins / J.M. Kong, L.S. Chia, N.K. Goh, T.F. Chia, R. Brouillard // Phytochemistry. - 2003. - Vol. 64. - P. 923-933.

49. Lee, J. Extraction of anthocyanins and polyphenolics from blueberry processing waste / J. Lee, R.E. Wrolstad // Journal of food science. 2004 - Vol. 69. - № 7. - P. C564-C574.

50. Li, D. Health benefits of anthocyanins and molecular mechanisms: Update from recent decade / D. Li, P. Wang, Y. Luo, MZhao, F. Chen // Critical Reviews in Food Science and Nutrition. - 2017, - Vol. 57 (8). - P. 1729-1741.

51. Liang, T. A pH-sensing film from tamarind seed polysaccharide with litmus lichen extract as an indicator / T. Liang, L. Wang // Polymers. - 2018. - Vol. 10 (1). - P. 13.

52. Liu, S. Buffering color fluctuation of purple sweet potato anthocyanins to acidity variation by surfactants / S. Liu, Y. Fu, S. Nian // Food Chemistry. - 2014. - № 162. - P. 16-21.

53. Martins, N. Food colorants: Challenges, opportunities and current desires of agro-industries to ensure consumer expectations and regulatory practices / N. Martins, C.L. Roriz, P. Morales, L. Barros, I.C.F.R. Ferreira // Trends in Food Science \& Technology. - 2016. - Vol. 52. - P. 1-15.

54. Matsuhiro, B. Vibrational spectroscopy of seaweed galactans / B. Matsuhiro // Hydrobiologia. - 1996. - Vol. 327 (1). - P. 481489.

55. Mazza, G. Anthocyanins in fruits, vegetables and grains / G. Mazza, E. Miniati. - Boca Raton: CRC Press Inc. - 1993. - 362 p.

56. Merz, B. A novel colorimetric indicator film based on chitosan, polyvinyl alcohol and anthocyanins from jambolan (Syzygium cumini) fruit for monitoring shrimp freshness / B. Merz, C. Capello, G.C .Leandro, D.E. Moritz, A.R. Monteiro, G.A. Valencia // International Journal of Biological Macromolecules. - 2020. - Vol. 153. - P. 625-632. 
57. Mohammadalinejhad, S. Immobilization of Echium amoenum anthocyanins into bacterial cellulose film: A novel colorimetric $\mathrm{pH}$ indicator for freshness/spoilage monitoring of shrimp / S. Mohammadalinejhad, H. Almasi, M. Moradi // Food Control. - 2020. Vol. 113. - A. 107169.

58. Mohan, C.O.A. Active and intelligent packaging systemsapplication in seafood / C.O.A. Mohan, C.N. Ravishankar // World Journal of Aquaculture Reserch \& Development. - 2019. - Vol. 1. - P. 10-16.

59. Mojica, L. Black bean anthocyanin-rich extracts as food colorants: Physicochemical stability and antidiabetes potential / L. Mojica, M. Berhow, E. Gonzalez de Mejia // Food Chemistry. - 2017. Vol. 229. - P. 628-639.

60. Musso, Y.S. Smart gelatin films prepared using red cabbage (Brassica oleracea L.) extracts as solvent / Y.S. Musso, P.R. Salgado, A.N. Mauri // Food Hydrocolloids. - 2019. - Vol. 89. - P. 674-681.

61. Nakaishi, H. Effect of black currant anthocyaniside intake on dark adaptation and VDT work-induced transient refractive alteration in healthy humans / H. Nakaishi, H. Matsumoto, S. Tominaga, M. Hirayama // Altern. Med. Rev. - 2000. - V. 5. - P. 553-562.

62. Nakanishi, K. Infrared absorption spectroscopy / K. Nakanishi, P.H. Solomon - 2nd ed. Holden-Day, INC, San Francisco. - 1977. $287 \mathrm{p}$.

63. Nems, A. Anthocyanin and antioxidant activity of snacks with colored potato / A. Nems, A. Peksa, A. Kucharska, A. Sokol-Letowska, A. Kita, W. Drozdz, K. Hamouz // Food Chemistry. - 2015. Vol. 172. - P. 175-182.

64. Nielsen, R. Developments in natural colourings / R. Nielsen, S. Holst, D.B. MacDougall. - Colour in food: Improving quality, CRC Press. - 2002. - P. 331-350.

65. Pappas, C.S. Quantitative determination of anthocyanins in three sweet cherry varieties using diffuse reflectance infrared Fourier transform spectroscopy / C.S. Pappas, C. Takidelli, E. Tsantili, P.A. Tarantilis, M.G. Polissiou // Journal of Food Composition and Analysis. - 2011. - Vol. 24 (1). - P. 17-21. 
66. Pasias, I.N. Food colours for bakery products, snack foods, dry soup mixes, and seasonings / I.N. Pasias, A.G. Asimakopoulos, N.S. Thomaidis, M. Scotter (Ed.). - Colour additives for foods and beverages. - 2015. - P. 211-226.

67. Patras, A. Effect of thermal processing on anthocyanin stability in foods; mechanisms and kinetics of degradation / A. Patras, N. Brunton, C. O’Donnell, B. Tiwari // Trends in food science and technology. - 2010. - № 21. - P. 3-11.

68. Pereira, V.A. Active chitosan/PVA films with anthocyanins from Brassica oleraceae (Red Cabbage) as time-temperature indicators for application in intelligent food packaging / V.A. Pereir, I.N.Q. Jr. de Arruda, R. Stefani // Food Hydrocolloids. - 2015. - Vol. 43. P. 180-188.

69. Potera, C. The artificial food dye blues / C. Potera // Environmental Health Perspectives. - 2010. - Vol. 118 (10). - A. 428.

70. Pourcel, L. The formation of anthocyanic vacuolar inclusions in Arabidopsis thaliana and implications for the sequestration of anthocyanin pigments / L. Pourcel, N.G. Irani, Y. Lu, K. Riedl, S. Schwartz, E. Grotewold // Mol. Plant. - 2010. - Vol. 3. - P. 7890.

71. Silva-Pereira, M.C. Chitosan/corn starch blend films with extract from Brassica oleraceae (red cabbage) as a visual indicator of fish deterioration / M.C. Silva-Pereira, J.A. Teixeira, V.A. PereiraJunior, R. Stefani // LWT-Food Science and Technology. - 2015. Vol. 61 (1). - P. 258-262.

72. Sui, X. Combined effect of $\mathrm{pH}$ and High temperature on the stability and antioxidant capacity of two anthocyanins in aqueous solution / X. Sui, X. Dong, W. Zhou // Food Chemistry. - 2014. - № 163. P. 163-170.

73. Sukhtezari, S. Development of bacterial cellulose based slowrelease active films by incorporation of Scrophularia striata Boiss / S. Sukhtezari, H. Almasi, S. Pirsa, M. Zandi, M. Pirouzifard // Extract. Carbohydrate Polymers. - 2017. - Vol. 156. - P. 340-350.

74. Veridiana, $\mathrm{V}$. The high ascorbic acid content is the main cause of the low stability of anthocyanin extracts from acerola / V. Veridi- 
ana, Z.M. Adriana // Food Chemistry. - 2007. - Vol. 103. - P. 935943.

75. Wang, S. Packaging films formulated with gelatin and anthocyanins nanocomplexes: Physical properties, antioxidant activity and its application for olive oil protection / S. Wang, P. Xia, S. Wang, J. Liang, Y. Sun, P. Yue, et al. // Food Hydrocolloids. - 2019. Vol. 96. - P. 617-624.

76. Wrolstad, R.E. Alternatives to those artificial FD\&C food colorants / R.E. Wrolstad, C.A. Culver // Annual Review of Food Science and Technology. - 2012. - Vol. 3 (1). - P. 59-77.

77. Wu, C. Novel konjac glucomannan films with oxidized chitin nanocrystals immobilized red cabbage anthocyanins for intelligent food packaging / C. Wu, Y. Li, J. Sun, Y. Lu, C. Tong, L. Wang, et al. // Food Hydrocolloids. - 2020. - Vol. 98. - A. 105245.

78. Yong, H. Antioxidant and $\mathrm{pH}$-sensitive films developed by incorporating purple and black rice extracts into chitosan matrix / H. Yong, J. Liu, Y. Qin, R. Bai, X. Zhang, J. Liu // International Journal of Biological Macromolecules. - 2019. - VoL. 137. - P. 307-316.

79. You, Y. Cyanidin-3-glucoside attenuates high-fat and high-fructose diet-induced obesity by promoting the thermogenic capacity of brown adipose tissue / Y. You, X. Han, J. Guo, Y. Guo, M. Yin, G. Liu,

J. Zhan // Journal of Functiomal Foods. - 2018. - Vol. 41. - P. 62-71.

80. Yousefi, H. Intelligent food packaging: A review of smart sensing technologies for monitoring food quality / H. Yousefi, H.M. Su, S.M. Imani, K.M. Alkhaldi, C.D. Filipe, T.F. Didar // ACS Sensors. 2019. - Vol. 4. - P. 808-821.

81. Zhang, Z.F. Purple sweet potato color attenuates oxidative stress and inflammatory response induced by $\mathrm{D}_{\text {-galactose in mouse liver / }}$ Z.F. Zhang, S.H. Fan, Y.L. Zheng, J. Lu, D.M. Wu, Q. Shan, et al. // Food and Chemical Toxicology. - 2009. - Vol. 47. - P. 496-501.

82. Zhang, J. Preparation of an intelligent $\mathrm{pH}$ film based on biodegradable polymers and roselle anthocyanins for monitoring pork freshness / J. Zhang, X. Zou, X. Zhai, X. Huang, C. Jiang, M. Holmes // Food Chemistry. - 2019. - Vol. 272. - P. 306-312. 


\section{Приложение}

Тандемная масс-спектрометрия (ВЭЖХ-МС/МС) и их масс-спектры образцов антоцианов, экстрагированных различными способами
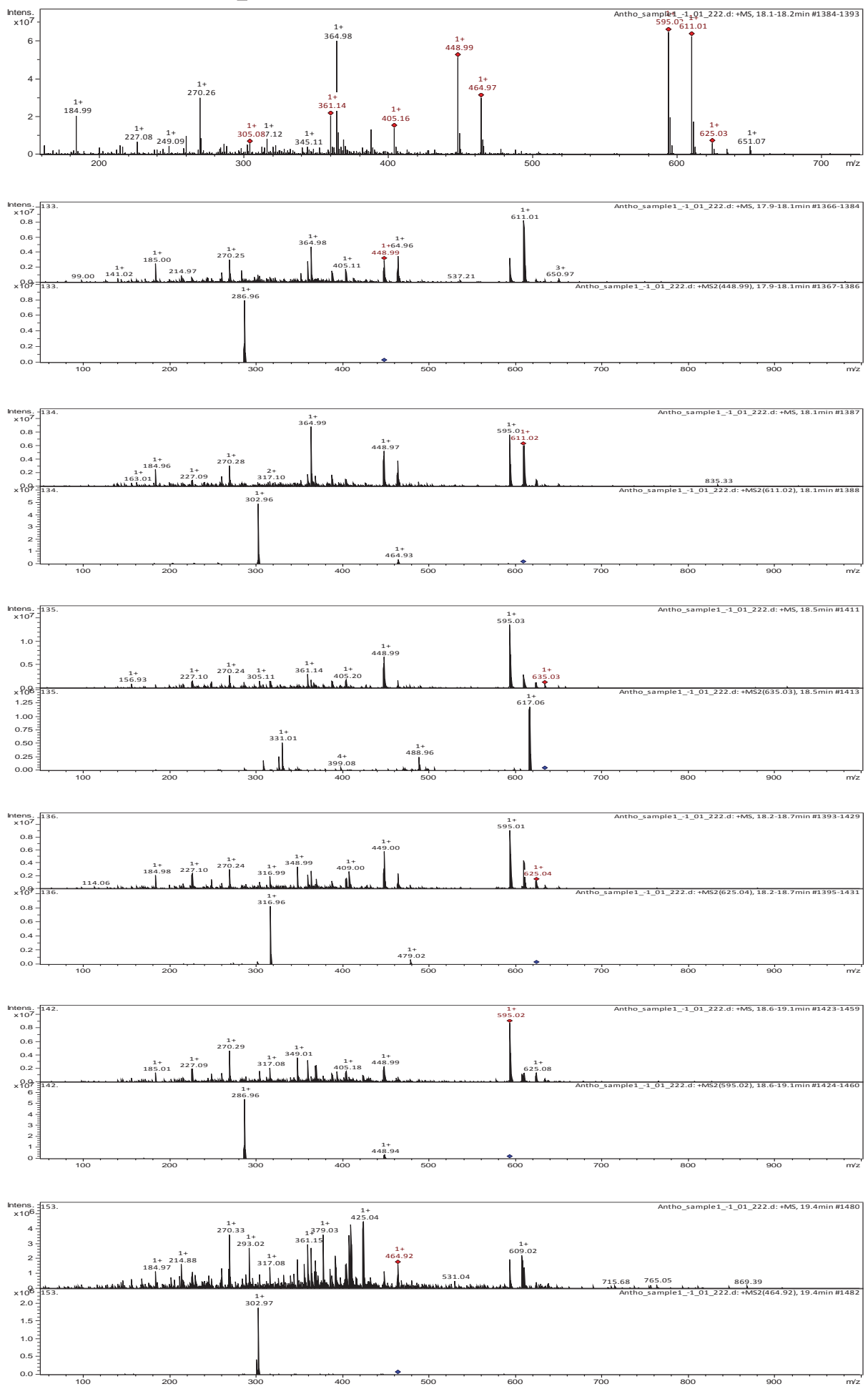

Puc. 1. Масс-спектр пиков антоцианидинов из образца 1 

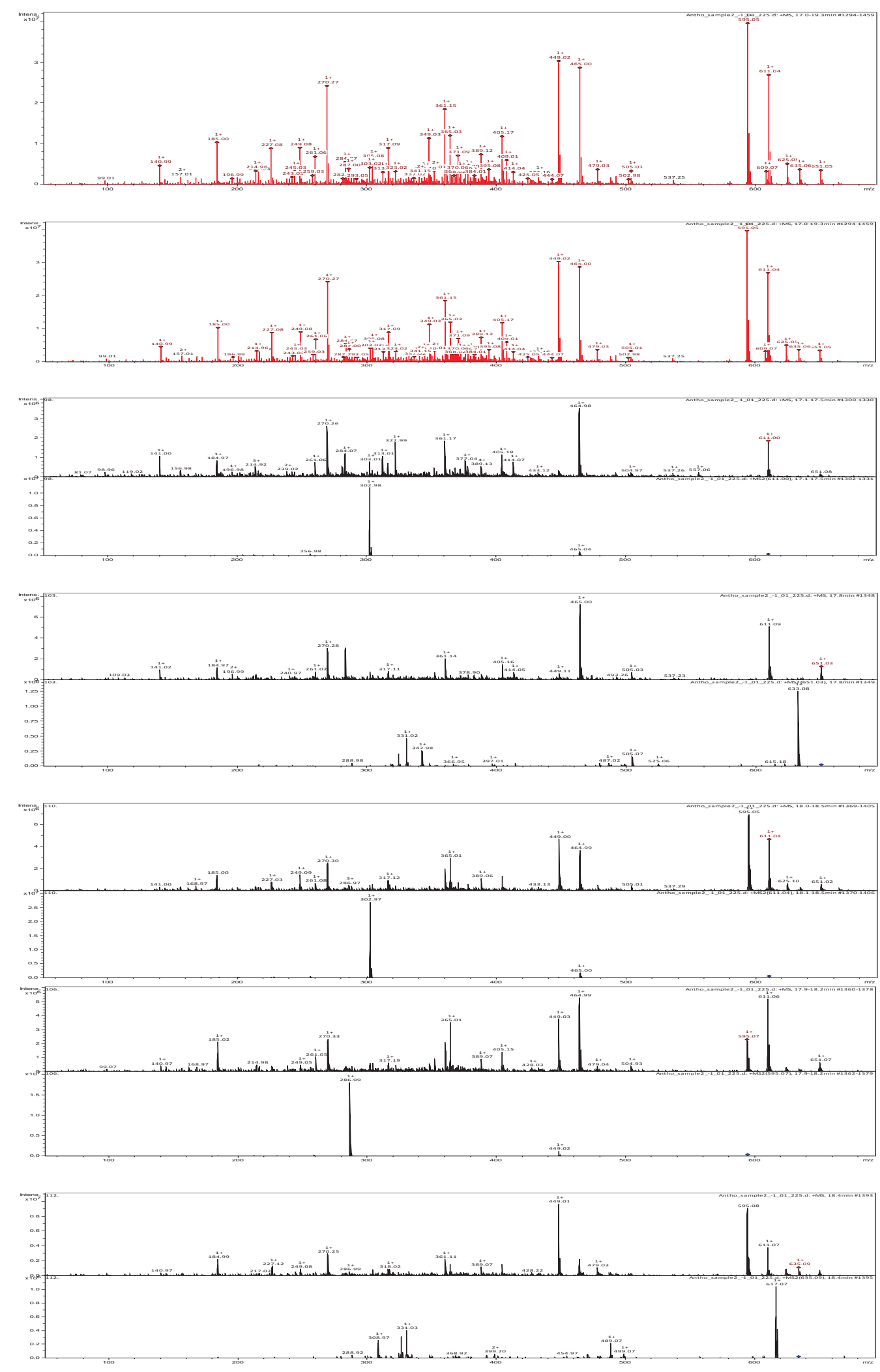

Puc. 2. Масс-спектр пиков антоцианидинов из образца 2 

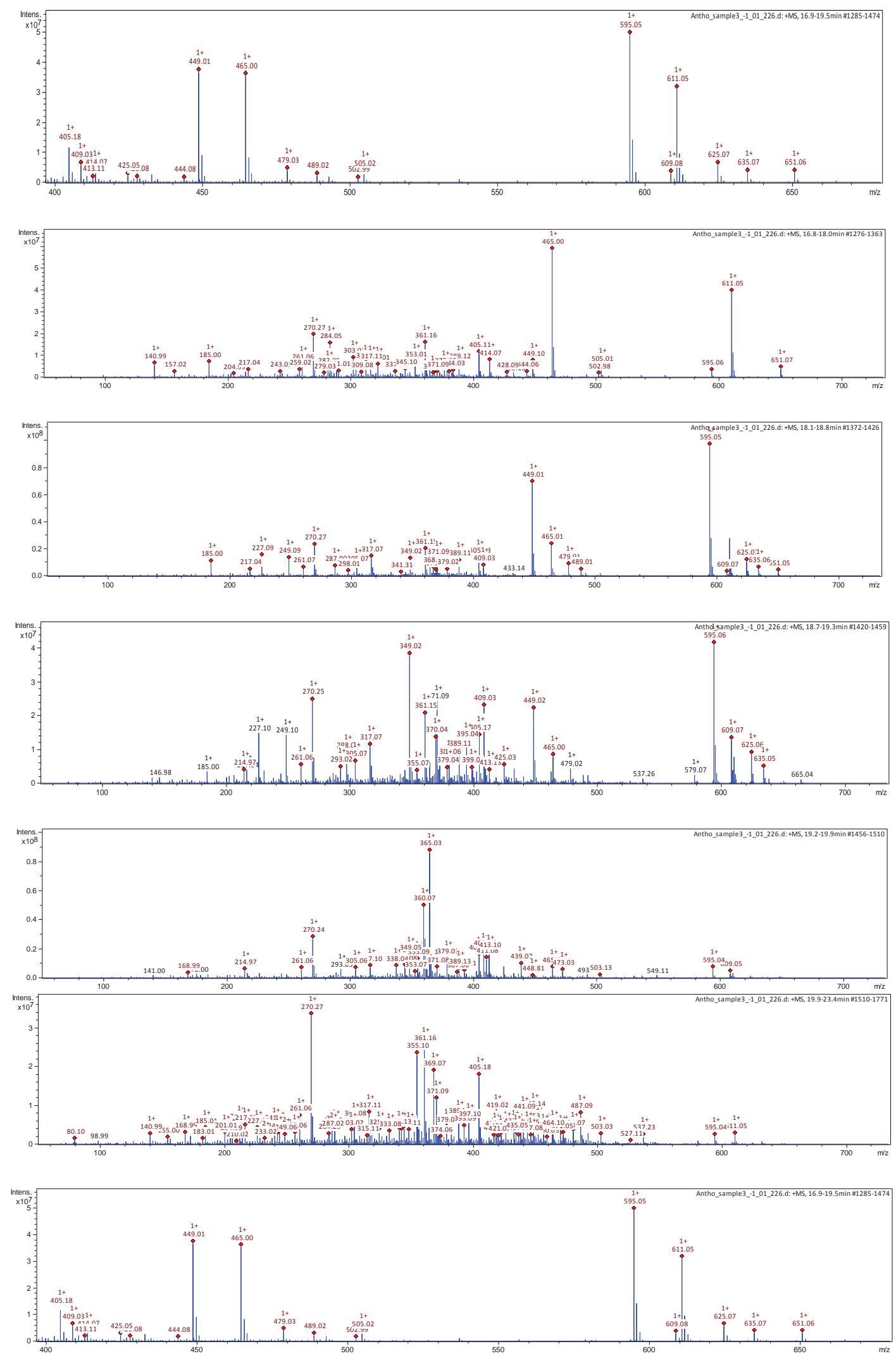

Puc. 3. Масс-спектр пиков антоцианидинов из образца 3 

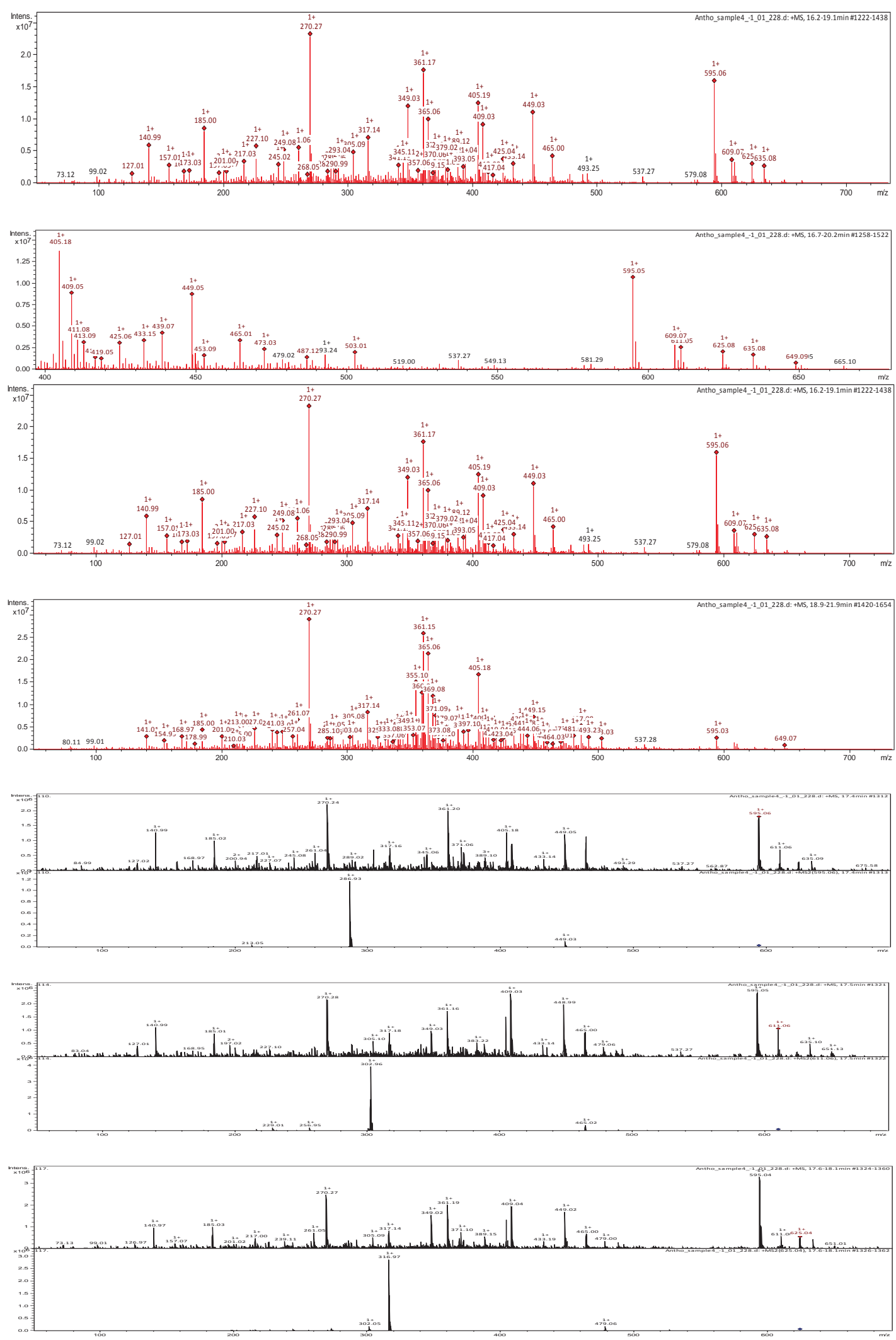

Puc. 4. Масс-спектр пиков антоцианидинов из образца 4 

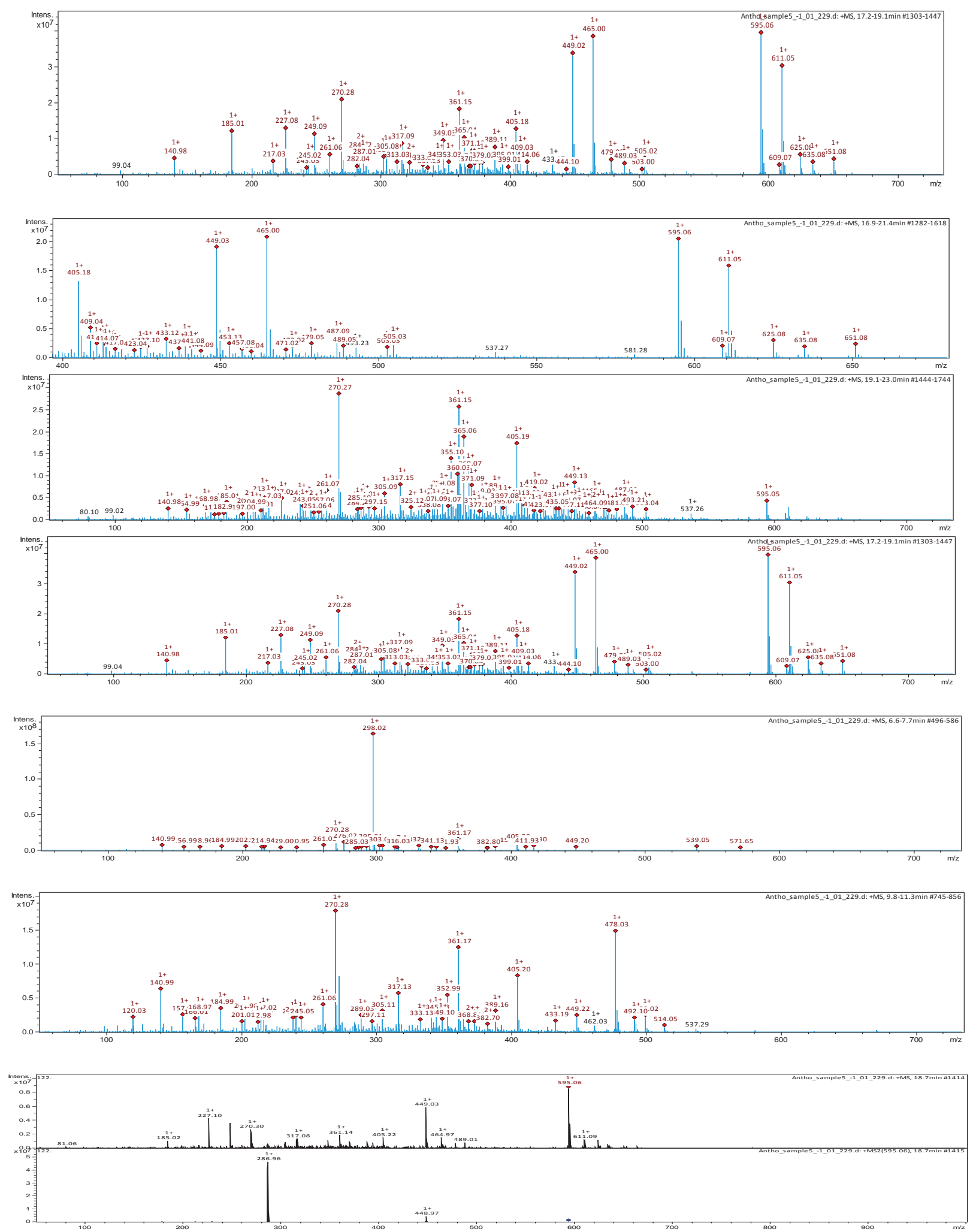

Puc. 5. Масс-спектр пиков антоцианидинов из образца 5 


\author{
Чеснокова Наталья Юрьевна, \\ Приходько Юрий Вадимович, \\ Каленик Татьяна Кузьминична
}

\title{
Антоцианы в пищевых технологиях и биотехнологиях
}

\author{
Подписано в печать 16.12.2021 г. \\ Формат 60×84 / 16. Усл. печ. л. 8,49. \\ Тираж 500 экз. (1-й завод 1-30). Заказ 311.
}

Дальневосточный федеральный университет

690922, Приморский край, г. Владивосток, о. Русский, п. Аякс, 10.

Отпечатано в Дальневосточном федеральном университете

690922, Приморский край, г. Владивосток, о. Русский, п. Аякс, 10.

(Типография Издательства ДВФУ,

690091, г. Владивосток, ул. Пушкинская, 10)

Chesnokova, N.Yu. Anthocyanins in food technology : monograph / N.Yu. Chesnokova, Yu.V. Prikhod'ko, T.K. Kalenik. - Vladivostok : Far Eastern Federal University Publishing House, 2021. - 146 p. : il. - ISBN 978-5-7444-5154-7.

For the first time the technologies for obtaining anthocyanin dyes from berries of the Far Eastern region and products of their processing - pomace with maximum extraction of anthocyanins and preservation of their pronounced biological activity - have been substantiated. Selected biosafety extractants - polysaccharides and proteins for the extraction of anthocyanins from berry raw materials, showed the feasibility and optimized conditions for the use of ultrasound, allowing to reduce the time and increase the completeness of the extraction of anthocyanins. Rational parameters of technologies of functional confectionery products using anthocyanin dyes containing complexes of biologically active substances have been scientifically substantiated. For the first time, the advantage of using complexes of anthocyanins and anionic polysaccharides for creating smart packaging has been shown.

The book is of interest primarily to workers in the food industry and food students of higher educational institutions.

Ill. 72, tabl. 39, bibl. 82.

Key words: berry raw materials of the Far Eastern region, anthocyanins, anthocyanin dye, complexes of anthocyanins and biopolymers, functional food, smart packaging. 